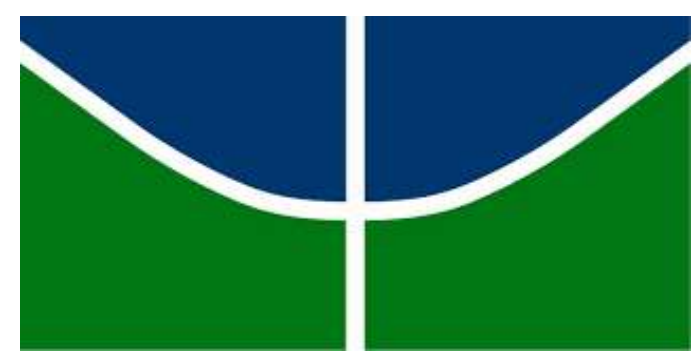

UNIVERSIDADE DE BRASÍLIA CENTRO DE ESTUDOS AVANÇADOS MULTIDISCIPLINARES PROGRAMA DE PÓS-GRADUAÇÃO EM DIREITOS HUMANOS E CIDADANIA

ÉRIKA LULA DE MEDEIROS

POR UMA PEDAGOGIA DA JUSTIÇA:

A experiência de extensão em direito e em direitos humanos do Escritório Popular do Motyrum da UFRN 


\section{ÉRIKA LULA DE MEDEIROS}

POR UMA PEDAGOGIA DA JUSTIÇA:

A experiência de extensão em direito e em direitos humanos do Escritório Popular do Motyrum da UFRN

Dissertação apresentada ao Programa de PósGraduação em Direitos Humanos e Cidadania do Centro de Estudos Avançados Multidisciplinares da Universidade de Brasília, sob orientação do professor doutor José Geraldo de Sousa Junior, como requisito para obtenção do título de Mestra em Direitos Humanos. Área de concentração: Interdisciplinar.

\section{Brasília}


POR UMA PEDAGOGIA DA JUSTIÇA:

A experiência de extensão em direito e em direitos humanos do Escritório Popular do Motyrum da UFRN

Dissertação apresentada ao Programa de Pós-Graduação em Direitos Humanos e Cidadania do Centro de Estudos Avançados Multidisciplinares da Universidade de Brasília, sob orientação do professor doutor José Geraldo de Sousa Junior, como requisito para obtenção do título de Mestra em Direitos Humanos. Área de concentração: Interdisciplinar.

\section{BANCA EXAMINADORA}

Presidente:

Prof. Dr. José Geraldo de Sousa Junior - PPGDH/CEAM, UnB, Brasil

1' Examinadora:

Prof ${ }^{-}$. Drå. Nair Heloísa Bicalho de Sousa - PPGDH/CEAM, UnB

2a Examinador:

Prof. Dr. José Humberto de Góes Júnior - UFG

Examinador suplente:

Prof. Dr. Gladstone Leonel da Silva Júnior - PPGDH/CEAM, UnB

Brasília, 12 de agosto de 2016

Resultado: 
Às brasileiras e aos brasileiros que neste momento histórico de golpe contra nossa jovem democracia, seguem resistindo e lutando, contra todas as formas de opressão. 


\section{AGRADECIMENTOS}

A caminhada percorrida até a finalização deste trabalho de pesquisa foi e é permeada de construções coletivas. Da extensão popular ao movimento estudantil, de Assessorias Jurídicas Universitárias Populares (AJUPs) a coletivos de mulheres, de reuniões coletivas de orientação a conversas cheias de trocas de ideias, perspectivas e afeto. Seria injusto esquecer algum nome entre tantas e tantos companheiros com quem tenho caminhado de mãos dadas. Por isso, agradecerei nominalmente a alguns coletivos, na certeza da compreensão de que representam muitas e muitos que deveriam estar aqui elencados.

Agradeço à Coordenação de Aperfeiçoamento de Pessoal de Nível Superior (CAPES), pelo apoio, durante quatro meses, a esta pesquisa.

Agradeço ao meu orientador, professor doutor José Geraldo de Sousa Junior, grande entusiasta deste trabalho, dos processos de luta potiguares, das possibilidades emancipatórias da universidade e da produção de conhecimento não-diletante, engajado com a transformação social. Meu agradecimento também pela trajetória de trinta anos construindo e compartilhando as ideias e ações de "O Direito Achado na Rua".

Agradeço à professora doutora Nair Heloísa Bicalho de Sousa e aos professores doutores Gladstone Leonel da Silva Junior e José Humberto de Góes Junior, pelas contribuições nas bancas de qualificação e de defesa desta dissertação. À professora Nair, em especial, pela aula de metodologia em ciências sociais que deu em suas considerações na qualificação e que permitiram uma pesquisa de campo mais rica. Aos professores e companheiros renapianos Glad e Betinho, por suas reflexões e práxis comprometidas com a luta popular e por suas contribuições extremamente relevantes e provocadoras.

Ao Programa de Pós-Graduação em Direitos Humanos e Cidadania (PPGDH), da Universidade de Brasília (UnB), experiência ousada e ainda recente no país de pesquisa interdisciplinar e com referencial crítico em direitos humanos, em especial à professora coordenadora Vanessa Maria de Castro, pela dedicação ao Programa e pela compreensão e sensibilidade fundamentais para conseguirmos concluir este trabalho.

Ao Escritório Popular do Motyrum da Universidade Federal do Rio Grande do Norte (UFRN), em especial às pessoas entrevistadas para esta pesquisa, Natália de Sena Alves, Natália Bonavides, Hélio Miguel Bezerra, Gustavo Barbosa, Magnus Marques, Daniel Pessoa, Lorena Cordeiro e Lucas Sidrim, por inspirarem tanto com 
as construções coletivas comprometidas com as lutas por direitos humanos na realidade potiguar.

À Rede Nacional de Advogadas e Advogados Populares (RENAP), que há 21 anos mobiliza, articula e forma advogadas e advogados engajados com a luta popular e promove encontros e possibilidades de atuações desde e com o direito comprometido com outro mundo possível.

Às Mariettas Badernas, coletivo de mulheres da Rede Nacional de Advogados e Advogadas Populares (RENAP), com quem tenho me encontrado nas diversas dimensões possíveis do verbo, desde 2011, e que têm sido grandes exemplos e formadoras, em especial Daniela Félix (SC), Luciana Ramos (AM/DF), Inez (MA), as Marianas Criolas Mari Trotta, Aninha, Fernanda e Aline (RJ), Marília Lomanto (BA), patrimônio da RENAP, Myllena (DF/BA), Lenir (RO), as Margaridas de Minas, em especial Lari e Layza (MG/PA), Lúcia Helena (RS) e Erina (PA/DF).

À Confederação do Equador, nossa seção nordestina da RENAP, em especial aos companheiros que nos acolheram e têm nos formado, Noaldo Meirelles, Edu Fernandes, Gustavo Magnata, Ludmilla Correia, Rodrigo Medeiros e Hugo Belarmino.

Ao "DhPh", com quem forjei coletivamente o projeto de vida como advogada popular, a Marcos Dionísio Mosquito, que me ensinou - e ensina - pelo exemplo a endurecer sem perder a ternura jamais, a Daniel Pessoa, às Natálias, Miguel e Gustavão, com quem compreendi o significado mais profundo de companheirismo.

Pela acolhida generosa e afetuosa em suas próprias casas que se fizeram lar para mim, a América Martins dos Santos, Laroca Ovídio, Mari Yokoya, Lu (Luciana Ramos) e Cobrinha (Ariadne Basílio), mulheres incríveis com quem aprendi e aprendo muito na partilha do cotidiano.

Às amigas incríveis da Vadiagem, Má, Babitz, Guá, Bel, Bru, Cissa, Julinha, Kil, Leilinha, Let, Melzinha, Nat e Thays, companheiras queridas que foram - e têm sido fundamentais para me sentir em casa neste cerrado, encontrando colo, afeto, diálogos e luta feminista.

Às ações extensionistas que permitiram meu "encharcamento de realidade" ao possibilitarem o encontro com os sujeitos historicamente oprimidos: ao Programa Motyrum de educação popular em direitos humanos (antigo Lições de Cidadania), ao Observatório da população infanto-juvenil em contextos de violência (OBIJUV), ambos da UFRN, à AJUP Roberto Lyra Filho, da UnB; e a todas e todos os companheiros com quem me encontrei nessas vivências. 
Aos movimentos sociais com quem pude me encontrar por meio da extensão universitária popular e da advocacia popular, em especial ao Movimento dos Trabalhadores e Trabalhadoras Sem-Terra (MST) e ao Movimento dos Trabalhadores e Trabalhadoras Sem-Teto (MTST), todo o meu respeito, admiração e agradecimento por alimentarem a crença no ser humano, na possibilidade de mudança, na justa-raiva potencializada em luta e ação transformadora.

Ao coletivo "Diálogos Lyrianos", materialização física dos debates e interlocuções desde O Direito Achado na Rua, onde pude me encontrar em diversas companheiras e companheiros, em diálogos, discussões, trocas e afetos.

Aos espaços profissionais e militantes que me acolheram nesse período de mestrado, o Centro de Defesa dos Direitos da Criança e do Adolescente (CEDECA/DF), a Terra de Direitos Organização de Direitos Humanos, a articulação Justiça e Direitos Humanos (JusDh) e o Projeto Ecoar: Protagonismo em Rede.

Às educadoras e educadores populares que pude conhecer por meio do mestrado ou do trabalho no Distrito Federal e que se tornaram grandes amigos, com quem aprendo muito sobre diálogo, alteridade, democracia e luta, em especial Andréia Crispim, Diego Mendonça e Calimério Junior.

Ao Instituto de Pesquisa Direitos e Movimentos Sociais (IPDMS), por assumir como desafio a construção de pesquisa militante e de debates que dialogam com a realidade social.

À segunda turma do PPGDH/UnB, por terem sido fundamentais para uma experiência tão rica como a do mestrado, por permitirem diálogos interdisciplinares e interlocução que bebe em outros saberes, pela cumplicidade dos aperreios com prazos e pela inspiração nos trabalhos comprometidos com uma perspectiva de libertação: Bruninha, Digs, Eliane, Fábio, Fred, Irina, Julinha, Lari, Pri, Raul, Vanessa, Vitor e Vivi.

Às demais turmas do PPGDH/UnB, em que encontrei grandes companheiras e companheiros que já se consolidam como interlocuções acadêmicas, afetos e amizades, em especial aos piauienses Andreia Marreiro e Lourival de Carvalho, e ao baiano Rogério Reis.

Às "Jasons" com quem dividi de conversas desde O Direito Achado na Rua até a casa, Helguinha, Cachinhos, Neto, Juan e Talita, meu agradecimento por todo o carinho e afeto do dia-a-dia. 
Às companheiras e companheiros com quem compartilhei inúmeros aprendizados, lutas e processos coletivos organizativos e desorganizativos na Esquerda Libertária Anticapitalista (ELA), em especial Mayra, Paraná, Candida e Telésforo Filho.

A Candida, uma das maiores entusiastas e incentivadoras deste trabalho, desde quando era uma ideia até a leitura e revisão, meu agradecimento por ter me apresentado ao OBIJUV, à pesquisa qualitativa, por ter compartilhado cotidiano, sonhos, lutas e amizades incríveis, a quem também agradeço por todo o amor: Keyla, Quel, Adriana, Sol, Rosa e dona Guiomar.

Às "amigas de Helene", em especial a Lívia, Pedro Lucas, Guga, Helene e Natas, por serem lugar de acolhida e respeito, de debates e de ternura, de diversão e leveza, de amor.

Ao professor Telésforo e à dra. Rosângela, meus pais, que pelo exemplo me arrastaram para a extensão universitária, para o diálogo e compromisso com o povo, para a militância política, para a pós-graduação, para a pesquisa comprometida com a realidade, para uma vida sem abrir mão de lutar por meus sonhos e pelo que acredito. Por todo o amor, por todo e cada diálogo, por tudo o que não cabe nestas linhas, meu agradecimento sincero e carinhoso.

Aos hermanos Étore e Telésforo Filho, por não se contentarem em nascerem irmãos e se forjarem assim pelo amor, pela partilha de diálogos, sonhos, lutas, pela acolhida incondicional e cuidadosa. A Étore, em especial, por ter aberto nossos caminhos pela extensão e movimento estudantil; a TF por ser um grande interlocutor deste trabalho e da vida e companheiro em tantas resistências.

Aos meus avôs Moacyr Medeiros e Mateus de Medeiros Lula, que não estão mais aqui, mas permanecem vivos em nós, e às minhas avós Edi Nóbrega de Medeiros e Bernadete Fernandes de Medeiros, por me ensinarem desde sempre a força, fibra e amor para as pequenas e grandes coisas da vida, pelos exemplos de honestidade, trabalho, dedicação a tudo o que fizeram e respeito ao povo sertanejo.

À Talita, pelo cotidiano de amor, cumplicidade e companheirismo, pelos diálogos e colos, pelas leituras atentas e revisão, pelas preocupações e cuidados, pela interlocução para a pesquisa e para a vida, pela paciência e persistência, por compartilhar sonhos e afeto, por ser chão e lar. 


\section{Canção Óbvia}

Escolhi a sombra desta árvore para repousar do muito que farei, enquanto esperarei por ti. Quem espera na pura espera vive um tempo de espera vã. Por isto, enquanto te espero trabalharei os campos e conversarei com os homens

Suarei meu corpo, que o sol queimará; minhas mãos ficarão calejadas; meus pés aprenderão o mistério dos caminhos; meus ouvidos ouvirão mais, meus olhos verão o que antes não viam, enquanto esperarei por ti.

Não te esperarei na pura espera porque o meu tempo de espera é um tempo de "quefazer". Desconfiarei daqueles que virão dizer-me, em voz baixa e precavidos:

É perigoso agir É perigoso falar É perigoso andar

É perigoso, esperar, na forma em que esperas, porquê êsses recusam a alegria de tua chegada. Desconfiarei também daqueles que virão dizer-me, com palavras fáceis, que já chegaste, porque êsses, ao anunciar-te ingênuamente , antes te denunciam. Estarei preparando a tua chegada como o jardineiro prepara o jardim para a rosa que se abrirá na primavera.

Paulo Freire, 1971.

Não me lamento, porque canto,

Faço do canto manifesto.

Sequei as águas do meu pranto Nos bronzes fortes do protesto. Acuso a puta sociedade, Com seus patrões, seus preconceitos.

O teto, o pão, a liberdade Não são favores, são direitos.

Noel Delamare, 1984 
MEDEIROS, Érika Lula de. POR UMA PEDAGOGIA DA JUSTIÇA: a experiência de extensão em direito e em direitos humanos do Escritório Popular do Motyrum da UFRN. 2016. 164 f., il. Dissertação (Mestrado em Direitos Humanos e Cidadania) Centro de Estudos Avançados Multidisciplinares, Universidade de Brasília, Brasília, 2016.

\section{RESUMO}

Analisa a função democratizante da justiça a partir da práxis do Escritório Popular do Programa Motyrum de Educação Popular em Direitos Humanos, ação extensionista desenvolvida na Universidade Federal do Rio Grande do Norte (UFRN). Desenvolve a hipótese de que existem elementos para uma Pedagogia da Justiça a partir do "quefazer" do Escritório Popular. Apresenta o programa de extensão universitária (Motyrum) em que se situa o projeto (EP) que é objeto da pesquisa. Descreve o desenho organizativo e institucional do EP. Identifica, sistematiza e apresenta as concepções de direito e de direitos humanos que balizam a atuação do EP, a partir de pesquisa empírica que realizou oito entrevistas, um grupo focal e análise documental. Analisa os aspectos da democratização e da pedagogia para a justiça a partir da práxis extensionista. Fundamenta a investigação desde o marco teórico de O Direito Achado na Rua e da teoria crítica de direito e de direitos humanos. Conclui que o EP se constitui como ponte entre a assessoria jurídica universitária popular (AJUP) e a advocacia popular, e cujo "quefazer" adquire contornos democratizantes para a justiça.

Palavras-chave: assessoria jurídica universitária popular. acesso à justiça. direitos humanos. extensão universitária. democratização da justiça. o direito achado na rua. pedagogia da justiça. 
MEDEIROS, Érika Lula de. HASTA UNA PEDAGOGIA DE LA JUSTICIA: la experiencia de extensión en derecho y en derechos humanos del Escritorio Popular do Motyrum de la UFRN. 2016. 164 f., il. Disertación (Maestría en Derechos Humanos y Ciudadanía) - Centro de Estudios Avanzados Multidisciplinares de la Universidad de Brasilia, Brasilia, 2016.

\section{RESUMEN}

Analiza la función democratizadora de la justicia desde la praxis del Escritorio Popular (EP) del Programa Motyrum de Educación Popular en Derechos Humanos, desarrollado en la Universidad Federal de Rio Grande do Norte (UFRN). Desarrolla la hipótesis de que existen elementos para una pedagogía de la justicia desde el "quehacer" del Escritorio Popular. Muestra el programa de extensión universitaria (Motyrum), donde se ubica el proyecto (EP) que es el objeto de investigación. Además, en él se describe el diseño organizativo e institucional de la EP. Identifica, sistematiza y presenta los conceptos de derecho y de derechos humanos que guían el trabajo del EP, desde la investigación empírica que llevó a cabo ocho entrevistas, un grupo de discusión y análisis de documentos. Examina los aspectos de la democratización y de la pedagogía de la justicia desde la praxis de extensión universitaria popular en investigación basada en el marco teórico de ODANR y la teoría crítica de la ley y los derechos humanos. Se llega a la conclusión de que el EP se constituye como un ponte entre la asesoría jurídica universitária popular (AJUP) y la abogacía popular, y cuyo "quehacer" suele democratizar la justicia.

Palabras clave: asesoría jurídica universitaria popular. acceso a la justicia. derechos humanos. extensión universitaria. democratización de la justicia. el derecho desde la calle. pedagogía de la justicia. 


\section{LISTA DE FIGURAS}

FIGURA 1: Núcleos (Projetos de extensão) do Programa Motyrum 40

FIGURA 2: Linha do tempo do Programa de educação popular em direitos humanos Lições de Cidadania, de seu surgimento até a mudança de nome para Motyrum 45

FIGURA 3: Organograma organizativo do "Lições de Cidadania" em 2007 49

FIGURA 4: Conflitos no campo no Brasil ............................................................... 72

FIGURA 5: Elementos geradores do Escritório Popular 75

FIGURA 6: Elementos provocadores da criação do Escritório Popular, presentes para além do contexto do $\mathrm{RN}$ 76

FIGURA 7: Categorização analítica dos sujeitos e critérios caracterizadores da atuação do EP 79

FIGURA 8: Linha do tempo do EP - Marcos estruturantes 98

FIGURA 9: Mapa com casos do EP (2010 - 2014) 104

FIGURA 10: Principal produção sobre Assessoria Jurídica Popular no Brasil 131 


\section{LISTA DE IMAGENS}

IMAGEM 1: Ação do Núcleo Urbano no Leningrado..................................... 43

IMAGEM 2: Ação do Núcleo Rural............................................................ 44

IMAGEM 3: Ação do Núcleo Indígena ............................................................ 44

IMAGEM 4: Ação do EJUPIn ................................................................. 53

IMAGEM 5: Acampamento do MST queimado em Touros/RN ........................ 105

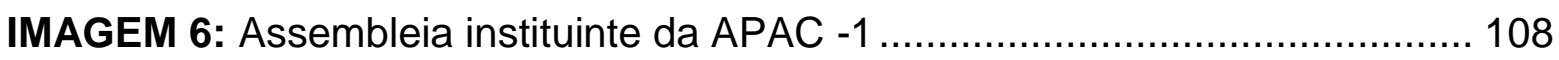

IMAGEM 7: Assembleia instituinte da APAC -2 ......................................... 109

IMAGEM 8: Coletiva de imprensa da comissão jurídica durante a ocupação da câmara municipal de natal pelo movimento Fora Micarla 110 


\section{LISTA DE ABREVIATURAS E SIGLAS}

AATR Associação de Advogados de Trabalhadores Rurais no Estado da Bahia AJP Assessoria Jurídica Popular

AJUP Assessoria Jurídica Universitária Popular

ANAP Associação Nacional de Advogados das Lutas Populares

APAC Associação Potiguar dos Atingidos pela Copa de 2014

CAAC Centro Acadêmico Amaro Cavalcanti

CCET Centro de Ciências Exatas e da Terra

CEAM Centro de Estudos Avançados Multidisciplinares

CEBRAP Centro Brasileiro de Análise e Planejamento

CEDECA Centro de Defesa dos Direitos da Criança e do Adolescente

CEJUS Centro de Estudos sobre o Sistema de Justiça

CES/AL Centro de Estudos Sociais América Latina

CONSEPE Conselho de Ensino, Pesquisa e Extensão

CPT Comissão Pastoral da Terra

$\mathrm{CRDH} \quad$ Centro de Referência em Direitos Humanos

CRUTAC Centro Rural Universitário de Treinamento e Ação Comunitária

EJA Educação de Jovens e Adultos

EJUPIn Educação Jurídica Popular Infantil

ENEDEx Encontro Nacional de Estudantes de Direito Extensionistas

EP Escritório Popular

FORPROEX Fórum de Pró-Reitores de Extensão das Universidades Públicas Brasileiras

IAJUP Instituto de Apoio Jurídico Popular

IBGE Instituto Brasileiro de Geografia e Estatísticas

IES Instituição de Ensino Superior

IPDMS Instituto de Pesquisa Direitos e Movimentos Sociais

JusDH Articulação Justiça e Direitos Humanos

MEC Ministério da Educação

MJ Ministério da Justiça

MLB Movimento de Luta nos Bairros, Vilas e Favelas

MOBRAL Movimento Brasileiro de Alfabetização

Motyrum Programa Motyrum de Educação Popular em Direitos Humanos 


$\begin{array}{ll}\text { MPA } & \text { Movimento de Pequenos Agricultores } \\ \text { MPMG } & \text { Ministério Público do Estado de Minas Gerais } \\ \text { MST } & \text { Movimento Sem Terra } \\ \text { NAIR } & \text { Nova Escola Jurídica brasileira } \\ \text { NPJ } & \text { Núcleo de Prática Jurídica } \\ \text { OBIJUV } & \text { Observatório da População Infanto-Juvenil em Contextos de Violência } \\ \text { ODANR } & \text { O Direito Achado na Rua } \\ \text { OJB } & \text { Observatório da Justiça Brasileira } \\ \text { PEGADAS } & \text { Projetos de Engenharia e Gestão aplicados ao Desenvolvimento } \\ & \text { Ambiental e Social } \\ \text { PNUD } & \text { Programa das Nações Unidas para o Desenvolvimento } \\ \text { PPGDH } & \text { Programa de Pós-Graduação em Direitos Humanos e Cidadania } \\ \text { PROEX } & \text { Pró-Reitoria de Extensão } \\ \text { PROEXT } & \text { Programa de Extensão Universitária } \\ \text { PRONERA } & \text { Programa Nacional de Educação na Reforma Agrária } \\ \text { QDA-Miner } & \text { Qualitative Data Analysis Software } \\ \text { REMAR } & \text { Renovação Marista } \\ \text { RENAJU } & \text { Rede Nacional de Assessorias Jurídicas Universitárias } \\ \text { RENAP } & \text { Rede Nacional de Advogados e Advogadas Populares } \\ \text { RN } & \text { Estado do Rio Grande do Norte } \\ \text { SAJU } & \text { Serviço de Apoio Jurídico e/ou Serviço de Assessoria Jurídica } \\ & \text { Universitária } \\ \text { SDH/PR } & \text { Secretaria de Direitos Humanos da Presidência da República } \\ \text { SOI } & \text { Simulação de Organizações Internacionais } \\ \text { SRJ } & \text { Secretaria de Reforma do Judiciário } \\ \text { UERN } & \text { Universidade Estadual do Rio Grande do Norte } \\ \text { UFBA } & \text { Universidade Federal da Bahia } \\ \text { UFERSA } & \text { Universidade Federal Rural do Semi-Árido } \\ \text { UFMG } & \text { Universidade Federal de Minas Gerais } \\ \text { UFRGS } & \text { Universidade Federal do Rio Grande do Sul } \\ \text { UFRN } & \text { Universidade Federal do Rio Grande do Norte } \\ \text { UnBCar } & \text { Universidade Federal de São Carlos } \\ \text { Universidade de Brasília }\end{array}$


SUMÁRIO

PRIMEIRAS PALAVRAS 16

CAPÍTULO 1 DAS LIÇÕES DE CIDADANIA AO MOTYRUM: O CAMINHO SE FAZ CAMINHANDO

1.1. Conhecer, despertar, dialogar, avaliar e celebrar: o Programa Motyrum de educação popular em direitos humanos. 38

1.2. O Lições de Cidadania

CAPÍTULO 20 "QUEFAZER” DO ESCRITÓRIO POPULAR: uma experiência de extensão universitária em direito e em direitos humanos 66

2.1. Localizando no tempo-espaço: a caminhada do Escritório Popular 68

2.1.1. Montando um quebra-cabeças: juntando as peças que formaram o Escritório Popular 69

2.2. Da concepção popular que permeia o "quefazer": de sem-direitos e oprimidos a sujeitos coletivos de direito .78 2.3. Escritório Popular: uma ponte entre a extensão universitária e a advocacia popular

CAPÍtUlO 3 POR UMA PEDAGOGIA DA JUSTIÇA: A FUNÇÃo DEMOCRATIZANTE DO ESCRITÓRIO POPULAR...........................................119

3.1. A dimensão pedagógica como função democratizante ..............................123

3.2. Uma experiência de Assessoria Jurídica Universitária Popular ................130

3.3. Direito e direitos humanos na fala e voz extensionista .............................134

CONSIDERAÇÕES FINAIS 140 
ANEXOS

ANEXO A - NOTA DO PROGRAMA MOTYRUM SOBRE A MUDANÇA DE NOME ........ ANEXO B - ROTEIRO DE PERGUNTAS UTILIZADO PARA AS ENTREVISTAS............. ANEXO C - ROTEIRO UTILIZADO PARA O GRUPO FOCAL

ANEXO D - ESTATUTO DO LIÇÕES DE CIDADANIA DE 2007. 


\title{
PRIMEIRAS PALAVRAS
}

\begin{abstract}
O Brasil sempre foi, ainda é, um moinho de gastar gentes. Construímo-nos queimando milhões de índios. Depois, queimamos milhões de negros. Atualmente, estamos queimando, desgastando milhões de mestiços brasileiros, na produção não do que eles consomem, mas do que dá lucro às classes empresariais. (RIBEIRO, 2010, p.25).
\end{abstract}

Aos esfarrapados do mundo e aos que neles se descobrem e, assim descobrindo-se, com eles sofrem, mas, sobretudo, com eles lutam. (FREIRE, 2012)

A pesquisa acadêmica desenvolvida teve como objetivo geral analisar a função democratizante da justiça. Para tanto, lançamos um olhar sobre a práxis ${ }^{1}$ do Escritório Popular (EP) do Programa Motyrum² de Educação Popular em Direitos Humanos (Motyrum) ${ }^{3}$, ação extensionista desenvolvida na Universidade Federal do Rio Grande do Norte (UFRN) e que realiza educação popular em direitos humanos junto a sujeitos coletivos de direito ${ }^{4}$ do estado.

O EP surge da práxis extensionista do Motyrum e é constituído como resposta criativa às limitações do Núcleo de Prática Jurídica da UFRN (NPJ/UFRN) para lidar com demandas coletivas das comunidades em que o Motyrum atuava. É criado, assim, em diálogo com as demandas concretas desses grupos. Antecipando alguns dos resultados da pesquisa, situamos o EP como experiência extensionista que se constitui

\footnotetext{
1 O conceito de práxis empregado é o defendido por Adolfo Sánchez Vásquez em sua obra "Filosofia da Práxis": "Partindo da concepção de Marx, entendemos a práxis como atividade material humana transformadora do mundo e do próprio homem. Essa atividade real, objetiva, é, ao mesmo tempo, ideal, subjetiva e consciente". (SÁNCHEZ VÁSQUEZ, 2011, p.398).

2 O título do programa de extensão será objeto de análise no primeiro capítulo. Conferir o Manifesto que consta no Anexo A - Nota do programa Motyrum sobre a mudança de nome, desta dissertação.

3 Doravante utilizaremos a palavra "Motyrum" para designar o Programa de Extensão, como um todo, e a expressão "EP" para a designação da atuação do projeto extensionista específico.

${ }^{4} \mathrm{~A}$ categoria de sujeito coletivo de direitos será tratada no capé adotada no sentido formulado e proposto por José Geraldo de Sousa Junior. Ao analisar a "[...] atuação jurídica dos novos sujeitos coletivos e das experiências por eles desenvolvidas de criação de direito [...]" (SOUSA JUNIOR, 2008, p.145), o autor compreende que "A categoria 'sujeito coletivo de direito', deduzida da análise das experiências sociais de criação de direitos, inscreve-se nesse programa [de O Direito Achado na Rua] e é configurada agora, como objeto de construção teórica no esforço desse projeto. A partir da constatação derivada dos estudos acerca dos chamados novos movimentos sociais, desenvolveu-se a percepção, primeiramente elaborada pela literatura sociológica, de que o conjunto das formas de mobilização e organização das classes populares e das configurações de classes constituídas nesses movimentos instaurava, efetivamente, práticas políticos novas em condições de abrir espaços sociais inéditos e de revelar novos atores na cena política capazes de criar direitos." (SOUSA JUNIOR, 2008, p.146).
} 
como ponte entre a assessoria jurídica universitária popular (AJUP) e a advocacia popular, e cujo "quefazer"5 adquire contornos democratizantes para a justiça.

O texto dissertativo sintetiza e sistematiza os principais dados, análises e informações obtidos a partir de pesquisa empírica realizada no âmbito do Programa de Pós-Graduação em Direitos Humanos e Cidadania no período de 2013 a 2016, e que foi desenvolvida à luz do marco teórico de "O Direito Achado na Rua" (ODANR) .

A dissertação está organizada em três capítulos, além deste texto introdutório, das considerações finais, das referências bibliográficas e anexos encartados ao final.

No primeiro capítulo, apresentamos o programa de extensão universitária (Motyrum) em que se situa o projeto (EP) que é objeto de análise desta pesquisa. Optamos por descrevê-lo resgatando sua historicidade por entendermos que olhar para sua trajetória e suas escolhas possibilita o desvelamento de elementos estruturantes para a práxis de uma extensão que se pretende popular e para o desenvolvimento de processos de educação popular em direitos humanos.

Já no segundo capítulo, desenvolvemos prioritariamente o segundo objetivo específico desta pesquisa: a descrição do desenho organizativo e institucional do EP. A interlocução entre a práxis do projeto, as categorias teóricas que perpassam sua dimensão pedagógica e as oito entrevistas realizadas com integrantes do EP e que foram executadas em pesquisa de campo, é constante ao longo de todo o capítulo. Na centralidade do capítulo estão as análises relacionadas aos sujeitos com quem o EP atua e que o adjetiva como popular e a construção de uma linha do tempo para o projeto, fruto da sistematização do trabalho de campo e análise documental desta pesquisa. O terceiro e último capítulo propõe-se a investigar as concepções de direito e de direitos humanos que balizam a atuação do EP, bem como a analisar a dimensão

\footnotetext{
5 "Mas, se os homens são seres do "quefazer" é exatamente porque seu fazer é ação e reflexão. É práxis. É transformação do mundo. E, na razão mesma em que o "quefazer" é práxis, todo fazer do "quefazer" tem de ter uma teoria que necessariamente o ilumine. O "quefazer" é teoria e prática. É reflexão e ação." (FREIRE, 2012, p. 131)

6 A pesquisa considera o político-pedagógico ODANR como escola de pensamento jurídico, no marco da Nova Escola Jurídica brasileira (NAIR). Roberto Lyra Filho, em obra originalmente publicad em 1982, explica a NAIR como sendo "[...] humanismo, porém dialético, e este há de ser entendido, como lembrava Agosti, no sentido de 'historicidade dialética da liberdade em seu avanço sobre a necessidade'; isto é, 'humanismo real', que não morreu numa fase, mas ainda vem iluminar toda luta pelo Direito. O seu princípio supremo inscreve-se na própria matriz declaratória dos Direitos do Homem Socialista, e é nestes termos que o esposamos: 'o livre desenvolvimento de cada um é condição para o livre desenvolvimento de todos'. A partir daí é que se efetua a conscientização e libertação, nas quais constantemente se repropõe e redefine o padrão justo, concreto e atual da coexistência da liberdade. Assim é que nós, da Nova Escola Jurídica Brasileira, vemos o Direito na sua 'essência', modelo e finalidade. Tudo o mais - escrevi num livro recente - ou é consequência a determinar (pelo Homem, para o Homem, com os Homens, no impulso ascendente e de vanguarda dentro do itinerário evolutivo), ou é deturpação do Direito, a combater como obstáculo ao progresso da Humanidade." (LYRA FILHO, 2003, p.15, grifos do autor).
} 
pedagógica como principal contribuição democratizante do projeto para a justiça - daí a conclusão de que seu "quefazer" elenca elementos para uma Pedagogia da Justiça. Para isso, realiza uma análise desde o marco teórico de ODANR e sua perspectiva crítica de direito e de direitos humanos, bem como do marco sobre as AJUPs, sempre num esforço de diálogo com as falas das pessoas entrevistadas.

Por fim, são apresentadas as considerações finais que apontam na direção da hipótese inicial desta dissertação, de que o quefazer do EPapresenta elementos para uma pedagogia da justiça, na medida em que sua práxis provoca um deslocamento das concepções de direito e de direitos humanos nas e nos extensionistas, de forma que o EP se constitui como um ator para a democratização da justiça na realidade potiguar.

Para compreender o EP e a dimensão democratizante para a justiça a que referimos, é necessário resgatar o contexto que ensejou o desenvolvimento da pesquisa, bem como delimitar o escopo teórico-político que subjaz a sua realização.

No Brasil, país de milhões de sem-terra, sem-teto, "sem-direitos"7 e grupos historicamente dominados, explorados e excluídos, é imprescindível que superemos a estreiteza da compreensão formal dos direitos humanos e passemos à reflexão e pesquisa sobre estratégias para sua materialização cidadã.

Os direitos não nascem de textos, nem é neles que se garantem. "Os lírios não nascem da lei", dizia Carlos Drummond de Andrade ${ }^{8}$. Os homens - e as mulheres pedem carne. Fogo. Sapatos. Moradia. Lazer. Igualdade. Liberdade. Respeito.

Não desconsideramos o papel que a positivação de direitos em normas constitucionais, internacionais ou ordinárias pode desempenhar como parte de um processo de luta e conquista de cidadania. O problema fundamental não é simplesmente dar efetividade às normas estatais garantidoras de direitos, como se seu conteúdo estivesse definido em abstrato pelo próprio texto e bastassem competência técnica e "vontade política" aos poderes estatais para implementá-las. A questão que nos desafia é compreender as práticas, os sujeitos e os processos sociais que

\footnotetext{
${ }^{7}$ Abordaremos a categoria dos "sem-direitos", tal como formulada por Enrique Dussel (2001), no capítulo 2.

8 "Em vão percorremos volumes, / viajamos e nos colorimos. / A hora pressentida esmigalha-se em pó na rua. / Os homens pedem carne. Fogo. Sapatos. / As leis não bastam. Os lírios não nascem / da lei. Meu nome é tumulto, e escreve-se / na pedra." (ANDRADE,1945).
} 
constroem os direitos humanos, tanto no seu plano cognitivo como na sua dimensão pragmática de realização concreta 9 .

Pesquisar a construção dos direitos humanos exige, portanto, que voltemos os olhos para o seu nascedouro social: para os "sujeitos coletivos" que os enunciam e lutam pelos seus sentidos e sua concretização (SOUSA JUNIOR, 1999), e para os processos de direitos que "vem incorporar a compreensão de que os direitos se constroem e se desconstroem na medida dos contextos de desenvolvimento político e social de cada sociedade, em sua própria história" (ESCRIVÃO FILHO; SOUSA JUNIOR, 2015, p. 45).

Nesse sentido, dentre as possibilidades de construir e usar o direito como instrumento de emancipação dos sem-direitos, é que se localizam experiências de extensão popular em direito e em direitos humanos como as assessorias jurídicas universitárias populares (AJUP). São experiências desenvolvidas na perspectiva de atuar com a ampla parcela da população oprimida para garantir seu acesso à justiça, pautando sua democratização de fato e, ainda, de agir no processo de formação de profissionais de diversas áreas que terão sua atuação na esfera da promoção, proteção e garantia de direitos. Nas palavras de Boaventura de Sousa Santos, é necessário "democratizar a democracia" (SANTOS, 2002). A organização e emancipação dos movimentos de sem-direitos para enunciar e conquistar direitos humanos para si mesmos é condição para a democratização da justiça.

De acordo com esse entendimento, pelo menos desde o período de luta contra a ditadura civil-militar de 1964-85, vêm se formando em todo o país grupos de assessorias jurídicas populares (GOSDORF, 2010, p. 7; CARLET, 2010, p. 28 e seguintes; SÁ E SILVA, 2010, p. 340). São projetos que atuam através da assessoria a movimentos populares, sindicatos ou organizações não-governamentais, sempre ligadas à temática dos direitos humanos (MAIA, 2007).

Dentro dessa perspectiva, como uma alternativa à prática jurídica tradicional, demonstrando que é possível operar o direito em uma perspectiva emancipatória e transformadora (MAIA, 2007), têm nascido no âmbito de cursos de direito de

\footnotetext{
${ }^{9}$ Por plano cognitivo e dimensão pragmática nos referimos, respectivamente, à semântica e à pragmática dos direitos humanos, tal como desenvolvida pelo jusfilósofo Joaquín Herrera Flores. O autor formula, em sua teoria crítica dos direitos humanos, uma proposta esquemática para explicação da complexidade dos direitos humanos que é caracterizada como um "diamante ético sintaxe da realidade dos direitos humanos" (HERRERA FLORES, Joaquim. A re-invenção dos direitos humanos. Florianópolis: Boiteaux, 2009. p.122), que é derivado do entrecruzamento de duas coordenadas (eixos vertical e horizontal) que contém os elementos conceitual e material de onde se situa a ideia de dignidade humana. A proposta do jusfilósofo é integrar a semântica e a pragmática dos direitos humanos para a sua compreensão.
} 
universidades públicas e privadas do Brasil projetos de extensão com esse viés, as AJUPs. Diante desse contexto de violações sistemáticas de direitos, de necessidade de processos de democratização da justiça e de atuação de AJUPs, cabe perguntar: em que medida esses núcleos de AJP têm conseguido se constituir como atores democratizantes para a justiça?

A práxis sócio-política revela que o direito nasce das lutas sociais, do desejo permanente de libertação (SANT'ANNA, 1987, p.31), e que é, portanto, necessário libertar os direitos humanos da jaula de ferro em que foram encarcerados pela ideologia de mercado e sua legitimação jurídica formalista e abstrata (HERRERA FLORES, 2009, p.23). Sistematizar, estudar e formular teoricamente sobre experiências de extensão universitária como núcleos de AJUPs é potencializar tal perspectiva emancipatória.

A pesquisa realizada sobre o EP constitui trabalho acadêmico sobre a práxis dos e das que "com eles [oprimidos] lutam" (FREIRE, 2012) e que nasceu motivado por três fatores principais, reveladores também do lugar de fala da pesquisadora:

a) o encontro da pesquisadora, em sua trajetória acadêmica, pessoal, humanística e profissional com movimentos sociais e a consequente escolha e construção de um projeto de vida embrenhado na advocacia popular;

b) a oportunidade da pesquisa e pesquisadora contribuírem para ampliar a visibilidade sobre a região do Nordeste brasileiro; e

c) a possibilidade de refletir teoricamente sobre a democratização da justiça desde uma perspectiva dialética social que considera e é construída a partir da relação estabelecida entre a ação e a reflexão.

Para melhor compreender cada um desses fatores que justificam e delimitam o tema da pesquisa, passo a evidenciá-los e problematizá-los em primeira pessoa.

O primeiro fator (a) a ser analisado dialoga diretamente com a trajetória percorrida e projeto de vida que encampei. Durante o período de minha graduação em direito (2006 a 2011) - e de vivência universitária (2003 - atual) de forma mais ampla busquei conhecer e construir diferentes projetos de pesquisa e de extensão. Experiências estas que contribuíram para que eu pudesse expandir meus horizontes sobre as formas de conhecimento e a existência de outros saberes, para além dos limites que acabam sendo colocados no âmbito do ensino em direito (aulas teóricoexpositivas e conhecimento dogmático e sistemático emergido de compêndios, manuais, códigos e leis). Nesse sentido, tive a oportunidade e curiosidade de aproximar-me do OBIJUV (2011-2012), da SOI (2006-2008) e, finalmente, do "Lições de 
Cidadania" (2010-2011) que, posteriormente, seria renovado para constituir o Motyrum. Nessas últimas ações extensionistas (Lições e Motyrum) colaborei, diretamente, nas atividades do "Núcleo Urbano" (2010-2011) e na fundação do "EP" (2010). Foi nessa práxis extensionista que ocorreu o meu primeiro encontro com movimentos sociais. $\mathrm{E}$ foi nesse encontro propiciado pela práxis extensionista que me encontrei com a advocacia popular, assumindo-a como projeto de vida. Foi, portanto, nesse "quefazer" extensionista que me encontrei com os sujeitos "sem-direitos" (DUSSEL, 2001) e os "esfarrapados do mundo" (FREIRE, 2012), e foi, justamente, provocada por ele(s) que me encontrei, também, com a Rede Nacional de Advogados e Advogadas Populares (RENAP) e com O Direito Achado na Rua (ODANR), ambas referências que, desde então, me acompanham. Foi, portanto, essa práxis extensionista que me revelou "com quem" (os movimentos sociais) e "como" (assessoria jurídica popular) "caminhar", e viabilizou o alargamento de minha compreensão sobre o direito, os direitos humanos, 0 acesso à justiça e os desafios colocados à democracia no Brasil.

O segundo fator (b) que considero relevante para a justificativa e delimitação da pesquisa refere-se à possibilidade de dar oportunidade de visibilidade para uma experiência do e no Nordeste brasileiro, local que, a nosso ver, configura um lócus e práxis de resistência e de luta por direitos. Destaco que no momento inicial de desenvolvimento desta pesquisa, que coincide com o ingresso no Programa de PósGraduação em Direitos Humanos e Cidadania (PPGDH) do Centro de Estudos Avançados Multidisciplinares (CEAM) da Universidade de Brasília (UnB), cogitei realizar um estudo de caso sobre a experiência extensionista da AJUP "Roberto Lyra Filho", projeto de assessoria jurídica universitária popular (AJUP) desenvolvido no Distrito Federal, na UnB, e da qual participo desde sua fundação, em 2012. Esse estudo, se realizado, consistiria na primeira investigação e análise sobre referida experiência extensionista, e, muito provavelmente, seria uma pesquisa mais prática de ser executada, pois coincidiria geograficamente com o local em que atualmente habito.

Porém, decidi assumir a perspectiva de que a pesquisa também é uma oportunidade de dar visibilidade para uma experiência nordestina. Considerando que o Nordeste é a região mais pobre do Brasil (IBGE, 2011; PNUD, 2013) e que as regiões mais ricas do país (Sul e Sudeste) acabam tendo maior destaque e expressividade nacional no que se refere à produção do conhecimento - devido à possibilidade de maior captação de recursos e difusão de experiências que é propiciado pelo acúmulo 
de capital político e econômico no sul-sudeste -, a oportunidade de destacar a atuação contra-hegemônica do EP no RN e, de forma mais ampla, na democratização da justiça constituiu fator decisivo para a escolha do caso a ser estudado. Consideramos, portanto, que, de outra forma, a experiência do EP seria invisibilizada por outras vivências que, embora importantes, sufocá-la-iam em razão do capital acumulado e não, necessariamente, pela inovação que representariam. Além disso, a criação de um núcleo de assessoria jurídica universitária popular que se propõe a atuar com conflitos sociais da realidade potiguar pode se constituir como experiência relevante de resistência a violações de direitos.

A pesquisa adota como uma de suas hipóteses problematizadoras a ideia de que o projeto do EP, de alguma forma, integra uma estratégia de resistência contextualizada, na medida em que escolhe caminhar com os grupos "sem-direitos", com os movimentos sociais e com os grupos historicamente oprimidos, e, portanto, soma-se à resistência do povo na luta pelo reconhecimento e garantia de seus direitos e justiça. Aliás, nesse sentido, é de se frisar, antecipando alguns achados da pesquisa, o impacto da atuação do EP na realidade do estado do Rio Grande do Norte, tendo se constituído, em cinco anos de atuação extensionista, em referência no que tange à luta por direitos humanos no estado.

Também consideramos que é muito reduzido o campo de pesquisas, principalmente as que adotam métodos empíricos (o uso de metodologias de abordagem empírica e qualitativa no campo do direito e dos direitos humanos ainda é muito reduzido), relacionadas à AJUP - e AJP de maneira geral - no país, e dentro delas, mais reduzidas ainda àquelas que enfocam experiências do Norte e Nordeste brasileiros. Essas considerações e contextos enunciados, quando colocados em uma perspectiva histórica da extensão no Brasil, ganham novos contornos: o Rio Grande do Norte foi berço de trabalhos emblemáticos de Paulo Freire (o mais famoso, talvez, seja aquele em que o pedagogo alfabetizou, em quarenta e cinco dias, mais de trezentos trabalhadores canavieiros $^{10}$ ) e berço, ainda, da própria concepção e estruturação da extensão no Brasil

\footnotetext{
${ }^{10}$ A primeira experiência de alfabetização em que Paulo Freire aplicou o seu método foi realizada em Recife, em um círculo de cultura do Movimento Cultural Popular do Recife. Posteriormente, houve a experiência em Angicos, no RN, em que 300 trabalhadores foram alfabetizados em 45 dias. A partir dessa experiência, João Goulart convidou Paulo Freire para organizar uma Campanha Nacional de Alfabetização, que contaria com a organização de vinte mil círculos de cultura, em diferentes localidades do Brasil, com o objetivo de alfabetizar dois milhões de pessoas. O Golpe Militar interrompeu essa experiência, e a estratégia adotada, a partir de então, foi a do Movimento Brasileiro de Alfabetização (MOBRAL), cuja proposta de ensino da leitura e da escrita foge aos escopos humanísticos e dialógicos freireanos. Conferir: FREIRE, 2001; e BRANDÃO, 1981.
} 
(Programa Centro Rural Universitário de Treinamento e Ação Comunitária - CRUTAC ${ }^{11}$ ), além de ser a terra na qual originaram-se importantes lideranças populares e sindicais.

O terceiro fator (c) que incidiu sobre a justificação e delimitação do tema e da pesquisa foi a possibilidade de refletirmos teoricamente a democratização da justiça sobre e a partir de ODANR. Nosso local acadêmico e institucional de fala está situado no PPGDH/UnB, na linha de pesquisa "direitos humanos, democracia, construção de identidades/ diversidades e movimentos sociais", e no grupo de pesquisa ODANR, da UnB. Essa localização possibilitou dialogarmos e abordarmos o estudo de caso a partir do marco de ODANR, referencial teórico adotado pelo Motyrum e EP, conforme detalharemos ao longo do trabalho. Por fim, porque viemos de uma caminhada de práxis, de atuação extensionista, e sentimos a necessidade de refletirmos teoricamente sobre essa experiência e expressão universitária, em um movimento de ação e reflexão que nos guia desde a extensão.

Tendo como referências referidos fatores de justificação e delimitação, desenvolvemos a pesquisa realizando um estudo de caso sobre o EP que aborda qualitativamente uma práxis extensionista em direito e direitos humanos localizada no município de Natal, capital do Estado do Rio Grande do Norte, no nordeste brasileiro, e analisa elementos reveladores daquilo que denominarei como constituinte de uma potencial "pedagogia da justiça".

É essa análise sobre a pedagogia da justiça que caracteriza o objetivo geral da pesquisa. Categoria de análise de inspiração freireana e que se apresenta inovadora para o campo do direito e inédita nas áreas das ciências sociais e humanas.

A sistematização da experiência extensionista revelou-se como um desafio e ao mesmo tempo como demanda elencada pelas pessoas entrevistadas na etapa do campo. Assim, a fim de garantir o desenvolvimento do trabalho em diálogo com as e os extensionistas entrevistados e sem perder de vistas o recorte pretendido de estudar o EP pensando em suas contribuições para a democratização da justiça,

\footnotetext{
11 Destacamos que apresentamos uma perspectiva crítica à concepção de extensão estruturada a partir do CRUTAC no Brasil. A nosso ver, não foi à toa que o primeiro Centro Rural Universitário de Treinamento e Ação Comunitária do país foi no RN, tendo em vista a influência de Paulo Freire a partir dos processos exitosos no estado, com experiências como a de Angicos e a proposta da campanha "De Pé no Chão também se aprende a ler" - esta foi projeto da gestão do prefeito Djalma Maranhão na capital potiguar (1960-1964), cujo objetivo era usar o método Paulo Freire para reduzir o alto índice de analfabetismo na cidade, o que foi interrompido pelo golpe civil-militar. Assim, o CRUTAC foi criado logo no início da ditadura civil-militar brasileira (1965) justamente contrapondose à concepção freireana de um processo educativo comprometido com a libertação e emancipação popular e tendo como "seus objetivos o foco da manutenção da ordem e segurança nacional" (SERRANO, 2011, p.8). Conferir: GONÇALVES; VIERIA, 2015 e SERRANO, 2011.
} 
identificando elementos para uma pedagogia da justiça, desenvolvemos os seguintes objetivos específicos: (a) apresentar o Programa Motyrum de educação popular em direitos humanos, a partir da construção de uma linha do tempo com elementos que permitem provocar discussões sobre extensão universitária e educação em direitos humanos; (b) descrever o desenho institucional do EP a partir de sua inserção na UFRN e reconhecendo-o como uma ponte entre a assessoria jurídica universitária popular e a advocacia popular; (c) investigar as concepções de direito e de direitos humanos que balizam a atuação do EP, identificando elementos para uma pedagogia da justiça. Cada um desses objetivos subsidiou 0 desenvolvimento de um capítulo específico para a presente dissertação, configurando, assim, um desenvolvimento lógico do texto que passo a explicar. ${ }^{12}$

Optamos por organizar a estrutura textual a partir do diálogo constante entre a teoria e a práxis. Desta forma, organizamos os capítulos a partir de temas geradores que possuem nas falas dos entrevistados e das entrevistadas o seu fio condutor. Não há, pois, uma estrutura hierárquica tradicional, na qual se apresenta inicialmente a fundamentação teórica, seguida da descrição de procedimentos metodológicos e, por fim, uma análise dos dados de forma segregada. Desde a primeira formulação conceitual, as experiências compartilhadas pelos integrantes da pesquisa fundamentam o argumento. Portanto, as principais informações obtidas nas distintas etapas da pesquisa serão apresentadas e analisadas ao longo do texto, enquanto categorias teóricas e políticas de análise do direito e da democratização da justiça.

É importante destacarmos que para o desenvolvimento da pesquisa e redação do texto de dissertação, assumimos o desafio de estudarmos um projeto que foi estruturante para nossa formação e concepção de mundo. Afinal, a cabeça pensa onde os pés pisam, e é a partir dessa realidade que buscamos os problemas e possibilidades de resposta para eles. É relevante pontuarmos que durante o desenvolvimento desta dissertação, a pesquisadora já não integrava o projeto. Esse fator foi, simultaneamente, relevante, uma vez que estando em um novo lugar, ampliam-se as possibilidades de enxergar novas perspectivas, mas também desafiador, na medida da existência de enorme envolvimento, inclusive afetivo, com o projeto.

\footnotetext{
12 Para além da necessária intersecção entre teoria e práxis no processo de elaboração da pesquisa - na qual a perspectiva crítica de direito e direitos humanos embasou desde a escolha do método até a coleta de dados - optamos também por uma apresentação que siga os mesmos parâmetros.
} 
Partindo da hipótese do EP atuar na democratização da justiça e da possibilidade em identificarmos, em sua práxis extensionista, elementos de uma pedagogia da justiça, desenvolvemos a pesquisa no marco político, pedagógico e teórico de ODANR. A Nova Escola Jurídica brasileira (NAIR), gênese de ODANR, representa um pensamento inovador no campo do direito e dos direitos humanos, e dialoga, de forma multidisciplinar, com os diferentes saberes e as diversas formas do conhecimento humano.

Referida multidisciplinaridade encontra no campo temático dos direitos humanos um espaço dialógico que permite a conversação entre a educação, o direito e a sociologia, e que será tratada, na pesquisa em desenvolvimento, a partir de referenciais múltiplos, com destaque para a compreensão pedagógica emancipatória em Paulo Freire (2012 e 2014), a teoria crítica do direito como liberdade em José Geraldo de Sousa Junior (2008) e a sociologia da justiça em Boaventura de Sousa Santos (2000; 2011; e 2014). Essas referências iniciais não exaurem as possibilidades teóricas da pesquisa, contudo, sintetizam, de forma emblemática, os caminhos analíticos percorridos para a compreensão do alargamento do conceito de democratização da justiça que será trabalhado.

Justificamos a inserção da pesquisa no bojo da produção científica de ODANR pelos múltiplos "deslocamentos" que fomenta: na consideração de novos sujeitos coletivos de direitos e novos atores nos processos para a democratização da justiça, aqui consubstanciados no reconhecimento de demandas coletivas de movimentos sociais e grupos oprimidos no contexto de atuação do Escritório Popular do Motyrum; e na consideração da prática extensionista em direito e em direitos humanos como instrumento contra-hegemônico para a produção e o reconhecimento de saberes. Assumimos, assim, o desafio de produzirmos um conhecimento não diletante, engajado com a transformação social, o fortalecimento da democracia e o exercício dos direitos humanos.

Seguindo a teoria crítica que é aprofundada pelo ODANR, adotamos como referência estudos que foram realizados por Roberto Lyra Filho, José Geraldo de Sousa (2008) Júnior e Roberto Aguiar. Estes autores se dedicaram, de forma pioneira, a explorar e expandir as dimensões do direito e do ensino jurídico a partir de experiências e concepções emancipatórias de cidadania, de justiça e para os direitos humanos. No que se refere aos direitos humanos, assumirá lugar de destaque na pesquisa a teoria crítica de Direitos Humanos tal como estruturada por Joaquín Herrera Flores (2009a e 2009b), pois constitui um autor que rompe com a 
concepção hegemônica de direitos humanos a partir da consideração de suas complexidades jurídica, científica, filosófica, política, econômica, cultural e empírica.

Por tratar-se de uma pesquisa com base empírica, que parte da práxis de um Escritório Popular e programa de extensão que desenvolvem suas atividades a partir de uma concepção de educação popular e assessoria jurídica que dialogam com aspectos fundantes da categoria "assessoria jurídica popular", realizamos uma revisão teórica sobre o tema, destacandos dissertações e teses produzidos entre 2004 e 2015 sobre o tema (GORSDORF, 2004; LUZ, 2005; MAIA, 2007; ALMEIDA, 2015; RIBAS, 2009).

Referenciamos a pesquisa no "movimento contemporâneo de juristas que busca compreender a produção do direito, não por meio de modelos abstratos, mas através de conflitos políticos vivenciados no ativismo dos movimentos sociais e na vida concreta dos 'sem-direitos'", tal como sintetiza Alexandre Mendes (2011, p. 79), ao contextualizar o pensamento intercultural de Joaquín Herrera Flores (2009).

Buscamos pensar novas "possibilidades teóricas" a partir de novas "condições sociais" (SOUSA JUNIOR, 2002, p.14), sob o influxo, em especial, da práxis dos movimentos sociais, compreendidos como sujeitos coletivos de direito que avançam na construção do direito como "legítima organização social da liberdade" (LYRA FILHO, 2003, p.86), isto é, mostram-se capazes de:

[...] instituir novos modos de vida e de juridicidade, não apenas do ponto de vista semântico (como fonte de argumentos que ajudam a criar novas interpretações para velhas categorias), mas também do ponto de vista pragmático (como fonte de práticas que inspiram novas formas de operabilidade do fenômeno jurídico (SOUSA JUNIOR et al, 2009, p. 14).

Nessa perspectiva, é necessário, mais do que apontar as ausências e insuficiências do paradigma positivista, estatalista e legalista dominante, passar à cartografia e pesquisa sociológica das experiências emergentes de produção insurgente do direito (SANTOS, 2000; SANTOS, 2003). Portanto, a observação das experiências de assessoria jurídica e advocacia popular procura responder justamente a esse apelo de Boaventura Santos contra o desperdício das experiências emergentes de ampliação democrática da justiça (GEDIEL; GORSDORF, ESCRIVÃO FILHO et al., 2011).

Por fim, partimos de uma compreensão teórica não apenas sobre direitos humanos, justiça, direito, movimentos sociais e assessoria jurídica popular, mas também sobre universidade, educação e extensão popular.

Diante da proposta de investigação, o percurso metodológico utilizado partiu de um levantamento bibliográfico acerca das questões que perpassam o estudo, como 
extensão universitária, educação em direitos humanos, acesso e democratização da justiça e teorias críticas de direito e direitos humanos, seguido da pesquisa empírica, a partir da qual foi possível conhecer a práxis do Motyrum.

Utilizamos uma triangulação qualitativa das informações (DENZIN \& LINCOLN, 2006), em que distintos procedimentos são adotados a fim de qualificar e dar maior densidade à análise dos dados coletados.

Para desenvolvermos a hipótese de investigação levantada (que é a hipótese de existência de elementos de uma pedagogia da justiça na práxis extensionista do Escritório Popular), elaboramos um projeto de pesquisa do tipo "qualitativo". Segundo a clássica definição de John Creswell, um projeto de pesquisa do tipo qualitativo constituise como um "[...] meio para explorar e para entender o significado que os indivíduos ou os grupos atribuem a um problema social ou humano." (CRESWELL, 2010, p.26). É, portanto, a tipologia adequada para resolver o problema de investigação estabelecido.

Como estratégia de investigação, desenvolvemos a pesquisa no formato de estudo de caso. Ainda segundo Cresweel, os:

[...] estudos de caso são uma estratégia de investigação em que o pesquisador explora profundamente um programa, um evento, uma atividade, um processo ou um ou mais indivíduos. Os casos são relacionados pelo tempo e pela atividade, e os pesquisadores coletam informações detalhadas usando vários procedimentos de coleta de dados durante um período de tempo prolongado. (CRESWELL, 2010, p.38).

O caso que escolhemos para analisar o fenômeno da democratização da justiça foi a práxis do Escritório Popular (EP) do programa de extensão Motyrum, compreendida como espaço universitário para uma pedagogia da justiça.

Em relação aos procedimentos que utilizamos para a coleta de dados da pesquisa empírica, recorremos às técnicas de pesquisa tradicionalmente empregadas nas abordagens qualitativas em ciências sociais, com destaque para: (i) entrevistas individuais semiestruturadas (Anexo B) desenvolvidas a partir de um roteiro temático préestabelecido, realizadas com o/a extensionista e advogado/as colaboradores/as do Escritório Popular; (ii) através de grupo focal com extensionistas e advogados/as atuantes no momento da visita em campo.

A etapa de análise documental se deu a partir dos registros de atuação do EP. Nesse sentido, foram analisados projetos e relatórios referentes ao EP e ao Motyrum, que foram produzidos no âmbito do Programa de Extensão Universitária 
(PROEXT) do Ministério da Educação (MEC), atas de reuniões internas do projeto e, ainda, registros referentes às suas atuações externas à instituição da UFRN, notícias referentes à atuação do Escritório Popular no contexto rio grandense do norte em que está inserido e considerando o recorte temporal que tem como termo inicial a sua formulação, em 2010, e como termo final o ano de 2014, documentos produzidos pelo/as extensionista do projeto e documentos de peças judiciais e outras atuações jurídicas desenvolvidas no âmbito do projeto. Em complementação, realizamos uma revisão bibliográfica da produção teórica, pedagógica e de participação cidadã desenvolvida a partir da experiência do EP.

Realizamos oito entrevistas com extensionistas participantes do EP, conduzimos um grupo focal, analisamos documentos sobre o projeto de extensão e revisamos a bibliografia especializada sobre o tema, tudo para coletarmos dados e informações confiáveis e atuais sobre o fenômeno investigado e, principalmente, identificarmos categorias de análise condizentes com o estado da arte do tema. Nota-se, portanto, que combinamos diferentes técnicas de pesquisa para a realização do estudo proposto. A riqueza e a complexidade das atividades realizadas merecem um relato específico, motivo pelo qual passo a tecer algumas considerações sobre a metodologia empregada.

A principal característica da pesquisa foi constituir-se numa observação não participante sobre o fenômeno analisado. Embora, como foi dito anteriormente, tenhamos participado do projeto de extensão objeto da pesquisa ao longo de nossa graduação em direito, é fato que a investigação realizada em nível de mestrado ocorreu em um momento posterior, em que não estávamos mais envolvidos com o objetosujeito de análise. Decorrente desse envolvimento foi necessário estabelecermos estratégias para a coleta de informações que pudessem diminuir as nossas preconcepções e percepções sobre os eventos e caso analisados. A combinação de técnicas de pesquisa emergiu, portanto, como possibilidade para "mitigar" as compreensões prévias, como um elemento de desvelamento da realidade que, sem anular o histórico e local de fala da pesquisadora, permitiu a captação de novas percepções e compreensões sobre o fenômeno investigado.

Elaboramos para as entrevistas um roteiro semiestruturado que foi utilizado como guia (Anexo B). Organizamos tematicamente o roteiro em duas partes ou tópicos gerais: dedicamos a primeira à identificação e estruturação do projeto e a segunda às concepções do e no EP. Sua elaboração foi guiada por questões geradas a partir da 
hipótese e dos objetivos de pesquisa e contou com a realização de um pré-teste com duas pessoas extensionistas do EP.

O pré-teste do roteiro que elaboramos para as entrevistas semiestruturadas consistiu em um importante momento da pesquisa, no qual pudemos redefinir os temas e a abordagem que seria realizada $e$, inclusive, pudemos perceber a necessidade de realizar a gravação das falas acompanhada de anotações pela pesquisadora (ou seja: durante as entrevistas gravamos, em áudio, todas as falas e, ainda, utilizamos um caderno de campo para irmos anotando as principais informações e respostas das entrevistadas). Também pudemos perceber, durante o pré-teste, a necessidade de reformularmos algumas perguntas/temas para não induzir respostas a partir da própria experiência vivenciada pela entrevistadora no projeto durante a sua participação enquanto extensionista.

Realizamos as entrevistas presencialmente com oito integrantes do projeto que atuaram no Escritório Popular como extensionistas da graduação e/ou como advogados ou advogadas. O critério de inclusão dos participantes foi o tempo de pertencimento ao projeto, tendo em vista privilegiar a escuta dos sujeitos que têm uma visão histórica de sua totalidade ou da maior parte de seu tempo de existência. Dos oito, quatro são integrantes do mesmo desde a sua fundação; todas e todos passaram ou estão há pelo menos três anos no projeto.

A escolha por não entrevistarmos os e as docentes que estiveram, em diferentes momentos, à frente da coordenação do projeto, deveu-se pela ausência de orientação efetiva e de coordenação real ao longo dos anos de atividade extensionista. Como é característico da extensão universitária, o protagonismo estudantil e dos sujeitos com quem se atua é uma marca do Motyrum e do Escritório Popular. Sem pretender desqualificar a atuação de diversos docentes que passaram ou estão no Programa Motyrum, esta pesquisa priorizou dar voz e visibilidade para os sujeitos implicados organicamente na práxis da extensão: os e as extensionistas.

As entrevistas duraram de 90 (noventa) a 130 (cento e trinta) minutos cada e o local para as suas realizações foi estabelecido pelas próprias pessoas entrevistadas. Com isso, garantimos a participação das oito pessoas convidadas para a pesquisa. As entrevistas foram majoritariamente realizadas nas residências das próprias pessoas, sendo que somente uma pessoa foi entrevistada em seu local de trabalho.

A segunda técnica de pesquisa qualitativa que empregamos foi a condução de um grupo focal integrado por sete sujeitos do projeto. Realizamos o grupo em momento 
posterior às entrevistas e contamos com um roteiro que elaboramos para a atividade. Preparamo-lo utilizando frases proferidas pelos sujeitos durante as entrevistas individuais. Com duração aproximada de 90 (noventa) minutos, iniciamos o grupo com a leitura de frases pela pesquisadora-condutora e a manifestação espontânea dos participantes ao sentirem-se provocados pelo conteúdo do que foi lido.

Para o grupo focal, construímos um guia de tópicos (BARBOUR, 2009) a partir de falas dos próprios participantes nas entrevistas individuais realizadas (Anexo C), usadas como elementos disparadores dos debates do grupo, a fim de aprofundar compreensões, análises e formulações. Tal construção baseou-se no método freireano, de educação popular crítica, na medida em que partimos de um levantamento preliminar de informações sobre o projeto a ser investigado (relatórios, projetos, trabalhados acadêmicos, registros de grupo de e-mails), em seguida escutamos os sujeitos integrantes dessa experiência (nas entrevistas semiestruturadas e conversas informais) e daí destacamos falas significativas para a elaboração de questões geradoras que utilizamos como roteiro do grupo focal, a fim de aprofundarmos o diálogo, coletivamente, sobre o que viriam a ser conceitoschave e categorias nesta pesquisa. Aqui nos inspiramos na metodologia proposta pelo professor doutor Antônio Fernando Gouvêa da Silva (2005), que sistematiza os momentos organizativos para a busca do tema gerador a partir da práxis, tendo em vista a perspectiva freireana de uma concepção educacional libertadora ${ }^{13}$.

A opção por utilizarmos as entrevistas individuais e o grupo focal deve-se à possibilidade de aprofundarmos, a partir da circulação da palavra que somente o grupo proporciona, a visão e atuação do grupo e do projeto como um todo, para juntamente com as percepções individuais de cada um e de cada uma, enriquecer a investigação. Além disso, realizarmos exclusivamente grupos focais poderia limitar a coleta de informações, tendo em vista que o tempo e o número de pessoas do grupo poderiam impossibilitar que todos os integrantes dessem sua contribuição de forma mais ampla.

Após realizarmos as entrevistas e o grupo focal, degravamos todas as falas utilizando sistema não especializado de reprodução de áudio (Windows Media Player). Esse trabalho consumiu cerca de três meses de trabalho e contou com a ajuda de uma equipe auxiliar para a degravação. Ainda assim, o processo de ouvir os áudios, conferir

\footnotetext{
${ }^{13}$ Recomendamos seu livro "A busca do tema gerador na práxis da educação popular: Metodologia e
} sistematização de experiências coletivas populares". (SILVA, 2005), 
as transcrições e padronizar a apresentação dos textos das falas foi exclusivamente realizado pela pesquisadora.

A quantidade de páginas de texto que transcrevemos das entrevistas e a riqueza das informações que coletamos reforçaram a necessidade de recorrermos a um software específico para auxiliar a análise qualitativa das falas. Dentre as opções disponíveis, decidimos pela utilização de um software de apoio à organização de dados qualitativos denominado QDA-Miner (Qualitative Data Analysis Software).

A utilização de softwares para análises qualitativas é assunto polêmico no bojo das ciências sociais. As maiores críticas apontam para a descontextualização de falas e a redução do espaço para a reflexão analítica como sendo vícios decorrentes da referida utilização. Contudo, é preciso destacar que o QDA-Miner não usurpa o papel reflexivo do pesquisador e tão pouco randomiza termos e expressões, criando categorias aleatórias. Pelo contrário: sem contar com qualquer tipo de seletor automático, o QDA-Miner apenas apresenta uma interface de edição de textos que facilita o trabalho de categorização que é única e exclusivamente realizada pelo pesquisador ${ }^{14}$. Assim, apoiada na retromecionada ferramenta para sistematização de categorias, todas as entrevistas transcritas foram analisadas e as falas foram interpretadas à luz das perguntas que as orientaram.

Além dos procedimentos metodológicos, consideramos ser relevante 0 registro de algumas das percepções que experimentamos na pesquisa de campo, e que consideramos uma contribuição valorosa à pesquisa empírica em direito e em direitos humanos.

A ida a campo foi precedida da leitura de textos científicos sobre técnicas de pesquisa qualitativa. Não obstante, notamos tanto a ausência de pesquisas empíricas em direito e em direitos humanos, como a de pesquisas empíricas que tivessem a preocupação e o cuidado de compartilhar como foi a realização do campo. As dificuldades, os desafios, as percepções e as escolhas que deram certo ou errado no bojo da execução de outras pesquisas empíricas constituem uma modalidade de informações não disponíveis ou registradas em fontes abertas de registros acadêmicos para outros pesquisadores. Nota-se, portanto, que importantes informações sobre os

\footnotetext{
${ }^{14}$ Sobre o QDA-Miner, conferir: Hernandez, A. R. C. (2008). Análise qualitativa usando o programa QDA Miner: um exemplo aplicado de pesquisa: análise documental de textos de protesto. In Scarparo, H. (Org.), Psicologia e Pesquisa: perspectivas metodológicas. Porto Alegre: Sulina. p. 151-168.
} 
caminhos das pesquisas empíricas realizadas, especialmente, no âmbito do direito não são compartilhadas pela comunidade científica e acadêmica ${ }^{15}$.

A segunda percepção que obtivemos em campo guarda relação com a escolha dos sujeitos que entrevistamos. Seguindo as orientações da professora doutora Nair Heloisa Bicalho de Sousa e que foram transmitidas durante a banca de qualificação do projeto de mestrado, buscamos identificar e priorizar para a etapa de entrevistas os sujeitos que estavam há mais tempo no projeto, partindo da premissa que teriam uma visão de sua totalidade, pois teriam condições de fazer uma análise do projeto como um todo, mais ampla que de períodos ou episódios pontuais. Só que para decidir quem seria os sujeitos a ser entrevistados, precisávamos saber quem eram os sujeitos que já haviam passado pelo projeto, ou seja, qual era o universo de extensionistas do EP. A primeira surpresa que tivemos foi percebermos a inexistência dessa informação, que não estava registrada em nenhum lugar. O levantamento das pessoas que haviam integrado o EP passou a constituir, portanto, a primeira atividade realizada em campo. Primeiro, realizamos conversas informais e contatos iniciais para procurarmos documentos e registros sobre os extensionistas e para conhecer o universo total das pessoas que haviam passado pelo projeto. Somente a partir daí é que pudemos definir o universo de sujeitos da pesquisa e, consequentemente, as entrevistas.

Da percepção de que o próprio universo daquilo que será pesquisado pode ser desconhecido pelos sujeitos que vivenciam determinados fenômenos, decorre a terceira percepção de campo: a de que é praticamente impossível estabelecer, com rigor e a priori, o tempo da pesquisa de campo. Os imprevistos, as novidades inesperadas, a diversidade dos achados de campo e o tempo necessário para haver a devida decantação e análise do fenômeno observado integram um conjunto de fatores que dificulta o real dimensionamento do tempo necessário para a realização da pesquisa empírica. Sucessivos eventos acabam impactando o cronograma de um projeto de pesquisa empírica de abordagem qualitativa, sendo alguns deles positivos (exemplos: o descobrimento de novos documentos e a disponibilidade de sujeitos em realizar entrevistas mais longas) e outros negativos (exemplos: a constatação de que o processo de degravação demanda mais horas de trabalho do que o inicialmente cogitado).

\footnotetext{
${ }^{15}$ Senti o impacto concreto da falta de formação para fazer pesquisa empírica no decorrer de todo o campo. Conforme fui desenvolvendo a pesquisa, fui percebendo como a decisão de realizar uma pesquisa de campo envolve etapas preparatórias para o antes, o durante e o depois. Essa falta de preparação me provocou em relação à formação do curso de direito: para que somos preparadas? $\mathrm{O}$ alheamento à realidade social parece se revelar também nessa dimensão de compreensão de uma pesquisa que não precisa ir a campo.
} 
A questão do tempo em pesquisas qualitativas merece atenção, pois existe um momento de "digestão" das informações que é necessário conferir ao pesquisador para que possa interpretar, em toda a sua complexidade, o fenômeno observado. No caso específico da pesquisa realizada, percebemos que seria necessário um tempo maior para "digerirmos" e "decantarmos" tantas informações obtidas a partir do processo de entrevistas. E considerando que o objetivo do grupo focal era aprofundar questões já abordadas nas entrevistas, teria sido muito mais adequado termos um tempo maior entre os dois processos, para revisitarmos as entrevistas, analisamo-las melhor e escolhermos os temas que priorizaríamos no grupo.

No caso específico das pesquisas realizadas com e a partir de projetos de extensão essa percepção é desafiadora, pois as ações extensionistas são marcadas por uma tradição oral muito forte que é intrínseca à sua própria natureza de comunicação, tal como reivindicava Paulo Freire. A quarta percepção de campo consiste, portanto, na identificação de que o "quefazer" dos projetos de extensão é dialógico e necessariamente coletivo, tornando não só desafiador como, também, difícil o trabalho de sistematização e registro de suas atividades.

Essa quarta percepção adquire contornos específicos quando problematizamos o envolvimento docente na extensão universitária. A ausência de docentes desempenhando efetivamente um papel de coordenação dos projetos e programas de extensão universitária reflete-se também nessa dimensão da falta de sistematização de informações, de relatórios periódicos e de produção de pesquisa sistematizada a partir das atividades extensionistas. É comum encontrarmos professores que assinam os projetos, mas que não estão presentes em seu cotidiano de atuação. Notamos, em campo, indícios do autoritarismo e da ausência de docentes no cotidiano da extensão universitária.

A quinta percepção que selecionamos para compartilhar refere-se à recepção dos sujeitos à pesquisa e à etapa de campo, notadamente nos momentos de realização das entrevistas e do grupo focal. Fomos surpreendidos pela acolhida e pelo entusiasmo com fomos recebidos. Houve falas no sentido de que a atividade extensionista demanda bastante tempo e a natureza de boa parte das demandas do EP é urgente, portanto, há pouco tempo/espaço para momentos de reflexão e formulações. Assim, a acolhida foi também em relação a ser uma oportunidade valiosa de contribuição com/para o projeto, na medida em que a pesquisa propõe ouvir os sujeitos e sistematizar e formular compreensões, concepções e a própria experiência. 
Outra percepção surpreendente, a sexta em relação ao trabalho de campo e à pesquisa empírica, foi relacionada ao desafio e à vantagem do lugar de fala. Antes de iniciarmos o processo de entrevistas, realizamos um pré-teste do roteiro de entrevistas com dois integrantes do projeto que ouviríamos no campo. Tratou-se de uma conversa informal conjunta em questionamentos que fizemos aos entrevistados a fim de perceber primeiras impressões e caminhos que pudessem dar diretrizes para o instrumental das entrevistas. Nesse momento do pré-teste ficou muito evidente como o envolvimento pessoal, acadêmico, profissional e até político da pesquisadora poderia ser também um desafio para o momento de escuta dos sujeitos da pesquisa. Só depois desse primeiro momento "piloto" é que percebemos as efetivas dificuldades para fazermos uma escuta sensível e cuidadosa dos sujeitos, principalmente pelo fato da pesquisadora, enquanto egressa do projeto extensionista, querer, em vários momentos, dar vazão às suas próprias versões de fatos e respostas. Esse momento foi fundamental para refletirmos sobre como deveria ser a postura de pesquisadora nas entrevistas ao assumir um papel observante não participante ${ }^{16}$.

A partir da escuta dos sujeitos foi possível identificamos demandas colocadas para esta pesquisa e que foram, à medida do possível, incorporadas. Isso, para nós, segue a perspectiva freireana em que os temas geradores vêm depois da escuta sensível dos sujeitos com quem se dialoga. Incorporamos demandas como a construção de uma linha do tempo do projeto, o esforço de sistematizarmos a experiência, a reflexão sobre o projeto a partir de sua práxis, tendo em vista a dificuldade de ter momentos de reflexão coletiva em virtude da agenda de conflitos com que o EP atua, e a localização do EP como um núcleo de assessoria jurídica universitária popular com referência na RENAP, disputando uma concepção de possibilidade de advocacia popular na extensão.

\footnotetext{
${ }^{16}$ Foi um desafio ao longo de todo o processo de campo, o de encontrar um equilíbrio na postura em relação aos sujeitos. Não fiquei calada o tempo todo, porque não achava que esse era meu papel, mas tampouco podia deixar de exercitar a escuta sensível a que se referia Paulo Freire e ouvir efetivamente os sujeitos. Foi depois do piloto que compreendi que estava agora num novo lugar de fala em relação ao projeto, ou seja, já não mais como integrante/extensionista, mas como pesquisadora. Isso não quer dizer, de forma nenhuma, assumir uma postura pretensamente neutra ou imparcial em relação ao objeto da pesquisa ou à própria produção de conhecimento, concepção com que guardo divergência. Já dizia Paulo Freire que um elemento essencial no processo educativo é a compreensão da intencionalidade política que permeia a leitura de mundo. $O$ equilíbrio buscado foi no sentido de estabelecer no campo um diálogo, mas priorizando o processo de escuta dos sujeitos entrevistados em relação à minha própria fala.
} 
Foi muito interessante ouvirmos pedidos dos entrevistados para que enviássemos o roteiro das entrevistas posteriormente, alegando que as perguntas provocadoras foram avaliadas como ricas e que poderiam ser utilizadas para momentos posteriores de formação do projeto. Houve uma avaliação por parte de alguns sujeitos, no decorrer da entrevista, de que ao mesmo tempo em que a resposta para determinadas questões lhe parecia óbvia, havia também a percepção de que aquela reflexão nunca havia sido feita coletivamente no projeto, ou que não havia formulação conjunta sobre aquilo.

Outro ponto que se revelou como surpreendente no processo de campo foi a percepção sobre a dimensão opressora do saber acadêmico. Estávamos ali para ouvirmos os sujeitos sobre seus cotidianos, sobre seu "quefazer" extensionista, e tenho uma relação de companheirismo com os sujeitos, de quem já partilhou daquela experiência do mesmo lugar de fala que eles e, apesar disso, foi muito comum, em todas as entrevistas, ouvir nas respostas uma ponderação e receio de que não sabia se aquela resposta estava "certa". A percepção foi a do lugar de autoridade automaticamente ocupado por alguém que fala (ou até mesmo que ouve, como no caso) a partir da universidade e que nos remete à uma ideia de hierarquização de saberes, na medida em que parecia que eu, que estava no lugar de pesquisadora naquele momento, poderia saber e dizer qual a resposta "certa", mais do que eles, sujeitos que cotidianamente compreendem aquelas questões a partir de sua práxis. Essa concepção vai de encontro à nossa perspectiva de educação dialógica, horizontal e sem hierarquização de saberes, conforme a proposta de Paulo Freire. Ali ficou evidente a construção histórica da universidade e do saber acadêmico como hierarquicamente superiores. Foi um elemento muito sutil, na medida em que as pessoas estavam dialogando muito à vontade, mas esteve presente.

Foi muito rico percebermos e observarmos os olhares, as expressões, os silêncios, que falavam tanto. Imaginamos que se o roteiro que utilizamos nas entrevistas fosse enviado, previamente, por e-mail, teríamos perdido grande parte da riqueza desse momento do campo. Começamos a perceber, por exemplo, que foram as mesmas perguntas que despertaram os maiores silêncios, divagações e incertezas das pessoas entrevistas. As hesitações e aparentes incômodos foram notados em momentos semelhantes, assim como também percebemos momentos em que essas mesmas pessoas pareciam sentir-se mais à vontade, enfim, alguns 
padrões de dúvidas e questionamentos eram mais perceptíveis pela linguagem corporal e fisionômica que pelas palavras em si.

Conforme poetiza Guimarães Rosa em seu "Grande Sertão - Veredas": "Surgiu o silêncio deles todos. Aquele silêncio que pior que uma alarida."17

17 Registramos aqui que o verso de Rosa impresso na parede de uma das salas de estudo da Biblioteca Central de Estudantes (BCE) da UnB e lá lido cotidianamente em determinado período de análise dos dados e escrita desta dissertação foi inspirador para as reflexões sobre os silêncios e demais manifestações semelhantes durante a pesquisa de campo. Por mais poesias em nossos caminhos é que fazemos esse registro. 


\section{CAPÍTULO 1 DAS LIÇÕES DE CIDADANIA AO MOTYRUM: o caminho se faz caminhando.}

Na verdade, o meu reencontro com a Pedagogia do oprimido não tem o tom
de quem fala do que já foi, mas do que está sendo.

Paulo Freire, 1992.

O que dá grandeza às universidades não é o que se faz dentro delas. É o que se faz com o que elas produzem.

Florestan Fernandes, 1959.

O Escritório Popular (EP), objeto da pesquisa acadêmica que sustenta a presente dissertação de mestrado, é um projeto de extensão universitária ${ }^{18}$ desenvolvido na Universidade Federal do Rio Grande do Norte (UFRN).

Essa experiência de extensão em direito e em direitos humanos tem revelado elementos que parecem sinalizar para a construção de processos democratizantes de justiça e que perpassam desde a inquietação diante do que "é" e do que "deve ser" extensão universitária, educação e ensino jurídico ${ }^{19}$ e o diálogo com os "sem-direitos" (DUSSEL, 2001), até a ruptura com o "senso comum teórico do jurista" (WARAT,1994) e a formação de advogados e advogadas populares ${ }^{20}$.

18 Optamos pela utilização da expressão "extensão universitária" por considerarmo-la uma categoria de análise. Conforme apresentaremos ao longo desta dissertação, existem diferentes acepções do termo, como, por exemplo, a extensão rural associada a ações voltadas para o incremento e desenvolvimento técnico agrícola. Contudo, dedicamos a pesquisa à análise de uma modalidade específica de extensão que é desenvolvida no âmbito universitário, considerando sua configuração enquanto instituição de ensino superior: a universitária.

19 Destacamos que educação e ensino jurídico não são sinônimos, tendo em vista que o ensino jurídico é apenas uma das dimensões do processo educativo, ainda que frequentemente este seja confundido com aquele. Nesse sentido, as reflexões do professor José Geraldo de Sousa Junior: "estudar Direito implica elaborar uma nova cultura para as Faculdades e cursos jurídicos e, um dos eixos fundamentais dessa reformulação cultural tem sido, à luz das diretrizes em curso, constituir-se a educação jurídica uma articulação epistemológica de teoria e prática para suportar um sistema permanente de ampliação do acesso à justiça (Sousa Júnior e Costa, 1998), com a abertura a temas e problemas críticos da atualidade, dando-se conta ao mesmo tempo, das possibilidades de aperfeiçoamento de novos institutos jurídicos para indicar novas alternativas para sua utilização (Sousa Júnior, 2006:31)" (SOUSA JUNIOR, 2011, p.65).

20 Adotamos como conceito provisório de advocacia popular a seguinte formulação proposta por Ana Claudia Diogo Tavares a partir de pesquisa empírica realizada sobre concepções e atuação de advogados e advogadas populares: "Em relação ao advogado popular, as narrativas expressam um certo grau de uniformidade, destacando-se: o compromisso político-ideológico com as lutas sociais ou com as demandas coletivas, o diálogo com os "assessorados", o posicionamento ao lado e junto aos movimentos e ser um instrumento para a conquista de direitos. Nesse sentido, dominar a técnica e, ao mesmo tempo, contribuir com a reflexão sobre o novo direito visando romper com os valores positivistas. " (TAVARES, 2007, p.130). No terceiro capítulo desenvolvemos esse conceito, problematizando-o. 
O EP foi criado em $2010^{21}$ como parte de um programa de extensão denominado "Programa de Educação Popular em Direitos Humanos Lições de Cidadania" (também conhecido como "Lições de Cidadania" ou "Lições"22) que, por sua vez, foi fundado em 2005 e reestruturado em 2013, ano em que passou a chamar-se "Programa Motyrum de Educação Popular em Direitos Humanos" (Motyrum). ${ }^{23}$

Assim localizado, a história e o desenvolvimento do EP perpassam tanto 0 "Lições" como o "Motyrum". Portanto, entender o contexto de criação, a estrutura de organização, as escolhas metodológicas e de intervenção na realidade do "Lições", do Motyrum e do EP constitui-se etapa relevante para provocar reflexões e contribuições para e a partir de um marco de educação em direitos humanos, cujas diretrizes de interdisciplinaridade, diálogo de saberes, horizontalidade, intencionalidade política e outras escolhas epistemológicas permeiam as trajetórias do projeto.

Neste primeiro capítulo apresentaremos o Lições de Cidadania e dedicaremos atenção à estruturação do Motyrum, tendo em vista que para descrever o desenho institucional do Escritório Popular, um dos objetivos desta dissertação, é necessário conhecer o Programa de extensão onde ele está localizado.

\subsection{Conhecer, despertar, dialogar, avaliar e celebrar: o Programa Motyrum de Educação Popular em Direitos Humanos.}

O Escritório Popular é um dos projetos que compõem o programa Motyrum de educação popular em direitos humanos, programa de extensão universitária em direito e em direitos humanos da UFRN. Para compreender sua localização é importante conceituar para diferenciar "projeto de extensão" e "programa de extensão".

As ações de extensão universitária da UFRN são regulamentadas pela Resolução no 53, de 15 de abril de 2008 do Conselho de Ensino, Pesquisa e Extensão

\footnotetext{
${ }^{21}$ O primeiro registro formalizando o EP data de 2011, porém, em nossa pesquisa documental e de campo, identificamos que o surgimento do projeto, com os debates sobre seu nome, concepção e início da atuação, ocorreu em 2010.

22 Para facilitar a leitura do texto, tornando-a mais fluída, utilizaremos as seguintes abreviações: "Lições" e "Lições de Cidadania" designarão, indistintamente, o Programa de Educação Popular em Direitos Humanos em sua formulação inicial (período de 2005 a 2013); "Motyrum" será utilizada para designar o mesmo programa, porém, em um período distinto e posterior, em que passou por uma reformulação (2013); já a abreviação "Escritório Popular" designará o projeto de extensão que foi objeto da pesquisa acadêmica ensejadora da presente dissertação de mestrado, e que é desenvolvido no bojo do Motyrum.

23 No processo de contextualização e historicização do EP, apresentaremos um panorama do desenvolvimento do programa, destacando alguns elementos que marcaram a alteração substantiva do programa do momento inicial do "Lições" para a sua configuração mais recente em "Motyrum".
} 
(CONSEPE). Segundo o artigo 2 dessa resolução, são consideradas como modalidades de "ações de extensão" os programas, os projetos, os cursos, os eventos, os produtos e a prestação de serviços.

De acordo com o artigo $3^{\circ}$ da resolução, um programa de extensão é definido como um "conjunto de ações" que estão "[...] coerentemente articuladas ao ensino, à pesquisa e/ou produção cultural, integradas às políticas institucionais da Universidade e direcionadas às questões relevantes da sociedade, com caráter estruturante, regular e continuado." A caracterização de um programa de extensão depende da identificação de pelo menos três "[...] ações de caráter continuado e que envolvam algumas das modalidades [de ações extensionistas] definidas no art. 20" (art. $\left.3^{\circ}\right)$. Já os projetos de extensão universitária são definidos como sendo uma modalidade de ação extensionista voltada para a "[...] atuação na realidade social, de natureza acadêmica, com caráter educativo, social, artístico, cultural, científico ou tecnológico, e que cumpram os preceitos da indissociabilidade entre ensino, pesquisa e extensão, desenvolvidas de forma sistematizada" (art. $5^{\circ}$ ).

Assim, tanto o Lições como o Motyrum caracterizam-se como programas de extensão que são constituídos por pelo menos três projetos de extensão. Pertinente à pesquisa dissertada, o "Escritório Popular" consiste em um dos projetos desenvolvidos no âmbito do programa Motyrum.

O EP surgiu entre os anos de 2010 e 2011, a partir de demandas por assessoria jurídica das comunidades e movimentos sociais com as quais o então Lições de Cidadania atuava e do contato e aproximação com a Rede Nacional de Advogados e Advogadas Populares (RENAP).

Atualmente, o Motyrum se afirma como um programa de ensino, pesquisa e extensão universitária que desenvolve atividades de educação popular em direitos humanos ${ }^{24}$ e é vinculado ao Departamento de Direito Público do Centro de Ciências Sociais Aplicadas da UFRN. Conforme consta em seu registro na Pró-Reitoria de Extensão da Universidade (PROEX) ${ }^{25}$ :

\footnotetext{
${ }^{24}$ Apesar de se caracterizar como programa de extensão universitária desde 2009 (até então era projeto), verificamos algumas lacunas no processo de formalização do Motyrum junto à Pró-Reitoria de Extensão da UFRN, seja na falta de registros e/ou sistematizações em determinados períodos, seja na caracterização do registro não correspondendo à sua situação real. No registro do ano de 2015 do Motyrum junto à PróReitoria, por exemplo, a ação extensionista foi equivocadamente formalizada como "projeto", apesar de constar em seu nome a designação "programa".

25 Registros das ações de extensão da UFRN, inclusive do Motyrum, podem ser conferidas online. Disponível em: <www.sigaa.ufrn.br>. Acesso: 28 jan. 2016.
} 
O Programa é composto por seis grandes projetos, também denominados de núcleos de atuação, e são eles: Motyrum InfantoJuvenil, que se propõe a atuar em escolas estaduais do município de Natal/RN, em situação de vulnerabilidade social; Motyrum Rural, que atua em assentamentos rurais e ambientes de reforma agrária; Motyrum Urbano, que age em comunidades urbanas que enfrentam a violação dos Direitos Humanos; Motyrum Penitenciário, que desenvolve suas atividades em ambientes de privação de liberdade; Motyrum Indígena, que atua nas comunidades indígenas do Estado; e Motyrum Escritório Popular, que lida com as demandas jurídicas que surgem nas comunidades e locais que os demais núcleos atuam, além de uma assessoria jurídica a movimentos sociais.

A nucleação desses projetos de extensão no programa Motyrum dá-se a partir das realidades vividas pelos sujeitos com quem as e os extensionistas atuam: a urbana, a rural, a infanto-juvenil, a de privação de liberdade e as de comunidades indígenas. A exceção a essa lógica de nucleação é o EP, que pode agregar demandas das diversas realidades. O EP possui uma nota distintiva em relação aos demais núcleos do Motyrum que é o fato de ser o único que agrega casos envolvendo o sistema de justiça e questões judiciais. Para facilitar a visualização da configuração organizativa do programa e a localização do Escritório Popular dentro dela, apresentamos o organograma abaixo:

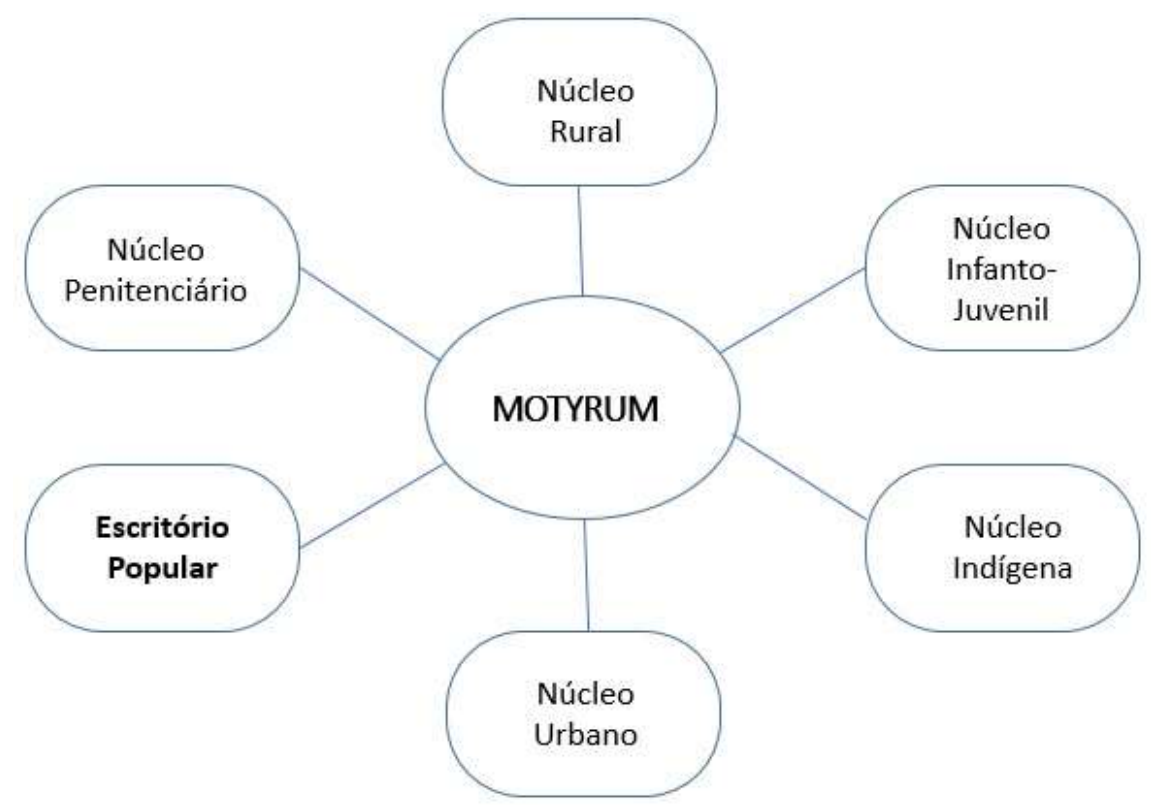

Figura 1: Núcleos (Projetos de extensão) do Programa Motyrum

Fonte: elaboração da autora, 2016.

O que caracteriza as nucleações e as ações do Motyrum é a dimensão de "povo", elemento que compõe a centralidade da qualificação "popular" que caracteriza tanto o escritório (EP) como a concepção de educação adotada pelo programa. A partir da pesquisa realizada, identificamos que o projeto trabalha com uma ideia de povo que se aproxima da concepção de Enrique Dussel: 
Assim, povo é o "bloco comunitário" dos oprimidos de uma nação. O povo é constituído pelas classes dominadas (classe operário-industrial, camponesa, etc.), mas além disso por grupos humanos que não são classe capitalista ou exercem práticas de classes esporadicamente (marginais, etnias, tribos, etc.). Todo este "bloco" - no sentido de Gramsci - é o povo como "sujeito" histórico da formação social, do país ou nação. (DUSSEL, 1986, p. 97).

Identificamos, também, que a concepção de Dussel dialoga diretamente com a de Fidel Castro, conforme seu discurso diante do Tribunal de Exceção de Santiago de Cuba, em 16 de outubro de 1953. Apesar da extensão do trecho, consideramos relevante transcrever integralmente as palavras de Castro, pois sua compreensão sobre quem é o "povo cubano" acaba sendo uma formulação mais ampla sobre quem é o "povo":

Quando falo de povo não me refiro aos setores acomodados e conservadores da nação, os quais acham bom qualquer regime de opressão, qualquer ditadura, qualquer despotismo, prostrando-se diante do senhor da época até quebrar a testa no chão. Quando falo de luta, entendo por povo a grande massa oprimida, à qual tudo prometem, enganam e atraiçoam; que aspira a uma pátria melhor, mais digna e mais justa; que é movida por anseios ancestrais de justiça por haver sofrido, geração após geração, a injustiça e a zombaria; que, em todos os sentidos, almeja grandes e sábias transformações e está disposta a dar a última gota de sangue para consegui-lo, quando acredita em alguma coisa ou em alguém, sobretudo quando acredita suficientemente em si mesma. [...] Ao enfrentar a luta, convocamos o povo, os seiscentos mil cubanos que estão sem trabalho, desejando ganhar o pão honradamente sem ter que emigrar de sua pátria em busca de sustento; os quinhentos mil operários do campo que vivem nos bohíos [cabanas feitas de madeira e ramos, varas ou palhas, sem nenhuma abertura além da porta. Era usada pelos aborígenes das Antilhas], que trabalham quatro meses no ano, passando fome o tempo restante, compartilhando a miséria com seus filhos que não têm uma polegada de terra para semear e cuja existência deveria inspirar compaixão, caso não existissem tantos corações de pedra; os quatrocentos mil operários industriais e braçais, cujos ingressos estão todos desfalcados, cujas conquistas Ihes estão sendo arrebatadas, cujas casas são cortiços infernais, cujos salários passam das mãos do patrão para as do garrotero [nome que serve para designar os usuários e os agiotas], cujo futuro é a redução do salário e dispensa do emprego, cuja vida é o trabalho eterno e cujo descanso é o túmulo; os cem mil pequenos agricultores, que vivem e morrem trabalhando na terra que não é sua, sempre contemplando-a, como Moisés contemplava a Terra Prometida, até morrer sem chegar a possuí-la; que têm de pagar, como os servos feudais, por sua parcela com uma parte de seus produtos, que não podem amar a terra, melhorá-la e embelezá-la, nem plantar um cedro ou uma laranjeira, porque ignoram o dia em que virá o oficial de justiça com a guarda rural para dizer-Ihes que devem sair; os trinta mil professores primários e demais professores, tão abnegados, sacrificados e necessários para que as futuras gerações tenham um melhor destino, e aos quais se trata e paga tão mal, os vinte mil, pequenos comerciantes esmagados pelas dívidas, arruinados pela crise e destruídos por uma praga de funcionários aventureiros e venais; os dez mil jovens profissionais: médicos, engenheiros, advogados, veterinários, pedagogos, dentistas, farmacêuticos, jornalistas, pintores, escultores etc., que ao sair das escolas com seus diplomas, desejoso de lutar e cheios de esperança, encontramse num beco sem saída, com todas as portas fechadas, surdas ao clamor e à súplica. Esse povo é que sofre todas as desditas e, portanto, é capaz de combater com toda coragem! (CASTRO, 1979, p.45) 
Assim, a perspectiva "popular" agregada ao Programa e adotada na caracterização de sua práxis educativa, diz respeito aos sujeitos com quem escolhe desenvolver sua atuação extensionista. É nesse sentido o manifesto que anuncia a escolha do nome Motyrum (Nota do Programa Motyrum sobre a mudança de nome Anexo A) e, ao fazê-lo, reafirma e demarca essa compreensão de povo:

\author{
"Não há paz, quebram até as flores." \\ "E de guerra em paz \\ De paz em guerra \\ Todo o povo dessa terra \\ Quando pode cantar \\ Canta de dor."
}

Por isso precisávamos de um nome, de uma identidade, de uma palavra popular, feminista, negra, indígena, da juventude, dos oprimidos, dos condenados da terra, condenados do mundo e da história, que indicasse nossa opção lúcida e consciente pelos explorados e exploradas, pela libertação das correntes opressoras. Assim, escolhemos um novo nome que simboliza o nosso comprometimento com a luta histórica dos povos que tiveram sua identidade roubada, assim como ainda ocorre hoje em todos os espaços em que atuamos. Favelas, Campos, Presídios, comunidades indígenas, etc. Escolhemos um nome que significa mais que a união de pessoas, mais que um simples mutirão. Talvez ainda mais que um "tamo junto". Escolhemos um nome que simboliza a resistência, a luta e a revolução.

Desse modo:

"Aos Povos do Terceiro Mundo

que vencem o fratricídio

À mulher

camponesa e proletária

que suporta o uxoricídio

À juventude

Do mundo inteiro que e rebela contra o filicídio

Aos Anciões

sepultados vivos nos asilos."

Somos, a partir de agora, Programa Motyrum de Educação Popular em Direitos Humanos.

Entretanto, o Motyrum nem sempre foi como é hoje. Como tem sido característico da própria concepção de extensão universitária no Brasil, que nas últimas décadas vem passando por alterações estruturantes, a mutabilidade também tem sido um dos elementos presentes na história do programa. Para compreendê-lo e a seus processos, é fundamental resgatarmos sua historicidade e suas transformações ao 
longo dessa década de existência, pois tal qual o caminho se faz caminhando (FREIRE; HORTON, 2009), como ensinou Paulo Freire, o programa é, sendo 26.

Olhar para sua história e buscar compreender seus processos e mutações são atitudes tanto pedagógica como reveladora das escolhas, das concepções, dos referenciais e das diretrizes da extensão que realiza e constrói. É nessa linha o ponto de partida da apresentação “O que está sendo o Motyrum?", no blog do programa:

\begin{abstract}
A breve descrição abaixo do Programa oferece informações não sobre o que é o Motyrum, mas sim o que está sendo. Desde sua criação, há 10 anos (em 2005), o Motyrum vem passando por intensas modificações a cada ano, transformando-se na medida em que transformam-se seus membros e as comunidades que o integram. Esse não é um processo transitório, porém um processo permanente de dinamismo, de construção, desconstrução e reconstrução de seus métodos e objetivos (MOTYRUM, online).
\end{abstract}

Com o intuito de facilitar a visualização do percurso histórico do "Lições de Cidadania", construímos uma linha do tempo do programa.

A linha do tempo é uma estratégia de cronologia que permite relacionar a ocorrência de fatos com o decurso do tempo. Ela permite a organização de dados e informações que são consideradas relevantes para a exploração de determinado assunto por meio de uma técnica de linearização de eventos, facilitando, no âmbito desta pesquisa, a identificação e catalogação dos principais eventos que marcaram o desenvolvimento do programa.

A estratégia de linearização cronológica de eventos ou ocorrências em determinado intervalo de tempo é adotada por diferentes áreas do conhecimento humano e científico. Destacamos, para aprofundamento temático, os estudos realizados por James Ward e William James, em 1890, sobre "linha do tempo", e, no que se refere às suas sub modalidades, os estudos de Richard Bandler e John Grinder, na década de 1970.

Adotamos como termo inicial o seu surgimento em 2005, enquanto atividade do Centro Acadêmico Amaro Cavalcanti (CAAC) do curso de graduação em direito da UFRN, e como termo final a mudança de nome do programa para Motyrum, no contexto de formalização de proposta de extensão para o edital do Programa de Extensão Universitária (PROEXT), do Ministério da Educação (MEC), no ano de 2013.

\footnotetext{
${ }^{26}$ Ao discorrer sobre o ensino e a convicção sobre a mudança social, Paulo Freire desenvolve a ideia de que a História é uma possibilidade, não uma determinação. Afirma, em sua "Pedagogia da Autonomia": "O mundo não é. O mundo está sendo". (FREIRE, 2002, p.85).
} 
A partir dos dados e das informações que foram coletados por meio de análise documental e revisão bibliográfica sobre os oito anos de trajetória do "Lições", foi possível pontuar os marcos que consideramos mais relevantes em relação à sua estrutura organizativa, ao seu campo de atuação e às suas escolhas metodológicas.

Considerando a continuidade da ação extensionista do programa, reformulado em Motyrum, até o ano corrente de elaboração da dissertação, é necessário ressaltar que a trajetória de uma década do programa e os seus vários processos internos e externos de transformação são amplos e complexos, de modo que a linha do tempo elaborada aqui não se pretende exaustiva em relação à história do "Lições de Cidadania", o que demandaria um trabalho de pesquisa exclusivo para tal objetivo ${ }^{27}$. Porém, avaliamos como fundamental dotar a descrição de alguns processos de sua historicidade, para os fins desta dissertação.

$\mathrm{Na}$ dimensão organizativa, o então "Lições de Cidadania" partiu de uma atividade do CAAC, passando a ser projeto de extensão e estruturando-se, hoje, como programa de extensão universitária (o Motyrum) que abarca seis projetos de extensão: o Núcleo Urbano; o Núcleo Rural; o Núcleo Infanto-juvenil; o Núcleo Penitenciário; o Núcleo Indígena; e o Escritório Popular. Em relação ao campo de suas atividades, iniciou atuando em escolas públicas de Natal e hoje atua nas diversas realidades e territórios: comunidades urbanas, assentamentos e acampamentos rurais, comunidades indígenas, unidades de privação de liberdade para adultos e para adolescentes, casos judiciais e extrajudiciais.

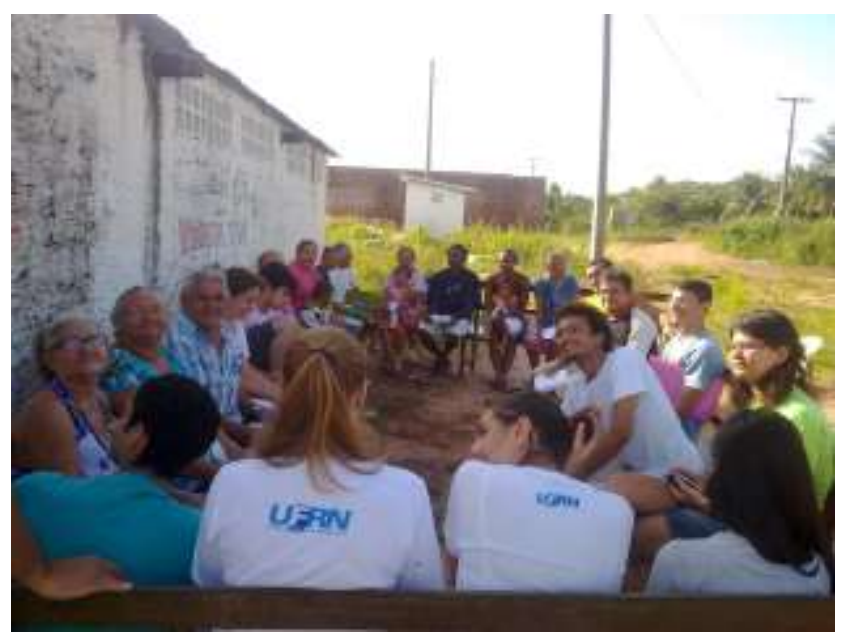

IMAGEM 1: Ação do Núcleo Urbano no Leningrado. FONTE: Arquivos do projeto.

${ }^{27}$ Conferir, a respeito, a dissertação de mestrado em educação desenvolvida por Thiago Matias de Sousa Araújo (ARAÚJO, 2014, p.46-47). 


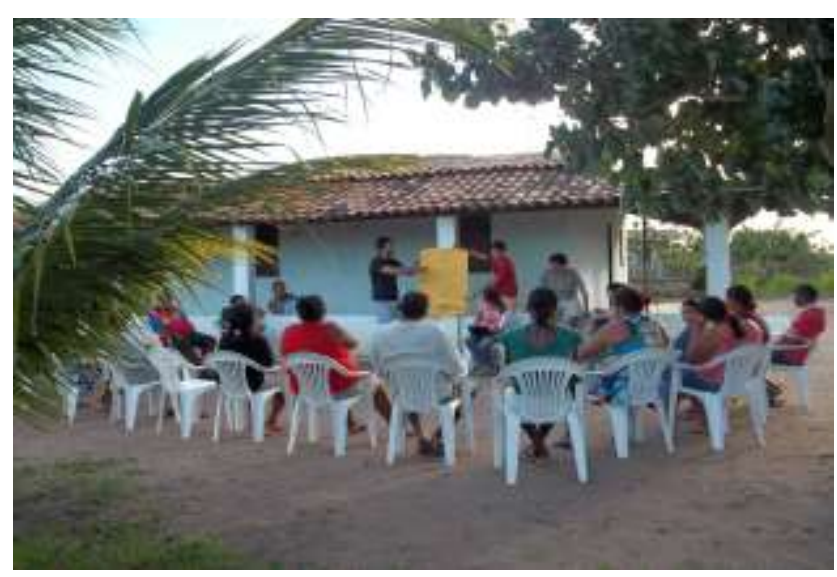

IMAGEM 2: Ação do Núcleo Rural FONTE: Arquivos do projeto

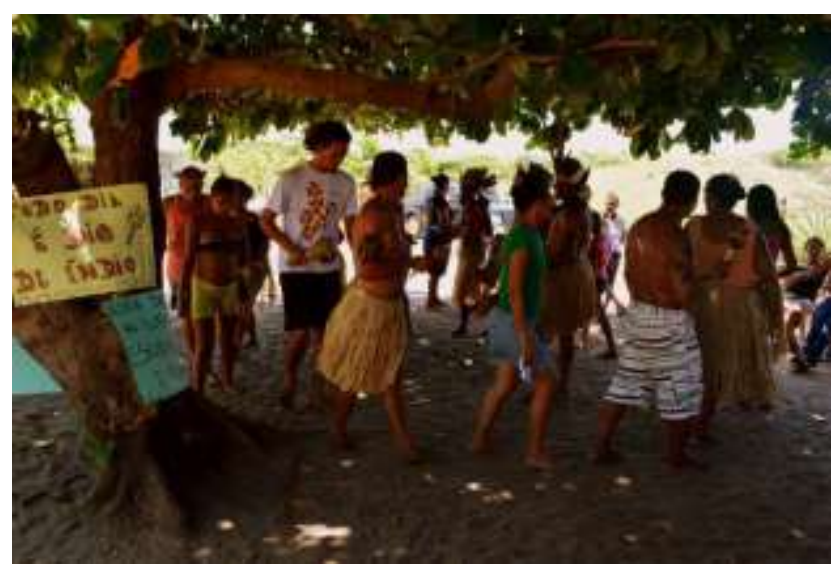

IMAGEM 3: Ação do Núcleo Indígena

FONTE: Arquivos do projeto

No que diz respeito às escolhas metodológicas, o programa iniciou com a adoção de Paulo Freire como seu maior referencial, diretriz assumida até hoje e, no decorrer de seu percurso, debateu as formas de ingresso, de formação, as instâncias internas e os papéis das e dos extensionistas. Não menos importante, são as possibilidades, as oportunidades e os desafios de sustentabilidade ${ }^{28}$, sendo este último um ponto central para a manutenção e estruturação da atividade extensionista e que se revela fundamental para os processos do programa.

\footnotetext{
${ }^{28} \mathrm{~A}$ conjuntura atual do Brasil é de desmonte de políticas públicas em direitos humanos pelo atual governo Temer - e tem se revelado, apesar de poucos meses de gestão, como uma ameaça real a questões como a da sustentabilidade da extensão popular e de projetos de direitos humanos, na medida em que tem promovido corte de orçamento para essas pautas e uma agenda de retrocessos de direitos. Importante mencionar que ainda no governo Dilma já havia medidas de ataque a essas questões, porém, o cenário atual intensificou e potencializou tais danos e tem colocado uma agenda prioritária de precarização de vida de trabalhadoras e trabalhadores. Nesse sentido, indicamos o site "Alerta social: qual direito você perdeu hoje?", cuja existência é emblemática da perda de direitos, literalmente, no cotidiano atual (Conferir <http://alertasocial.com.br/>).
} 


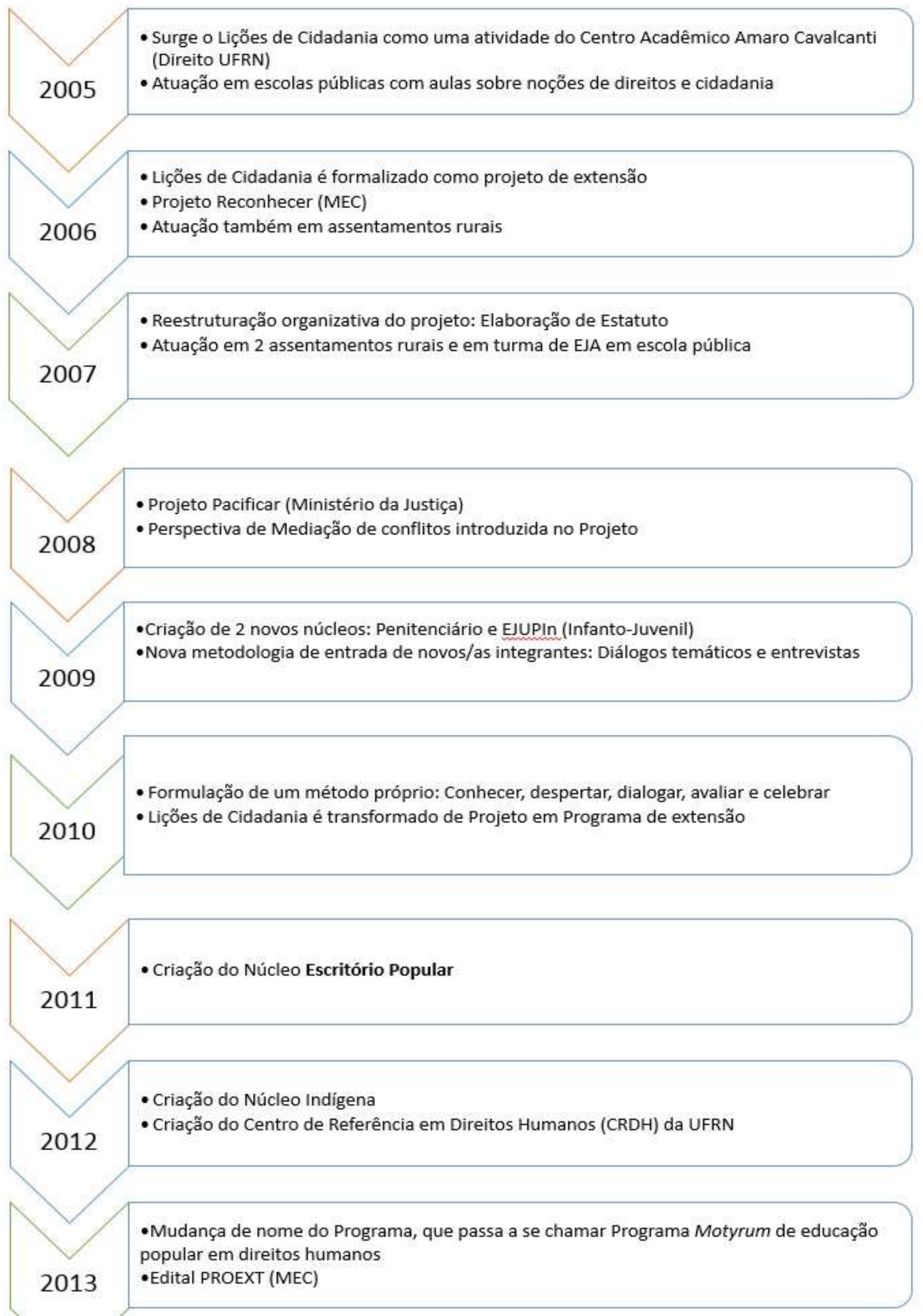

Figura 2: Linha do tempo do Programa de educação popular em direitos humanos Lições de Cidadania, de seu surgimento até a mudança de nome para Motyrum.

Fonte: Elaboração da autora, 2016. 


\subsection{O Lições de Cidadania}

O programa de extensão "Lições de Cidadania" surgiu em 2005, como uma iniciativa do CAAC (ARAÚJO, 2014, p.46), entidade representativa das e dos estudantes do curso de Direito da UFRN, sediado em Natal. Nasceu a partir da constatação e incômodo de que a extensão existente no curso naquele momento prescindia de contato e diálogo popular com a sociedade e da vontade de implementar um projeto de educação em direitos (ARAÚJO, 2014, p.46), conforme explica Caio Vitor Ribeiro Barbosa, advogado, à época graduando em direito na UFRN, integrante do CAAC e um dos fundadores do projeto:

[...] Esse era o cenário de extensão que a gente tinha. Não tinha de fato um contato popular, uma participação com a sociedade, com as pessoas menos providas de recursos principalmente, não existia esse trabalho de conscientização acerca do Direito, da Ordem Jurídica, das garantias previstas na Constituição, não tinha nada disso.

[...] A ideia ainda não estava concebida, ela era de fato um impulso de realmente transformar a realidade, e utilizar o Direito como instrumento de transformação das injustiças sociais. Mas tinha, dentro da sua origem, a questão do respeito às pessoas, aos educandos que seriam destinatários daquela Extensão, ao conhecimento. A gente não tinha a ideia de ser um projeto autônomo, era a ideia de ser um projeto do Centro Acadêmico. [...] Em 2005.2, a gente consegue convencer o Centro Acadêmico a implantar essa iniciativa. [...] Essa primeira iniciativa foi diretamente nas escolas públicas da Grande Natal. A gente escreveu o projeto via PROEX ${ }^{29}$.

Como lembra Caio, o início do "Lições de Cidadania" foi caracterizado pela oferta de aulas em escolas públicas de Natal, mas somente mais adiante o projeto viria a ser formalizado como ação extensionista, em 2006, com a aprovação de proposta submetida ao edital do Programa "Reconhecer", do Ministério da Educação $(\mathrm{MEC})^{30}$, que foi um "Programa de criação de oportunidades de práticas integrais de ensino-pesquisa-extensão para graduandos em Direito" (MINISTÉRIO DA EDUCAÇÃO, 2006a, p.75). O Reconhecer fazia parte do Programa Inclusão e Ações Afirmativas na Educação Superior e visava contribuir para que as faculdades dessem novo significado ao ensino de Direito e construíssem práticas emancipatórias, a partir de uma nova cultura jurídica.

${ }^{29}$ Citação retirada da dissertação de Thiago Matias de Sousa Araújo, referente à entrevista concedida por Caio Vitor Ribeiro Barbosa ao pesquisador. (ARAÚJO, 2014, p.46-47).

30 Conferir a proposta na dissertação de ARAÚJO (2014), disponível online em < https://repositorio.ufrn.br/jspui/handle/123456789/14594>. 
Segundo o Ministério da Educação:

O objetivo do programa é fortalecer a formação cidadã de professores e estudantes, sobretudo na área de direitos humanos. Visa também valorizar e promover o respeito à autonomia e à auto-sustentabilidade das comunidades de afro-descendentes, dos povos indígenas, da população prisional, dos portadores de necessidades especiais e das pessoas que têm 0 vírus HIV/Aids. (MINISTÉRIO DA EDUCAÇÃO, 2006b, online).

Analisando a proposta do "Lições de Cidadania" aprovada pelo edital do Programa Reconhecer, observa-se que o seu objetivo foi de promover formação em direitos humanos, realizando ações para a "democratização do conhecimento jurídico", através de um processo de "alfabetização jurídica popular na área de direitos sociais e humanos" (ARAÚJO, 2014, p.188). Os sujeitos com quem o projeto atuaria seriam de cinco assentamentos rurais no Rio Grande do Norte ${ }^{31}$, membros de associações e alunos e alunas do curso de direito da UFRN, e a perspectiva era de desenvolver uma metodologia que contemplasse a indissociabilidade entre ensino, pesquisa e extensão.

A partir do desafio de planejar a atuação em assentamentos rurais, numa realidade bastante diversa daquela das e dos extensionistas (que era predominantemente urbana), Paulo Freire foi adotado como principal referencial pedagógico-teórico do projeto (escolha mantida até hoje pelo Programa Motyrum). A obra "Pedagogia da Autonomia" foi diretriz para os primeiros passos da práxis do projeto no campo da educação popular em direitos humanos. Como analisa ARAÚJO (2014):

\footnotetext{
Mas, naquele momento, já se apresentavam elementos fundamentais para organização de novas ideias: tinha-se a consciência de incompletude ("que com o Direito só a gente não vai mudar nada"), da diversidade de saberes " (dividia os grupos e estudava Políticas Públicas, Pedagogia, [...] Psicologia"), da inexistência de docência sem discência e da necessária apreensão da realidade.

Esses elementos, além de se fazerem presentes no curso da execução do Projeto, encontram-se também na obra Pedagogia da Autonomia (1996), de Paulo Freire, referência teórica que ganhara centralidade na construção desse novo momento do Lições. (ARAÚJO, 2014, p.57).
}

A atuação nos assentamentos partiu de um levantamento de demandas junto à comunidade e que foi realizado por meio de questionários e conversas, o que gerou um cronograma de encontros contemplando as diversas temáticas elencadas com os sujeitos.

31 Posteriormente, com as dificuldades de operacionalização, a atuação ocorreu, efetivamente, em três assentamentos rurais do estado, segundo Caio Vitor Barbosa, fundador e participante do "Lições de Cidadania", à época, em entrevista a Thiago Matias Araújo (ARAÚJO, 2014, p.57). 
Esse "quefazer" já revela que, desde então, um dos principais eixos estruturantes da teoria freireana, o diálogo ${ }^{32}$, é também elemento fundante da experiência educativa do "Lições de Cidadania". Tal elemento de pensar e agir a partir das demandas, da realidade concreta, é uma das características fundamentais do projeto até hoje (ARAÚJO, 2014) e nos remete à 11aㅡ Tese de Karl Marx e Friedrich Engels sobre Feuerbach, na medida em que coloca como desafio, para além da interpretação do mundo, sua transformação: "Os filósofos têm apenas interpretado o mundo de maneiras diferentes; a questão, porém, é transformá-lo". (MARX; ENGELS, 1984, p.111).

A análise documental realizada durante a pesquisa permitiu a identificação da estrutura organizativa pela qual o "Lições de Cidadania" construiu-se durante o período de execução do projeto aprovado pelo edital do Programa Reconhecer (2006-2007).

No artigo 4ํㅜ do Estatuto de 2007 do "Lições de Cidadania" (ANEXO D), são especificadas três categorias de membros do projeto: alunos membros (pesquisadores, secretariado e extensionistas); professores membros - orientadores (admitidos em função de seu interesse em contribuir com as finalidades do projeto); e membros honorários (estudantes e professores que participaram de edições anteriores do projeto). Para melhor compreendermos o significado das categorias possíveis para "alunos", elaboramos as seguintes definições:

a) os "Secretários" e "Secretárias", estudantes que constituíam o "núcleo central" do projeto, corpo orgânico e permanente que concentrava a capacidade deliberativa e os debates de concepção do projeto;

b) os e as "Extensionistas", estudantes selecionadas e selecionados para participar, exclusivamente, dos momentos de encontros e oficinas com a comunidade; e

c) os "Pesquisadores" e "Pesquisadoras", que não necessariamente participavam dos momentos junto aos assentamentos em que o projeto atuava, mas que eram responsáveis por levantar material de estudo sobre as temáticas das demandas.

Como se pode observar, o princípio da indissociabilidade entre ensino, pesquisa e extensão, apesar de presente na formulação do projeto, não

\footnotetext{
${ }^{32}$ A leitura estrutural da obra de Paulo Freire permite a afirmação de que o diálogo ocupa uma posição central em sua teoria da educação. No mesmo sentido, conferir FREIRE (2011, p.11), FREIRE (2012, p.90), GADOTTI (1996, p. 81; 2007, p.108), GERHARDT (1996, p. 163).
} 
correspondia exatamente à práxis do "Lições de Cidadania" à época. Ao contrário, o projeto se estruturou em torno de uma divisão de papéis reprodutora da divisão social do trabalho que diferencia as que decidem, as que pensam e as que fazem ${ }^{33}$, na medida em que o Secretariado era concebido como a estrutura orgânica permanente e, portanto, espaço de deliberações acerca do projeto, enquanto a participação de extensionistas, pesquisadores e pesquisadoras tinha um caráter temporário em relação a ele, com tarefas específicas.

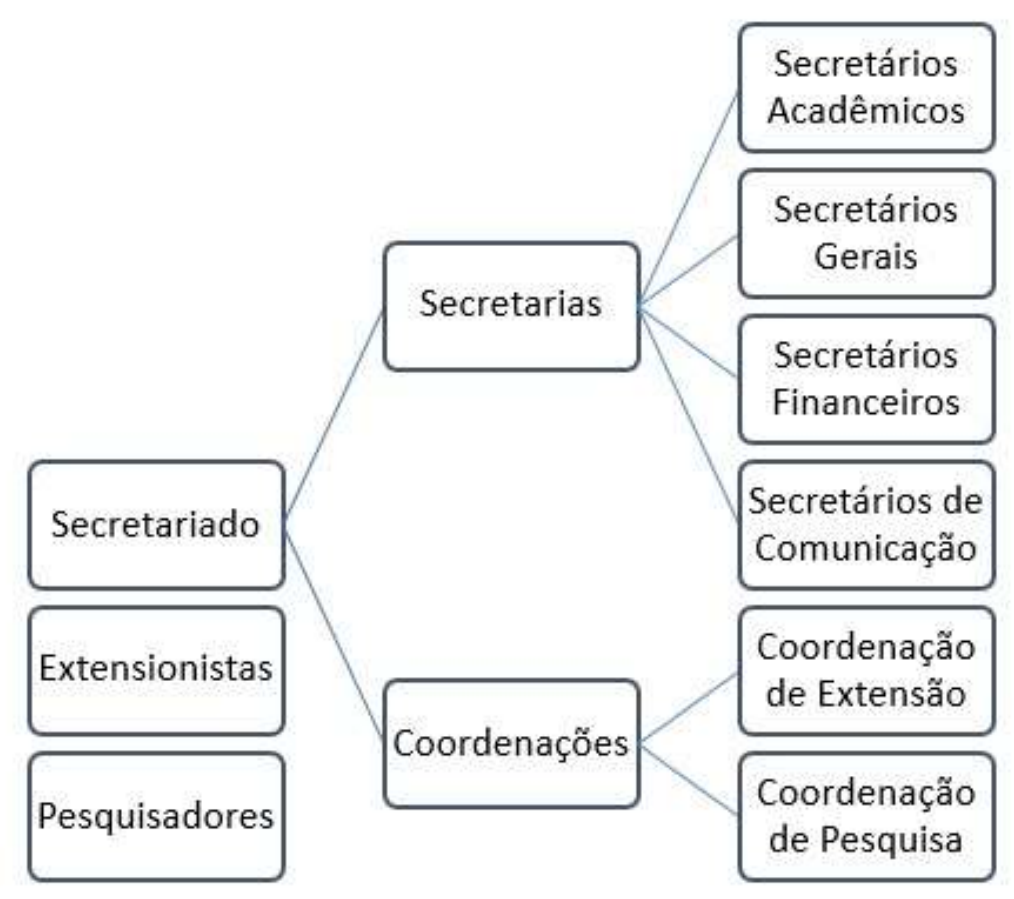

Figura 3: Organograma organizativo do Lições de Cidadania em 2007

Fonte: Elaboração da autora, a partir de adaptação realizada por ARAÚJO (2014, p.78).

Em 2007, com a finalização da proposta que foi aprovada no "Reconhecer" e com a quase totalidade das Secretárias e dos Secretários concluindo a graduação e se afastando da extensão, houve um período de crise e de desarticulação do "Lições" (ARAÚJO, 2014, p.66). Para superar esse momento, foram selecionadas novas e novos integrantes para compor e renovar o "Secretariado", e um dos primeiros esforços coletivos do novo grupo foi o de construir um estatuto (ANEXO D) para organizar as relações e fazeres do projeto (ARAÚJO, 2014, p.74).

É oportuno destacar os objetivos elencados coletivamente, que são reveladores da concepção do projeto àquele momento:

33 "As" refere-se à totalidade dos sujeitos. A escolha aqui é pelo gênero feminino representando o todo. 
Art. $3^{\circ}$ - São finalidades e objetivos do projeto Lições de Cidadania:

a) levar a educação jurídica popular à comunidade como um veículo de transformação e de avanço sócio-político;

b) incentivar o estudo, o ensino, a pesquisa e a extensão no âmbito das áreas de Educação Jurídica Popular, na UFRN;

c) promover a divulgação e o intercâmbio de trabalhos científicos e sociais com outras áreas de Direito e de promoção social, no âmbito do estado do Rio Grande do Norte;

d) desenvolver 0 intercâmbio entre seus associados e pesquisadores filiados a outras sociedades científicas e sociais, nacionais e estrangeiras;

e) realizar reuniões periódicas, destinadas à atualização dos membros e à discussão de problemas de seus interesses;

f) ressaltar a importância do compromisso social, buscando contribuir para que o conhecimento do curso de Direito ultrapasse a questão meramente técnica do aprendizado;

g) promover a cidadania e a educação jurídica popular em todos os âmbitos cabíveis.

Expressões extraídas do Estatuto, que está ainda vigente, tais como "veículo de transformação" (art.3, "a") e "compromisso social" (art.3, "f"), revelam que, desde esse momento, o projeto se reconhece como de educação jurídica popular e propõese a realizar um diálogo para além dos muros da universidade, ideia essa que está diretamente atrelada à própria concepção de extensão. O projeto propõe-se, ainda, a ultrapassar "a questão meramente técnica do aprendizado" (art.3, "f"), disposição essa que nos faz refletir sobre a possibilidade de um horizonte de atuação extensionista que promova a ruptura com a perspectiva liberal de ensino e de processo educativo, e a formação para além da dogmática.

Dialogando com a "Pedagogia da Autonomia", de Paulo Freire, percebemos que o projeto se propõe como alternativa à ideologia fatalista que anima o discurso neoliberal. Este discurso restringe as potencialidades da prática educativa ao apontar somente uma saída para a sua realização, qual seja, a que se destina a:

[...] adaptar o educando a esta realidade que não pode ser mudada. O de que se precisa, por isso mesmo, é o treino técnico indispensável à adaptação do educando, à sua sobrevivência. O livro com que volto aos leitores é um decisivo não a esta ideologia que nos nega e amesquinha como gente. (FREIRE, 1996, p.22).

Além de elaborar o estatuto, o novo grupo do projeto reconfigurou sua estrutura organizativa, de forma a partilhar competências e atribuições, a partir de uma concepção de horizontalidade que formou um corpo deliberativo colegiado, formado por Secretarias e Coordenações (ARAÚJJ, 2014, p.80). Foram, então, criadas as Secretarias Geral, Acadêmica, Administrativa, Financeira e de Comunicação, e as Coordenações de Extensão e de Pesquisa (ANEXO D). 
Segundo o levantamento de informações realizado por Araújo (2014), após a constituição estatutária, o passo seguinte foi estabelecer diálogo com outras áreas, iniciativa tomada a partir da percepção da natureza complexa e interdisciplinar das demandas da atividade extensionista e da própria realidade social. Assim, foi realizado contato com estudantes das áreas de Psicologia, Comunicação Social, Serviço Social, Pedagogia e Engenharia de Produção, resultando na entrada de pessoas de alguns desses cursos no projeto.

Nesse momento de reformulação, o novo grupo fez a escolha por continuar com a atuação em assentamentos rurais, porém em novos assentamentos, mais próximos de Natal do que aqueles em que se deu a atuação no âmbito do programa Reconhecer. Houve, ainda, a decisão de retomar a atuação que deu origem ao "Lições de Cidadania", voltando a atuar na realidade urbana, através de encontros em turmas de Educação de Jovens e Adultos - EJA de uma escola pública do bairro do Bom Pastor, localidade da periferia natalense ${ }^{34}$.

Segundo informações sistematizadas por Araújo (2014, p.86) a partir da análise de atas do programa "Lições de Cidadania", no final de 2007 foi realizada uma seleção de extensionistas através de entrevistas com estudantes interessadas e interessados para atuação nesses dois âmbitos: em assentamentos rurais e em escola pública.

Ao exemplo da metodologia utilizada na execução do projeto que foi aprovado pelo programa "Reconhecer", inicialmente foram contatadas lideranças das comunidades e levantadas demandas junto aos sujeitos dos assentamentos e da escola. Para o cronograma dos encontros nos assentamentos rurais foi escolhido o período de férias do calendário universitário. Dessa forma, as e os extensionistas puderam ir duas vezes por semana, durante os meses de janeiro e fevereiro de 2008, aos assentamentos. Já a atuação na realidade urbana estava condicionada ao calendário de aulas da escola, de maneira que o cronograma de atuação ocorreu entre março e maio, com encontros semanais.

\footnotetext{
34 O Bairro do Bom Pastor surgiu em Natal no fim da década de 1940, no contexto imediato de pós-Segunda Guerra Mundial. Em Natal, por sua localização estratégica, foi instalada base aérea norte-americana no período da Guerra. Encerrada a Guerra e com o retorno dos norte-americanos para os Estados Unidos, foi criada, pela Igreja Católica, uma instituição para acolher as mães potiguares que se tornaram mães solteiras de companheiros norte-americanos. Foi o início do bairro que na sequência deu lugar a uma instituição de internação de adolescentes infratores, a uma instituição de internação de pessoas com Hanseníase e a pessoas que habitavam um lixão da cidade. Atualmente é um dos bairros com grandes índices de violência de Natal-RN.
} 
No segundo semestre de 2008, o "Lições de Cidadania", mais uma vez, concorreu e foi aprovado para um edital do Governo Federal. Dessa vez, para o projeto "Pacificar", do Ministério da Justiça (MJ), o que garantiu novamente uma estrutura mínima de recursos para o desenvolvimento das atividades de extensão.

De acordo com o artigo 2 da Portaria no 1.587, de 29 de agosto de 2008, do Gabinete do Ministro da Justiça, Tarso Genro, o projeto "Pacificar" teve como objetivo implantar, fortalecer e divulgar a mediação, a composição e outras formas de resolução não violenta de conflitos no âmbito das Faculdades de Direito. (MINISTÉRIO DA JUSTIÇA, 2008).

O "Pacificar" agregou à atuação em educação em direitos do "Lições" a perspectiva de mediação de conflitos com o poder público, em uma dimensão de acesso formal à justiça. Nesse sentido, foram incorporadas novas áreas de atuação ao projeto: "Mãe Luiza", bairro da zona leste de Natal/RN originado a partir de ocupações informais e que possui uma trajetória de lutas e resistências pelo direito à moradia na cidade (OLIVEIRA; MAMERI, 2014); o assentamento "Caracaxá", no município de Macaíba, localizado na região metropolitana de Natal/RN; e o assentamento São José de Maxaranguape, em Maxaranguape, município do litoral norte do Rio Grande do Norte (ARAÚJO, 2014, p.99).

Além da incorporação de novas áreas rural e urbana dentro das realidades com que o "Lições de Cidadania" atuava à época, destaca-se a abertura de um novo núcleo de atuação, o Penitenciário, a partir da aprovação no edital do Pacificar, que se propunha a atuar na penitenciária estadual de Alcaçuz (localizado no município de Parnamirim, na região metropolitana de Natal/RN).

Ainda no período de 2007 a 2009, foi constatada uma dificuldade de pais e, principalmente, de mães, em participar das atividades de extensão do projeto, tanto na realidade rural como na urbana, por não terem pessoas com quem deixar seus filhos e filhas. Na tentativa de formular uma resposta a esse problema (na perspectiva freireana, nota-se que houve uma constatação de um problema e a formulação de uma resposta de intervenção na realidade, de modo a saná-lo) foi gerado um quarto núcleo, de Educação Jurídica Popular Infantil (EJUPIn), formalizado em 2009 e desenvolvido com a ideia inicial de cirandas com as crianças das realidades de atuação dos núcleos rural e urbano. 


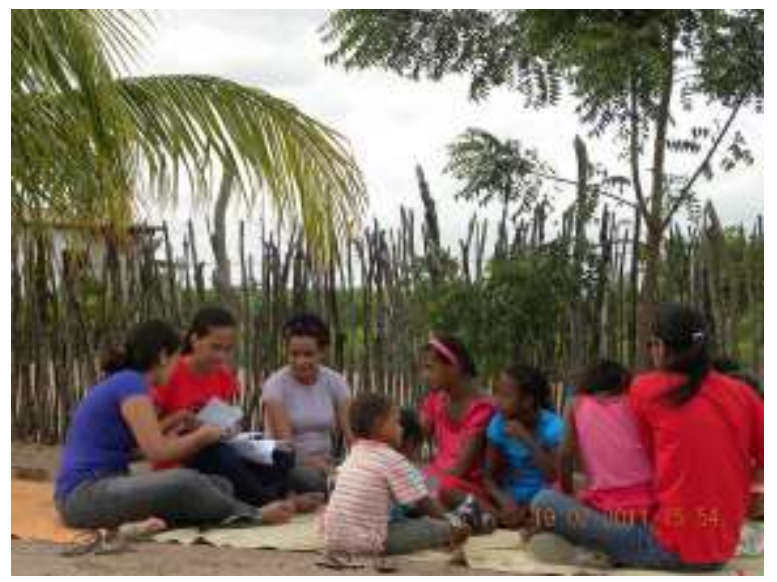

IMAGEM 4: Ação do EJUPIn

FONTE: Arquivos do projeto.

A formulação de uma reação, como o EJUPIn, à provocação realizada diretamente pela realidade e comunidades com as quais o projeto atuava é emblemática para a compreensão de que o programa "é, sendo" e, ainda, da dialogicidade das transformações sofridas e provocadas por ele. Como em uma via de mão dupla, o programa, que pretende intervir para transformar a realidade com a qual atua, abre-se para a sua própria transformação.

Outro ponto que merece destaque foi a mudança do modelo de ingresso de novas pessoas no projeto. Até então o método adotado era o de entrevistas, porém, a partir de 2009, foi incorporada uma nova etapa no processo seletivo de novas e novos integrantes: os diálogos temáticos em grupos de discussão (ARAÚJO, 2014, p.114). A ideia era que cada núcleo do "Lições" promovesse debates sobre temas relacionados à sua atuação, tais como a discussão sobre reforma agrária pelo Núcleo Rural, o Estatuto da Criança e do Adolescente pelo Núcleo Infanto-Juvenil, entre outros.

Esse modelo de ingresso foi aperfeiçoado nos anos seguintes, com a transformação da concepção desse momento para constituir-se como processo de formação inicial para a atuação no projeto. Nesse sentido, em 2010, o projeto (MOTYRUM, online, 2010) explicitou e reafirmou alguns de seus marcos:

O Programa Lições de Cidadania, neste primeiro semestre de 2010, formulou seu processo de formação-seleção de maneira distinta da qual anteriormente havia promovendo, diferenciando-se inclusive das seleções usuais observadas nas práticas extensionistas.

Isto se dá pela constatação de que a admissão de novos membros tendo como base uma entrevista individual de 10, 15 minutos, é incapaz de conhecer a identidade, o compromisso e a identificação com o programa que são necessários para a criação do vínculo aluno-extensão capaz de trazer qualidade à gestão continuada de um ano. 
[...] é necessário que haja continuidade no processo de seleção, sendo necessário também que o candidato conheça de fato as práticas do Programa, os núcleos de atuação onde deseja se inserir e a comunidade carente com quem vai construir o diálogo, para que esteja certo e não desiludido acerca das impressões sobre o Programa.

Sendo assim, o Lições de Cidadania elaborou seu processo de seleção baseado em dois momentos: de formação e de entrevistas.

A primeira etapa constou de oito encontros, aos sábados, das $9 \mathrm{~h} 30$ às $12 \mathrm{~h}$, onde três círculos de cultura eram formados em um mesmo ambiente e os temas e leituras propostos eram debatidos.

Esta formação contou com 53 inscritos, provenientes do curso de Direito, de Serviço Social e de Pedagogia, pois o Programa Lições de Cidadania considera essencial para a boa atuação do projeto na sociedade que haja a interdisciplinaridade.

Foram debatidos, portanto, as seguintes obras, tendo em vista a importância da leitura de Paulo Freire enquanto metodologia do programa: Pedagogia da autonomia (Paulo Freire); Pedagogia da indignação (Paulo Freire); Pedagogia do oprimido (Paulo Freire); Que fazer: teoria e prática em educação popular (Paulo Freire e Adriano Nogueira); Para uma revolução democrática da justiça (Boaventura de Sousa Santos); A universidade no século XXI (Boaventura de Sousa Santos).

Além destas obras, houve dois encontros para debater acerca dos movimentos sociais, com vídeos e textos de diversas fontes acerca da influência da mídia nesta questão polêmica e atual da "satanização dos movimentos sociais". No último encontro, por fim, houve o momento de apresentação de cada núcleo e suas atuações de forma mais específica e contundente.

Posterior a essa fase, onde os secretários do Programa foram os facilitadores das rodas de cultura, houve a entrevista voltada para o interesse de admissão nos núcleos específicos (Urbano, Rural, Penitenciário e EDHUPIN), onde foi considerada a questão da presença e assim do compromisso e apenas quem tivesse ido mais de 5 encontros poderia passar para a segunda etapa.

A entrevista constituiu-se de perguntas gerais acerca das leituras propostas anteriormente e também de temas atuais, como o bolsa-família e a temática das cotas para a democratização do acesso à Universidade.

O ano de 2010 foi marcado por reformulações estruturantes no "Lições de Cidadania": a construção de um método próprio e a transformação do Projeto em Programa de extensão, além da mudança de concepção do modelo de ingresso, conforme já discutido. Cada um desses aspectos não pode ser visto isoladamente, pois ambos conformam um processo de mudança organizativa e conceitual, que guarda marcos freireanos da educação popular em direitos humanos, reafirmando-os, ao mesmo tempo em que pretende avançar a partir dos acúmulos do Projeto até então.

É importante destacar que a elaboração de um método foi feita a partir da descrição da práxis do que o Projeto já fazia (ARAÚJO, 2014, p.106), agregado à influência da perspectiva de participantes do Secretariado que eram oriundos da Renovação Marista (REMAR) ${ }^{35}$. Assim, o método foi formulado a partir do "Ver-

${ }^{35}$ REMAR é um grupo de pastoral jovem cristã que se propõe à ação social. 
Julgar-Agir"36, metodologia localizada e inspirada na teologia da libertação, e adaptado ao que o Lições já fazia então, resultando na construção assim estruturada: "Conhecer, despertar, dialogar, avaliar e celebrar".

Ao contrário de outros processos, não foi uma formulação elaborada para pautar a atuação do Projeto num momento posterior. Foi resultado de um processo de açãoreflexão, de formulação teórica a partir das vivências, como descrevem dois integrantes do "Lições" à época, em artigo apresentado no XVI Seminário de Pesquisa do Centro de Ciências Sociais Aplicadas da UFRN em 2010: "O Programa de Extensão Lições de Cidadania produziu uma metodologia a partir das suas ações que se torna também método de pesquisa, diante da importância da pesquisa de campo e a aproximação com a realidade e as demandas sociais" (BEZERRA; BONAVIDES, 2010, p.7).

Compreendemos que essa concepção metodológica é uma contribuição pedagógica relevante e diferenciada da práxis de extensão popular do "Lições de Cidadania", por isso, destacamos os seguintes trechos que vocalizam a experiência dos integrantes do Projeto à época da concepção do método (BEZERRA; BONAVIDES, 2010, p.7):

\begin{abstract}
A metodologia da Extensão Universitária Popular fundamenta-se essencialmente em cinco momentos: Conhecer, Despertar, Dialogar, Avaliar e Celebrar. Tais momentos não são passos em separado, um momento após o outro; são entrelaçados para o melhor andamento do processo.

O primeiro momento é o Conhecer, em que os extensionistaspesquisadores buscam ter um primeiro contato com a realidade para conhecê-la e dar inicio à criação de um vínculo de confiança com as pessoas. Para isso é necessária a sensibilidade para perceber as especificidades da localidade e, principalmente, humildade, que gera 0 respeito em relação ao espaço de vida.

O segundo momento é o Despertar, a conseqüência do primeiro, pois é conhecendo que despertamos para práticas educativas que realmente transformem a realidade dos sujeitos envolvidos. Aqui cabe destacar que os sujeitos são os estudantes e professores da universidade, como os moradores urbanos, acampados ou assentados rurais, detentos7; todos envolvidos na prática educativa, despertando em comunhão para uma prática política libertadora a serviço de seus espaços.

O terceiro momento, o Dialogar, é a prática desse despertar, com a instrumentalização das soluções aplicadas agora na realidade, através de "aulas", dos momentos de diálogo com a comunidade chamados "Encontros de Cidadania". É o período em que ocorre a transformação do espaço de vida e dos sujeitos envolvidos, tendo capacidade de aprender, não apenas
\end{abstract}

36 Método pastoral localizado no contexto da Teologia da Libertação na Igreja Católica latino-americana. Segundo BOFF (2011), em texto resgatando os quarenta anos da Teologia da Libertação, sobre seu método: "estes são os passos metodológicos da Teologia a Libertação: [...] um ver atento que implica uma análise estrutural dos mecanismos produtores de pobreza-opressão; (4)um julgar crítico seja aos olhos da fé seja aos olhos da sã razão sobre o tipo de sociedade que temos, marcada por tantas injustiças e a urgência de transformá-la; (5) um agir eficaz que faz avançar o processo de libertação a partir dos oprimidos; (5) um celebrar que é um festejar coletivo das vitórias alcançadas. 
para uma adaptação, mas, sobretudo para transformar a realidade, para nela intervir, recriando-a em comunhão. (FREIRE, 1996).

Aqui cabe destacar, mais uma vez, que a metodologia não se dá na forma de etapas, um momento após o outro; são fundamentos práticos em que, por exemplo, para conhecer é preciso dialogar, assim como é possível despertar no diálogo entre os sujeitos.

O quarto momento é o Avaliar, quando é pensada e debatida a continuidade do trabalho e realizada uma análise dos erros e acertos para que, dessa forma, a extensão possa evoluir a cada vez que for aplicada. Também faz parte da avaliação a percepção das ações e articulações da própria comunidade em favor dos seus direitos, quando é posto em prática o que foi construído durante o processo formativo.

E por fim, o quinto momento é o de Celebrar os êxitos junto com a comunidade; é quando os educadores - educandos, todos os sujeitos envolvidos, selam um vínculo, em virtude de tudo que foi vivenciado e transformado ${ }^{37}$.

A mudança de projeto para programa revela elementos conceituais para além da alteração formal: o compreender-se como um programa de extensão universitária integrado por diversos projetos (passando cada núcleo de atuação existente à época a se constituir como um projeto de extensão - rural, urbano, penitenciário, infantojuvenil), e o reconhecimento de sua práxis como sendo de educação popular em direitos humanos, não mais como educação jurídica popular (ARAÚJO, 2014, p.109). Essas transformações registram a importância que a interdisciplinaridade foi assumindo na trajetória do "Lições", manifesta tanto no aumento da entrada de integrantes de outros cursos, como na afirmação do marco de educação popular em direitos humanos, contrapondo-se à perspectiva de educação jurídica popular.

No que se refere aos debates acerca da concepção de extensão universitária, merece menção a participação do "Lições de Cidadania" no I Encontro Nacional de Estudantes de Direito Extensionistas (ENEDEx), realizado em julho de 2010 na Universidade de Brasília (UnB), integrando os debates e construindo o documento final do evento. Destacamos os elementos apresentados no "Manifesto Extensionista" do I ENEDEx como princípios orientadores necessários à extensão em direito nesse documento, elementos esses presentes desde o Estatuto do Lições (2007) e incorporados até a sua práxis atual:

\footnotetext{
Apesar das dificuldades de se definir um conceito exaustivo de extensão, justamente por estar em permanente construção, os/as participantes do I ENEDEx entendem que a atuação em extensão deve ser uma atividade ligada às práticas sociais em que é necessário romper os muros da universidade e democratizar o acesso e o conhecimento nela produzido. Para tanto, a extensão em Direito deve se pautar pelo seguinte conjunto de princípios orientadores:
}

\footnotetext{
${ }^{37}$ Para ver a explicação do método com mais detalhes, recomendamos a leitura do artigo de Hélio Miguel Bezerra e Natália Bonavides, extensionistas graduandos à época de sua elaboração (BEZERRA; BONAVIDES, 2010), hoje advogada e advogado populares do Escritório Popular.
} 
- Sensibilização do/da estudante para a função social e o papel político da universidade e da pratica jurídica, propiciando a organização e o engajamento dos/das estudantes no compromisso com a superação das desigualdades sociais e com o combate às opressões, por meio de uma prática emancipatória e coerente com os princípios dos Direitos Humanos;

- Humanização da racionalidade jurídica, por meio de uma formação orientada pelo exercício da alteridade;

- Construção e fortalecimento da cidadania ativa e engajamento político dos/das atores/atrizes envolvidos/das no processo de construção de novas realidades com a sociedade;

- Fomento da autonomia, da auto-organização e do auto-reconhecimento de grupos sociais;

- Troca e co-produção de saberes e subjetividades por meio de uma construção dialógica e horizontal de conhecimentos entre comunidade e universidade;

- Atuação continuada dos projetos, prezando pela responsabilidade dos compromissos firmados com a comunidade, pelo planejamento e pelo constante repensar das ações;

- Formação transdisciplinar do/a estudante no sentido de desenvolver uma compreensão mais complexa da sociedade e de seus problemas, bem como um olhar critico sobre o ensino e prática do Direito. (MOTYRUM, 2010, online).

Foi também em 2010 que começou a gestação de mais um núcleo do "Lições de Cidadania": o Escritório Popular ${ }^{38}$ (EP). A formalização do EP como projeto de extensão ocorreu somente em 2011, porém, suas primeiras reuniões e processos que o originaram datam ainda de $2010^{39}$.

Em 2011, o "Lições de Cidadania" seguiu com os seus processos de reformulações relevantes, das quais destacaremos duas. No primeiro semestre desse ano, as e os extensionistas do programa propuseram uma nova estrutura de coordenação. Devido a divergências ideológicas, materializadas em diferenças relativas à gestão de recursos, falta de autonomia estudantil, autoritarismo docente e distanciamento do professor coordenador em relação às atividades extensionistas, as e os estudantes do "Lições" deliberaram por debater uma nova configuração coordenativa. Destituíram o professor do curso de direito que coordenava o Programa e formularam uma proposta de coordenação colegiada, que seria formada por professoras e professores de diversos cursos, traduzindo os anseios de horizontalidade, cooperação, interdisciplinaridade e diálogo de saberes do Programa.

O "Lições", que desde a sua origem havia sido coordenado sempre por um professor do curso de direito, passou a ter uma estrutura de coordenação colegiada, formada pelos professores e professoras responsáveis por cada projeto que o

\footnotetext{
${ }^{38} \mathrm{O}$ EP, conforme anunciado desde a introdução da presente dissertação, constitui objeto desta pesquisa e seu surgimento, estrutura e concepções serão tratados nos capítulos 2 e 3 desta dissertação

39 Segundo registros de reuniões e trocas de e-mails, a que a autora tem acesso por ser uma das fundadoras do projeto e integrar essa etapa desde o início.
} 
integrava (núcleo). Além das coordenadoras e coordenadores dos núcleos, contava também com docentes cuja compreensão acerca da extensão e perspectiva ideológica se aproximavam da do Programa. Assim, o novo corpo docente passou a contar com professores e professoras dos cursos de direito, psicologia, ciências sociais, serviço social, comunicação social e pedagogia.

No segundo semestre de 2011, o processo de entrada de novas pessoas passou por um aprofundamento da ideia já adotada no ano anterior, de compreender o momento de seleção para ingresso no Programa como um momento formativo. Nesse sentido, o "Lições de Cidadania", em parceria com o Grupo Multidisciplinar de Projetos de Engenharia e Gestão aplicados ao Desenvolvimento Ambiental e Social (PEGADAS), projeto do curso de Engenharia de Produção da UFRN, lançou o I Curso de Extensão Universidade, movimentos sociais e educação popular. Segundo o edital de convocação de inscrições, o curso:

\footnotetext{
Pensado em três eixos temáticos geradores, já apontados em seu próprio nome, o curso acontecerá em 10 encontros, sendo um por semana, constituídos pelo debate de textos, vídeos, mesas redondas, com o foco na formação construída pela partilha de idéias e descoberta da diversidade. Lembramos ainda que o curso é uma etapa indispensável e obrigatória àquelas e àqueles que desejam ingressar no Programa de Educação Popular em Direitos Humanos - Lições de Cidadania. (MOTYRUM, 2011, online).
}

Identificamos o registro da programação dos dez encontros previstos para 0 Curso, em e-mail enviado para as professoras e professores da coordenação do "Lições", no dia 3 de agosto de 2011, compartilhando a proposta e pedindo contribuições e comentários. Tal registro é revelador do protagonismo estudantil característico do programa, e da extensão universitária de forma geral, na medida em que a concepção, os temas, as leituras e a estrutura do curso foram integralmente formuladas pelas e pelos estudantes. Conforme a mensagem enviada aos e às docentes, segue a proposta do curso (grifos do original):

ENCONTROS:

1. Arte e ecologia dos saberes: a acolhida da diversidade - facilitador Rodrigo Bico (educador e artista).

Inscrição presencial: Apresentação do curso.

2. Violentamente Pacífico: A favor de que? Contra que? A favor de quem? contra quem?

Referencial teórico: Pedagogia da Autonomia; Pedagogia da Indignação; Que fazer? Teoria e Prática.

3. Trabalhar com o Povo.

Referencial teórico: Pedagogia do Oprimido e Como Trabalhar com o Povo (Clodovis Boff).

4. Universidade, o que queremos? 
Desafios para uma universidade libertadora. Facilitadores: Prof. Cipriano e Prof. Walter Pinheiro.

5. Que tipo de extensão? Partilha de experiências dos núcleos do Lições e do Projeto Pegadas das engenharias e que outras experiências de extensão estiverem presentes.

Referencial teórico: Extensão e Comunicação.

6. A favor de que $/ \mathrm{m}$ e contra que $/ \mathrm{m}$ ? Porque existe sem teto e sem terra? As origens dos movimentos sociais e os novos sujeitos sociais (Nordeste).

Mesa-Redonda: prof. Gabriel Vitullo e Marina Santos coordenadora Nacional do MST.

Introdução com os Vídeos de Stédille no canal Livre.

7. EDHUPIN - A favor de que/m e contra que/m? Quem é morto no Brasil? Extermínio das juventudes (ainda em discussão pelo núcleo).

8. Penitenciário - A favor de que/m e contra que/m: Quem é preso no Brasil? (Ainda em discussão pelo núcleo).

9. Pegadas - (temática ainda em discussão pelo projeto).

10.Avaliação e Fechamento do Curso.

O edital com a programação do curso foi divulgado no dia 8 de agosto de 2011, a partir de quando foram abertas as inscrições. Em dez dias, foram realizadas 120 (cento e vinte) inscrições (MOTYRUM, 2011, online) de estudantes de diversos cursos e, também, de outras universidades ou faculdades.

Para ingressar no "Lições" era necessário realizar o curso e passar por entrevistas individuais com uma comissão discente formada por representantes dos diversos núcleos do Lições. Porém, para chegar à fase de entrevistas, era exigido um mínimo de $75 \%$ (setenta e cinco inteiros percentuais) de presença no curso. Essa foi a maneira encontrada para ter controle sobre a participação ao longo dos dez encontros programados e que se revelou, por si só, um método de seleção, considerando que metade dos inscritos atingiu esse índice e passou para a fase de entrevistas (MOTYRUM, online, 2011). Em meados de 2011 o "Lições" contava com cerca de 50 (cinquenta) extensionistas ${ }^{40}$. Esse processo de seleção significou, praticamente, a dobra no tamanho do programa, no que diz respeito ao número de estudantes.

Merece menção, ainda no ano de 2011, a aprovação de projeto da UFRN em edital da então Secretaria de Direitos Humanos da Presidência da República $(\mathrm{SDH} / \mathrm{PR})^{41}$ para implementação de um Centro de Referência em Direitos Humanos (CRDH), que começou a funcionar em 2012 em Natal. Destacamos esse fato porque extensionistas do "Lições de Cidadania" construíram a proposta enviada ao edital em parceria com extensionistas do Observatório da População

\footnotetext{
40 Segundo registros do "Lições de Cidadania" junto à PROEX, disponíveis em <www.sigaa.ufrn.br>.

${ }^{41}$ Edital no 01/2011, da SDH/PR.
} 
Infanto-Juvenil em contextos de violência (OBIJUV) ${ }^{42}$, não sendo por acaso a presença de um marco de educação popular em direitos humanos sintonizado com as diretrizes do Lições e, conforme veremos no capítulo 2, porque a instituição de um $\mathrm{CRDH}$ na Universidade desempenhou um papel relevante também no que diz respeito à sustentabilidade do Escritório Popular.

Em 2012 surgiu um novo núcleo no Programa, o indígena, como fruto da aproximação de estudantes do "Lições de Cidadania" com uma comunidade indígena em Sagi (município localizado no litoral sul do Rio Grande do Norte) e do diálogo e parceria com Luciano Falcão, advogado da Rede Nacional de Advogados e Advogadas Populares (RENAP) que atuava com povos indígenas do RN.

A partir da constatação das inúmeras demandas de acesso à justiça na comunidade e da sua especial situação de vulnerabilidade, agravada pelo fato do RN ter sido um dos dois últimos estados brasileiros a reconhecer seus povos indígenas (o que revela a omissão do Estado em relação a essa população), as e os extensionistas do núcleo se propuseram a atuar com a metodologia de educação popular em direitos humanos naquela comunidade. Assim, temos a formação do sexto Núcleo do Lições de Cidadania, estrutura que se mantém até o presente momento ${ }^{43}$.

Encerrando o resgate sobre as transformações por que passou o Programa, destacamos o processo de mudança de seu nome, ocorrida em 2013. Essa alteração foi resultado de um longo processo de debates e do incômodo com a distância entre a concepção freireana de educação popular do "quefazer" do "Lições de Cidadania" e seu nome, revelador de uma concepção de educação bancária, em que há hierarquia de saber entre os sujeitos, em que falta horizontalidade, em que não há dialogicidade. Assim, segundo a Nota do Programa Motyrum sobre a mudança de nome (Anexo $A$ ):

\footnotetext{
42 "O Observatório da População Infanto-Juvenil em Contextos de Violência (OBIJUV) surgiu em 2009, no âmbito da Universidade Federal do Rio Grande do Norte (UFRN), com a proposta de aproximar a academia da realidade de crianças e adolescentes/jovens do estado, por meio de projetos de pesquisa e extensão nessa temática. Apresenta, nas ações, um novo modelo de relação entre esse público-alvo e a sociedade. Conta com cerca de trinta membros, dentre professores, graduandos, pós-graduandos e colaboradores externos, e é parceiro de outros projetos da UFRN que lutam pela garantia de direitos humanos, tais como o Programa Motyrum e o Centro de Referência em Direitos Humanos (projetos de extensão)". (OBIJUV, online).

43 Desde então, os projetos de extensão que integram o Programa são os núcleos rural, urbano, penitenciário, infanto-juvenil, Escritório popular e indígena.
} 
Nomear um coletivo, portanto, não é mera exigência estética, está relacionado com a identidade do grupo, com a sua ação. Por isso, os homens e mulheres que vem construindo conjuntamente o Programa de Educação Popular em Direitos Humanos Lições de Cidadania sentiram a necessidade de dar uma nova pronúncia ao coletivo. "Lições de Cidadania" já não é o nome que identifica a nossa práxis e, por isso, não é suficiente para a construção de nossa identidade.

O nosso coletivo nasceu como um meio de combate às opressões no mundo, e tem o objetivo de transformar a universidade e o saber produzido por ela em um instrumento dos oprimidos e das oprimidas, pois fazemos a opção política pelos esfarrapados e esfarrapadas do mundo, que têm sua palavra silenciada.

Embora o termo cidadania possa ser ressignificado, como Augusto Boal busca fazer em suas obras, é preciso fazer um contorcionismo hermenêutico para justificar o "Lições" de Cidadania de uma maneira progressista e libertadora.

A Nota, ao anunciar a mudança do nome do Programa, revela também não apenas seus elementos constituintes, como também os seguintes elementos de análise de sua concepção de extensão universitária, tais como:

a) o objetivo do Programa: "[...] transformar a universidade e o saber produzido por ela em um instrumento dos oprimidos e das oprimidas" (MOTYRUM, 2013, online);

b) os sujeitos com quem o Programa atua: "[...] fazemos a opção política pelos esfarrapados e esfarrapadas do mundo, que têm sua palavra silenciada" (MOTYRUM, 2013, online);

c) sua perspectiva interdisciplinar e sua composição: "[...] ampliou seus campos de atuação; conseguiu acolher estudantes e professores de diversos cursos; conta com a participação ativa de 6 advogados que passaram pela extensão popular; tem extensionistas ocupando diversos espaços críticos e atuando diretamente com os movimentos sociais" (MOTYRUM, 2013, online); e

d) sua escolha política: "[...] uma identidade, de uma palavra popular, feminista, negra, indígena, da juventude, dos oprimidos, dos condenados da terra, condenados do mundo e da história, que indicasse nossa opção lúcida e consciente pelos explorados e exploradas, pela libertação das correntes opressoras. (MOTYRUM, 2013, online).

Por fim, pontuamos um último marco na construção da linha do tempo do "Lições". Na Figura 3 fizemos referência à aprovação de proposta do Motyrum em edital do PROEXT 2013, do MEC. Isso porque ao observar a trajetória de mais de uma década do "Lições de Cidadania" e Motyrum, percebemos a centralidade ocupada pelas possibilidades de sustentabilidade para a extensão universitária. Nesses quase 11 (onze) anos de existência do Programa, as oportunidades de 
recursos propiciadas por projetos aprovados em editais do Governo Federal (como o "Reconhecer" e o PROEXT, do MEC, o "Pacificar", do MJ, e o edital do CRDH, da $\mathrm{SDH}-\mathrm{PR}$ ), foram determinantes para a continuidade do Lições e de suas atividades, na medida em que os recursos foram principalmente utilizados para custear bolsistas de graduação e materiais usados em atividades de educação popular.

Destacamos que a questão do financiamento é estruturante para a extensão universitária por pelo menos duas razões principais: i) promoção de condições de sustentabilidade e ii) influência sobre escopo, delimitação e outras escolhas centrais da ação extensionista. No que diz respeito ao primeiro aspecto, a possibilidade de assistência estudantil para o desenvolvimento das atividades (com a garantia de bolsas de extensão, por exemplo) e o fomento em relação a condições objetivas para ações que pretendem ultrapassar os muros da universidade (relacionadas a transporte, materiais para as atividades de educação popular, etc.) revela-se, quase sempre, como determinante para a implementação de projetos e programas de extensão. Sobre o segundo elemento, a possibilidade de custeio de ações extensionistas com aprovação de propostas em editais, ao mesmo tempo em que se constitui como oportunidade de resposta à questão anterior, pode ter também como resultado uma influência sobre a agenda do projeto que se pretende realizar. Isso porque muitas vezes a necessidade de captar recursos leva a projetos de extensão se adequarem a temas e perfis exigidos por tais editais. No caso do Lições de Cidadania, como veremos, temos um exemplo concreto dessa questão, na medida em que o "Pacificar" foi responsável pela introdução da atuação com mediação no Programa.

Dessa forma, reconhecemos como avanço os editais publicados pelo Governo Federal no período analisado para o Lições (2005 a 2013), tendo em vista a competência desse ente no que diz respeito ao fomento da extensão universitária. Olhando para o caso concreto do Lições (e, mais adiante, do EP), verificamos que se constituem como importantes marcos para a promoção e garantia de direitos humanos e do tripé universitário de ensino, pesquisa e extensão, constitucionalmente previsto. Porém, avaliamos de forma negativa a descontinuidade dessas iniciativas, ainda que apareçam como pontuais, como sendo uma característica que constitui uma lacuna e configura um problema persistente no campo das políticas públicas voltadas à extensão universitária. $\mathrm{O}$ desafio de se enxergar e se tratar a extensão universitária com fomento permanente, como política pública contínua, ainda é enorme, sobretudo 
se compararmos os recursos destinados à extensão com aqueles destinados à pesquisa universitária e ao ensino superior brasileiro.

A nosso ver, a lacuna de se deixar de tratar políticas de direitos humanos e de extensão universitária como tais - e mantê-las num patamar máximo de programas e ações pontuais e/ou esporádicas, o que se revela ao observarmos a política de fomento em curso, é característica de governos com forte cunho neoliberal e desenvolvimentista, cujas agendas são pautadas por uma formação tecnicista e profissionalizante voltadas ao mercado. A perspectiva emancipatória que deveria nortear esses eixos - políticas de direitos humanos e de extensão - e tê-los como prioritários demonstra-se, assim, com grandes lacunas ${ }^{44}$.

A Constituição da República Federativa do Brasil, de 5 de outubro de 1988, dispõe, em seu artigo 207, que "As universidades gozam de autonomia didáticocientífica, administrativa e de gestão financeira e patrimonial, e obedecerão ao princípio de indissociabilidade entre ensino, pesquisa e extensão". Apesar do princípio constitucional da indissociabilidade caracterizar o "quefazer"/ethos universitário, no cotidiano fica evidente que existe concretamente uma espécie de hierarquização entre essas três dimensões, em que a extensão universitária muitas vezes ocupa mais um não-lugar (aquilo que não é ensino e nem é pesquisa) do que um lugar tão relevante quanto os outros dois pilares.

A extensão é uma ação universitária com potencial para permear a universidade de função social, pois é desenvolvida a partir do diálogo permanente com a realidade. É nesse sentido a fala de E4, que ao refletir sobre a contribuição do Lições para sua formação, revela o potencial humanizante da extensão universitária e a importância de que seja fomentada como instrumento de transformação para estudantes, mas também para a própria instituição:

\footnotetext{
${ }^{44} \mathrm{Em}$ que pese nossa análise crítica referente aos governos Lula e Dilma Rousseff, à frente do Brasil no período aqui analisado, não podemos deixar de externar grande e especial preocupação com a atual conjuntura do país, que enxergamos como golpe à democracia em curso. Se nossa avaliação é de grandes lacunas relacionadas às políticas de direitos humanos e de extensão universitária no governo Dilma, o governo Temer tem sinalizado para o completo desmonte de tais políticas e o aprofundamento acelerado de uma agenda em aliança com as elites empresariais - nacionais e internacionais, vide os projetos de total precarização das condições de trabalho, com ataques à previdência e à CLT, a extinção do Ministério das Mulheres, Igualdade Racial e Direitos Humanos e seu rebaixamento ao status de Secretarias, o corte de recursos e suspensão da celebração de novos convênios no âmbito dessas pastas dentro do Ministério da Justiça, entre inúmeros outros retrocessos tão significativos já nos primeiros poucos meses desse governo interino.
} 
Pessoalmente, né? Isso aí foi pro profissional. Pessoalmente... você tem contato com pessoas, que sempre foi a carência que eu tinha pra dar sentido àquilo tudo; de você sentir que você só faz uso do seu conhecimento, da sua contribuição ali como jurista, mais especificamente como alguém que tá ali disposto a contribuir quando você entende o que aquilo significa pro dia da pessoa, pro dia a dia, pra realidade, pra família dela...seja garantindo que eles não levassem uma surra dentro da câmara, seja pensando em ter energia elétrica dentro da casa, coisas que pra minha realidade nunca existiram as omissões, as carências...então você, quando....pessoalmente isso me ajuda a compreender melhor; existencialmente, assim, falando do papel aqui, qual o papel do conhecimento que eu tenho, como ele deve ser utilizado e pra quem. Então é uma formação mais humanista também. Você se distancia da mera leitura do caderno processual, você se distancia da leitura da lei, passa a olhar a janela como a realidade. Então pra mim esses dois aspectos foram muito fortes. Eu entendo que a nossa presença na universidade...a universidade lapida a gente e a gente lapida ela também; a gente contribui muito pra formação dela. (E4)

Portanto, garantir sua sustentabilidade é "contribuir para que a Extensão Universitária seja parte da solução dos grandes problemas sociais do País" (2012, online, p.5), como afirma a Política Nacional de Extensão Universitária (FORPROEX, online, 2012), elaborada pelo Fórum de Pró-Reitores de Extensão das Universidades Públicas Brasileiras (FORPROEX).

Não por acaso o tema dos modelos de financiamento da Extensão esteve entre os principais debates da última edição do Encontro Nacional do FORPROEX, ocorrido em novembro de 2015 em João Pessoa, no Estado da Paraíba, em cujo documento final, o Fórum afirma:

O FORPROEX, diante dos desafios de avançar na construção de modelos para a efetiva implementação da inserção da extensão nos projetos pedagógicos dos cursos de graduação das Instituições Públicas de Ensino Superior, em cumprimento à estratégia 7 , da meta 12 , do Plano Nacional de Educação (PNE) e, ainda, da necessidade de ampliação dos programas de desenvolvimento de políticas de financiamento da extensão, considera que para a consolidação da Extensão Universitária é necessária a constituição e aperfeiçoamento de políticas e instrumentos de fomento e apoio à Extensão Universitária com a capacidade de impulsionar a integração da extensão no âmbito das IES públicas, entendendo que estas temáticas são articuladas e indissociáveis. (FORPROEX, online, 2015).

A tentativa de construir uma linha do tempo ateve-se à possibilidade e necessidade de resgatarmos um pouco da historicidade do programa a fim de localizar de onde, como e por que surgiu a experiência do EP, núcleo que abordaremos daqui em diante. Para uma descrição e análise mais rica e detalhada sobre a constituição e construção do "Lições de Cidadania" e Motyrum, a partir de seus processos educativos, recomendamos a dissertação de mestrado de Thiago Matias de Sousa Araújo (ARAÚJO, 2014), doutorando em educação na UFSCar e egresso do programa. 


\title{
CAPÍTULO 2 O “QUEFAZER” DO ESCRITÓRIO POPULAR: uma experiência de extensão universitária em direito e em direitos humanos
}

\author{
É difícil defender, \\ Só com palavras, a vida. \\ João Cabral de Melo Neto, 2000.
}

Como ensina Moacir Gadotti (1996, p.83) ao apresentar a proposta de pedagogia dialógica e educação libertadora em Paulo Freire, em concepção de educação parte-se sempre de um contexto concreto para, então, responder a ele.

A partir dessa compreensão é que se constrói o processo educativo do projeto de extensão intitulado Escritório Popular (EP) do Programa Motyrum de Educação Popular em Direitos Humanos da Universidade do Rio Grande do Norte (Motyrum). Sua concepção de educação, de direito e de direitos humanos ${ }^{45}$ parte do contexto concreto de criminalização de lutas por direitos, que assume diversos formatos no âmbito do sistema de justiça ${ }^{46}$, e das demandas de sujeitos "semdireitos" por assessoria jurídica para lidar com essas tentativas de bloqueio e negação de acesso à justiça.

Ao falarmos em "criminalização de lutas por direitos", no âmbito do sistema de justiça, não nos referimos, restritamente, aos processos criminais. Referimo-nos aos processos mais amplos de cerceamento das lutas, tais como os processos de reintegração de posse em casos de ocupações rurais e urbanas, que reivindicam as reformas fundiária, os processos envolvendo a omissão do Estado no que diz respeito à garantia de políticas públicas para sujeitos historicamente oprimidos, dentre outros processos que tratam de tentativas de bloqueio da luta política protagonizada por sujeitos coletivos de direito.

Nesse sentido, recorremos ao conceito de criminalização de Loïc Wacquant (2003), que é desenvolvido a partir de uma concepção de "criminalização da miséria" (WACQUANT, 2003, p.19). O autor explica que na América, durante as décadas de 1960, 1970 e 1980, houve uma "[...] substituição progressiva de um (semi) Estadoprovidência por um Estado penal e policial, no seio do qual a criminalização da

\footnotetext{
${ }^{45}$ As concepções de direito e de direitos humanos serão objeto de análise no capítulo 3, no qual, ainda, serão abordadas as questões do "bloqueio" e do "acesso" à justiça.

46 O sistema de justiça é maior que o Judiciário e, de acordo com Maria Tereza Sadek (2010, p.9), é composto pela Advocacia, Defensoria Pública, Ministério Público, Polícia, Cartório e o próprio Judiciário. Aqui consideramos relevante que os processos de criminalização são também ecoados pelo Executivo, pela mídia e pela própria Universidade.
} 
marginalidade e a 'contenção punitiva' das categorias deserdadas faz às vezes de política social" (WACQUANT, 2003, p.19 e 20). Este Estado seria caracterizado por:

\begin{abstract}
Seu lado social e os benefícios que distribui são cada vez mais monopolizados pelos privilegiados; sua vocação disciplinar se afirma principalmente na direção das classes inferiores e das categorias étnicas dominadas. Este Estado-centauro, guiado por uma cabeça liberal montada sobre um corpo autoritarista, aplica a doutrina do 'laissez faire, laissez passer' a montante em relação às desigualdades sociais, mas mostra-se brutalmente paternalista a jusante no momento em que se trata de administrar suas consequências. (WACQUANT, 2003, p.20 e 21).
\end{abstract}

Com isso, notamos a diferença entre criminalidade e criminalização, sendo este último relacionado à concepção prévia do potencial criminoso e àquele ao fenômeno penalmente tipificado. Assim, quando nos referimos à criminalização de movimentos sociais remetemos a uma lógica estabelecida que guarda estreita relação com uma ideologia que enxerga os movimentos sociais e suas ações como potencialmente criminosas, muito embora não estejam previamente previstas como tipos penais. Trata-se, portanto, de uma criminalização seletiva que atende a interesses específicos colocados pelo poder político e econômico.

Tomando como referência essa compreensão freireana de que o processo educativo parte de uma realidade concreta, é fundamental situar o tempo-espaço e os indivíduos históricos com e por quem esse processo é realizado. Assim, neste capítulo pretendemos historicizar e analisar a experiência de extensão universitária em direito e em direitos humanos do EP, tendo em perspectiva sua identificação como um núcleo de assessoria jurídica universitária popular. Para tanto, desenvolvemos uma linha do tempo do projeto $^{47}$ (tempo-espaço), que foi fruto da pesquisa de campo (entrevistas e grupo focal) e da análise documental (grupo de e-mails do EP, projetos registrados junto à Pró-Reitoria de Extensão da UFRN, relatórios e peças) realizada na pesquisa acadêmica. Também apresentamos uma revisão bibliográfica acerca das assessorias jurídicas universitárias populares, pois identificamos a "assessoria jurídica popular" como categoria de análise para a experiência do EP.

\footnotetext{
47 Foi necessário estabelecer um recorte temporal para as análises desta pesquisa. Dessa forma, consideramos aqui a trajetória do Escritório Popular de seu surgimento e formulação, em 2010, até o início de 2015, ano em que realizamos a pesquisa de campo. Destacamos que a construção de uma linha do tempo do projeto foi uma demanda dos sujeitos entrevistados para esta pesquisa e, portanto, é nesse sentido que não poderia deixar de ser incorporada a ela, a partir da perspectiva deste trabalho de se constituir como contribuição ao "quefazer" do projeto aqui analisado.
} 
Ao traçar a caminhada do EP desde o seu surgimento, elencamos e analisamos alguns de seus elementos estruturantes, incluindo o seu "quefazer", e identificamos o projeto no marco de O Direito Achado na Rua (ODANR). Identificamos os sujeitos com os quais atua como sendo os "oprimidos" (FREIRE, 2012), os sujeitos "sem-direitos" (DUSSEL, 2001) que se constituem como "sujeitos coletivos de direito" (SOUSA JUNIOR, 2008), ou seja, como indivíduos históricos com e por quem o processo educativo é realizado. Nesse mesmo sentido, identificamos no EP uma concepção de educação em direitos humanos forjada também como reação às limitações do modelo tradicional de Núcleo de Prática Jurídica e de ensino jurídico.

\subsection{Localizando no tempo-espaço: a caminhada do Escritório Popular}

Apesar de ter sido uma das fundadoras (2010) e membras do EP (2010 e 2011), além de ter integrado o "Lições de Cidadania" no período de 2010 a $2012^{48}$, compreender o processo de formação do EP exigiu o esforço de um novo olhar sobre a realidade observada. Foi como montar um quebra-cabeça de um desenho cuja figura sabe-se, previamente, o esboço, sem que, com isso, se conheça os encaixes de cada peça. Cada sujeito entrevistado, cada documento analisado na pesquisa trouxe-me peças novas. Peças estas que, por vezes, aparentavam grandes semelhantes entre si e que, porém, um olhar atencioso revelava algum detalhe que as diferenciava das demais, proporcionando o seu encaixe no todo e ia ajudando a decifrar a imagem maior.

Tanto pela análise das falas dos sujeitos entrevistados, como pela análise documental, ficou evidente que os fatores que provocaram a criação do núcleo EP foram múltiplos. Localizar o seu surgimento e o seu desenho exige, portanto, a visualização de contextos específicos locais da época. Porém, ao formarmos a imagem maior do quebra-cabeça, pudemos analisar que tais contextos colocados como específicos num primeiro momento, constituíam-se em representativos de contextos gerais de cursos de direito e de conjunturas de lutas por direitos no Brasil.

\footnotetext{
48 Integrei como extensionista o Programa Lições de Cidadania a partir de 2010. Porém, já acompanhava sua atuação, mas sem integrá-lo organicamente, desde 2008, quando cheguei a participar de atividades de formação, visitas a assentamentos rurais e comunidades em que os núcleos rural e urbano do Programa atuavam.
} 


\subsubsection{Montando um quebra-cabeça: juntando as peças que formaram o Escritório Popular}

No primeiro capítulo descrevemos a trajetória do programa de extensão universitária em que está inserido o EP. A escolha por apresentarmos o "Lições de Cidadania" e o Motyrum deveu-se à ligação direta entre os seus processos e os elementos que provocaram o surgimento do EP. Como vimos, a aprovação de proposta do "Lições" no âmbito de edital do projeto "Pacificar", do Ministério da Justiça (2008), introduziu uma nova perspectiva ao Programa, até então inexistente em seu "quefazer", a de mediação. A ideia era partir da educação popular em direitos humanos com as comunidades e, ao identificar violações de direitos (por ação ou omissão do Estado), facilitar processos de mediação entre o poder público e as comunidades, com vistas a buscar uma resolução das questões.

Uma das comunidades acompanhadas pelo "Lições de Cidadania" no âmbito do projeto aprovado no edital do "Pacificar" foi o assentamento rural "Caracaxá", no município de Macaíba, localizado na região metropolitana de Natal/RN. Dois problemas urgentes foram apresentados pela comunidade às e aos extensionistas: a ausência de coleta regular do lixo e a ausência de abastecimento de água ao assentamento. O primeiro caso era agravado pela solução forçada de incinerar o lixo, o que acarretava em danos ambientais para a própria comunidade, gerando um novo problema a ser resolvido. O segundo era agravado porque, apesar de não haver fornecimento de água encanada, a companhia de abastecimento de água do estado enviava faturas de cobrança para os agricultores e agricultoras, que tinham receio de que, em caso de não pagamento pelo serviço que não era ofertado, seus nomes fossem inscritos no cadastro de dívidas e ficassem impossibilitados de serem beneficiados com a concessão de crédito rural para agricultura familiar. Estavam colocadas, portanto, duas questões coletivas para assessoria jurídica.

Nesse mesmo período, em agosto de 2009, os centros acadêmicos dos cursos de Direito, de Comunicação Social e de História da UFRN criaram o Observatório da Câmara ${ }^{49}$, projeto cujo objetivo era monitorar a Câmara Municipal de Natal/RN e cujas principais atividades ocorreram em torno do debate sobre o transporte público coletivo da capital potiguar. Parte das e dos integrantes do Observatório da Câmara integrava

\footnotetext{
${ }^{49}$ Registro sobre o início do projeto pode ser conferido no blogue do CAAC. Disponível em: <http://caac-
} ufrn.blogspot.com.br/2009/08/observatorio-da-camara.html>. Acesso: 11 abr. 2016. 
também o "Lições de Cidadania" e o CAAC, o que revela, de certa forma, como a dimensão de compromisso e engajamento político com a realidade da cidade se constituíam também como causa e consequência da formação desses espaços ${ }^{50}$.

A participação no Observatório da Câmara provocou as e os estudantes a pensar em possibilidades jurídicas para as questões coletivas relacionadas aos temas de mobilidade urbana e se constituiu como uma das sementes que viria a originar o Escritório Popular no ano seguinte, conforme explica E1 ${ }^{51}$ :

[...] o embrião do Escritório Popular foi bem antes, acho que em 2008 ou foi 2009, eu lembro que eu conversava muito com E2 em relação a essa necessidade de ajuizar ações coletivas. [...] E nesse mesmo período eu não sei se você lembra do Observatório da Câmara que a gente fundou [...]. A gente chegou a estudar a possibilidade de ajuizar uma ação contra o aumento das passagens por falta de publicidade. [...]. Acho que surgiu nesse contexto de Observatório da Câmara, de aumento das passagens, é, de a gente ter pago ${ }^{52}$ Direito Processual Coletivo lá com Ronaldo ${ }^{53}$ e disso, né, eu acho que o embrião, a semente, do Núcleo do Escritório Popular, do Núcleo voltado pra pegar demandas coletivas originárias de outros núcleos eu acho, na minha opinião, que surgiu mais ou menos aí, nesse contexto.

Cabe destacar, também, como é possível se observar na trajetória do "Lições de Cidadania" apresentada no primeiro capítulo, que nessa mesma época, entre 2009 e 2010, o "Lições" estava num processo de estreitamento de laços com movimentos sociais. O referencial freireano de atuação despertou as e os extensionistas para que os assentamentos e comunidades em que o programa atuaria fossem escolhidos não pelas universitárias e universitários, mas pelos movimentos sociais, como sujeitos daquelas realidades de negação de direitos (ARAÚJO, 2014).

Assim, como etapa preparatória das novas atuações, havia diálogos entre extensionistas e integrantes de diferentes movimentos sociais organizados e em organização, como o Movimento dos Trabalhadores Rurais Sem Terra (MST) ${ }^{54}$, no

50 Para mencionar outros elementos que consideramos úteis para ilustrar essa dimensão: nesse período, havia uma intersecção relevante de integrantes do Lições de Cidadania e CAAC, de forma que escolhas como a de fazer alianças com movimentos sociais foi compartilhada por ambos os espaços, bem como a organização de debates sobre problemas da realidade social local e nacional, a participação em manifestações políticas e atos de sujeitos sem-direitos, etc.

51 Por questões éticas, escolhemos desidentificar as pessoas e entrevistas realizadas nesta pesquisa. Para tanto, numeramos as pessoas entrevistadas utilizando uma letra e número de identificação ( $E 1$, E2, E3, E4, E5, E6, E7 e E8), cuja correspondência somente a pesquisadora conhece.

52 A expressão "pagar disciplina" faz parte da linguagem informal utilizada por estudantes da UFRN e tem como sinônimo "cursar disciplina", não tendo nenhuma relação com o pagamento de qualquer quantia.

${ }^{53}$ Referência ao professor Ronaldo Pinheiro de Queiroz, professor do curso de direito da UFRN.

54 "O Movimento Sem Terra está organizado em 24 estados nas cinco regiões do país. No total, são cerca de 350 mil famílias que conquistaram a terra por meio da luta e da organização dos trabalhadores rurais. 
caso da atuação na realidade rural, e do Movimento de Luta em Bairros, Vilas e Favelas (MLB) ${ }^{55}$ ou de associações comunitárias ${ }^{56}$, em determinado momento da atuação em realidades urbanas.

Esse momento era onde as e os extensionistas apresentavam ao movimento a proposta de um trabalho de educação popular em direitos humanos, apresentavam o programa e o movimento social indicava em que assentamento(s) e em que comunidade(s) urbana(s) seria mais necessário atuar (ARAÚJO, 2014). E esse momento se tornou também uma oportunidade para os movimentos apresentarem demandas por assessoria jurídica, uma vez que estavam com estudantes majoritariamente do curso de direito, mas deparavam-se com a limitação do programa de não atuar nesse âmbito:

[...] quando era Lições nós fazíamos um trabalho de educação em direitos humanos, educação popular em direitos humanos. Nas comunidades, a primeira coisa que perguntavam quando a gente ia se apresentar dizendo que éramos estudantes de direito, que tínhamos um projeto, era se a gente tinha assessoria jurídica. Isso foi muito marcante porque foi uma quebra de expectativa grande, porque a gente teve um início do Lições de ir para as comunidades, assentamentos. [...]. Aí a partir daí a gente todo empolgado nessa nova perspectiva naquela época, nova perspectiva do Lições, em trabalhar junto com os movimentos sociais, quando a gente apresentou pro MST o trabalho de educação em direitos humanos, assim, o que a gente era, aí eles falaram, "Mas, vem cá, vocês fazem assessoria?". [...]. Foi nossa, o primeiro contato com Cícero ${ }^{57}$ que eu tive foi ele perguntando se a gente fazia assessoria jurídica. Não falou nem... não deu nem "Bom dia" direito! E aí foi a frustração, mas era o que tinha pra hoje e acabou fazendo

Mesmo depois de assentadas, estas famílias permanecem organizadas no MST, pois a conquista da terra é apenas o primeiro passo para a realização da Reforma Agrária." (MST, online).

55 "O Movimento de Luta nos Bairros, Vilas e Favelas (MLB) é um movimento social nacional que luta pela reforma urbana e pelo direito humano de morar dignamente. Somos um movimento formado por milhares de famílias sem-teto de todo o país vítimas da ação predatória da especulação fundiária e imobiliária. Acreditamos que a reforma urbana é um meio, um instrumento; ela faz parte da luta maior da classe trabalhadora para construir uma sociedade diferente, com igualdade, dignidade e direitos para todos: a sociedade socialista. Para o MLB, a luta pela moradia é o motor principal da luta pela reforma urbana, pois através dela conseguimos mobilizar milhares de pessoas, pressionar os governos e chamar a atenção para os problemas enfrentados pelo povo pobre nas grandes cidades. Nesse sentido, tem importância fundamental a organização e realização das ocupações. A ocupação educa o povo para a necessidade de lutar organizado e desenvolve o espírito de trabalho coletivo. Ocupar é um ato de rebeldia, de confronto com a ordem estabelecida, de questionamento à sagrada propriedade privada capitalista. Logo, enquanto morar dignamente for um privilégio, ocupar é um dever!" (MLB, online).

56 "Pode-se definir associação como pessoa jurídica de direito privado sem fins lucrativos, criada a partir da união de ideias e esforços em torno de um propósito lícito e comum." (MPMG, 2010, online, p.4). E ainda: "As associações comunitárias ou de bairro são aquelas que têm como objetivo organizar e centralizar forças de moradores de uma determinada comunidade para representar, de maneira mais eficaz, interesses comuns." (MPMG, 2010, online, p.4).

57 Cícero é integrante do MST/RN que à época se reuniu com as e os extensionistas. Atualmente é estudante de direito da segunda turma de direito do Programa Nacional de Educação na Reforma Agrária (PRONERA), turma Elizabeth Teixeira, na Universidade Estadual de Feira de Santana, na Bahia. A turma é formada por movimentos sociais camponeses e populares, provindos de 11 Estados brasileiros (Movimento de Pequenos Agricultores - MPA, online). 
aliança [...]. Mas foi isso, assim, lá no Patativa ${ }^{58}$ a gente fez e aí teve essa frustração. E aí outros casos como Dulce em Mãe Luíza ${ }^{59}$, quando a gente foi pra Mãe Luíza, Dulce também, professora Dulce da Arquitetura, fazia essa... não pressão, mas fazia essa pergunta, que de uma certa forma me incomodava... (E2)

Durante as entrevistas realizadas na etapa de campo desta pesquisa, outra peça revelou-se igualmente fundamental para que a ideia de criar um núcleo que fizesse assessoria jurídica se materializasse: o encontro com a Rede Nacional dos Advogados e Advogadas Populares (RENAP).

Segundo E2, "[...] quando a gente foi [ao Encontro da RENAP], a gente voltou convicto de que tinha que fazer Escritório Popular, convicto!".

A RENAP foi criada em 1995, em resposta a um cenário de inúmeros conflitos e de violência no campo, crescente criminalização e repressão dos movimentos sociais, sobretudo do MST (GORSDORF, 2004, p.145; TAVARES, 2007, p.68; CARLET, 2010, p.45). Junto ao MST, a Comissão Pastoral da Terra (CPT) foi uma das provocadoras da articulação que originou a referida rede (TAVARES, 2007, p.63). Trata-se de uma rede de articulação nacional de advogados e advogadas populares, descentralizada, horizontal, sem hierarquia e que tem por objetivo "dar suporte técnico, agilizar e otimizar a prestação da assessoria jurídica aos movimentos sociais e resgatar a utopia da advocacia voltada para os interesses das classes populares" (Cadernos RENAP no6, 2005, p.105). Sua dinâmica de funcionamento tem em sua centralidade a realização de encontros presenciais anuais e um grupo virtual nos quais advogados e advogadas, das cinco regiões do Brasil, podem trocar experiências, decisões judiciais, peças e outras formas de cooperação no "quefazer" da assessoria jurídica popular (TAVARES, 2007).

A CPT sistematiza, desde 1985, e lança uma publicação anual com os dados referentes aos conflitos no campo no Brasil. Analisando seus relatórios, verificamos o intenso quadro de violência no campo no país, conforme a tabela abaixo. Sistematizamos na tabela os dados relativos aos anos de 1995, 2010 e 2015, por serem, respectivamente, o ano de criação da RENAP, o de surgimento do Escritório Popular e o de publicação do relatório mais recente disponibilizado pela Comissão.

\footnotetext{
58 O Centro de Formação, Capacitação e Treinamento Patativa do Assaré é um espaço do MST, localizado no município de Ceará Mirim/RN, onde foi realizada a reunião entre o movimento e as e os extensionistas do Lições de Cidadania, por volta de 2010 (ARAÚJJ, p.122).

59 "Mãe Luiza" é uma comunidade urbana de Natal/RN em que o Lições de Cidadania atuou.
} 


\begin{tabular}{|c|c|c|c|}
\hline \multicolumn{5}{|c|}{ Conflitos no Campo no Brasil (Dados da CPT) } \\
\hline \multicolumn{5}{|c|}{ Violência contra Posse e Propriedade } \\
\hline & $\mathbf{1 9 9 5}$ & $\mathbf{2 0 1 0}$ & $\mathbf{2 0 1 5}$ \\
\hline № de conflitos de Terra & 441 & 853 & 998 \\
\hline Vítimas de Despejo judicial & 12.832 & $*$ & ** \\
\hline \multicolumn{4}{|c|}{ Violência contra a Pessoa } \\
\hline № total de conflitos & $\mathbf{1 9 9 5}$ & $\mathbf{2 0 1 0}$ & $\mathbf{2 0 1 5}$ \\
\hline Pessoas envolvidas & 554 & 1186 & 1.217 \\
\hline Assassinatos & 381.086 & 559.401 & 816.837 \\
\hline
\end{tabular}

*Referente ao ano de 2010, não foi informado o número de vítimas de despejo judicial. Porém, foram registrados os números relativos às famílias expulsas (1.216) e despejadas (8.067).

** Referente ao ano de 2015, não foi informado o número de vítimas de despejo judicial. Porém, foram registrados os números relativos às famílias expulsas (795) e despejadas (13.903).

Figura 4: Conflitos no Campo no Brasil.

Fonte: Elaboração da autora, a partir de dados da CPT.

Ao lançarmos um olhar analítico para a tabela, observamos duas questões reveladoras do intenso grau de conflitos no campo brasileiro: a grande ocorrência de violências contra a posse, a propriedade e a pessoa, e a permanência desse cenário de conflitos no decorrer do tempo. Tais elementos refletem a concentração fundiária agrária no Brasil e a ausência de um amplo processo de reforma agrária no país. No sítio dos "Dados e textos sobre a Luta pela Terra e a Reforma Agrária", portal que agrupa vasto acervo de pesquisas, dados e publicações sobre a questão agrária brasileira e que é executado pela UnB, temos, que:

Segundo o Censo Agropecuário de 2006/IBGE o grau de desigualdade fundiária no território brasileiro, entre os anos de 1975 a 2006, permaneceu praticamente inalterado; o índice de Gini registrado para 2006 foi de 0,856; não muito diferente do mesmo índice para os anos 1995, 1985 e 1975 que foram, respectivamente, 0,857; 0,858 e 0,855 (REFORMA AGRÁRIA EM DADOS, online).

Foi nessa conjuntura de graves e numerosos conflitos que surgiu a RENAP.

Em 2009, extensionistas do "Lições de Cidadania" que integravam o CAAC, durante uma palestra do professor José Geraldo de Sousa Junior na UFRN ${ }^{60}$, intitulada

${ }^{60}$ Registro da palestra: "'Direito achado na rua ou na lei?' é o tema da palestra ministrada pelo reitor da Universidade de Brasília (UnB), Prof. Dr. José Geraldo de Sousa Júnior, formado em Ciências Jurídicas e Sociais. Promovido pelo Centro Acadêmico Amaro Cavalcante (CAAC), o evento acontece nesta sextafeira (25/09), às 9h, no auditório do Centro de Ciências Exatas e da Terra (CCET). O Direito achado na rua 
"Direito achado na rua ou na lei?"61, foram convidadas e convidados para participar de um Encontro da RENAP que ocorreria semanas depois em Fortaleza, no Estado do Ceará. Nesse período, já havia o incômodo e a percepção de que as demandas por assessoria jurídica dos movimentos sociais não poderiam ser ignoradas, sobretudo por um programa que se reconhecia (e se reconhece) como freireano.

Foi na RENAP que houve o encontro das e dos extensionistas do "Lições" com outras experiências e trajetórias de assessoria jurídica a movimentos sociais. Esse encontro encantou os extensionistas e os fez ter a convicção de que o desafio da assessoria jurídica era difícil, porém, possível:

\begin{abstract}
Então, a gente, a priori, não pensava em fazer assessoria jurídica, e aí, a gente encontrou Daniel Valença ${ }^{62}$ numa palestra de José Geraldo e ele comentou com a gente que ia ter esse encontro em Fortaleza de advogados populares, que a gente mal tinha ouvido falar, tinha ouvido falar pouco, e pegamos uma carona com Luciano Falcão63 [...]. Fomos para o encontro da Confederação do Equador, da RENAP Nordeste, que foi onde a gente, não vou dizer que a gente conheceu Daniel Pessoa ${ }^{64}$ lá, mas a gente só conhecia meio que de vista, entendeu? Aí acabo citando os sujeitos, mas dá pra entender que a ideia é explicar o processo: que foi no encontro da RENAP, que estava eu e E2, acho que foi a primeira vez que a gente teve a perspectiva mesmo de que dava pra trabalhar com direito, direito mesmo [risos], como advogado, como advogada, e trabalhar junto de comunidade, trabalhar com o povo, trabalhar com movimentos sociais. A gente voltou alucinado desse encontro! Voltou alucinado! (E3)
\end{abstract}

As mesmas impressões de E3 são reafirmadas na entrevista de E2, que também participou daquele encontro da "Confederação do Equador"65:

faz parte do Núcleo de Estudos para a Paz e Direitos Humanos e objetiva ir além do legalismo ao procurar o direito no espaço público, nas reivindicações do povo. A linha de pesquisa é o encontro dos Novos Movimentos Sociais e o Direito." (RIBEIRO, 2009, online).

${ }^{61}$ Mais uma vez é possível perceber a organicidade entre o "Lições de Cidadania" e o CAAC, revelada aqui pelo referencial comum adotado do Direito Achado na Rua, cujo material subsidiava as formações do programa de extensão e que era a escolha assumida pelo CAAC em debates realizados, como é o caso dessa palestra de setembro de 2009 e da escolha do professor José Geraldo de Sousa Júnior para aula inaugural do ano letivo de 2010 para o curso de direito da UFRN. Conferir: http://caacufrn.blogspot.com.br/2010/02/iii-aula-magna-do-curso-de-direito-da.html. Acesso: 12 abril 2016.

62 Daniel Valença é professor do curso de direito da Universidade Federal Rural do Semi-Árido (UFERSA), no RN, egresso do curso de direito da UFRN e integrante da RENAP.

${ }^{63}$ Luciano Falcão é advogado popular no RN, assessor jurídico de comunidades indígenas do estado e integrante da RENAP.

64 Daniel Pessoa é advogado popular, integrante da RENAP e atualmente professor do curso de direito da UFERSA. Viria a se integrar ao EP como advogado colaborador a partir do caso da ocupação da Câmara Municipal de Natal, movimento popular denominado "Fora Micarla" e que foi acompanhado pelo projeto em junho de 2011.

${ }^{65}$ A "Confederação do Equador" é como se autodenomina a articulação de advogados e advogadas populares integrantes da RENAP e que estão no Nordeste do país. Além de participar dos encontros nacionais anuais da RENAP, as e os integrantes da "Confederação do Equador" realizam encontros periódicos próprios. 
[...] a gente não sabia o que queria ser quando crescer, mas voltou convicto. Lá a gente conheceu a advogada de Maria da Penha. A gente conheceu os advogados da Bahia que tinham barrado a transposição do São Francisco, que é Duda ${ }^{66}$ e afins. Enfim, a gente conheceu Noaldo ${ }^{67}$, enfim, a gente conheceu uma galera que foi muito importante assim e hoje são nossos exemplos na advocacia e tal. A gente conheceu essa galera. Não tinha como não voltar assim. E aí a gente voltou muito convicto. Tinha que fazer algo (grifo nosso). (E2).

Encontrar as mesmas angústias, preocupações e desafios, mas também a mesma vontade de usar o direito para as causas populares, a aliança com movimentos sociais, conhecer experiências de advocacia popular atuando com conflitos em diferentes realidades do Brasil, foi essencial para o surgimento do Escritório Popular, conforme apontam as entrevistas.

Neste ano de 2016, em que a RENAP celebra seus 21 anos, é fundamental o resgate da importância dessa Rede para as lutas no Brasil, a relevância da possibilidade de participação de estudantes de direito nos encontros da Rede, a construção, a partir da práxis, de um direito que atua pela emancipação social do povo brasileiro.

É importante destacarmos outro elemento que, embora não seja central, consideramos relevante em nossas análises por constituir um dos fatores que contribuiu para a criação do Escritório Popular, que é o fato de as e os estudantes que deram início ao núcleo estarem, à época, no último ano da graduação em direito. Essa informação torna-se relevante não em si mesma, mas por potencializar algumas questões.

A primeira é a de que a proximidade do término de um ciclo (graduação) por parte de alguns integrantes do Lições de Cidadania e a consequente provocação que esse momento traz consigo acerca da escolha sobre os rumos profissionais a serem tomados desafiavam alguns estudantes a pensar em como usar a formação em direito para continuar atuando com movimentos sociais e sujeitos sem-direitos. A segunda é que nesse período do curso é que estão as disciplinas do Núcleo de Prática Jurídica $(\mathrm{NPJ})^{68}$, sendo por meio dele 0 atendimento a casos concretos (com nomes e rostos associados a processos). A terceira é que também nesse momento final do curso que alguns dos estudantes cursavam a disciplina de direito processual coletivo, o que aliado aos outros tantos fatores já elencados (demandas coletivas oriundas do "quefazer"

\footnotetext{
${ }^{66}$ Duda é Carlos Eduardo Chaves, advogado popular, integrante da RENAP e da Associação de Advogados de Trabalhadores Rurais no Estado da Bahia (AATR).

${ }^{67}$ Noaldo Belo Meireles é advogado popular da Comissão Pastoral da Terra (CPT) na Paraíba, integrante da RENAP, associado da Dignitatis Assessoria Técnica Popular e membro titular da Comissão Permanente Defensores de Direitos Humanos e Enfrentamento da Criminalização dos Movimentos Sociais do Conselho Nacional de Direitos Humanos.

${ }^{68}$ Trataremos, posteriormente, do Núcleo de Prática Jurídica, suas limitações e formulações.
} 
extensionista, fosse pela atuação de educação popular em direitos humanos, fosse pelas demandas dos movimentos sociais) colocou-se como provocação a pensar o direito a partir de um paradigma diferente do apresentado ao longo de todo o curso ${ }^{69}$.

Percebemos, portanto, que o contexto de criação do Escritório Popular é múltiplo e precisa considerar elementos do ensino jurídico da UFRN, da extensão universitária realizada pelo "Lições de Cidadania", da conjuntura local e suas demandas:

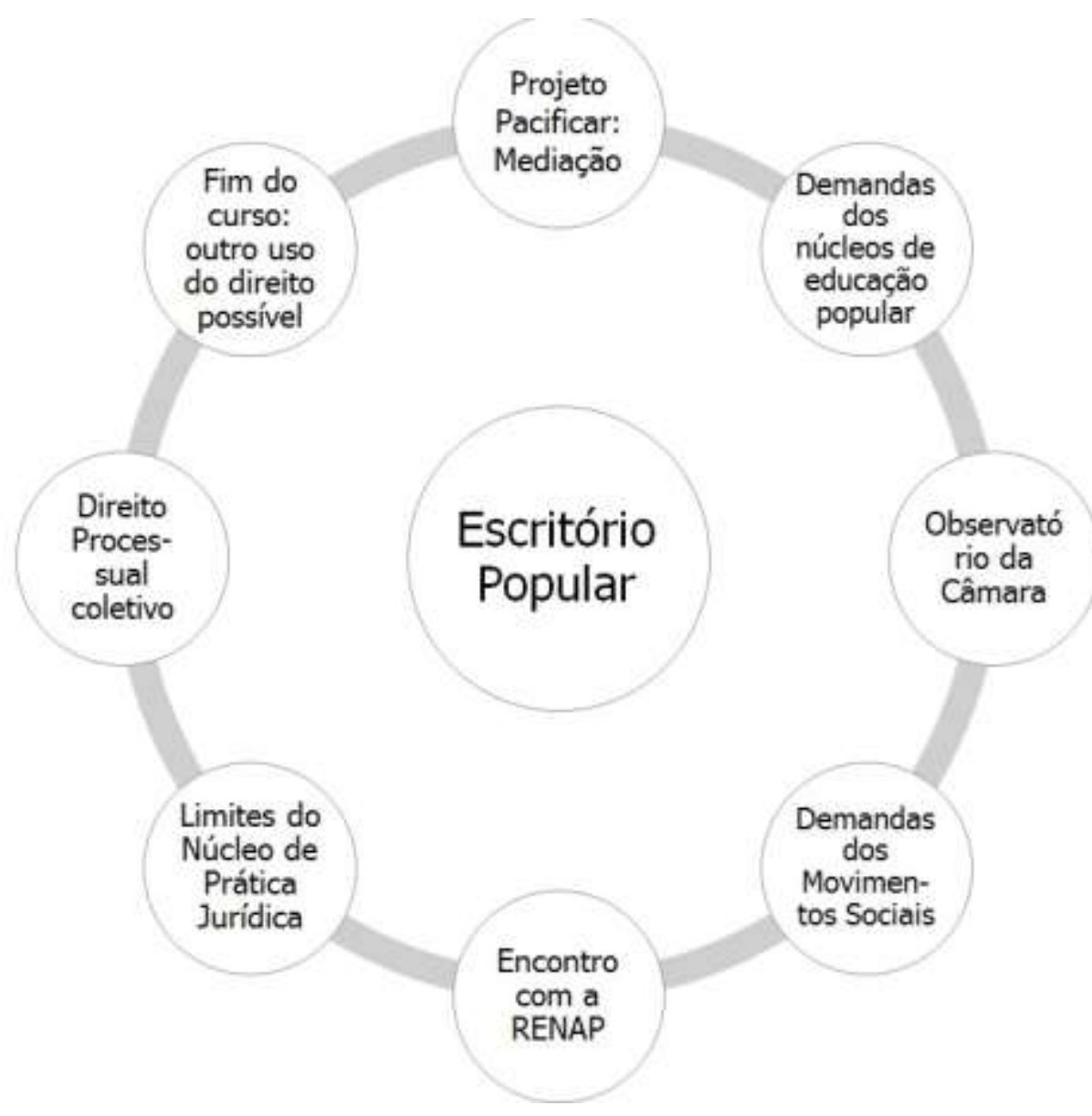

Figura 5: Elementos geradores do Escritório Popular Fonte: Elaboração da autora, 2016.

À primeira vista, o quebra-cabeça montado pode dar a impressão de que suas peças são exclusivas da realidade potiguar, do curso de direito da UFRN e/ou daquele período temporal. Porém, um olhar mais cuidadoso mostra que essa realidade é comum tanto aos cursos de direito como um todo, no que diz respeito às concepções predominantes de direito e dos Núcleos de Prática Jurídica (NPJ), como ao cenário de violações de direito do país, desde uma perspectiva histórica. Isso

69 Abordaremos o paradigma dominante e hegemônico das concepções tradicionais de direito, de direitos humanos e o deslocamento de paradigma provocado pelo "quefazer" do Escritório Popular, no capítulo 3. 
porque, por exemplo, o contexto do aumento das passagens de transporte público e manifestações em torno das tarifas e da mobilidade urbana é nacional - tendo originado, inclusive, movimentos como o Movimento Passe Livre (MPL) e sido uma das faíscas provocadoras das manifestações de junho de 2013 no Brasil. O mesmo ocorre com os NPJs, cujo perfil de atendimento a casos individuais e distanciamento de problemas sociais coletivos é o padrão nacional.

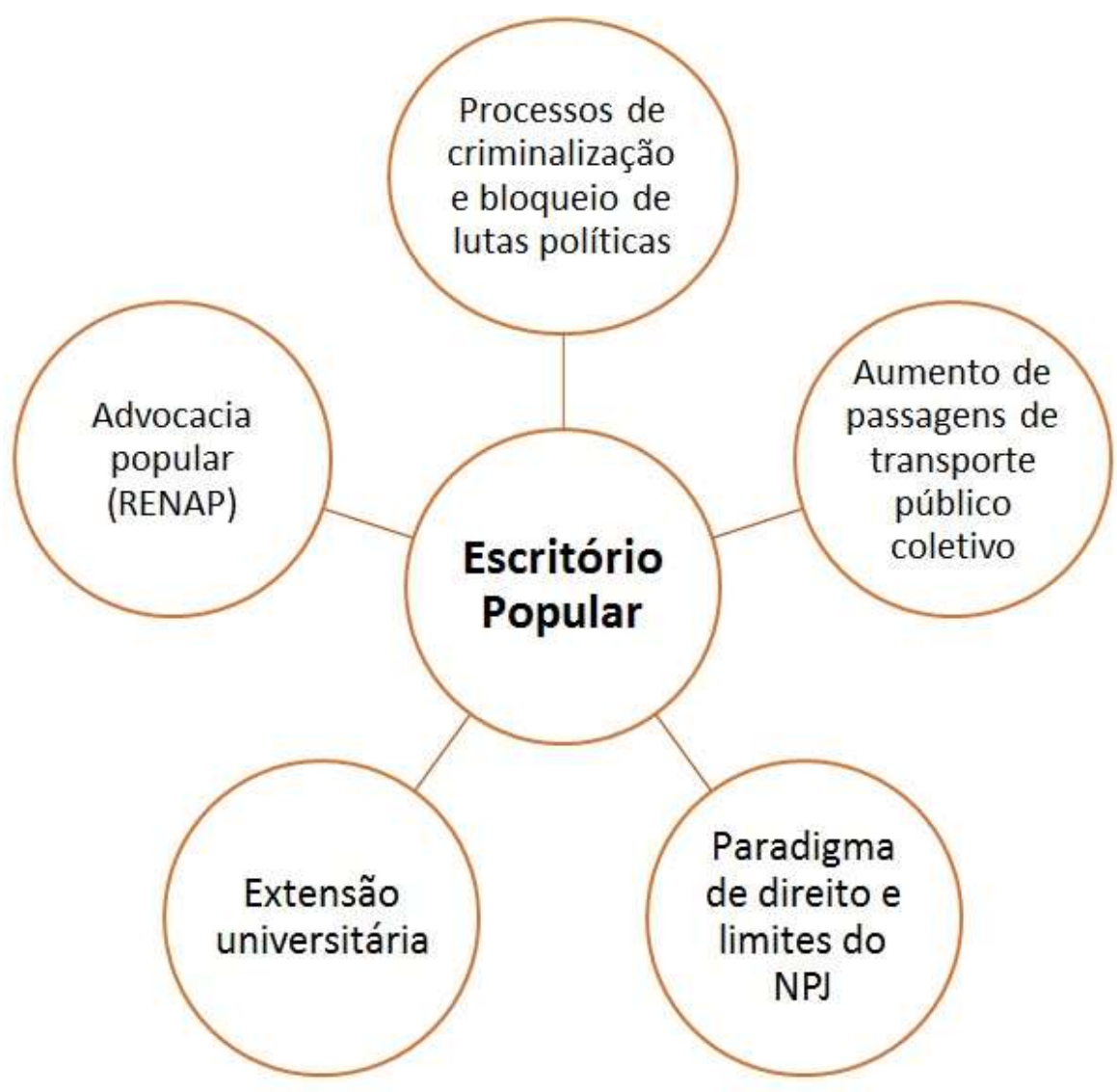

Figura 6: Elementos provocadores da criação do Escritório Popular, presentes para além do contexto do RN.

Fonte: Elaboração da autora, 2016

Temos, portanto, que apesar das aparentes especificidades do cenário que provocou a criação do Escritório Popular, suas motivações são gerais e presentes no país como um todo. Nossa análise desse contexto de formação do projeto é de que a conjuntura de lutas políticas e o paradigma dominante de direito (ambos elementos comuns à realidade do Brasil e dos cursos de direito), mediatizados pela experiência de extensão universitária e de advocacia popular do EP, provocam uma reação de deslocamento do paradigma de direito para uma perspectiva coletiva, de direitos humanos, em permanente diálogo com a realidade social, com 
intencionalidade política anunciada de aliança com sujeitos sem-direitos e movimentos sociais, o que entendemos aqui como uma dimensão pedagógica de democratização da justiça. A resposta criativa em que se forja o EP constitui-se como processo educativo transformador e emancipatório, na medida em que possibilita essas rupturas e deslocamentos.

\subsection{Da concepção popular que permeia o "quefazer": de sem-direitos e oprimidos a sujeitos coletivos de direito}

Uma questão central na configuração e no "quefazer" do EP é a que adjetiva como "popular" o nome do projeto e que diz respeito aos sujeitos com quem o EP atua. No capítulo 1, antecipando algumas de nossas análises sobre os sujeitos com quem é construída a práxis extensionista do Motyrum, apresentamos duas compreensões possíveis e complementares para o elemento "povo" contido na ideia de "popular": a concepção de Fidel Castro (1979, p.45), que é centrada na "massa oprimida" submetida historicamente a injustiças; e a de Enrique Dussel (1986, p. 97), com a perspectiva gramsciniana de "bloco comunitário dos oprimidos de uma nação".

A partir da investigação sobre a identidade do EP, realizada por meio de entrevistas semiestruturadas com seus e suas extensionistas, foi possível desvelar como os sujeitos com quem o EP atua ocupam a centralidade de seu agir no/com o mundo. Duas questões previstas no roteiro de perguntas utilizado nas entrevistas (ANEXO B) contribuíram para essa compreensão "O que é o Escritório Popular?" e "Quem são os principais sujeitos com que o EP atua?".

É interessante destacar que, embora houvesse a previsão de uma pergunta específica sobre os sujeitos com quem o EP atua ao final da primeira parte do roteiro (ANEXO B - questão 8), as e os entrevistados trouxeram essa questão já no início das entrevistas (ANEXO B - questão 3). Dessa forma, a partir de nosso referencial freireano, a questão sobre os sujeitos com quem o EP atua revelou-se como tema gerador $^{70}$ para esta pesquisa, na medida em que perpassou as falas dos sujeitos entrevistados no decorrer de suas análises e descrições sobre os elementos caracterizadores do EP - de seu surgimento a seu desenho e quefazer.

\footnotetext{
${ }^{70}$ Estes temas se chamam geradores porque, qualquer que seja a natureza de sua compreensão, como a ação por eles provocada, contêm em si a possibilidade de desdobrar-se em outros tantos temas que, por sua vez, provocam novas tarefas que devem ser cumpridas (FREIRE, 2012, nota de rodapé 68, p.206).
} 
Utilizando o software de apoio à organização de dados qualitativos denominado QDA-Miner (Qualitative Data Analysis Software), construímos categorias referentes aos sujeitos com quem o EP atua e aos critérios para caracterizá-los, a partir da totalidade das falas das pessoas entrevistadas. Ressaltamos que a utilização do software foi unicamente para uma melhor visualização dos dados e que as categorias aqui elaboradas resultam do nosso trabalho de investigação e sistematização, de modo que o software não substituiu o papel da pesquisadora (Hernandez, 2008) ${ }^{71}$.

Sistematizamos os resultados na seguinte figura:
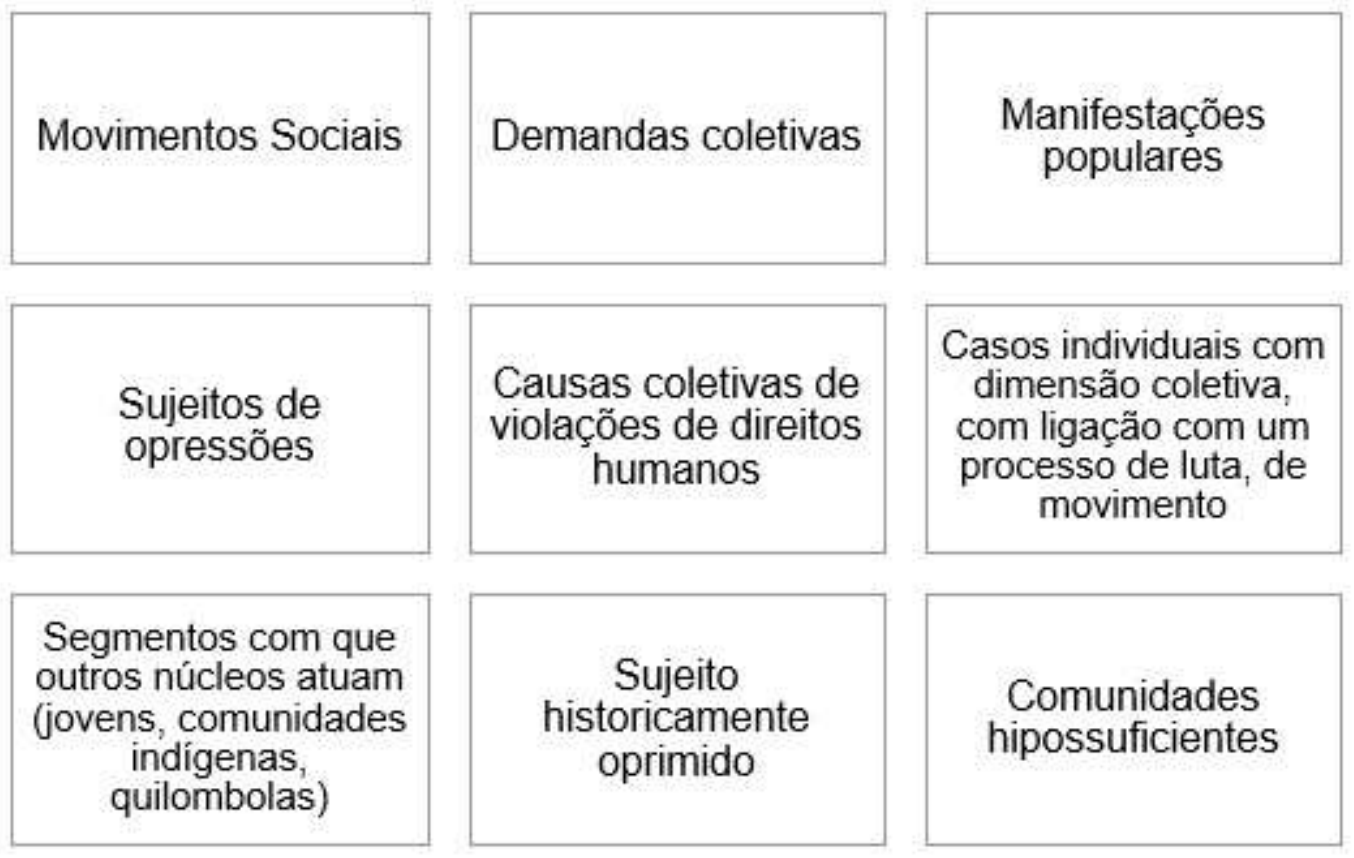

População mais vulnerável, que está mais violentada no cotidiano

Figura 7: Categorização analítica dos sujeitos e critérios caracterizadores da atuação do EP. Fonte: elaboração da autora a partir dos dados coletados na pesquisa empírica.

\footnotetext{
71 Importante destacar que há softwares que randomizam palavras e criam categorias por si próprios, como é o caso do Alceste, um dos principais e mais conhecidos no Brasil para análise qualitativa. Nossa escolha pela utilização do QDA-Miner veio a partir de nossas experiências extensionistas no OBIJUV - grupo de pesquisa e extensão vinculado ao departamento de Psicologia da UFRN, e deveu-se, principalmente porque o trabalho desse software não substitui o da pesquisadora. Ele não cria categorias sozinho, mas exclusivamente contribui para a organização das informações do campo. Dessa forma, nós criamos as categorias e usamos o QDA apenas para auxiliar na sistematização das falas das entrevistas. Conferir: Hernandez (2008).
} 
$\mathrm{Na}$ etapa de campo, percebemos algumas respostas comuns, reveladoras de concepções do projeto. É emblemática a fala de uma das entrevistas, ao sintetizar que "[...] assim surgiu o Escritório Popular: um chamado dos movimentos sociais" (E2, grifo nosso) e, complementando, "O Escritório Popular se transformou numa causa de assessoria jurídica, de advocacia popular para os movimentos." (E2).

Essa noção de "movimentos sociais" que perpassa a caracterização dos "sujeitos" com quem o EP atua, foi sendo ampliada e aprofundada com o desenvolvimento das entrevistas, como é possível identificar no seguinte trecho:

\begin{abstract}
Eu acho que a primeira característica são (sic) sujeitos de opressões. A principal característica: são sujeitos de opressões. Por isso que na outra pergunta, na primeira de todas, eu falei 'causas coletivas e movimentos sociais', mas depois eu falei 'causas coletivas de violação'. Então, com violação de direito, né? E direitos que... como é que eu digo? Um pouco de rol temático: direito à moradia, direito à terra, direito à manifestação. Eu acho que esses foram os três principais que a gente trabalhou esse tempo todo. Então, sempre nesse pólo, como você bem observou, o sujeito da opressão, nesse caso. Enfim, movimento social, eu estou subentendendo não é o movimento social aqui de Petrópolis ${ }^{72}$ pelo estacionamento. [risos]. É o movimento social que costuma ser sujeito de opressão, também, que tão na luta e enfrentam percalços, entraves jurídicos, e que a gente pode, de alguma maneira, desatar ou tentar desatar para que eles prossigam nessa luta. (E3, grifos nossos)
\end{abstract}

De "movimento social", passamos, então, a identificar os "sujeitos de opressão" e a existência de uma "dimensão coletiva" como pressupostos para caracterizar o "quefazer" do EP:

Eu acho que é para além de movimento social porque, por exemplo: a
meu ver a mobilização de junho de 2013 , a "Revolta do Busão" não era
movimento social, não tinha o elemento orgânico que congregasse todo
mundo num movimento. Eu acho que o principal sujeito do Escritório são os
movimentos sociais, não é à toa que a maioria das demandas que a gente
pega é do MST. Mas, por exemplo: junho de 2013 , as "Revoltas do Busão"
daqui, não foram movimentos sociais; a própria atuação do Escritório junto
ao embate com relação à revista vexatória, apesar de que eu não sei se
judicializou, mas assim, ter se mobilizado pra fazer isso já me diz que não é
movimento social porque não houve um movimento social orgânico que
chegou e pediu "faça isso", foi mais uma demanda do Núcleo Penitenciário
que estava em contato com a realidade do sistema prisional e a própria
galera que estava lá, a comunidade do sistema prisional. Então acabou
demandando como violação de direito e pedindo para que isso fosse
parado, e aí a gente acabou pegando isso como demanda. Então acho que
tem sim movimentos sociais, mas também tem uma dimensão aí de
sujeitos oprimidos que estão em situação de violação de direitos
humanos, mas também não todo mundo. Agora, o que é esse "não todo

72 "Petrópolis" é um bairro urbano de classe média-alta de Natal/RN. O conflito referido diz respeito à proposta da Câmara de Dirigentes Lojistas para a criação de um sistema rotativo de vagas para estacionamento na área, com previsão de pagamento por tempo de uso, como estratégia para superar o problema do excesso de veículos e irregularidades no tráfego e estacionamento no bairro. 
mundo" é que eu não sei lhe dizer. Por exemplo, eu não sei qual o elemento que relaciona movimentos sociais de terra com relação ao pessoal do sistema prisional, apesar de que claro: oprimido, que está em situação de direito, mas então por que não... [...] eu acho que precisaria ser um grupo oprimido. [...] existe aí um sujeito historicamente oprimido que são os sujeitos que estão sem-terra, não a galera que está com terra, que está numa violação.... Para mim não é violação é .... Que está sofrendo.... Que entrou com uma ação contra o MST, não é um sujeito historicamente oprimido, ele tem terra, não está fazendo uso da propriedade. O MST vá lá ocupar a propriedade, geralmente às margens do 'rolé', então até se fosse isso, nem a propriedade está sendo violada, mas o elemento que constitui aí eu acho que é se é oprimido ou não, apesar de que não é só isso. Porque, por exemplo, a gente não pega aqui casos de ciganos..., mas se tivesse essa demanda eu acho que a gente acabaria pegando... Só o elemento de 'ser oprimido' eu não acho que é a demanda que a gente pega, acho que tem que ter um caráter um pouco coletivo. Porque, por exemplo, o caso de "Cícero" foi exceção, a gente não pega casos como esse. E quer queira quer não o "bicho" está num polo de opressão ali, ele é um cara oprimido pelo sistema capitalista e tal, mas a gente não dá essa assessoria em casos individuais que não tenham uma dimensão coletiva ali. A gente pega outros casos individuais - como eu falei: os criminais - mas tem uma dimensão coletiva ali. (E6, grifos nossos)

E ainda:

[...] são esses dois elementos principais: movimentos sociais e demanda coletiva. Às vezes é uma demanda coletiva que não necessariamente tá ligada a um movimento social. Mas se a gente entende que tem uma dimensão coletiva, a gente pode entender como importante pegar. Não existe uma coisa pré-estabelecida de quais demandas pega, quais demandas não pega. Geralmente, o que chega a gente discute e vê no caso se vai pegar ou se vai fazer alguma articulação para dar vazão. Eu falei que a gente não pega casos individuais, mas na verdade pega. Existe um acordo, que assim, casos individuais emblemáticos, a gente pega; de violação de direitos humanos, a gente pega. Por exemplo, o caso lá do menino que foi acusado de queimar os ônibus no protesto. Ele foi preso, foi torturado e a gente entendeu que esse era um caso emblemático e fez a defesa criminal dele. $O$ caso da professora Sandra também, que foi acusada de "incitação ao crime". (E7, grifo nosso).

Me parece que a população mais vulnerável, a população que tem, que tá mais violentada no cotidiano, digamos assim. No entanto, na questão da copa eram pessoas que não necessariamente eram de baixa renda, tinham uma renda satisfatória, digamos assim, do ponto de vista da média nacional. Não ficavam na linha de pobreza necessariamente, nem de miserabilidade, nem tampouco eram pessoas que estavam engajadas nos Movimentos Sociais. Então assim, embora o foco principal sejam os Movimentos Sociais e a população mais carente, de baixa renda, mas não tem uma coisa tão fixa e rígida com relação a isso. Me parece que o público alvo, como você coloca entre aspas, é onde tiver opressão, o Escritório pode atuar. Onde houver uma opressão de pessoas, pessoas que estejam sendo subjugadas, e onde houver ilegalidades, a própria classe trabalhadora também. Então me parece que não há uma rigidez tão..., mas o foco, certamente, sim é os Movimentos Sociais e população de baixa renda. (E8, grifos nossos). 
A dimensão coletiva surgiu em todas as falas como pressuposto que caracteriza os casos em que o EP atua. Apesar disso, foi realizada a reflexão de que o projeto não deixou de atuar em situações que, embora sejam procedimentalmente tratadas pelo sistema de justiça formal como sendo de natureza "individual", foram assessoradas pelo EP por terem sido identificadas como essencialmente coletivas, quando observados os interesses e a agenda política envolvidos no conflito. Isso porque esses casos individuais são reveladores de processos mais amplos de criminalização e, portanto, de bloqueio de lutas políticas. Nesse sentido, o EP atua com "questões de violação coletiva e assessoria a movimentos sociais criminalizados" (E3).

Nas entrevistas, foram citados como exemplos de atuação do EP em casos pretensamente individuais o assessoramento jurídico a sujeitos criminalizados por sua atuação em movimentos sociais e/ou em manifestações populares.

Também tinha alguns outros [casos] individuais que o Escritório acabou pegando, mas era muito [caso] criminal dos movimentos da "Revolta do Busão". E aí quando, por exemplo, [o da] professora Sandra - que acabou sendo presa e que a gente acabou pegando - tinha uma dimensão individual, claro, era criminal, mas justamente [tinha] uma dimensão coletiva ali, porque ela não foi presa ali à toa [...], não foi algo sem ligação com um processo de luta, de movimento. (E6 grifo nosso).

A gente pegou pouquíssimos casos individuais. Acho que a gente só pegou casos individuais de criminalização, de pós-manifestação e o único que a gente pegou acho que fora disso foi da filha de Cícero, que morreu no hospital. Mas aí por questões até de vínculo, né? Com o "Leningrado" e tudo. Questões de violação coletiva e assessoria a movimentos sociais criminalizados. Acho que seria isso. (E3, grifo nosso)

O "quefazer" do EP é perpassado, portanto, de "[...] sujeitos, violações de direitos humanos, viés político, ação coletiva, tudo isto caracteriza o trabalho do Escritório Popular", conforme conclui E5:

Coletivas que sejam de violações de direitos humanos no sistema penitenciário, direito à moradia, acesso à terra, enfim, saúde, educação, eu acho que são esses dois fatores que caracterizam bem a atuação do Escritório Popular, e que também tem o viés político, né? E que de repente também seja simbólico, porque eu lembro que chegou um caso, e que também é... seja... eu acho que quando a gente fala de violação de direitos humanos, a gente ta falando muito de... Ta direcionado para um determinado grupo de indivíduos, né? Que seriam os oprimidos. Então assim, eu lembro que chegou um caso, eu acho que na verdade foi pro $\mathrm{CRDH}$, mas como naquela época se misturava muito, que era uma caso de uma associação de moradores que tavam com problema lá, não me lembro do que era, era uma questão de associação de bairro, mas era bairro de classe média, né, Candelária, e tal. E ai tipo, para gente é muito evidente que a gente não vai pegar essa demanda, né? Porque, tipo 
assim, a gente tá... Tem questões... É uma escolha política, pelos sujeitos com quem a gente tá atuando, então, eu acho que eu diria os sujeitos, né? Mesmo que ainda seja uma demanda individual, mas quem são esses sujeitos? São manifestantes? São membros de Movimentos Sociais? São... Enfim... É uma comunidade? Tipo, Mãe Luiza, né? Teve o problema do saneamento, Mãe Luiza, já três contratos que não termina o saneamento e a galera tendo vários problemas e ai tipo, são esses sujeitos, né? São os sujeitos do Leningrado, Mãe Luiza, são sujeitos dos assentamentos, então não é, sujeitos do bairro de Candelária ou sei lá do bairros de Petrópolis. Então, sujeitos, violações de direitos humanos, viés político, ação coletiva, tudo isto caracteriza o trabalho do Escritório Popular. (E5, grifos nossos).

Quando indagadas sobre a questão dos sujeitos com os quais o EP atua, a reação inicial da maioria das pessoas entrevistadas era a constatação de que essa questão nunca foi objeto de deliberação e formulação explícita por parte das e dos integrantes do EP73. Na sequência, as entrevistadas afirmavam a convicção de que, apesar de não ter havido uma discussão interna específica sobre essa questão, havia uma espécie de "acordo tácito" (E1) entre as e os integrantes do EP, um tipo de "compreensão tácita" (E1), "que é uma questão de sentir" (E1) e "que as pessoas [do EP] têm esse sentimento comum" (E1), que "é difícil mesmo. É meio que... A gente sente na hora, mas não sabe explicar por quê" (E3).

Eu acho que há uma espécie de consenso tácito, uma vez que há essa
convergência político-ideológica entre as pessoas que participam do Núcleo
[EP] [...] No caso uma compreensão tácita. [...] Por exemplo, as questões
envolvendo ações possessórias envolvendo o MST, por exemplo. Questões
envolvendo "Mãe Luíza", que já vem do "Núcleo Urbano" [...]. Questões
envolvendo movimentos sociais de modo geral, como o de Welington, o
MLB. Questões envolvendo manifestações populares, por exemplo. Eu
acho que dentro dessa compreensão tácita, dessa compreensão, eu
compararia até um pouco com a common law, né... que é uma questão de
sentir, eu acho, que as pessoas têm esse sentimento comum. Tão
partindo desse sentimento comum de que aquela demanda
espiritualmente corresponde à perspectiva do projeto. [...] Direitos
Humanos de uma forma geral, né? (E1, grifos nossos).

Destacamos, em especial, que a referida "compreensão tácita" foi, de fato, apresentada nas falas de todas as entrevistadas, na medida em que houve uma convergência de compreensões no conteúdo das respostas, corroborando a reação inicial. Além de elencar nominalmente diversos dos sujeitos com quem o EP já havia atuado, as entrevistadas foram além, desvelando um "compromisso ético" (E4) de quem integra o EP para com um projeto de transformação da realidade:

73 Referente ao espaço para formações e debates internos do EP, verificamos nas entrevistas a compreensão de que certas reflexões são pressupostas, visto ser critério para ingresso no projeto a passagem por outros Núcleos do Motyrum. Abordaremos essa questão posteriormente. 
[...] é um recorte de alguns sujeitos sociais... e aí isso daí é uma questão de ideologia ${ }^{74}$ dos integrantes do projeto também [...] isso é mais um compromisso ético, acho, existencial mesmo, de como você se põe no mundo, a favor do quê, né? E nesse sentido, as pessoas que integravam o projeto, que integram, têm uma concepção que o conhecimento deveria ser a favor da transformação da realidade e do dia-a-dia das pessoas. (E4)

"Acordo tácito", "compromisso ético" e "transformação da realidade" são, portanto, elementos presentes nas falas das pessoas entrevistadas e que revelam uma dimensão ideológica marcante da identidade do EP, correspondente a "[...] uma questão política de aliança com movimentos sociais" (E2) que é pressuposta para a práxis extensionista com os referidos sujeitos. O "quefazer" do EP é caracterizado, portanto, como engajado com um projeto de emancipação social que pressupõe a transformação da realidade de opressão desses mesmos sujeitos.

Realizando uma análise a partir do pensamento freireano, compreendemos que esse "compromisso ético" com a transformação da realidade, que também apareceu indicado nas entrevistas por termos tais como "aliança", "pacto" e "ligação", é assumido pelas e pelos extensionistas a partir de uma leitura do mundo em diálogo com esses sujeitos e visando a sua emancipação (FREIRE, 2012).

No contexto de formulação do EP, originado em um curso de graduação em direito numa universidade pública federal ${ }^{75}$, essa perspectiva de atuação é

${ }^{74}$ Remetemos à leitura de duas obras que se propõem a refletir teoricamente sobre "ideologia": "O que é ideologia", de Marilena Chauí (1986); e "O poder da ideologia", de István Mészáros (2004). Partindo da noção que compreende a história como práxis, Chauí apresenda um conceito de ideologia que corresponde a um movimento de "ocultamento da realidade social" (1986 p.21). A autora explica que "[...] a história é o real e o rela é o movimento incessante pelo qual os homens, em condições que nem sempre foram escolhidas por eles, instauram um modo de sociabilidade e procuram fixa-lo em instituições determinadas [...] Além de procurar fixar seu modeo de sociabilidade através de instituições determinadas, os homens produzem ideias ou representações pelas quais procuram explicar e compreender sua própria vida individual, social, suas relações com a natureza e com o sobrenatural. Essas ideias ou representações, no entanto, tenderão a esconder dos homens o modo real como suas relações sociais foram produzidas e a origem das formas sociais de exploração econômica e de dominação política. Esse ocultamento da realidade social chama-se ideologia. Por seu intermédio, os homens legitimam as condições sociais de exploração e de dominação, fazendo com que pareçam verdadeiras e justas. [...]". (CHAUÍ, 1986, p.20 e 21). Mészáros, por sua vez, problematiza a ideologia na interpretação das relações sociais e a identifica como "[...] uma forma específica de consciência social, materialmente ancorada e sustentada." (2004, p.65).

${ }^{75}$ Ao tratarmos de contextos universitários, é relevante levar em consideração o fenômeno da elitização do ensino superior e dos cursos de graduação em direito no Brasil. A criação e a estruturação dos cursos de direito no país foram tardias (após 1808) e estiveram atreladas à lógica colonial que marcou o processo de organização social brasileira. Nesse sentido, a formação profissional sempre esteve presente no horizonte universitário desde a fundação das primeiras faculdades de direito do Brasil. Ao analisarmos a história socioeconômica do país, notamos tentativas reformistas universitárias, tais como as realizadas no período da Ditadura Empresarial-Civil-Militar (com destaque para a Lei n. 5.540, de 1968, que implementou uma reforma universitária), que acabaram reforçando o sentido técnico da formação profissional em detrimento de uma tradição genuinamente universitária. $\mathrm{O}$ ensino superior foi e ainda é ajustado às determinantes do 
emblemática, pois, contribui para o rompimento de uma "cultura do silêncio" (LIMA, 2011; FREIRE, 2012) em relação àqueles sujeitos que estão submetidos à "negação do seu ser como gente" (FREIRE, 2012; HIDAKA, 2012) e ao bloqueio de seu processo permanente de "busca por ser mais" (FREIRE, 2012, 33). Isso, potencialmente, modificaria a "concepção de mundo" das e dos estudantes do projeto, moldando o seu "agir no/com o mundo".

\begin{abstract}
O Escritório Popular, eu acho que... Primeiro: é um projeto de disputa dentro do curso de direito... A princípio, né? Você discute uma concepção de direito que está ali, uma concepção de direitos humanos e de certa forma acaba formando profissionais de direito que tenham uma maior proximidade a movimentos sociais, então pra um curso que tem um perfil muito de classe média, muito de gente que saiu de escolas particulares - agora que mudou mais o perfil, mas, pelo menos na minha época era assim - tem um papel muito importante, de você colocar... De você aproximar estudantes a movimentos sociais e começar a modificar a concepção de mundo que essa pessoa, que esse povo [estudantes] tem, né? Que os estudantes têm. Mas ele também, o Escritório Popular também tem.... Para os estudantes, tem esse papel e é importantíssimo porque você consegue levar esse... Sair da sala de aula para ter uma compreensão mais do real, mais do que acontece de fato na sociedade. [...] (E6, grifos nossos).
\end{abstract}

Quando trouxemos dados sobre os conflitos no campo para caracterizar a criação da RENAP e historicizar o surgimento do EP, verificamos a permanência, no tempo, do processo de desgenteficação e desumanização, fenômenos decorrentes de uma estrutura opressora que perpassa a formação da sociedade brasileira e latinoamericana (FREIRE, 2012).

Nesse processo de desgenteficação, importa identificar no contexto de ação do EP os sujeitos que tem a sua humanidade negada e, ao mesmo tempo, estão em luta por sua restauração, os "[...] 'condenados da terra'76, dos oprimidos, dos esfarrapados

capitalismo internacional, condizendo com os interesses das elites e afastada de um engajamento com a transformação social do Brasil. A formação técnica que é voltada à manutenção dos interesses estabelecidos pela ordem econômica mundial, tem na racionalização e na eficiência dois de seus principais discursos valorativos e orientadores. Marca, acentuadamente, a formação bacharelesca de profissionais nas áreas da engenharia, da medicina e do direito. Nesse sentido, o ensino jurídico pode ser compreendido como lócus de formação burocrática para o Estado e o Capital. A elitização não é, no entanto, um fenômeno isolado dos cursos de direito. Trata-se, na verdade, de um fenômeno generalizado nas diferentes áreas do conhecimento e que é agravada em contextos de desigualdades sociais, tais como a realidade brasileira (Cf.: GENTILI, 1995; TRINDADE, 2003). Dados do Censo do Ensino Superior (CES), do Instituto Brasileiro de Geografia e Estatísticas (IBGE), tomando como referência o ano de 2014, revelam que, embora o número de estudantes no ensino superior tenha aumentado, a maioria ainda é branca e provém das classes média e alta. É necessário ressaltar, no entanto, que ações afirmativas e outras políticas públicas voltadas para o ensino superior foram desenvolvidas no período de 2003 a 2015 no sentido de mitigar o profundo processo de elitização dessa categoria de ensino. São exemplos: as políticas de cotas raciais e socioeconômicas, as turmas especiais do PRONERA, os impactos do REUNI.

${ }^{76}$ Paulo Freire utiliza a expressão "condenados da terra" entre aspas, possivelmente em referência à categoria desenvolvida por Frantz Fanon, cuja expressão maior é a obra que leva o mesmo nome: "Os 
do mundo [...]' (FREIRE, 2012, p.35): “[...] dos 'sem-terra', dos 'sem-escola', dos 'semcasa', dos favelados; na luta contra a discriminação racial, contra a discriminação de classe, de sexo." (FREIRE, 2000, p.75).

Essas desigualdades que perpassam a "estrutura opressora" contrapõem grupos em polos opostos, antagônicos. Estabelecem-se como relações do tipo opressor/ oprimido ou ainda violadores/violados, ser/não ser gente, que são identificados por Freire como forjados a partir do processo de colonização europeia da América e que permanecem inalterados ainda no século $\mathrm{XXI}^{77}$ :

\begin{abstract}
Nesse sentido o estudo do passado traz à memória de nosso corpo consciente a razão de ser de muitos dos procedimentos do presente e nos pode ajudar, a partir da compreensão do passado, a superar marcas suas. A compreender, no caso, por exemplo, do passado da conquista como, sem dúvida, ela se repete hoje, de forma diferente, ás vezes. É exatamente porque o passado se faz presente, seja o passado do conquistador, seja o do conquistado, que os quilombos, momento exemplar da luta dos conquistados, se repetem hoje nas lutas populares no chão da América. (FREIRE, 2000, p.75)..$^{78}$
\end{abstract}

Nessa mesma linha, Enrique Dussel também remete ${ }^{79}$ ao período de colonização na América como um marco fundante dessa estrutura opressora. Em sua obra "Hacia una filosofia política crítica", formula o conceito de "sem-direitos":

condenados da terra", de 1961. Sobre o contato de Paulo Freire com a obra de Fanon, afirma Antônio Sérgio Alfredo Guimaraes: "No exílio chileno desde 1964, foi o pedagogo revolucionário Paulo Freire, também muito influenciado pelo pensamento existencialista católico e pelo nacionalismo anticolonialista do Iseb, quem fez a leitura de Fanon mais absorvedora. Em sua Pedagogia do oprimido, Freire foi, talvez, o primeiro brasileiro a abraçar as idéias de Fanon. Pelas indicações do próprio Freire, ele tomou conhecimento do revolucionário martinicano entre 1965 e 1968. É o que ele insinua em duas passagens de Pedagogia da esperança". (GUIMARAES, 2008, online).

77 Conferir: WALSH (2007 e 2008), QUIJANO (2005a e 2005b), MIGNOLO (2007 e 2010) e SEGATO (1998 e 2007).

78 Não serão, pois, os 500 anos que nos separam da chegada invasora que me farão bendizer a mutilação do corpo e da alma da América e cujas mazelas carregamos hoje ainda. O corpo e a alma da América, o corpo e a alma de seus povos originários, assim como o corpo e a alma dos homens e das mulheres que nasceram no chão americano, filhos e filhas de não importa de que combinações étnicas, o corpo e a alma de mulheres e homens que dizem não à dominação de um Estado sobre o outro, de um sexo sobre 0 outro, de uma classe social sobre a outra, sabem, o corpo e a alma dos progressistas e das progressistas, o que representou o processo de expansão europeia que trazia em si as limitações que nos eram impostas. E porque sabem não podem bem-dizer os invasores nem a invasão. Por isso mesmo é que a melhor maneira, não de festejar os 500 anos de invasão, não cruzando, porém, os braços diante dos festejos a eles feitos, seria homenagear a coragem, a rebeldia, a decisão de brigar, a bravura, a capacidade de lutar contra o invasor; a paixão pela liberdade, de índios e índias, de negros e negras, de brancos e brancas, de mamelucos, que tiveram seus corpos rasgados, seus sonhos despedaçados, suas vidas roubadas. Seus gestos de rebeldia se repetem hoje na luta dos "sem-terra", dos "sem-escola", dos "sem-casa", dos favelados; na luta contra a discriminação racial, contra a discriminação de classe, de sexo. (FREIRE, 2000, p.74).

${ }^{79}$ Sobre a colonização da América Latina, conferir: DUSSEL,1993. 
São as gerações futuras face aos crimes antiecológicos das gerações presentes; é o caso da mulher na sociedade machista, das raças não brancas na sociedade racista ocidental, dos homossexuais nas estruturas heterossexuais, dos marginais, das classes exploradas por uma economia do lucro, dos países pobres e periféricos, dos imigrantes, e também dos Estados nacionais debilitados pela estratégia do capital global nas mãos de corporações transnacionais [...] As vítimas de um 'sistema do direito vigente' são os 'sem-direito' (ou os que não têm, todavia, direitos institucionalizados, reconhecidos, vigentes). Trata-se, então, da dialética de uma comunidade política com 'estado de direito' ante muitos grupos emergentes sem-direitos, vítimas de sistemas econômico, cultural, militar, etc., vigentes. (DUSSEL, 2001, p. 151, tradução livre da autora).

A identificação da estrutura opressora como tal não ocorre a priori. O seu reconhecimento dá-se por meio da conscientização ${ }^{80}$ resultante de um processo educativo de aproximação crítica da realidade (FREIRE, 2001, p.30). Seguindo o pensamento freireano e considerando sua concepção de educação como prática da liberdade, uma vez desvelada a estrutura opressora que permeia as diversas dimensões da vida humana, a conscientização passa a ser o ponto de partida - e não um objetivo final - para provocar ação transformadora da realidade, cujo fim é o processo de libertação dos homens e mulheres, enquanto superação dessa estrutura. Assim, trata-se da conscientização acerca dessa matriz de hierarquização de grupos humanos como o (primeiro) passo gerador de um agir no mundo para a transformação da realidade, tendo em vista a libertação humana.

Analisando a Figura 6 com a sistematização sobre os sujeitos com que o EP atua a partir das falas das e dos extensionistas entrevistados e o levantamento de casos do projeto que realizamos, verificamos que a dimensão coletiva se destaca como um dos elementos centrais para caracterizar a ação do EP e os sujeitos com quem escolhe atuar. Em seguida, observamos dois outros elementos que merecem nossa atenção nessa caracterização: as categorias movimentos sociais e sujeitos historicamente oprimidos. Assim, passaremos a uma breve análise dessas categorias, uma vez que a tentativa de concatenar as ideias e formulações teóricas que as perpassam a partir da ação concreta do EP nos auxiliará a chegar a uma

80 Esta tomada de consciência não é ainda a conscientização, porque esta consiste no desenvolvimento crítico da tomada de consciência. A conscientização implica, pois, que ultrapassemos a esfera espontânea de apreensão da realidade, para chegarmos a uma esfera crítica na qual a realidade se dá como objeto cognoscível e na qual o homem assume uma posição epistemológica. A conscientização é, neste sentido, um teste de realidade. Quanto mais conscientização, mais se "desvela" a realidade, mais se penetra na essência fenomênica do objeto, frente ao qual nos encontramos para analisá-lo. Por esta mesma razão, a conscientização não consiste em "estar frente à realidade" assumindo uma posição falsamente intelectual. A conscientização não pode existir fora da "práxis", ou melhor, sem o ato ação - reflexão. Esta unidade dialética constitui, de maneira permanente, o modo de ser ou de transformar o mundo que caracteriza os homens [e as mulheres]. (FREIRE, 2001, p.30) 
compreensão sobre esses sujeitos com quem o projeto atua e ao papel que desempenham nas suas demais concepções.

Nesse sentido, recorremos inicialmente a Franz Hinkelammert e sua contribuição como expoente do pensamento crítico latino-americano ${ }^{81}$, cuja compreensão é a de que nos encontramos em um "labirinto da modernidade" (HINKELAMMERT, 2007) e que, portanto, é necessário empreender esforços para encontrarmos uma saída:

Ciertamente hay una salida. Si no la tuviera, no sería un laberinto, sino un infierno. Pero no está a la mano. Se ha entrado al laberinto, pero es imposible encontrar la salida. La salida está por dónde se entró. En el caso de la modernidad, la entrada al laberinto ha sido inevitable, porque no se sabía de que se trataba de un laberinto al cual se entró. Las promesas del camino parecían esplendidas, y una vez entrada, la salida se perdió.

O tema dos sujeitos é um tema fundamental no pensamento de Hinkelammert (SUNG, 2014, p.11). O economista e teólogo formula a compreensão de que o ser humano como sujeito é uma determinação que surge com a modernidade e com a formulação de Descartes que concebe o sujeito a partir da relação sujeito-objeto (HINKELAMMERT, 2007, p.171). É um "sujeito do pensamento, enfrentando o mundo dos objetos" ${ }^{82}$, é o "indivíduo possuidor", em que a "relação sujeito-objeto é a relação na qual o indivíduo se dirige ao mundo para dominar e possuir" (HINKELAMMERT, 2007, p.171):

\footnotetext{
Este sujeto del cogito ergo sum es un sujeto trascendental, que desde un punto de vista fuera de la realidad corporal del mundo juzga sobre este mundo como mundo objetivo, del cual no es parte, sino juez. Por tanto, no puede tener existencia corporal.
}

Segundo Hinkelammert, essa ideia de sujeito integra um modelo de "sociedade de mercado" autodestrutivo, que transforma, inclusive, o próprio sujeito em objeto e alimenta uma racionalidade que coloca elementos tais como a eficiência e a competitividade como sendo os critérios máximos do atual sistema e transformando-se em uma grande engrenagem em que "tudo é insumo para um produto e o produto tem que crescer com taxas máximas" (HINKELAMMERT, 2007, p.173-174). Para o economista, as crises desse modelo são óbvias e evidenciam-se, por exemplo, na "exclusão cada vez maior de partes da população, das crises das

\footnotetext{
${ }^{81}$ Hinkelammert foi o primeiro ganhador do "Prêmio Libertador ao Pensamento Crítico", criado pelo governo da Venezuela em 2005 e no qual concorreu com 136 (cento e trinta e seis) obras de 16 (dezesseis) países.

82 Tradução livre.
} 
relações sociais, das crises do meio ambiente" (HINKELAMMERT, 2007, p.175). Assim, a ordem desenvolve tendências até sua própria destruição e se faz autodestrutiva (HINKELAMMERT, 2007, p.175).

Nesse mesmo sentido, Paulo Freire formula a ideia de "corpo consciente" como "consciência intencionada ao mundo, à realidade" (FREIRE, 1975, p.66), como expressão da relação dialética entre os condicionamentos históricos colocados a homens e mulheres e sua liberdade (FREIRE, 2012, p.98). Freire reafirma a "existência histórica" (FREIRE, 2012, p.97) de homens e mulheres, criticando a perspectiva de relação em que há sujeitos objetificados (oprimidos) por indivíduos possuidores (opressores). A nosso ver, estabelece com sua formulação de "corpo consciente" um diálogo com a concepção de sujeito de Hinkelammert e se contrapõe à concepção cartesiana em suas análises sobre a formação da estrutura opressora de nossa sociedade.

Partindo desse mesmo olhar crítico à concepção cartesiana de sujeito, Hinkelammert desenvolveu a ideia de sujeito não como um a priori, mas como um a posteriori de um processo (HINKELAMMERT, 2007, p.179). Processo esse que se revela como reação, como resistência, à essa destrutividade da sociedade de mercado, a cuja racionalidade chama de "irracionalidade do racionalizado" (HINKELAMMERT, 2007, p.176); "não se trata de uma reação desde fora do campo dos interesses materiais, mas de dentro. O ser humano como ser natural necessita orientar-se por seus interesses materiais" (HINKELAMMERT, 2007, p.176). Assim, afirma tratar-se do "retorno do sujeito reprimido e esmagado, falamos do ser humano como sujeito dessa racionalidade, que enfrenta a irracionalidade do racionalizado" (HINKELAMMERT, 2007, p.178).

Es un llamado a hacerse sujeto. El ser humano no es sujeto, sino hay un proceso en el cual se revela, que no se puede vivir sin hacerse sujeto. No hay sobrevivencia, porque el proceso, que se desarrolla en función de la inercia del sistema, es autodestructor. Aplasta al sujeto, que cobra conciencia de ser llamado a ser sujeto en cuanto se resiste a esta destructividad. Tiene que oponerse a la inercia del sistema si quiere vivir, y al oponerse, se desarrolla como sujeto. El llamado a ser sujeto se revela en el curso de un proceso. Por eso, el ser sujeto no es un a priori del proceso, sino resulta como su a posteriori.

- En este sentido, el ser humano es parte del sistema en cuanto actor o individuo calculante. En cuanto sujeto está enfrentado al sistema, lo trasciende. Esta respuesta es el bien común. Es propuesta o alternativa, que surge a partir del sujeto. Interpela al sistema, para transformarlo (HINKELAMMERT, 2007, p.179). 
Hinkelammert destaca 0 aparecimento de resistências frente a essa "irracionalidade do racionalizado", defendendo que a recuperação do ser humano como sujeito está nessa perspectiva de libertação forjada e forjadora de uma racionalidade que enfrenta a irracionalidade do racionalizado (HINKELAMMERT, 2007, p.178). Essa racionalidade que resiste à irracionalidade do racionalizado da sociedade de mercado autodestrutiva, rompe com a concepção individualista do sujeito cartesiano (paradigma da modernidade) para afirmar a dimensão coletiva do sujeito que "só em conjunto com os outros pode viver" (HINKELAMMERT, 2007, p.178):

\footnotetext{
Este sujeto tiene un lugar real, al saber, que el respeto del conjunto es condición de su propia vida. No se "sacrifica" por otros, sino descubre, que solamente en el conjunto con los otros puede vivir. Por eso, no sacrifica a los otros tampoco. Es precisamente el individuo calculador, que, al totalizarse el cálculo de los intereses, se sacrifica a sí mismo y a los otros. Por eso el ser humano como sujeto no es una instancia individual. La intersubjetividad es condición para que el ser humano llegue a ser sujeto. Se sabe en una red, que incluye la misma naturaleza externa al ser humano: que viva el otro, es condición de la propia vida (grifo nosso).
}

Nossa análise identifica um diálogo entre essa concepção de sujeito de Hinkelammert e o pensamento de Paulo Freire, na medida em que o educador pernambucano, ao identificar o "oprimido" e justificar a necessidade de uma "pedagogia do oprimido", reafirma também a dimensão coletiva do sujeito para que o processo seja de libertação: "ninguém liberta ninguém, ninguém se liberta sozinho: os homens [e mulheres] se libertam em comunhão" (FREIRE, 2012, p.57).

Da mesma forma, a dimensão da crítica ao sujeito como "indivíduo possuidor" e do sujeito transformado em objeto, assim como em Hinkelammert, também está presente em Freire. A partir da realidade concreta com que teve contato em seu quefazer de educador, Freire compreende a existência histórica da relação oprimido - opressor, em que "os oprimidos se sentem como se fossem uma quase 'coisa' possuída pelo opressor", que "no seu afã de possuir, [...] ser é ter à custa quase sempre dos que não têm [os oprimidos]" (FREIRE, 2012, p.57). Assim, observamos que essa matriz opressora identificada por Freire guarda muita semelhança com os processos que Hinkelammert reconhece como sendo do que chama de sociedade de mercado autodestrutiva.

Um elemento central que perpassa a relação oprimido - opressor e a sociedade de mercado é a destruição da vida humana. Seja na relação de dependência dos oprimidos com os opressores (FREIRE, 2012), seja na concepção 
de sujeito como indivíduo possuidor (HINKELAMMERT, 2007), é notória a coisificação do sujeito e, portanto, sua própria negação enquanto sujeito, um processo destrutivo de vida. Nesse mesmo sentido, Enrique Dussel defende a afirmação da vida como um princípio da Ética da libertação, que ao reconhecer o sistema econômico como produtor de pobreza (morte), reconhece-o como negação de vida humana (DUSSEL, 2001, p.144).

Dussel afirma que "a situação crítica que interessa à Ética (e à Política) da Libertação se coloca quando certos cidadãos são excluídos não-intencionalmente do exercício de novos direitos que o 'sistema de direito' não pode incluir” (DUSSEL, 2001, p.151). Daí desenvolve o conceito dos "sem-direitos" como esses cidadãos excluídos, que têm sua vida negada através do não reconhecimento de seus direitos.

Temos, então, que o "oprimido" de Freire, o sujeito esmagado de Hinkelammert, os "sem-direitos" de Dussel, fazem-se gente a partir da ação coletiva e de processos de conscientização, partindo de uma atitude crítica em relação à ética de mercado, própria da sociedade de mercado autodestrutiva (HINKELAMMERT, 2007), do sistema capitalista que vivencia o neoliberalismo (FREIRE, 2002): "o discurso da globalização que fala da ética esconde, porém, que a sua é a ética do mercado e não a ética universal do ser humano, pela qual devemos lutar bravamente se optamos, na verdade, por um mundo de gente" (grifo nosso) (FREIRE, 2002, p.144).

O "chamado para fazer-se sujeito" (HINKELAMMERT, 2007, p.179) que compreende o sujeito como um a posteriori de processos de resistência e em comunhão com o outro, tem a mesma substância do processo de genteficação de Freire. Resultado da "denúncia" da situação opressora negadora de vida e do "anúncio" de um mundo encharcado de humanidade ("Eu acho que envolvimento [com os sujeitos], ele te encharca de realidade, ele te motiva" - E5, grifo nosso):

\footnotetext{
Não creio que as mulheres e os homens do mundo, independentemente até de suas opções políticas, mas sabendo-se e assumindo-se como mulheres e homens, como gente, não aprofundem o que hoje já existe como uma espécie de mal-estar que se generaliza em face da maldade neoliberal. Malestar que terminará por consolidar-se numa rebeldia nova em que a palavra crítica, o discurso humanista, o compromisso solidário, a denúncia veemente da negação do homem e da mulher e o anúncio de um mundo "gentificado" serão armas de incalculável alcance (FREIRE, 2002, p.144).
}

Retomando os elementos que destacamos a partir da Figura 6, temos na categoria "movimentos sociais" uma das concepções mais citadas nas falas das 
pessoas entrevistadas para caracterizar os sujeitos com quem o EP atua. Essa expressão apresenta uma diversidade de compreensões, mas um dos elementos comuns a todas é sua perspectiva de "dimensão coletiva", outro elemento recorrente nas entrevistas no que diz respeito aos sujeitos. De acordo com Maria da Glória Gohn, referência no campo de estudos e teorias sobre movimentos sociais, "um movimento social é sempre expressão de uma ação coletiva e decorre de uma luta sociopolítica, econômica ou cultural” (GOHN, 2014, p.14).

Ao traçar o histórico do uso do termo "movimento social", a socióloga aponta que desde as primeiras vezes em que foi usado (em meados do século $\mathrm{XIX}^{83}$ ) até a primeira metade do século $X X$, a expressão esteve frequentemente associada às ideias de "distúrbios populares" (GOHN, 2014, p.20), "problemas sociais", "fator de disrupção da ordem" (GOHN, 2014, p.22). No âmbito dos estudos clássicos norteamericanos sobre as ações coletivas, a professora destaca que a ênfase na abordagem sociopsicológica foi o grande ponto de destaque, mencionando que "a grande questão era a inadaptação deles [os indivíduos] àquelas estruturas [as macroestruturas sociais], o que gerava desajustes e conflitos" (GOHN, 2014, p.23). Nos anos de 1950 e parte da década de 1960, Gohn ressalta que os estudos de ciências sociais começavam a atribuir um significado atrelado a mudanças sociais:

[...] abordavam os movimentos no contexto das mudanças sociais, e os viam como fontes de conflitos e tensões, fomentadores de revoluções, revoltas e atos considerados anômalos no contexto dos comportamentos coletivos vigentes. [...] Movimentos sociais e revoluções eram termos utilizados muitas vezes como sinônimos, e sempre que se falava em movimento a categoria "trabalhador" era destacada. (GOHN, 2014, P.24).

Mas é a partir dos anos 1970 que, para Gohn, "a produção teórica na sociologia [...] nos revela novos olhares sobre as ações coletivas" (GOHN, 2014, p.25), com destaque para os movimentos sociais como atores importantes e culminando com a incorporação da temática dos movimentos sociais na bibliografia geral sociopolítica nos anos de 1980.

É importante pontuarmos, quanto à construção das abordagens teóricas sobre os movimentos sociais, que tendo em vista as correntes teóricas identificadas por Gohn a esse respeito (histórico-estrutural, culturalista-identitária e institucional/organizacional-

\footnotetext{
83 "Lorenz von Stein foi um dos pioneiros a utilizar o termo 'movimento social', em 1842" (GOHN, 2014, p.20), mas Gohn registra que Blumer "foi o primeiro a utilizar o termo movimento social na produção teórica", em 1939 (GOHN, 2014, p.22).
} 
comportamentalista ${ }^{84}$ ) nos encontramos mais próximas da primeira. Isso porque suas referências marxistas ou que tomam essa abordagem como inspiração, partindo de análises objetivas da realidade social, enxerga nesses sujeitos (os movimentos sociais) o protagonismo de processos de transformação social (GOHN, 2014, P.28).

Em que pese à nova onda de movimentos sociais emergente na Europa a partir dos anos de 1960-1970 ter colocado essa categoria na centralidade de diversas investigações (GOHN, 2014, p.31), destacamos as experiências dos movimentos sociais latino-americanos como resistência ao cenário político local e como atores em luta por redemocratização e por direitos. Essas movimentações desde "nossa América" apresentaram para a agenda desse campo de estudos novos sujeitos, tal qual defendeu o sociólogo Eder Sader em seu livro "Quando novos personagens entrarem em cena". $\mathrm{Na}$ obra, Sader parte das análises das experiências populares do cotidiano da década de 1970 no Brasil, que interpreta como "manifestações de um comportamento coletivo de contestação da ordem social vigente" (SADER, 1988, p.30), para defender que temos naquele momento novos atores nascendo no cenário político. Marilena Chauí, ao prefaciar referido livro, explica por que esses sujeitos são considerados "novos":

Por que sujeito novo?

Antes de mais nada, porque criado pelos próprios movimentos sociais populares do período(...). Em segundo lugar, porque se trata de um sujeito coletivo e descentralizado(...). O novo sujeito é social; são os movimentos sociais populares em cujo interior indivíduos, até então dispersos e privatizados, passam a definir-se, a reconhecer-se mutuamente, a decidir e agir em conjunto e a redefinir-se a cada efeito resultante das decisões e atividades realizadas. Em terceiro lugar, porque é um sujeito que, embora coletivo, não se apresenta como portador da universalidade definida a partir de uma organização determinada que operaria como centro(...). Referido à Igreja, ao sindicato e às esquerdas, o novo sujeito neles não encontra o velho centro, pois já não são centros organizadores no sentido clássico e sim 'instituições em crise' que experimentam 'a crise sob forma de um descolamento com seus públicos respectivos'(...). (CHAUÍ, 1988, p.10-11)

O cenário político do Brasil e da América Latina nos anos 1970, e que é analisado por Sader, era de ditadura civil-militar ${ }^{85}$ e, portanto, de violações sistemáticas

${ }^{84}$ Para uma revisão bibliográfica mais ampla e melhor localização na construção da categoria movimentos social, bem como, um panorama amplo de seus teóricos e abordagens, indicamos a obra "Novas Teorias dos Movimentos Sociais", de Maria da Glória Gohn, bem como outras produções da socióloga. Por não ser esse o tema central deste trabalho, optamos por realizar um resgate mais breve e centrado nos aspectos que avaliamos como mais relevantes para os objetivos desta pesquisa, sem deixar de situar de forma mais geral a temática.

85 Nossa compreensão é a de que setores da sociedade civil brasileira integraram a "elite orgânica autoritária" (LENTZ, 2015, p.321) que comandou o período ditatorial no Brasil. Por essa razão, utilizamos a expressão ditadura civil-militar. A esse respeito, recomendamos o artigo de Rodrigo Lentz, intitulado "A participação de setores da sociedade civil na Ditadura Civil-Militar brasileira", que foi publicado no sétimo volume da Série O Direito Achado na Rua (SOUSA JUNIOR et al, 2015, p. 319-324). 
de direitos perpetradas por agentes do Estado, como "restrição à liberdade de expressão, prisões arbitrárias, criminalização dos movimentos sociais, tortura e assassinatos" (FONSECA; RAMPIN, 2015, p.35). Se por um lado a repressão e o cerceamento de direitos eram a tônica da ação do Estado, apoiada pelos setores dominantes da sociedade, a reação dos grupos oprimidos e principais alvos da violência estatal era pautada por resistência e organização populares. Esses "grupos populares os mais diversos que irrompiam na cena pública reivindicando seus direitos, a começar pelo primeiro, pelo direito de reivindicar direitos" (SADER, 1988, p.26) levaram a uma "revalorização de práticas sociais presentes no cotidiano popular" (SADER, 1988, p.26):

\begin{abstract}
Manifestações incapazes de incidir eficazmente sobre a institucionalidade estatal - antes interpretadas como sinal de imaturidade política - começam a ser valorizadas como expressão de resistência, de autonomia e criatividade. [...] É no quadro dessa crise [dos referenciais políticos e analíticos que balizavam as representações sociais sobre o Estado e a sociedade em nosso país] que intelectuais (acadêmicos ou militantes) deixam de ver o Estado como lugar e instrumento privilegiados das mudanças sociais e começam a enfatizar uma polarização - às vezes até maniqueísta - entre sociedade civil e Estado (SADER, 1988, p.33).
\end{abstract}

A análise de Sader dialoga com o resgate histórico feito por Maria da Glória Gohn sobre os movimentos sociais e estudos sobre eles, ao perceber o deslocamento da leitura realizada sobre esses atores: de distúrbios e sinais de imaturidade políticas passam a ser enxergados como agentes de transformação da realidade social. Trata-se da "emergência de novos padrões de práticas coletivas" e igualmente da mudança em relação às representações elaboradas sobre tais práticas e sobre as classes trabalhadoras (SADER, 1988, p.34). Assim, "de onde ninguém esperava, pareciam emergir novos sujeitos coletivos, que criavam seu próprio espaço e requeriam novas categorias para sua inteligibilidade" (SADER, 1988, p.36, grifo nosso).

Preocupado com a representação desses novos sujeitos coletivos perante 0 direito, José Geraldo de Sousa Junior, coordenador do grupo de pesquisa "O Direito Achado na Rua", formulou a categoria de "sujeito coletivo de direito" (SOUSA JUNIOR, 2011, p.167) com um olhar que parte da literatura sociológica. Segundo o jurista, "a emergência do sujeito coletivo pode operar um processo pelo qual a carência social contida na reivindicação dos movimentos é por eles percebida como negação de um direito, o que provoca uma luta para conquista-Io" (SOUSA JUNIOR, 2011, p.171).

Sousa Junior reconhece a importância da ação dos novos movimentos sociais para o processo de redemocratização ocorrido, nas últimas décadas, na 
América Latina ${ }^{86}$. A partir da produção teórica sobre os movimentos sociais no campo das ciências sociais propõe que seja pensado em "um novo sujeito coletivo que se emancipe enquanto sujeito coletivo de direito, em um novo modo de produção do social, do político e do jurídico" (SOUSA JUNIOR, 2011, p.174). Nesse sentido, as referências supracitadas de Eder Sader e Marilena Chauí foram essenciais no que diz respeito à fundamentação filosófica que "permite sustentar o sentido projetivo dessa nova identidade social para indicar o seu potencial protagonismo de sujeito instituinte de direitos" (SOUSA JUNIOR, 2011, p.173).

Daí que, para os objetivos desta pesquisa, é relevante resgatar que O Direito Achado na Rua (ODANR) enquanto "escola de pensamento jurídico" (SÁ E SILVA online, 2015) em que situamo-nos. ODANR foi organizado na década de 1980 pelo professor José Geraldo de Sousa Junior sob inspiração do pensamento crítico do jurista Roberto Lyra Filho, autor da expressão ODANR. Enquanto movimento, surgiu a partir das demandas de assessorias jurídicas dos novos sujeitos coletivos. Assim, os processos político-jurídicos decorrentes da ação desses novos sujeitos sociais e seu reconhecimento no campo jurídico como sujeitos coletivos de direitos está na origem de ODANR, que inicia como linha de pesquisa vinculada à Faculdade de Direito da UnB e como curso de formação de assessorias populares:

[...] busca ser a expressão do processo que reconhece na atuação jurídica
dos novos sujeitos coletivos e das experiências por eles desenvolvidas de
criação de direito, a possibilidade de 1) determinar o espaço político no qual
se desenvolvem as práticas sociais que enunciam direitos ainda que contra
legem; 2) definir a natureza jurídica do sujeito coletivo capaz de elaborar um
projeto político de transformação social e elaborar a sua representação
teórica como sujeito coletivo de direito; 3 ) enquadrar os dados derivados
destas práticas sociais criadoras de direitos e estabelecer novas categorias
jurídicas (SOUSA JUNIOR, 2011, p.91).

Gohn, ao anunciar sua concepção de movimentos sociais, elenca o que considera serem seus elementos constituintes usualmente presentes, dentre os quais destacamos "bases, lideranças e assessorias" (GOHN, 2014, p.14, grifo nosso). Assim, a socióloga, uma das principais pensadoras e formuladoras brasileiras no campo de estudos sobre movimentos sociais, reconhece a relevância das assessorias a esses sujeitos, enxergando-os como elementos que integram a "luta sociopolítica, cultural ou econômica" com que os movimentos estão comprometidos.

\footnotetext{
${ }^{86}$ No que diz respeito a outros países da América Latina, referencia, em especial, o movimento zapatista no México, o movimento dos piqueteros - desempregados na Argentina, os movimentos indígenas na Bolívia e Equador, e o movimento de vizinhos na Venezuela (SOUSA JUNIOR, 2011, p.160).
} 
Cabe-nos concordar com a relevância das assessorias, em que pese compreendermos que desempenham um papel secundário em relação ao protagonismo das bases e lideranças dos movimentos, e reconhecer o Escritório Popular, objeto de análise desta pesquisa, nesse lugar. Ademais, retomando as falas das pessoas entrevistadas e as expressões elencadas para caracterizar os sujeitos com quem o EP atua, enxergamos nos pensamentos teóricos aqui referenciados e na escola de ODANR uma identidade de compreensões.

Por fim, mas não menos importante, tendo em vista que nossa perspectiva está vinculada à análise objetiva da realidade social, avaliamos que não podemos nos furtar de tecer breves comentários diretamente relacionados a essa questão que permeia o quefazer do EP e que perpassa o momento atual do cenário sociopolítico brasileiro. Como vimos, as ideias em torno da concepção de movimentos sociais, apesar de estarem sofrendo alterações desde os primeiros usos da expressão, ainda no século XIX, trazem em seu pano de fundo uma noção de contraponto à ordem vigente, a nosso ver uma noção de força contra-hegemônica e de resistência às relações de dominação e opressão da sociedade. Ou como apresentado nas falas das pessoas entrevistadas em nossa pesquisa de campo, sujeitos historicamente oprimidos e organizados coletivamente em torno de uma agenda de lutas por direitos.

No atual período da história brasileira, temos visto ações coletivas com diversas agendas políticas, culturais e/ou econômicas ocupando as ruas do país. Para pontuar uma compreensão nossa acerca desses sujeitos da atualidade, dos sujeitos com quem o EP atua e da pluralidade de compreensões acerca da concepção de movimentos sociais, explicamos que nosso entender é que não é qualquer coletividade organizada em torno de uma agenda política ocupando as ruas que se constitui como movimento social. Considerando as reflexões de Hinkelammert, Paulo Freire, Dussel, da escola jurídica que é O Direito Achado na Rua, o reconhecimento da coletividade de sujeitos como sendo um movimento social precisa, necessariamente, passar pelo horizonte de emancipação e libertação. Uma coletividade cuja agenda política congrega pautas de retrocessos de direitos para amplas parcelas da população, que ameaça direitos de trabalhadoras e 
trabalhadores, que defende hierarquia de seres, afetos, raças, não pode ser entendida como um movimento social ${ }^{87}$.

Não por acaso é possível observarmos em determinadas manifestações nas ruas cartazes com dizeres como "Basta de Paulo Freire!". A nosso ver, o fato de um dos principais pensadores da teoria do conhecimento e da educação desde uma perspectiva emancipatória e reconhecido mundialmente nesse lugar, ser um dos únicos nomes (de fora da política eleitoral) a figurar explicitamente em faixas - e para ser repudiado, é revelador de concepções dessas mobilizações: uma concepção que nega processos de libertação e emancipação dos sujeitos historicamente oprimidos no Brasil, ao contrário da compreensão de movimentos sociais que o EP e nós guardamos.

\subsection{Escritório Popular: uma ponte entre a extensão universitária e a advocacia popular}

Vimos até aqui que o EP é um projeto que integra um programa de extensão universitária, o Motyrum. Contextualizamos seu surgimento, os fatores que provocaram sua criação, os sujeitos com quem atua e alguns debates que perpassam seu quefazer.

Mas afinal, o que é o Escritório Popular? Qual é a sua composição e quais são as suas estratégias jurídico-políticas e concepções?

É com o objetivo de responder a esses questionamentos que desenvolveremos essa seção, utilizando diferentes técnicas de investigação científica: partiremos da pesquisa de campo (falas das pessoas entrevistadas e suas percepções sobre o EP) e passaremos por revisão bibliográfica relacionada ao tema para subsidiar nossas análises.

Antes de mais nada, é importante destacar, conforme percebemos nas falas das pessoas entrevistadas, que o EP não é, ele vem sendo. Isso porque o desenho do projeto em seu surgimento - seja em relação às integrantes, ao nível de organicidade com o Motyrum, ao método de ingresso de novas extensionistas, entre outros elementos - tem passado por mudanças constantes, decorrentes de

\footnotetext{
${ }^{87}$ Em tempo, nunca é demais afirmar e demarcar, partindo de nossa concepção de processos educativos como vinculados a intencionalidades políticas e de nossa noção de necessária ruptura com o mito da neutralidade como (falso) pressuposto epistemológico de pesquisas acadêmicas: Fora Temer!
} 
processos de ação-reflexão, além dos desafios concretos relacionados a questões como sustentabilidade, ambos os pontos próprios da extensão universitária. Outro aspecto que merece menção é a dificuldade que encontramos de achar informações sistematizadas e registros referentes ao EP. Avaliamos não ser esta uma característica particular do projeto, mas reveladora de um quefazer extensionista engajado cotidianamente em diversas agendas e tarefas, mas (ou talvez também como fruto desse acúmulo de afazeres) que nem sempre consegue manter a estrutura organizativa - registros, relatórios etc. - atualizada.

Interpretamos essa lacuna referente à sistematização escrita de registros sobre o projeto - e nossa vivência em outros projetos de extensão da UFRN e da UnB tem sinalizado nesse sentido - se trata de algo mais comum à extensão em si que atributo de um ou outro projeto e acreditamos que pode também ser relacionada à cultura de oralidade característica das práxis extensionista. Nossa hipótese é de que a pesquisa, por exemplo, ao exigir necessária e centralmente seus resultados sistematizados de forma escrita, contribui para uma cultura escrita de registros, anotações e relatórios.

Não estamos argumentando que o registro escrito e a sistematização das experiências não são relevantes para o quefazer extensionista. Ao contrário, esta pesquisa tem como uma de suas motivações o reconhecimento da importância de sistematiza-las. Diante dessas considerações, cabe explicitarmos que para o resgate histórico do EP recorremos, além da pesquisa de campo, a registros do projeto junto à PROEX/UFRN (disponíveis na plataforma digital SIGAA), grupo de e-mails do EP, atas de reuniões e relatórios.

A fim de facilitar a compreensão do desenho do EP e de suas transformações ao longo de seu percurso, elaboramos uma linha do tempo do projeto, elencando marcos que consideramos estruturantes, a partir de nossas análises das falas das pessoas entrevistadas e do levantamento documental. Trata-se de casos e/ou experiências avaliados como paradigmáticos por provocarem, de alguma forma, formulações e reformulações no EP. Tais marcos estão longe de esgotar o conjunto de ações em que o projeto esteve engajado ou as mudanças internas por que passou, porém, são representativos dos elementos principais que mais interessam a esta pesquisa: 


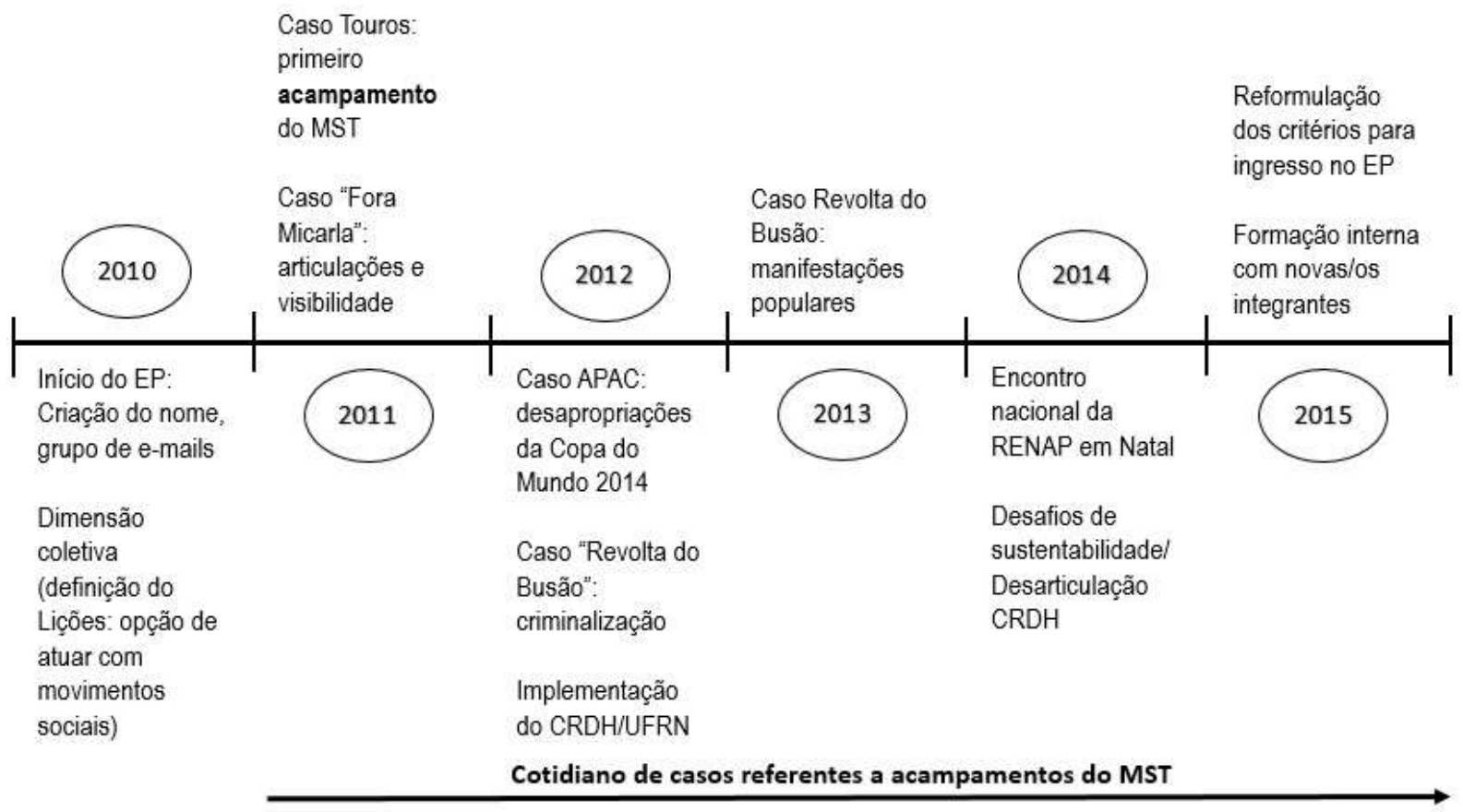

Figura 8: Linha do tempo do EP - Marcos estruturantes.

Fonte: Elaboração da autora.

O EP surgiu no âmbito do curso de direito da UFRN em 2010, conforme já detalhado no início do capítulo 2. Apesar de ter sido criado nesse ano, só veio a ser formalizado em 2011. Mesmo sem registro formal junto à universidade em seu primeiro ano de atuação, localizamos uma proposta de projeto de pesquisa apresentada ao Edital 002/2011 do Observatório da Justiça Brasileira ${ }^{88}$ pelo EP em parceria com a UFERSA e com a UERN ${ }^{89}$, que faz referência a seu início em 2010. A proposta pretendia, a partir dos cursos de direito das três universidades públicas do $\mathrm{RN}^{90}$ :

88 Sobre o Observatório, de acordo com sua apresentação no Edital 002/2011, disponível em < http://democraciaejustica.org/cienciapolitica3/sites/default/files/edital_002-2011_final.pdf>: "A proposta de organizar um Observatório da Justiça no Brasil nos moldes de outras experiências internacionais tem sido uma preocupação tanto do governo quanto da sociedade civil no país. $\mathrm{O}$ fundamento da ideia de observação da justiça está ligado a um conjunto de problemas suscitados por fortes mudanças ocorridas tanto no contexto internacional quanto no contexto nacional. Com o intuito de contribuir com esse debate foi criado no ano de 2010, o Observatório da Justiça Brasileira (OJB), com gestão do Centro de Estudos Sociais América Latina (CES-AL) e sede na Universidade Federal de Minas Gerais - UFMG". Sobre a relevância de um Observatório para a justiça brasileira, recomendamos a publicação da Série Pensando o Direito (Ministério da Justiça, 2009) coordenada pelo professor José Geraldo de Sousa Junior Observar a Justiça: Pressupostos para a Criação de um Observatório da Justiça Brasileira.

${ }^{89}$ A parceria com a UFERSA dava-se/dá-se com o Grupo de Estudos em Direito Crítico, Marxismo e América Latina dessa universidade, coordenado pelo professor Daniel Valença; já com a UERN, a parceria ocorria, pois, um dos advogados que acompanhou o EP entre 2011 e 2012, João Paulo Medeiros, era professor do curso de direito dessa instituição. Ambos os professores são integrantes da RENAP.

90 Destacamos o diálogo e interlocução do EP com outros cursos de direito de universidades públicas do RN (UFERSA e UERN), ao mesmo tempo em que constatamos a ausência total de relação com o curso de direito da própria UFRN localizado no campus de Caicó, no sertão do estado. Esse 
[...] [investigar] a atuação do Poder Judiciário no estado do Rio Grande do Norte perante os conflitos agrários e as novas práticas jurídicas demandadas pelos movimentos sociais e pela advocacia popular" e apresentava o EP como atuando "desde 2010 prestando assessoria jurídica popular para movimentos sociais na capital e em diversas cidades do interior do Estado do Rio Grande do Norte.

De seu início, em 2010, até meados de 2011, o EP contava exclusivamente com estudantes da graduação do curso de direito, não havia advogadas ou advogados no projeto (como viria a ter mais adiante). Quando era necessária a atuação em audiências ou em procedimentos exclusivos da advocacia, as estudantes buscavam amigos recém-formados - que por vezes sequer atuavam profissionalmente como advogados - para suprir essas demandas pontuais. Mas eram as e os extensionistas que faziam o trabalho cotidiano de assessoria, sem acompanhamento de advogados ou professores (do diálogo com os sujeitos assessorados à produção de peças, passando pelas pesquisas e discussões sobre as teses jurídicas e debates políticos de fundo). Ou, nos primeiros casos, foram buscados os próprios professores para assinar as petições. Como lembra E4:

No começo ali só tinha... eu lembro que era um perrengue para achar gente para assinar as peças, éramos todos estudantes. [...]

A gente tem uma contribuição técnica que não era utilizada, a gente começava a se motivar a pensar alternativas para aplicação daquele conhecimento e íamos para um espaço [EP] que a gente poderia, enfim, judicializar com pessoas que estavam se formando ou formadas, que estavam dispostas a assinar a peça... o que era algo difícil também, porque você entende que havia limitações da Prática jurídica, né? De um professor assinar as peças, de ele se comprometer com uma causa que claramente não é só jurídica, que é política, que para ele é um mundo estranho dialogar com os dois... ele tem muita dificuldade. Ele eu digo no geral, né? Ele e ela, enfim, professor e professora do curso de direito, de dialogar com essas duas realidades e de reconhecer que existe, que deveria estar à frente, tanto que a gente teve dificuldade nas orientações também...

Nesse sentido, cabe a reflexão sobre a indisponibilidade de tais casos serem acompanhados pelo NPJ apesar do fato deste dispor tanto de professores e professoras, como de advogadas. Essa indisponibilidade era reflexo das limitações de estrutura do Núcleo e, a nosso ver, também das decorrentes às concepções em

elemento não surgiu nem nas entrevistas, nem na pesquisa documental, mas ficou evidente em nossas análises. Não foi um aspecto em que nos detivemos, mas deixamos a sugestão para futuras investigações: perspectivas de ensino, pesquisa e extensão e de possibilidades de diálogo entre os dois cursos de direito da UFRN (campi de Natal e de Caicó). 
questão ${ }^{91}$, que serão abordadas no capítulo 3 . Atuar nos casos do EP, como explicitamos no item anterior, tratava-se também de uma aliança política com os sujeitos oprimidos, o que extrapola a delimitação de assistência gratuita proposta pelo NPJ92.

Como afirmou E2 em sua entrevista, "a gente levou para a Prática Jurídica os primeiros casos coletivos da Prática Jurídica da UFRN", referindo-se ao início do EP e das tentativas de parceria com o NPJ, conforme mencionamos ao situar o surgimento do projeto, no início deste capítulo. Sobre essa relação com o NPJ, E4 conclui que "você só tem o Escritório Popular porque a Prática Jurídica falhou; em determinado momento ela não supriu uma demanda que já existia, de um públicoalvo que já existia e foi necessário criar ali [o EP]”. Ainda sobre essas questões, E3:

E, por outro lado, começaram a chegar demandas que a Prática [NPJ] realmente não ia ter como... no começo nosso principal... no começo não, até hoje, nosso principal demandante é o MST. E aí a prática da UFRN só pegava casos de Natal.

$[\ldots]$

É porque eu acho que a gente não confia na formação do curso de direito da UFRN para passar casos de movimento social. Questões coletivas eu acho que seria possível que a gente talvez... se ainda tivesse relações com... talvez questões coletivas seria possível que se encaminhasse [para o NPJ]. Mas causas de movimentos sociais eu não visualizo a gente encaminhando porque eu não confio na formação de quem tá ali, de que não vai reproduzir opressões, entendeu? Praqueles movimentos... Não que eles não soubessem responder a isso [risos]. Mas eu jamais cogitaria mandar um caso do MST para a Prática ${ }^{93}$.

Foi ainda em 2010 que foi definido o nome do projeto, criado o grupo de emails para comunicação interna das extensionistas e iniciou-se uma dinâmica de reuniões periódicas. Encontramos, em uma ata de reunião de novembro desse ano,

91 Um dos principais impedimentos alegados para que o NPJ da UFRN atuasse com os casos do EP era a questão da área atendida pelo Núcleo, que era restrita à cidade de Natal - o que já excluía, por exemplo, todos os casos do MST, e, ainda assim, excluía a zona norte do município (que é a zona administrativa com maior população da cidade, concentrada principalmente entre as classes baixa e média baixa). O NPJ da UFRN localiza-se no campus central da universidade, situado na zona sul de Natal, que em 2008 possuía renda média de mais de onze salários-mínimos. Considerando que um dos critérios para atendimento no NPJ é o de renda igual o inferior a dois salários-mínimos, evidencia-se o distanciamento entre as demandas da população de Natal e o Núcleo, que é localizado mais próximo da população economicamente menos vulnerável da cidade - que está longe de ser o perfil de quem precisa de um NPJ, mas próximo ao perfil de estudantes do curso de direito da UFRN (http://www.tribunadonorte.com.br/noticia/perfil-de-estudantes-da-ufrne-jovem-branco-e-egresso-da-rede-privada/107488).

92 Não pretendemos aqui ignorar questões relevantes como a remuneração de docentes, seu regime de trabalho e a possibilidade de advogar, a carga horária de trabalho de advogados e advogadas do NPJ, entre outros aspectos. Mas não desenvolveremos esses aspectos por fugirem do foco de nossa pesquisa. Nossa crítica é ao modelo do paradigma dominante de direito manifestado pela atuação do Núcleo, não à equipe de profissionais em si.

93 "Prática" é o termo normalmente usado para se referir ao Núcleo de Prática Jurídica da universidade. 
um registro com a definição de que a abrangência de atuação do EP compreenderia "questões coletivas do Rio Grande do Norte (Grande Natal, assentamentos indicados pelo "Lições" etc.) ". Essa delimitação nos remete a dois elementos:

i) A dimensão coletiva de que tratamos no item anterior - sobre os sujeitos com quem o EP escolheu atuar, e

ii) A perspectiva de ser um núcleo para assessorar juridicamente as demandas coletivas dos demais núcleos do "Lições" (assentamentos rurais, comunidades urbanas, etc.).

Como expusemos no início do capítulo 2, um dos fatores desencadeadores da criação do EP foram as demandas por assessoria jurídica no âmbito do sistema de justiça dos núcleos de educação popular do Lições de Cidadania/Motyrum. Nesse momento, de início de projeto, as questões eram relacionadas a demandas coletivas para a garantia de direitos como mobilidade urbana (acompanhamento da agenda de aumento da tarifa de transporte público de Natal sem contrapartidas de licitação e de melhoria da qualidade do serviço oferecido à população, por exemplo), educação (transporte público escolar para conjunto habitacional acompanhado pelo núcleo urbano do programa), saúde (mediação para garantir coleta de lixo em assentamento em que núcleo rural atuava) etc.

Ainda sobre a reunião de novembro de 2010 , chamou nossa atenção o fato de que naquele momento foi indicada a necessidade de se construir coletivamente o registro formal do projeto junto à universidade. Tal proposta seria encaminhada apenas por volta de setembro de 2011 e a UFRN só a aprovaria meses depois, de forma que o reconhecimento formal da existência do projeto pela universidade deuse apenas a partir de 2012, em que pesem os casos com repercussão na mídia local antes disso (como o "Fora Micarla", em que o EP fez a assessoria jurídica da ocupação da Câmara Municipal de Natal, gerando notícias até na mídia nacional, como veremos mais adiante $\left.{ }^{94}\right)$.

Essa questão, a nosso ver, é reveladora do compromisso e engajamento das extensionistas do projeto. O EP demorou mais de um ano - de seu início ao reconhecimento formal pela universidade - para ser registrado e, portanto, deixando

${ }^{94}$ Conferir Folha de São Paulo: <http://www1.folha.uol.com.br/poder/930630-stj-garante-continuidadede-protesto-na-camara-de-natal.shtml>, Instituto Humanitas Unisinos: $<$ http://www.ihu.unisinos.br/noticias/44723-fora-micarla-movimento-nasceu-e-cresceu-nas-redessociais>; Carta Capital: <http://www.cartacapital.com.br/politica/movimento-pede-impeachment-daprefeita-de-natal>, Estadão: <http://politica.estadao.com.br/noticias/geral,stj-decide-pela-naodesocupacao-da-camara-de-natal-rn,733071>. 
de "existir", institucionalmente, para a UFRN. Essa não formalização repercute de modo negativo ao projeto pois não registra na instituição as atividades que, de fato, são realizadas pela extensão na comunidade, além de impedir que as estudantes extensionistas tenham reconhecido e certificado a sua participação em atividades dessa gama e complementares à grade curricular oficial. Esse não reconhecimento é emblemático em um contexto educacional tecnicista que é centrado na dimensão do ensino em sala de aula e, em boa medida, castra outras possibilidades de diálogo e construção de saberes e conhecimentos. Além disso, a ausência de registro impossibilita o acesso do projeto às fontes de financiamento para a sua estruturação, inibindo a disputa por editais, por exemplo.

Apesar de todas essas restrições, em nenhum momento isso se constituiu como óbice para que as estudantes dedicassem de forma cotidiana e engajada com suas atividades. Elencamos essa percepção como uma característica própria da extensão popular, ou seja, da extensão universitária que atua com os sujeitos oprimidos que a adjetivam dessa forma, conforme vimos no item anterior deste trabalho. Como contraponto a essa perspectiva, observamos outras concepções de extensão universitária ${ }^{95}$ em que não há participação de extensionistas sem prévio anúncio de distribuição de certificados (e, portanto, não existe engajamento extensionista anterior à formalização do projeto). São perspectivas de extensão que partem de processos, em geral, verticalizados e/ou voluntaristas, "coisificantes" de estudantes, na contramão da concepção educativa que se pretende emancipatória e promove processos de genteficação.

Ao mesmo tempo, esse processo longo de formalização que se estendeu por meses revela-se como sintomático do desafio de conciliação das demandas organizativas da extensão diante das exigências da burocracia universitária. Parece haver um descompasso entre as demandas cotidianas da extensão popular, oriundas da agenda de intensa mobilização popular, e o ritmo impresso e exigido pela universidade para lidar com elas. Talvez seja igualmente sintomático do lugar que a extensão ocupa hoje na universidade, uma vez que rotinas administrativas

95 Para um breve resgate histórico da extensão universitária e de suas diferentes concepções, conferir SERRANO (2011). A autora pontua a existência de ao menos quatro momentos expressivos de sua conceituação e prática: o modelo da transmissão vertical do conhecimento; o voluntarismo, a ação voluntaria sócio-comunitária; a ação sócio-comunitária institucional; o acadêmico institucional e desenvolve cada modelo desde uma perspectiva histórica. 
mais ágeis são mais comuns ao ensino, por exemplo, em que pese o princípio constitucional da indissociabilidade de ensino, pesquisa e extensão.

O início dos trabalhos do EP antes mesmo de sua formalização revela ainda outro aspecto: o recorte de classe de estudantes que não precisavam de bolsa para conseguir se dedicar à extensão. Daí também por que o encontro com os sujeitos historicamente oprimidos ser transformador, visto que era o encontro com realidades muito diversas das dos estudantes (sobretudo no que diz respeito à classe e à dimensão rural, já que parte significativa dos casos são referentes à realidade rural, em contraponto à realidade urbana em que vivem as extensionistas). Ao reconhecer o recorte de classe do curso de direito (e da universidade pública), E3 formula uma crítica à concepção de educação jurídica hegemonicamente presente no Brasil:

\begin{abstract}
Se o curso de direito já tem o filtro de classe na própria entrada, especialmente na Universidade Pública, acaba significando que são pessoas distantes da realidade da maioria da população, são pessoas que têm oportunidades que a maioria da população não tem... já começa o filtro antes, quando chega no curso não é reforçado, por exemplo, a extensão. Não é reforçado você conhecer a comunidade, é reforçado você estudar para tirar notas boas e você produzir artigos pra, enfim, seu Lattes. Então esse distanciamento da realidade é reforçado; se já teve no filtro do acesso, é reforçado nessa subvalorização da extensão e nessa patética permissão de que evento, palestra, sejam projetos de extensão. Que vai contra o Estatuto da UFRN, inclusive [...]. E aí, enfim, depois de se formar, de estudar pra concurso público, pronto, é a cristalização da "bolha". O que vinha no processo de "faço direito, não preciso conhecer a realidade, não preciso pisar no chão" se cristaliza aí... Eu acho que até no curso de medicina as pessoas têm mais acesso às comunidades, às populações vulneráveis, do que o curso de direito. Você só tem acesso a esse tipo de realidade, no curso de direito, se for absolutamente por iniciativa própria sua, não tem nada que the vincule... A Prática Jurídica é na Universidade [dentro do campus], não tem nada que faça que você se forme tendo que ter passado, alguma vez, por uma comunidade vulnerável. [...] E aí isso vai seguir, depois, na forma de seleção pra concurso público que a gente ouviu de um - acho que tu estava nessa... - juiz, era um juiz? Que saiu de casa e alugou um kitnet pra se isolar até da família e estudar dezoito horas por dia sem ter nem... nada, nada ... Ou seja, se alienar totalmente da realidade onde vive. Mas isso é só a cristalização de um processo que começa antes. (E3)
\end{abstract}

Por outro lado, considerando que os territórios dos casos do MST eram fora do município de Natal e exigiam deslocamento, era fundamental poder contar com recurso para subsidiar minimamente os custos de atuação. À época, apesar de não ter como sequer acessar editais, por não ter proposta formalizada, como o EP surgiu dentro do Programa Lições de Cidadania, foi possível utilizar recursos que o Lições tinha, fruto de proposta aprovada em edital do Governo Federal. Tal possibilidade foi imprescindível para garantir questões básicas como transporte, como pontua E2: 
Não tinha transporte pra Macaíba ${ }^{96}$. Era nos nossos carros. Nem gasolina. A gasolina era do Lições. [...] E aí pra isso a gente conseguia fazer via Lições, entendeu? Aí com mais liberdade política e de ter as decisões e a gente estar na rédea mesmo do negócio[...], a gente tinha o dinheiro do Lições. [...]. Então a gente podia ir pra qualquer lugar, a ação em qualquer lugar que a gente fazia. Xerox, fazia tudo. Hoje em dia a gente pede, coitado, a gente pede pra o pessoal a xerox do MST. Porque não tem como trazer uma, fica mais, fica muito caro, trazer o processo pro $\mathrm{CRDH}$, tirar cópia no CRDH e depois devolver pra o interior dele. Então, assim, é melhor tirar por lá mesmo. É "foda". Nem isso, aí o Lições hoje não tem esse recurso, o CRDH também esse ano não tem. (E2)

Analisando a trajetória do EP e fazendo o levantamento de casos em que o projeto atuou, verificamos como a atuação com o MST desempenhou (e desempenha) um papel relevante também no que diz respeito à expansão territorial do quefazer do EP. Os únicos casos do projeto fora do município de Natal foram os relativos a conflitos do MST, majoritariamente envolvendo questões possessórias e/ou criminalização do movimento. Com o objetivo de facilitar a visualização de como a assessoria jurídica ao MST expandiu a região de atuação do projeto para além do município de Natal, fizemos o seguinte mapa:

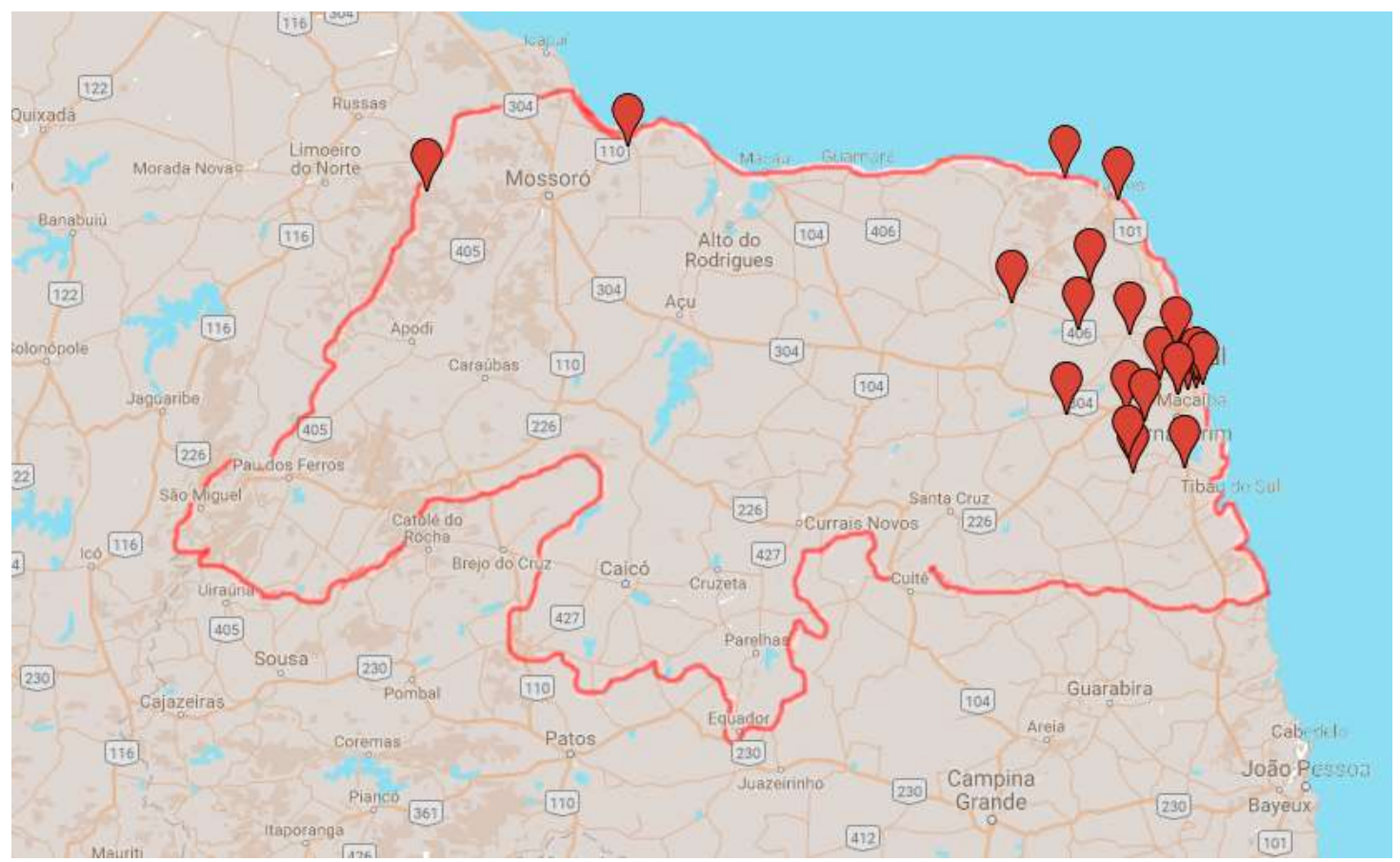

Figura 9: Mapa com casos do EP $(2010$ - 2014)

Fonte: Elaboração da autora com colaboração de Étore Medeiros.

${ }^{96}$ Macaíba é um município da Grande Natal e onde é situado o assentamento rural Caracaxá, cujas demandas relacionadas à coleta de lixo e ao abastecimento de água foram fundantes para o EP, conforme mencionamos ao contextualizar o surgimento do projeto, no início do capítulo 2. 
Passados os primeiros meses de organização interna e debates, um marco inicial estruturante para as integrantes do EP foi o primeiro caso de um acampamento do MST, localizado em Touros (município distante $85 \mathrm{~km}$ de Natal), que chegou em março de 2011 como demanda para o projeto. Esse caso foi paradigmático para as integrantes do EP, por ter proporcionado um primeiro contato com o sistema de justiça de forma mais ampla (da oficiala de justiça ao juiz, passando pela delegacia de polícia e pelo Ministério Público).

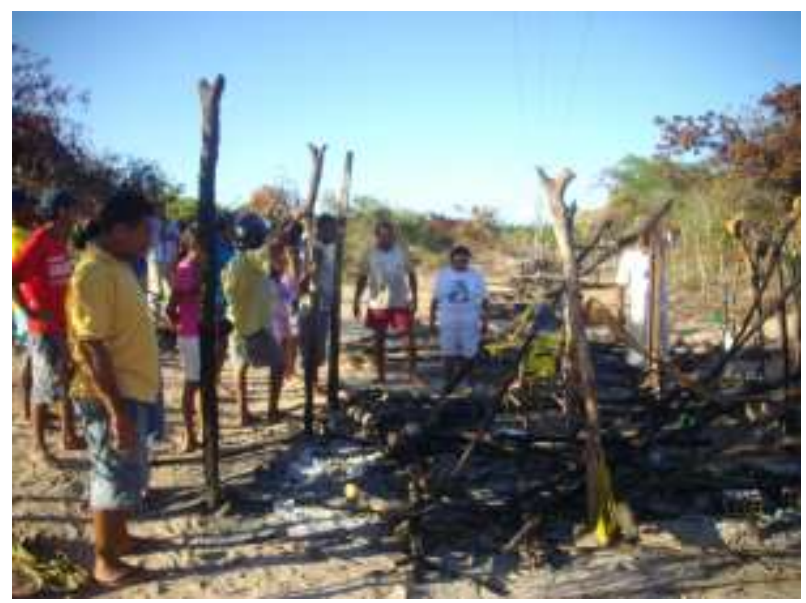

IMAGEM 5: Acampamento do MST queimado em Touros/RN

FONTE: Arquivos do projeto.

A questão chegou ao EP para fazer cumprir a decisão liminar de reintegração de posse, a oficiala de justiça não apenas permitiu que policiais e jagunços contratados pelo proprietário da terra ateassem fogo aos barracos das trabalhadoras e trabalhadores do MST, como registrou a queima nos autos, demonstrando a naturalização do episódio que destruiu tudo o que as famílias tinham.

E2 resgata o ocorrido, revelando como o caso foi paradigmático para as extensionistas:

O que acontece foi o que aconteceu com Touros e assim nasceu [o EP], [com] o MST dizendo que ia ter uma reintegração de posse. Quando a gente foi ver o processo já tinha passado o prazo de tudo... contestação, tudo! Já era bem a segunda ou terceira reintegração de posse. Tirava, eles voltavam, tirava, eles voltavam. E aí foi a partir do momento que a gente acompanhou, inclusive, a reintegração de posse, foi um negócio muito violento, assim... [...] A gente fez agravo..., mas aí a reintegração de posse foi "foda" porque eles queimaram... foi assim, foi uma sacanagem mesmo. No oito de março, as mulheres e a comunidade vieram [de Touros para Natal] para um ato na Assembleia e a partir disso eles [oficiala de justiça, polícia, jagunços] fizeram a ação [de cumprimento da liminar de reintegração] aproveitando o acampamento vazio. Claro, tinham as seguranças, a brigada lá, que fazia a 
segurança. Mas não teve como conter e como não tinha pessoas pra tirar as coisas de dentro eles queimaram os barracos com as coisas dentro. Então roupa, material até de, eu me lembro que tinha coisa de material escolar também, eu acho que é por causa do início do ano letivo estava tudo... muita coisa foi queimada. E a Oficiala de Justiça colocou isso no termo...Que queimou e tudo e registrou isso e isso foi interessante. Por quê? Porque aí quebrava aquele romantismo, de quem tinha ainda, do Direito e tal... "Ah, isso pode?". É, na verdade isso é o que parece que pode, realmente. Então, foi assim, o início foi esse, foi o choque assim, da gente "Pô, não funciona nada!". E aí, é uma decisão absurda, [que determinava] um raio de $80 \mathrm{~km}^{97}$ que a gente foi fazer as contas e era fora do município. Então, assim, as pessoas eram, foram praticamente expulsas. (E2)

A partir desse caso, o cotidiano do EP passou a ser permeado por demandas contínuas do MST. Se quiséssemos construir uma linha do tempo exclusiva de casos do MST desde o surgimento do projeto até hoje, ela seria praticamente ininterrupta e contaria com pelo menos metade de todos os casos em que o projeto já atuou. Segundo o levantamento que fizemos na pesquisa, no período analisado - de seu surgimento em 2010 até março de 2015) o EP atuou em 27 (vinte e sete) $\operatorname{casos}^{98}$, dos quais 15 (quinze) são do MST. O MST é o sujeito permanente com quem o EP atua. Essa constatação nos coloca a seguinte provocação: apesar de ser evidente a predominância do MST na agenda do projeto, dos 16 (dezesseis) casos elencados pelas pessoas entrevistadas (cada pessoa foi instada a indicar dois casos) como os mais representativos em relação a experiências bem-sucedidas de democratização da justiça, 14 (catorze) casos foram comuns nas respostas, nenhum deles do MST.

A segunda provocação que o caso Touros nos coloca é que antes dele, a atuação do Lições de Cidadania/Motyrum era concentrada em assentamentos rurais do MST. A partir dele, além do trabalho de educação popular em direitos humanos do núcleo rural do Motyrum - que continua em assentamentos do MST, a atuação do EP passa a ter um cotidiano junto ao Movimento, porém, predominantemente em acampamentos. Essa percepção nos arranca a análise do desafio colocado em relação à realização de reforma agrária: enquanto nos assentamentos já houve a conquista da terra pela agricultura familiar e a luta é por outros direitos, no caso dos

\footnotetext{
97 A decisão judicial de liminar em reintegração de posse não apenas determinou a saída das famílias da terra ocupada, como arbitrou uma distância a ser observada pelas famílias, que não poderiam ficar a menos de $80 \mathrm{~km}$ (conferir) do território, sendo que essa distância estabelecida implica na própria saída do município.

${ }_{98}$ Cabe destacar que nos referimos a 27 territórios, não a 27 processos judiciais, de forma que, por exemplo, há acampamento ou desapropriações como as da Copa que contabilizei como representando um caso cada, mas houve mais de uma ação judicial em cada situação. Além disso, destacamos que a dificuldade de encontrar informações sistematizadas é possível que tenha havido mais casos que não conseguimos localizar.
} 
acampamentos a situação é alarmante, pois luta-se pela garantia do direito à terra; não há sequer o território conquistado, é uma etapa anterior.

O terceiro elemento provocador do caso Touros é que ele foi paradigmático para as e os integrantes do EP também no que se refere ao desvelamento do Judiciário, e mais amplamente, do sistema de justiça. Como registrado no grupo de e-mails do EP por uma de suas integrantes à época, ao comentar notícia de despejo de acampamento do MST em Pernambuco, "qualquer semelhança com nosso caso não é mera coincidência, é a criminalização dos movimentos na prática... triste ver essa violência e tantas violações" (grifo nosso). Ou seja, o caso de Touros mostrou-se como emblemático na medida em que foi um dos primeiros contatos com a questão da criminalização dos movimentos sociais e que permitiu a identificação de um padrão criminalizante pelo sistema de justiça ao lidar com esses sujeitos, como revelou E3:

\begin{abstract}
Mas o caso mais simbólico, eu ia dizer Touros, porque foi o nosso primeiro choque de realidade, mais severo, eu acho. Porque uma coisa era Caracaxá, "tudo bem", a conta chega, mas a água não chega, a gente já estava percebendo que as coisas, na prática, eram diferentes. Mas Touros foi muita violação em cima de violação e a gente não pôde fazer nada, praticamente, porque já estava... [...] Touros já estava em fase de apelação quando a gente entrou em contato, ou seja, antes do Escritório Popular eles não tiveram acesso a nenhuma defensoria, nenhum outro advogado, nem o Ministério Público. (E3)
\end{abstract}

Na mesma linha, E5 demonstrou seu incômodo e choque a partir dessa experiência, por ter evidenciado que sequer o direito positivo infraconstitucional e as garantias processuais são respeitadas quando o sujeito é um movimento social:

[...] uma questão que me incomodou muito no Escritório Popular, que era a
não... A falta de garantias processuais, o tratamento que era dispensado
aos movimentos sociais no judiciário como um todo, né? [...] dois casos que
para mim foram casos emblemáticos... não é emblemático... mas que isso
ficou mais evidente, para mim, que foi o caso de Touros, e foi um caso que
eu acompanhei de São Gonçalo, que eu fiz o agravo, e ai eu ficava olhando
assim o absurdo que eu tava vendo, porque nada... aquela decisão não
tinha razão de ser, ela não tinha fundamento, ela não tinha... Enfim... Era...
Não era só rasgar a Constituição com relação à função social da
propriedade, era rasgar o próprio código de processo civil, né? A própria
contradição, a gente viu a própria contradição nesse espaço. (E5)

Além do conflito de Touros, elencamos como casos emblemáticos para a linha do tempo do EP o "Fora Micarla", o das desapropriações para implementar o projeto de mobilidade urbana para a Copa do Mundo 2014 em Natal e a "Revolta do Busão". Ao perguntarmos às pessoas entrevistadas quais dois casos elas consideram mais bem-sucedidos em relação à democratização da justiça, olhando 
para o percurso do EP, das 16 (dezesseis) respostas, 7 (sete) foram o caso do "Fora Micarla" e outras 7 (sete) foram "o caso da Copa", referente à assessoria à Associação Potiguar dos Atingidos pela Copa (APAC) contra as desapropriações previstas para o projeto da Copa do Mundo de 2014 em Natal.

A atuação do EP junto à APAC caracterizou-se pelo assessoramento realizado junto às famílias residentes na mesma comunidade e que foram unidas por uma articulação política movida em resistência às remoções eminentes a partir de 2011, no contexto de organização dos jogos da Copa do Mundo em 2012. O projeto de remoção que foi oficialmente chamado de projeto de mobilidade urbana para a Copa do Mundo em 2012 em Natal/RN, significava para mais de quatrocentas famílias um projeto de remoção das casas onde viviam. Essas famílias precisaram se organizar politicamente para resistir às remoções e foi esse processo de mobilização política de luta que deu origem à APAC. Embora a resistência às remoções estivesse inicialmente na centralidade da luta política da associação, o processo de organização e politização da APAC, articulado com a agenda do Comitê Popular da Copa - que, inclusive, passou a constituir - constituiu uma agenda de lutas da associação ampliada para outras questões relativas às violações de direitos.

O EP aproximou-se do Comitê Popular da Copa, passou a acompanhar os debates políticos realizados em torno desse projeto, e tornou-se a referência em assessoria jurídica a partir dos debates políticos. No caso da APAC, assessorou desde a organização e constituição da associação, até os processos judiciais (individuais e coletivas), passando por audiências públicas, atos e intervenções políticas em geral.

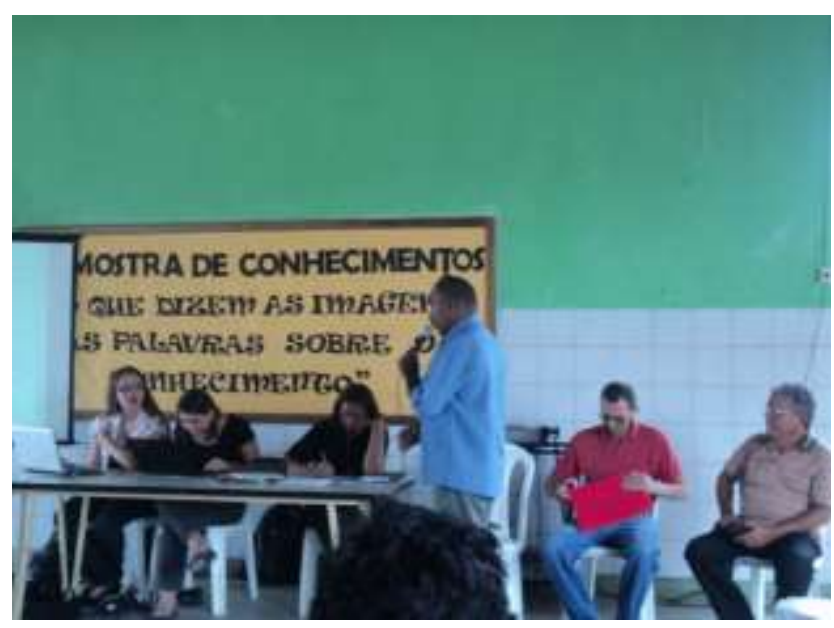

IMAGEM 6: Assembleia instituinte da APAC - 1 FONTE: Arquivos do projeto. 


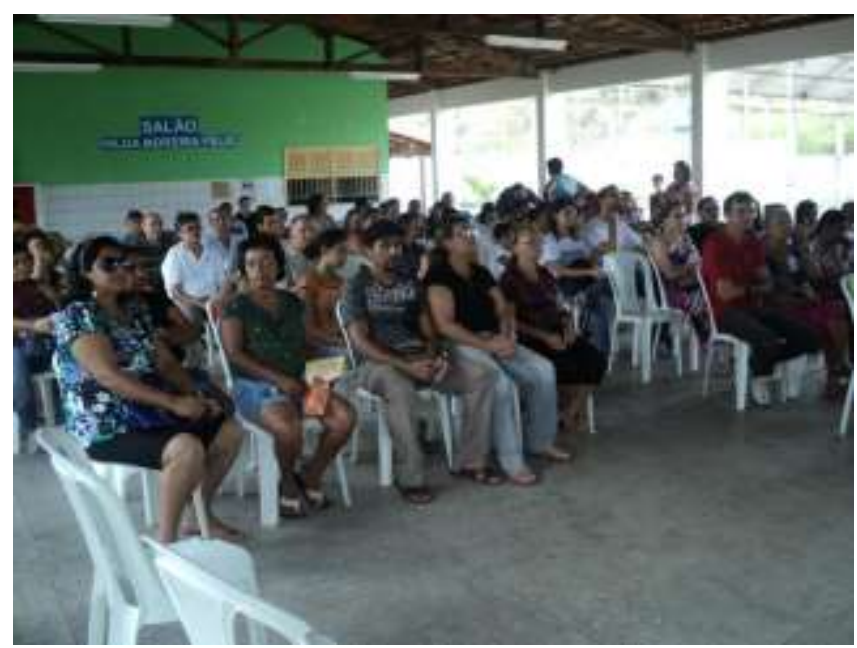

IMAGEM 7: Assembleia instituinte da APAC - 2

FONTE: Arquivos do projeto.

Outra atuação do Escritório Popular que foi mencionada nas entrevistas foi a ocupação da Câmara Municipal de Natal pelo movimento "Fora Micarla", em junho de 2011, que reuniu elementos estruturantes para o desenrolar do projeto daí em diante. Conforme explica SOUZA (2014), contextualizando o movimento:

\footnotetext{
O \#ForaMicarla se materializou em seus primeiros protestos a partir de uma problemática que historicamente mobiliza o movimento estudantil: 0 transporte público. Quase todos os anos tinha aumento no valor das passagens de ônibus, mesmo sem a condicionante da melhoria no serviço, e quase todos os anos havia protestos contra a subida das tarifas, mas em 2011 foi diferente.
}

A soma de desmandos da prefeitura, a falta de respostas convincentes da administração municipal e a forma como eram tratados quem buscava essas respostas, tudo isso repercutindo nos veículos de comunicação (tradicionais ou blogs), foi gerando na população um imenso descontentamento.

Para organizar a ocupação o movimento se organizou em comissões, e o escritório popular passou a ser o responsável pela área jurídica. As atividades desenvolvidas no âmbito dessa comissão foram diversificadas e incluíram assessoramento jurídico, em sentido amplo, e judicial, com impetração de habeas corpus no Tribunal de Justiça do Estado do Rio Grande do Norte e, posteriormente, no Superior Tribunal de Justiça. É importante destacar que nesse caso o EP elaborou a defesa jurídica - peça vitoriosa no STJ que evitou a reintegração de posse do espaço - e participou de toda a articulação com o Conselho Estadual de Direitos Humanos e com a Ordem dos Advogados do Brasil em Natal. 


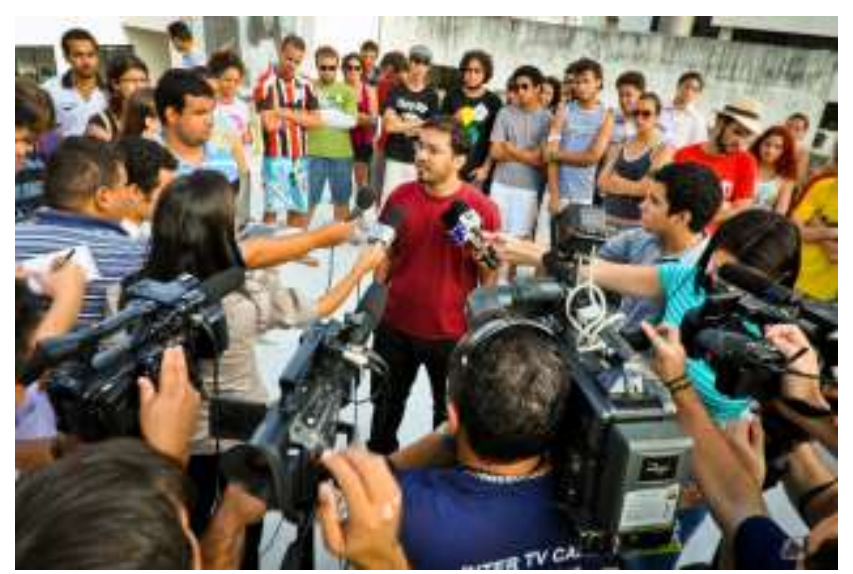

IMAGEM 8: Coletiva de imprensa da comissão jurídica durante a ocupação da câmara municipal de natal pelo movimento fora micarla FONTE: arquivo do projeto

Dos outros dois casos mencionados nas entrevistas, um foi referente a acampamento do MST e o outro à "Revolta do Busão".

A "Revolta do Busão" trata-se de um movimento surgido em Natal em 2012 como decorrência do aumento da tarifa do transporte público na cidade. Desde então, a cada anúncio de alta no valor da passagem de ônibus, são retomadas as manifestações que ocupam as ruas da capital potiguar com protestos. Um texto de apresentação do movimento revela ao menos dois elementos que chamam atenção para a compreensão desse processo: i) constituiu-se ao mesmo tempo como legado do movimento "Fora Micarla" e como um dos antecedentes das manifestações de junho de 2013 - maiores mobilizações de rua no Brasil desde o "Fora Collor" - e ii) foi fortemente marcada por repressão policial a manifestantes:

Eu existo desde 2012, vocês mesmo já sabem, quando ainda me chamavam pelo nome. Vocês podem acessar o verbete "Protestos no Brasil em 2013" da Wikipedia, em Antecedentes, e verá que há o seguinte comentário sobre mim:

Em 27 de agosto de 2012 a prefeitura de Natal (RN) anunciou um aumento de $R \$ 0,20$ na passagem de ônibus. Após o anúncio, houve uma série de manifestações organizadas pelo movimento social autodenominado "Revolta do Busão" (nas redes sociais: \#RevoltadoBusão). A primeira manifestação ocorreu dois dias depois, reuniu cerca de duas mil pessoas e foi duramente reprimida pela polícia militar. No dia 30 de agosto de 2012 o protesto voltou com mais força, mas sem confrontos com a polícia militar. Com a pressão popular, no dia 6 de setembro de 2012 os vereadores revogaram o aumento da tarifa de ônibus.

Mas na verdade descendo do \#ForaMicarla, que ocupou a Câmara municipal em 2011. Graças a mim a passagem em Natal ficou congelada por anos, fui o arquétipo dos protestos de junho de 2013 no Brasil. 99

99 Disponível em <http://www.cartapotiguar.com.br/2015/07/28/ola-imprensa-natalense-sou-a-revoltado-busao-prazer-em-conhece-la/>. 
Em decorrência da repressão policial, foram deflagrados processos de criminalização de manifestantes do movimento e o EP atuou num primeiro momento assessorando juridicamente essa questão (a partir de 2012) e, de forma marcante, garantindo o direito de que manifestantes ocupassem as margens da BR-101 nos protestos, num segundo momento (2013). Essa conquista, em plena conjuntura de protestos de junho de 2013 explodindo no Brasil, colocou a atuação do EP novamente em notícias da mídia nacional ${ }^{100}$, pois a assessoria do projeto ao movimento conquistou a decisão que permitiu o direito de manifestação na rodovia no âmbito do Superior Tribunal de Justiça (STJ), revertendo decisão do Judiciário local (da mesma forma que no "Fora Micarla", em 2011).

Casos como a "Revolta do Busão", o "Fora Micarla" e o "caso da Copa" referente sobretudo à atuação para impedir as desapropriações de imóveis residenciais previstas para efetivar o plano de mobilidade urbana para a Copa do Mundo 2014 em Natal - são reveladores de como o quefazer do EP tem estado vinculado à conjuntura política dos conflitos em Natal. Essa dimensão do projeto é causa e consequência das concepções que o perpassam e da aliança política com os sujeitos oprimidos que é basilar para sua práxis e tem sido relevante também para que o EP venha se estabelecendo como referência em assessoria jurídica popular a conflitos de direitos humanos na cidade.

Nesse sentido, avaliamos como emblemático para a caminhada do EP que Natal tenha sediado, pela primeira vez, o encontro nacional da RENAP em 2014, momento que a rede completou dezenove anos. A nosso ver, tal fato tem relação direta com o surgimento e atuação do EP no estado do RN. Isso porque é clara a percepção das pessoas que entrevistamos sobre já existirem advogados da RENAP no estado antes da criação do EP. Porém, o projeto potencializou a assessoria jurídica popular, na medida em que se tornou um "sujeito coletivo na advocacia popular" (E8). Ou seja, a dimensão coletiva refletiu-se também na organização do projeto, tendo em vista que a horizontalidade, o diálogo, a perspectiva de enxergar o próprio quefazer desde uma ótica de construção necessariamente coletiva, forja sujeitos coletivos de advocacia popular, que como tais, aumentam as possibilidades de intervenção da assessoria jurídica na realidade local. São nessa linha, as reflexões de E3:

100 Conferir: Conjur: <http://www.conjur.com.br/2013-jun-20/liminar-superior-tribunal-justica-liberamanifestacao-natal>; e G1: < http://g1.globo.com/rn/rio-grande-do-norte/noticia/2013/06/justicapotiguar-nao-vai-interferir-em-interdicao-da-br-101-nos-protestos.html>, 
Então eu acho que coincidiu, primeiro não ser uma coisa individual, não era uma pessoa querendo ser advogado popular, coincidiu um grupo. E aí fez surgir um projeto, né? Pra começar, porque o Escritório Popular teve essa visibilidade? Porque existiu. Antes não existia. Que eu saiba, que a gente saiba, e que nos contaram, não tinha um projeto parecido. Então, não tinha assessoria jurídica dessa demanda. Devia ser coisas, tipo, assessorias de mandatos que pegavam essas coisas, assim, tangencialmente. Mas um projeto voltado para isso, pra assessoria dessas questões coletivas, dessas questões de direito à cidade, dessas questões de movimentos sociais, não devia ter. Então eu acho que, naturalmente, quando existiu, se encontrou. Até pelo perfil das pessoas. Não sendo personalista de pessoas $x$ e $x$, mas por todo o perfil que a gente traçou aqui na conversa, existe um perfil quando se está no Escritório Popular, acaba coincidindo com esse perfil de serem, normalmente, pessoas que têm militância para além daquele projeto (...).

Por fim, mas não menos relevante, é imprescindível fazermos referência à questão da sustentabilidade e estrutura do EP. Foi com esse objetivo que elencamos a implementação do Centro de Referência em Direitos Humanos da UFRN (CRDH) como um marco para o projeto. O CRDH surgiu a partir de uma proposta da UFRN aprovada em edital da então Secretaria de Direitos Humanos da Presidência da República (SDH/PR), em 2011, quando deu início a suas atividades, e funciona como um Programa de extensão da universidade. Como consta em seu site, o Centro atua da seguinte forma:

O CRDH/UFRN é dividido em três núcleos de atuação que receberam nomes de três grandes militantes: Carlos Marighella; Nísia Floresta e José Datrino, mais conhecido como o Profeta Gentileza. Juntamente com grupos parceiros, os núcleos atuam na defesa dos direitos da comunidade LGBT, da População de Rua, dos usuários de serviços de saúde mental, bem como no combate a tortura, extermínio da juventude e a intolerância religiosa. O Centro funciona como uma ponte entre a comunidade e os demais órgãos institucionais, a partir do qual são implementadas ações que se voltam à garantia, defesa e promoção dos Direitos Humanos, bem como o acesso à justiça e o estímulo ao debate sobre cidadania, no intuito de influenciar positivamente na conquista dos direitos individuais e coletivos. Para tanto, o $\mathrm{CRDH}$ atua prestando serviços de atendimento jurídico, social e psicológico, capacitação em Direitos Humanos, mediação de conflitos, apoio e articulação de atores públicos e de movimentos sociais, bem como na produção de conhecimento sobre Direitos Humanos. Para a realização do nosso trabalho contamos com profissionais, estagiários e bolsistas das áreas do direito, da psicologia, do serviço social e de áreas correlatas das ciências humanas ${ }^{101}$.

Em setembro de 2012, Setembro/2012: a partir da avaliação de falta de rotina de trabalho e de orientação, necessidade de sistematizar e organizar as demandas e da oportunidade de compartilhar um espaço com um projeto com concepções próximas às do $\mathrm{EP}$, um dos advogados do $\mathrm{CRDH}$, que era também advogado do $\mathrm{EP}$, lançou uma

101 Disponível em < http://crdhufrn.wixsite.com/crdh-ufrn/sobre-o-crdhufrn>. 
proposta para que o EP aproveitasse a estrutura do $\mathrm{CRDH}$ - ou seja, o espaço físico com computadores e impressoras, advogados atuando com conflitos de direitos humanos, estagiários, transporte da UFRN, etc., para conferir uma nova dinâmica ao projeto.

A ideia era criar uma rotina fixa de trabalho, potencializar suas articulações e diálogo com o $\mathrm{CRDH}$ e ao mesmo tempo compartilhar de sua estrutura, tendo em vista que a perspectiva de atuação já era próxima (de priorizar casos com dimensão coletiva e de sujeitos historicamente oprimidos, por exemplo). Com isso, uma outra lacuna do EP poderia ser sanada, a de ausência de orientadores para extensionistas da graduação. Assim, foi aprovada a proposta de expediente de bolsistas (à época o EP contava com duas bolsas) em duas tardes por semana, com possibilidade de outras pessoas do projeto se somarem se houvesse oportunidade. Nas palavras de um integrante, por ocasião desse debate: "Seria uma espécie de prática jurídica popular". Foi a partir daí que o CRDH passou a - literalmente - abrigar o EP, que pôde usufruir de toda a sua estrutura física, de recursos humanos e de equipamentos. Nos anos de 2012 e 2013, a parceria foi fundamental para garantir um acompanhamento mais estruturado a casos como o da "Revolta do Busão" e da Copa, além do cotidiano de demandas referentes a acampamentos do MST.

É importante mencionarmos, nesse sentido, que o $\mathrm{CRDH}$ - que surgiu em 2011 como projeto de extensão da UFRN - tornou-se "guarda-chuva" de outros projetos já existentes nessa universidade. Isso porque desde sua concepção materializou o encontro interdisciplinar de projetos de extensão em direitos humanos, como foi o caso do Escritório Popular e do OBIJUV, cujos debates, eixos de atuação e extensionistas passaram a construir uma "via de mão dupla" com o Centro de Referência.

A partir do diálogo entre grupos extensionistas da UFRN e da UFERSA - como a interlocução do Escritório Popular e o Gedic, no âmbito da extensão de cursos de direito - e da relevante experiência em assessoria a movimentos sociais e conflitos de direitos humanos em Natal, também a partir de convênio com a SDH/PR foi criado o $\mathrm{CRDH}$ do Semiárido, como projeto de extensão da UFERSA, "que visa contribuir para o cenário de promoção dos Direitos Humanos no Semiárido Potiguar, através de atendimento jurídico e social e ações de educação em Direitos Humanos", conforme o site do Centro $^{102}$. Não abordaremos aqui os conflitos coletivos e eixos de atuação de ambos os Centros de Referência, por não serem o tema deste trabalho, mas consideramos

$102 \begin{gathered}\text { Para mais informações, } \underset{\text { s }}{\mathrm{O}} \text { site do } \\ \text { <http://crdhsemiarido.blogspot.com.br/p/quem-somos.html>. }\end{gathered}$


pertinente mencionar a existência dos Centros porque nascem a partir da extensão universitária em direitos humanos e se constituem como pontes entre a universidade e conflitos sociais do estado, como analisa E4:

Tem uma confluência, de certa maneira; você tem uma criação do CRDH daqui e você tem o CRDH da UFERSA, em Mossoró; você tem a criação de um grupo de estudos lá que se propõe a fazer uma assessoria também e que bebe da mesma fonte e que surge, indiscutivelmente, por causa desse diálogo; são amigos, são pessoas que, fora disso, sentaram um momento e pensaram: 'poxa, é possível trazer uma...um projeto pra cá também'. E é um lugar que só tem um defensor público também, federal, entende? O recorte é absurdo. Então você tem portas sendo abertas, por causa disso, você tem profissionais sendo criados com outro perfil e esses profissionais estão indo pra outras instituições e eles tão passando a discutir ali dentro algumas conquistas. (E4)

A análise documental sobre a práxis do EP, bem como as falas das entrevistas, revelaram que os desafios de sustentabilidade por que passou o $\mathrm{CRDH} / \mathrm{UFRN}$ a partir de 2014 , com períodos de atraso do repasse dos recursos do convênio da SDH com a UFRN ou com a iminência de sua não renovação, impactou também a atuação do EP. Isso porque a estrutura - já mencionada - proporcionada pelo $\mathrm{CRDH}$ ao EP foi central para garantir uma rotina de atuação (com a presença de advogado e de estagiários/bolsistas), com possibilidade de deslocamento para além do município (casos do MST, por exemplo) e ter uma referência de espaço físico para reuniões internas, mas também para os movimentos assessorados, como explica E2:

[...] porque antes a gente fazia as reuniões até no C. A. de Direito ${ }^{103}$. As peças em casa, nos computadores pessoais. Hoje ele [o EP] funciona na estrutura do Centro de Referência em Direitos Humanos. Quando a gente tinha bolsa era show porque tinha bolsista. Então, assim, além dos estagiários do CRDH a gente tinha dois bolsistas que faziam as peças, então, se os estagiários do $\mathrm{CRDH}$ tivessem de boa tinham uns cinco estudantes para fazer as peças, era show. E a gente tinha dinheiro ainda para visitar. Visitar comunidade, protocolar quando tinha alguma coisa urgente e ir para as audiências, audiência de justificação prévia. E hoje ele é isso, hoje ele essencialmente assessora o MST. As reintegrações de posse. É uma das poucas coisas que funciona. A gente fez muita ação, a gente fez muita ação de indenização contra o Estado, mas que precisam ser protocoladas ainda, na época da Revolta do Busão. Inclusive tá até pra prescrever essas ações, tem que entrar agora, esse mês. Mas por que a gente não entrou antes? Porque o CRDH parou. E aí é isso que eu quis dizer, assim, hoje o Escritório Popular tá dependendo muito do CRDH. Por quê? Porque os meninos do Motyrum perderam os editais ou fizeram, enfim, não ganharam os recursos que eles estavam acostumados, então os bolsistas é que tocavam. E aí a gente conseguia um ou outro estudante voluntário que fazia as peças: [...]. Aí foi uma das coisas que a gente sempre dizia, assim, que o Escritório precisava de um local fixo pra gente

${ }^{103}$ A sala do Centro Acadêmico Amaro Cavalcanti (UFRN) era utilizada pelos projetos de extensão, inclusive pelo EP, para reuniões. 
orientar, fizesse as ações e tudo. Hoje ele é essencialmente isso. Não que ele não faça outras coisas, entendeu? Mas o Escritório Popular funciona plenamente quando tem os prazos do MST, dos acampamentos do MST, prazos de reintegração de posse. E audiência de justificação prévia, os advogados fazem a audiência. Então, assim, [...] o CRDH, então, pra mim ele é um projeto, o CRDH é um guarda-chuva de projetos. Hoje tem o projeto da Pop Rua, tem o projeto do Escritório Popular, que funcionam lá, que eu digo, funcionam lá, entendeu? E, não, por enquanto só tem esses dois. Eu não estou lembrando agora se tem outro, mas assim funciona esses projetos no guarda-chuva do CRDH. E a ideia é que o $\mathrm{CRDH}$ seja esse guarda-chuva de outros projetos, entende? Projetos de extensão em direitos humanos. $\mathrm{E}$ aí o $\mathrm{CRDH}$ ficou como referência também teve uma coisa: quando a gente... a gente fez umas atividades em acampamentos, o $\mathrm{CRDH}$, de educação. De saber quais as maiores demandas. $\mathrm{E}$ aí se tornou uma referência. Ali principalmente para esse Polo do Mato Grande, pra esse polo perto de Ceará-Mirim e um pouquinho mais acima. Então, Itaipu, eles têm uma referência na gente porque a gente fez essas ações. Então a brigada lá tem a referência já nos advogados [...] E sabem, eles vão pro $\mathrm{CRDH}$, entendeu? Eles têm um canto pra ir. (E2, grifo nosso)

Nesse mesmo sentido, ao falar sobre a parceria do CRDH com o EP, E3 demonstra como a falta de recursos no âmbito do Lições de Cidadania/Motyrum foi também determinante para que o EP passasse a se tornar mais orgânico ao Centro de

Referência que ao próprio programa (Lições) em que estava formalmente situado:

A gente inseriu o Escritório Popular no $\mathrm{CRDH}$, e eu acho que eu não falei isso em nenhum momento ainda, não sei se vai ter um momento pra explicar isso melhor.[...] Final de 2011. Com o projeto do $\mathrm{CRDH}$, tinha uma estrutura: tinha dois advogados, na época... Hoje são dois advogados. [...] E sempre tinha dois bolsistas de direito. Só que aí tinha várias demandas que a gente queria se inserir enquanto $\mathrm{CRDH}$, aí já falando como sujeito de outro espaço. Por exemplo, a questão da copa... mas que era uma coisa muito grande pra só dois estagiários do $\mathrm{CRDH}$ darem conta. Por outro lado, eu acho que talvez coincidiu de quando o Motyrum, Lições, nem lembro como era na época, ficou sem estrutura, perdeu, não conseguiu edital, então acho que dificultou. Enfim, não estava... a gente acabou inserindo. Pensei em uma coisa agora. Também coincidiu com a gente estar começando a trabalhar e não ter o mesmo tempo para se dedicar. $E$, no caso, a advogada, na época, o advogado hoje, que estava no Escritório Popular e que era do $\mathrm{CRDH}$, era quem tinha mais chances de encaminhar aquela demanda, né? Por questões profissionais, todo mundo lotado de coisa, "fudido", então foi por isso também a estratégia de colocar o Escritório Popular para funcionar no $\mathrm{CRDH}$. Porque fora dele a gente não tinha condições de dar o tempo que a gente dava antes: de reunião, de orientação e tudo. Então, foram esses vários fatores pra gente fazer as reuniões do Escritório Popular no $\mathrm{CRDH}$, né? Porque ali ia ter sempre uma advogada - hoje, um advogado - que fazia parte também do Escritório Popular, então que ia estar disponível pra orientar, pra tirar dúvida, pra demandar. Acho que foi uma das principais coisas pro Escritório Popular ir pra lá: pra gente ter pernas de tocar mesmo. E aí, hoje, acaba que a gente demanda pra fazer prazo, manda o modelo e a gente corrige e protocola. Se há alguma divisão de trabalho, hoje, talvez seja essa: a gente tenta que eles produzam as peças, os bolsistas, e a gente [advogados] corrige. (E3)

Esse deslocamento do EP - cujo programa de extensão de referência passou a ser o CRDH e menos o Motyrum - se refletiu também na composição do projeto, 
bem como em suas demandas. Se em sua origem o EP pretendia atuar principalmente com questões coletivas das comunidades assessoradas pelos outros núcleos do Lições de Cidadania/Motyrum, em sua caminhada o caminho foi se transformando e a agenda de casos do EP passou a ser pautada majoritariamente por movimentos sociais e por articulações em conjunto com o $\mathrm{CRDH}$ :

E lembrei de outro aspecto: o distanciamento do Escritório Popular em
relação aos outros núcleos do Motyrum. A ponto de a gente cogitar colocar
em pauta se [o Motyrum] é onde a gente deve estar. Porque quando a gente
demandava que os núcleos destacassem bolsistas para acompanhar o
Escritório Popular, especialmente os núcleos que tinham demanda, os
núcleos não faziam isso. E, por outro lado, a gente pegava demanda de
todos os cantos do Estado, menos dos núcleos. Estava atuando de forma
completamente independente, e o vínculo estava sendo mais a forma de
entrada. Que a gente, depois da experiência que teve, de forma de entrada
direto no Escritório Popular, que a gente avaliou com as próprias pessoas
que entraram [...], que não tinha sido bom, eles mesmo demandaram,
sentiram falta de estar no núcleo, até hoje a gente continua selecionando
dentro do Motyrum, quando faz seleção. Então esse vínculo ainda existe.
Se bem que, como hoje tá mais com os estagiários do CRDH, então acaba
que tá entrando por fora do Motyrum porque os estagiários do CRDH tão se
agregando. Mas a gente nunca abriu seleção pra entrar direto. Por mais que
o Motyrum esteja passando por essas dificuldades, a gente ainda estava
acreditando que a formação que ele dava era um pré-requisito importante
pra não chegar no Escritório Popular, por eu já ter explicado que eu acho
que a atuação é mais de advocacia, e não é interdisciplinar, e que ele não ia
ter as vivências que a gente acha que um estudante de direito deve ter, só
no Escritório.(E3)

E3 faz referência à forma de ingresso no EP como um dos únicos vínculos de organicidade do projeto com o Motyrum. Essa menção diz respeito ao critério para ser extensionista do EP e ao processo de seleção para a entrada de novas integrantes. Como apresentamos no capítulo 1, o método de entrada de novas extensionistas no Lições e, posteriormente, no Motyrum, é um processo de "formação-seleção", em que as pessoas interessadas em integrar o programa de extensão participam de encontros semanais com metodologias e temas próprios dos núcleos e da educação popular em direitos humanos (a programação é previamente divulgada). Ao final, as novas extensionistas devem escolher qual núcleo desejam integrar. Assim, o critério para fazer parte do EP era único: já ter integrado ou integrar algum dos núcleos de educação popular em direitos humanos do Motyrum. Essa exigência foi fruto de debate interno no EP e da compreensão de que para participar de seu cotidiano de assessoria jurídica era fundamental vivenciar um 
processo com os sujeitos oprimidos de outra forma, que não a pautada por prazos processuais e dinâmicas demandadas pelo sistema de justiça.

Devido à visibilidade que o EP adquiriu por sua atuação em casos emblemáticos de Natal, entre 2011 e 2012 cresceu a procura de pessoas interessadas em integrar o projeto. Para não perder a oportunidade de agregar novas extensionistas à práxis da assessoria jurídica popular, o critério que exigia participação anterior em outro núcleo foi reformulado, tendo sido permitida a entrada diretamente no EP, a partir da formação-seleção do Lições. Dessa forma, ingressaram três extensionistas da graduação em direito que jamais haviam vivenciado processos de educação popular. Entretanto, como mencionou E3, a avaliação dessa mudança do critério não foi positiva, tendo em vista que as novas integrantes sentiram falta do contato prévio com as comunidades e sujeitos - a ponto de procurar os outros núcleos após sua entrada no EP e demandar que não fosse possível a entrada diretamente no projeto.

Assim, salvo essa experiência inicial, o método de entrada foi sempre via formação-seleção do Motyrum, com a exigência de participação anterior ou simultânea em algum dos núcleos de educação popular. Até 2015. Em 2015, houve novo debate interno sobre essa questão, e as extensionistas do EP decidiram reformular o critério de entrada: decidiram realizar um processo próprio de ingresso no projeto, independente da formação-seleção do Motyrum (pela primeira vez na história do EP) e não mais exigiriam a participação anterior no programa.

Em relação às integrantes do EP, importa destacar também que o projeto conta, desde 2011, com advogadas e advogados atuantes e que decidiram seus projetos de vida na advocacia popular a partir de sua atuação no EP ainda durante a graduação. 


\title{
CAPÍTULO 3 POR UMA PEDAGOGIA DA JUSTIÇA: A FUNÇÃO DEMOCRATIZANTE DO ESCRITÓRIO POPULAR
}

\begin{abstract}
E: Você acha que o Escritório Popular desempenha alguma função para a justiça?

E2: Fazer raiva (risos de E2). Eu acho que a gente faz um bom... uma contra hegemonia. Acho que a gente é um dos poucos grupos organizados. Eu acho que tem muitos advogados que faziam isso... Daniel ${ }^{104}$, eu acho que dava muita raiva, sozinho. Mas acho que quando se organizou, minimamente, eu acho que aí conseguiu organizar uma resistência. Não vou nem dizer ofensiva. Uma resistência. (Entrevista 2, grifos nossos).
\end{abstract}

A hipótese que norteou nossa pesquisa foi a de que o Escritório Popular (EP) se constitui, a partir de seu quefazer, como um ator para a democratização da justiça no RN. Ao analisarmos sua trajetória e ouvirmos seus sujeitos, nossa compreensão é a de que a principal contribuição democratizante do projeto é sua dimensão pedagógica. Neste capítulo desenvolveremos essa dimensão pedagógica para a justiça a partir da práxis do EP. Para tanto, privilegiaremos as percepções das e dos extensionistas sobre os significados atribuídos ao direito, aos direitos humanos e ao acesso à justiça, para, então, refletirmos teoricamente sobre referidas concepções. Essa reflexão atenderá o terceiro objetivo específico que estabelecemos na pesquisa acadêmica, que é investigar as concepções de direito e de direitos humanos que balizam a atuação do EP.

Consideramos que o fator determinante para a democratização da justiça no contexto investigado (do EP) tem sido menos o "quefazer" e mais os sujeitos em luta ou o bem pelo qual se luta. Assim, na centralidade daquilo que identificamos como sendo uma função democratizante da justiça desempenhada pelo EP está a aliança com os sujeitos coletivos de direito com os quais atua. É essa aliança política, esse compromisso engajado com a transformação social da realidade, firmada em diálogo e com os movimentos sociais, com o povo, que caracteriza e distingue o EP como ator para a democratização da justiça cujo principal fator é a sua dimensão pedagógica.

É emblemática a indicação por E7 da existência de uma "sensibilidade" na atuação dos processos desenvolvidos pelo EP:

\footnotetext{
104 Referência a Daniel Alves Pessoa, advogado popular que à época do surgimento do projeto era um dos únicos advogados articulados na RENAP no RN, atuando, geralmente, sozinho no estado. Além dele, havia apenas Luciano Falcão e Daniel Valença, este último atuando como professor universitário.
} 
[...] quando você atua tendo dimensão do que é aquele conflito, do que representa aquele conflito, em termos macro, [...] entende a disputa que tá posta ali... entende a relação do acampado com o latifúndio, com a terra, com o Estado, com a violência que o Estado comete ao fazer as reintegrações e tal.... você consegue ter, digamos assim, uma sensibilidade. O que eu sinto é isso: uma sensibilidade diferente pra conduzir o processo. E aí conduzir o processo não só o processo judicial, mas todo o processo de negociações que às vezes se desencadeiam, de quando ocorre uma ocupação, uma obstrução de BR em razão de uma reintegração de posse que tá pra ser cumprida, entendeu? Então eu acho que faz diferença, a gente consegue fazer diferença no diálogo com as autoridades policiais porque a gente tá empoderado da importância daquele conflito, da dimensão que ele tem. Eu acho que, assim, você consegue tá convencido, o fato de você tá convencido da necessidade de ocupar, da importância daquela luta, faz com que você consiga conduzir melhor uma audiência. Tenha a sensibilidade de entender aquela realidade porque a gente não só conhece a técnica sobre a posse velha e a posse nova e porque não deve ser reintegrado porque a posse já é velha, entendeu? A gente conhece a realidade daquele acampamento, a gente conhece a realidade da luta pela Reforma Agrária e com esses elementos eu acho que a gente consegue dialogar melhor com o juiz na audiência. Acho que a gente consegue dialogar melhor com o próprio, a gente consegue, por exemplo, "colocar em situações" o advogado do latifundiário e o próprio latifundiário em audiência. Consegue colocar eles em situações de saia justa, que um advogado totalmente alheio aquela realidade talvez não conseguiria. Não estou dizendo que não conseguiria. Eu acredito que não conseguiria, entendeu? É assim, o que eu sinto é que faz a diferença você conhecer a fundo o porquê daquele conflito ter se instaurado. De onde vem a ocupação, qual a legitimidade dela, qual é a importância dela para a macropolítica, para além daquele conflito específico, daquele processo judicial específico. (E7, grifos nossos)

Quando analisamos a constituição do EP e observamos alguns de seus casos, identificamos a adoção de um conjunto de estratégias não estritamente jurídicas que acaba por desvelar a atuação do sistema de justiça e, com maior destaque, do Judiciário, como um ator em aliança com os interesses econômicos e do capital. Nesse sentido, é pedagógico o "estalo" (ALMEIDA, 2015) promovido pelo EP com a leitura do sistema de justiça, assim como é transformador a ponto de definir projetos de vida, através do contato com a realidade dos sujeitos e os processos de bloqueio de acesso à justiça que enfrentam. É, ainda, o processo de compreensão de que o horizonte do jurista não é restrito a buscar direito - não um direito dogmático, não o direito positivado, mas justiça. Independente de que sigam como advogadas e advogados populares, é uma experiência de encharcamento de realidade que desloca percepções, olhares, referências:

E aí você não tem contato com aquele sujeito, e eu acho que o Escritório Popular preza. Isso é, praticamente regra, assim, ter contato com os sujeitos, sabe? Isso faz muita diferença na elaboração de uma peça. Em quem... não sei se no resultado, mas no envolvimento que você tem com aquilo ali. Acho que envolvimento, eu acho que pode ser uma palavra a se falar nessa diferença. Os defensores ficam nos seus gabinetes, ou enfim, tem outras audiências para participar e o estagiário fica ali. Então senti muita falta disso na defensoria. Eu acho que envolvimento ele te encharca de realidade, ele te motiva. Eu acho que é isso, te motiva(E5) 
Essa ideia de deslocamento guarda relação com a noção de desvelamento do mundo trabalhada por Paulo Freire (2012) e também com relevantes reflexões e denúncias propostas pela teoria crítica em direito (LYRA, 1980, 1984 e 2003; SOUSA JUNIOR, 2011; AGUIAR, 1990 e 1995) e em direitos humanos (HERRERA FLORES, 2009a e 2099b; GALLARDO, 2014), no sentido de romper com a perspectiva hegemônica sobre o que são direitos e direitos humanos e abrir possibilidades para uma conscientização rumo à libertação, rumo a uma compreensão de direito que incorpora e parte de uma dimensão de luta popular.

E de que forma a experiência do EP o constitui como um ator para a democratização da justiça?

Inicialmente, destacamos que nossa análise é de que o EP age de forma a desvelar o Judiciário como um ator cujo padrão de atuação é o de bloqueio das lutas políticas dos sujeitos oprimidos. Essa atuação é, por si só, um aspecto democratizante, pois não é esse o cenário tradicionalmente visto na educação jurídica convencional. Não é essa a experiência experimentada pelas e pelos estudantes dos cursos de direito no Brasil. Não é esse o perfil do Judiciário que é apresentado no ensino jurídico hegemônico e nem que é ofertado pela maior parte dos estágios. Inspirados em Paulo Freire (2012), compreendemos que o desvelamento do Judiciário é um movimento possível dentro das perspectivas necessárias ao desvelamento do mundo, e o EP viabiliza uma leitura de mundo ou, na verdade, leitura do Judiciário nos permitimos fazer aqui uma analogia com a categoria freireana - que, por si só, é um elemento democratizante.

Remetendo ao trabalho de Paulo Freire com as categorias "denúncia" e "anúncio", refletimos que a atuação do EP com sujeitos oprimidos no campo de batalha do Judiciário é uma ferramenta de denúncia de situações de opressão e exclusão social, assim como denuncia o cenário de cerceamentos de direitos, de criminalização, de bloqueio de acesso à justiça e de lutas políticas. Cenário este que, ainda, conta com o alinhamento do sistema de justiça com as forças econômicas hegemônicas, de que são exemplos o latifúndio e os projetos de desenvolvimento de retrocessos de direitos, entre outros.

A denúncia, a nosso ver, é igualmente um indicativo de uma função democratizante da justiça. Isso porque ela é um ato que rompe com a visão idealizada, fetichizada e alienante de Judiciário, cuja característica maior traçada pela perspectiva hegemônica liberal é a neutralidade, qualidade esta que, como um mito, é 
ensinada nas disciplinas dogmáticas do curso de direito, constituindo um verdadeiro padrão hegemônico da educação jurídica brasileira.

A pedagogia do EP tem a ensinar inclusive ao sistema de justiça e ao "governo do Judiciário" (ESCRIVÃO FILHO, 2015, p.33), na medida em que ele próprio se constitui como ator do sistema de justiça. Isso porque, nos casos em que atua, exerce um papel de agente da advocacia popular, que carrega consigo uma cultura jurídica diferenciada em relação ao padrão hegemônico do Judiciário. A atuação do EP caracteriza-se pelo rompimento com a "cultura do silêncio" (LIMA, 2015), justamente por conseguir estabelecer uma relação de dialogicidade com os sujeitos sem-direitos com os quais atua. À essas características, somam-se outras reveladoras de uma nova pedagogia da justiça, dentre as quais identificamos, com destaque, o contato direto que promove com sua realidade social, as relações internas de horizontalidade que estabelece enquanto projeto de extensão, o diálogo de saberes que adota como referência para atuação, e a utilização de concepções diferenciadas de direito e de direitos humanos, sendo estes produto das lutas e materialização de justiça, e, aquele, expressão de luta.

No EP há uma via de mão-dupla de diálogo permanente entre a forma de organização interna e as concepções do projeto com suas intervenções externas com os sujeitos sem-direitos, com o sistema de justiça e com a universidade, que revela uma compreensão de democratização da justiça mais ampla que a inclusão de determinados sujeitos no âmbito do Judiciário:

\footnotetext{
Porque eu acho que ela pode ser dado como exemplo porque quando a gente fala de democratização da justiça, no Fora Micarla, eu não consigo ver só o viés judicial, né? A gente tava ali em diálogo com várias instituições políticas e isso, esse debate não foi só dentro do gabinete, né? Ele mobilizou toda uma cidade, mobilizou todo um conjunto de pessoas e meio que... A insatisfação das pessoas não ficou só nas reclamações, de um que faz com outro, sei lá, na parada de ônibus, né? Que absurdo esse transporte, que absurdo essa educação, que absurdo essa gestão. Mas foi uma voz que, para mim, foi uma verdade democracia, né? O Fora Micarla, no movimento como um todo, e ai, o Escritório Popular ter sido um dos protagonistas, né? Enfim, eu me arrepio só de pensar, porque aquele momento que tava todo mundo já preparado pra levar cacete, de repente chega a galera, tipo assim, a cavalaria tá chegando, a PM tá chegando e de repente, chega a galera dizendo que chegou no STJ com aquela decisão, e aquilo ali como... Assim, sem ter uma visão muito romântica do direito, mas aquilo ali salvou a vida de muita gente. Salvou dente, salvou pele, salvou vida de muita gente. Mas assim, lógico, o Escritório Popular não foi só a ação, né? Foi também tá ali conversando com a Câmara, conversando, em diálogo com a OAB, enfim, mas aquele processo que o Escritório Popular fez parte foi... Foi um amadurecimento, foi uma experiência de amadurecimento de democracia muito grande, né? Não só política, mas de justiça também de certa forma, né? A gente tava ali reivindicando o direito de manifestação. (E5, grifo nosso)
} 
Para identificarmos as concepções do e no projeto de extensão estudado, incluímos três perguntas no roteiro elaborado para as entrevistas semiestruturadas (conferir ANEXO B): se o EP possui alguma/s concepção de direito que norteia a sua atuação; se o EP possui alguma/s concepção de direitos humanos que norteia a sua atuação; e qual é a relação entre essas concepções e a visão de direito e de direitos humanos da sua formação (curricular) na graduação. Selecionamos algumas respostas dadas pelas e pelos extensionistas entrevistadas e entrevistados com 0 objetivo de privilegiar suas falas e vozes e em diálogo com suas percepções refletirmos teoricamente sobre o tema.

\subsection{A dimensão pedagógica como função democratizante}

Escolhemos iniciar a discussão proposta ao capítulo 3 abordando a dimensão pedagógica do EP. A justificativa é tanto porque o Escritório Popular se constitui como prática educativa emancipadora - porque é um projeto de extensão universitária, está localizado na universidade, em um programa de educação em direitos, com uma perspectiva crítica de atuar junto a sujeitos oprimidos -, como porque a sua dimensão pedagógica é também materialização de sua função democratizante. Isto é, sua dimensão pedagógica por si só exerce uma função democratizante, ela é reflexo de um processo de democratização da justiça a partir da práxis do projeto.

O Motyrum, conforme abordamos nos capítulos 1 e 2 dessa dissertação, está localizando na área temática de Direitos humanos e Justiça da Pró-Reitoria de Extensão da UFRN, tendo sido um dos primeiros programas dessa área na universidade.

Sabemos que, dentre inúmeros instrumentos historicamente utilizados para a manutenção do status quo, ou seja, para assegurar que as classes e grupos dominantes continuarão como tais e que as classes e grupos historicamente dominados, subalternizados, oprimidos, continuarão nessa condição, temos a Universidade e o Direito. A Universidade porque, como já debatido pelas teorias críticas da educação, a educação tem sido um dos grandes mecanismos de reprodução de valores, de conhecimentos e de relações sociais (MÉSZÁROS, 2008). É usada para ensinar o lugar de cada um na estrutural social (SAVIANI \& DUARTE, 2012). A perspectiva neoliberal vem com a dose de apatia e de fatalismo de fazer-nos acreditar que a realidade é tal como está dada hoje, não sendo possível transformá-la. 
A Universidade serve para reproduzir esses valores e para formar as pessoas que ocuparão as grandes funções do Estado, nos seus três Poderes, em geral. Essa manutenção do status quo já era trazida por teóricos como Althusser (1985), em suas formulações sobre os aparelhos ideológicos do Estado. Mais recentemente, autores críticos como Tonet (2012) e Mészáros (2008) aprofundam essa discussão e dão destaque para a necessidade de pensarmos em alternativas para a educação diante dos limites do sistema capitalista. Por sua vez, o Direito, porque é usado para legitimar as relações de dominação na sociedade. O aparato jurídico e o sistema de justiça funcionam claramente para servir a determinados interesses do capital e das classes dominantes (LYRA FILHO, 2003): serve a sujeitos específicos, a grupos específicos, a valores específicos, tendo como pano de fundo garantir a perpetuação das desigualdades e do status quo.

Não são o povo e os grupos historicamente oprimidos os que estão ocupando os lugares da Universidade brasileira, tampouco os espaços do Direito - até porque, para estar nesses últimos, precisa ter passado por aqueles, e o Direito hegemônico, positivado, só reconhece como Direito o produzido pelo Estado, aparece como forma de controle social (LYRA FILHO, 2003). Nesse sentido, o curso de Direito revela-se um espaço altamente elitizado e alienador, conforme analisa o entrevistado 3 :

[...] se o curso de direito já tem o filtro de classe na própria entrada, especialmente na Universidade Pública, acaba significando que são pessoas distantes da realidade da maioria da população, são pessoas que tem oportunidades que maioria da população não tem, já começa o filtro antes, quando chega no curso não é reforçado, por exemplo, a Extensão. Não é reforçado você conhecer a comunidade, é reforçado você estudar pra tirar notas boas e você produzir artigos pra, enfim, seu Lattes. Então, esse distanciamento da realidade é reforçado, se já teve no filtro do acesso, é reforçado nessa subvalorização da Extensão e nessa patética permissão de que evento, palestra, sejam projetos de Extensão. Que vai contra o Estatuto da UFRN, inclusive, eu e Hélio já escrevemos um artigo sobre isso. E aí, enfim, depois de se formar, de estudar pra concurso público, pronto, é a cristalização da "bolha". O que vinha no processo de "faço direito, não preciso conhecer a realidade, não preciso pisar no chão" se cristaliza aí no... Eu acho que até no curso de medicina, as pessoas tem mais acesso às comunidades, às populações vulneráveis, do que o curso de direito. Você só tem acesso a esse tipo de realidade, no curso de direito, se for absolutamente por iniciativa própria sua, não tem nada que the vincule, nada que... A prática jurídica é na Universidade, não tem nada que faça que você se forme tendo que ter passado, alguma vez, por uma comunidade vulnerável. Até medicina tem, por causa das, sei lá como chama, das residências lá, e direito não tem. $E$ aí isso vai seguir, depois, na forma de seleção pra concurso público que a gente ouviu de um - acho que tu estava nessa - juiz, era um juiz? Que saiu de casa e alugou um kit net pra se isolar até da família e estudar dezoito horas por dia sem ter nem, nada, nada ... Ou seja, se alienar totalmente da realidade onde vive. Mas isso é só a cristalização de um processo que começa antes. (E3). 
Assim, a experiência do Escritório Popular do Motyrum da UFRN, um projeto de extensão universitária, traz uma possibilidade de se colocar como ferramenta contra hegemônica em relação ao uso desses dois instrumentos, nessas duas dimensões, da Universidade e do Direito, sobretudo por causa de um elemento central: a escolha dos sujeitos com quem atua. Segundo E1:

\section{[...] o Escritório Popular é um núcleo, que eu definiria como um núcleo instrumentalizador. Um núcleo que instrumentaliza as demandas e necessidades, instrumentaliza judicialmente as demandas e necessidades que surgem no decorrer das atividades nos demais núcleos. Eu daria essa característica de instrumentalização das demandas e politização dessas demandas no Poder Judiciário. Eu daria essa definição pro Núcleo, que se volta como instrumento de politização daquelas demandas dentro do Poder Judiciário (E1, grifos nossos).}

Sua atuação seria qualificada pelo fato de voltar-se a um processo de politização decorrente dos conflitos que lhes são apresentados pelos sujeitos com os quais atua. Nesse sentido, o EP desempenharia a função de instrumento para politização de demandas no Judiciário.

Complementando, E7 apresenta alguns elementos importantes para a caracterização da atuação do projeto a partir dos sujeitos com os quais atua: a estreita relação estabelecida entre a existência do EP e a necessidade de atuação jurídica para impedir processos de criminalização de movimentos sociais; a possibilidade de viabilizar a judicialização de determinados problemas no contexto potiguar; e a potencialidade de atuar na política do Estado, em sentido amplo.

Eu acho que a importância dele existir, eu acho que ele existe pra atender a demanda forte que existe de criminalização dos movimentos sociais, como um todo. E aí a gente observa que ele surgiu num contexto específico de atender a demanda de judicialização de problemas, muitas vezes relacionado a políticas públicas, de um Programa de Extensão. E aí ele se ampliou na práxis foi que a gente identificou a necessidade de atuação mais geral no âmbito dos movimentos sociais e da política como um todo de Natal e do estado. E, assim, primeiro ele existe pra atender aos sujeitos que não são atendidos por ninguém juridicamente. Porque, assim, o que a gente observa é que a gente criou de 2011 pra cá, a gente criou muitas parcerias, seja com a OAB, seja com a universidade através do CRDH's, seja com mandatos de parlamentares de esquerda e em nenhum momento, e nunca houve a, nunca se pegou essa tarefa pra nenhum desses atores. Essa tarefa de defesa dos movimentos sociais ela tá concentrada hoje no Escritório Popular ainda e no CRDH. E aí é o que eu enfatizo sempre porque o CRDH/UFRN, o da UFERSA eu não conheço, não posso falar, mas o CRDH da UFRN ele tem essa mesma concepção na atuação jurídica, mas muito influenciado pelo próprio Escritório Popular. Não é à toa, tanto os sujeitos que compõe quanto a própria concepção de como ele foi pensado, a concepção do Escritório Popular estava lá. (E7) 
A partir do momento em que esse projeto escolhe por atuar com os sujeitos do povo, compreendendo que os protagonistas dos processos de transformação social são esses sujeitos, que eles são os sujeitos revolucionários, e se deixando instrumentalizar para essas lutas, o EP colabora diretamente para a transformação dos processos da Universidade e do Direito, para sua democratização.

As entrevistas revelaram uma dimensão muito específica da democratização da justiça a partir da experiência do EP: a democratização no processo de elaboração das teses jurídicas e das estratégias para defender direitos e reivindicar justiça. Rompendo com um padrão tradicional de atuação jurídica que enxerga a assessoria jurídica como atividade única e exclusiva de determinados sujeitos para os quais é conferida a capacidade postulatória, o EP não reivindica autoridade ou legitimidade exclusiva para a resolução de conflitos. Antes, abre-se ao diálogo e constrói sua atuação com e a partir dos sujeitos com os quais atua. É o que explica E4:

\begin{abstract}
Então o Escritório Popular, ele é um desafio à sua criatividade nesse sentido. Você tá em contato com outras pessoas que estão pensando juntos a resolução daquele problema; e a resolução do problema é...parece ser muito audacioso, né...porque você não vai resolver o problema juridicamente, judicialmente ali, mas aquele ponto, aquele processo, aquela demanda tá com você e não tá só com você, tá com várias pessoas e aí você pode perguntar 'e como fazer isso?' e 'por que?' e como é que a gente pode usar os instrumentos judiciais? E nisso você tem uma ventilação de teses e de ideias, que é desafiadora e que the permite ir além pra sua formação pessoal, profissional... Até hoje eu sinto muita autonomia daquele momento, que eu aprendi naquele momento, de ter sentido a possibilidade de perguntar e de ter alguém que tá junto com você para the auxiliar nisso porque os dois querem a mesma solução; os dois, os três, os cinco, os 10 que tão ali com você. Então a dinâmica já é distinta nesse ponto... Você tem judicialmente o trabalho coletivo, você tem um trabalho em que o advogado, ele também se encontra numa situação de humildade e de honestidade; que ele recém-formado num tinha um espaço muito maior de experiência que você e que ele vai dizer que não sabe fazer, mas que ele vai pesquisar e ele vai buscar resposta pra você, mas ele não tá se colocando como seu guru intelectual, ele não tá se colocando como alguém superior a você. Isso the permite uma situação franca de sinceridade e de perguntar coisas que, inclusive, poderiam ser tolas, que você não sabia, que outra pessoa pode achar óbvia, mas que ali você não tem problema, você pode ventilar aquilo. Então aquela horizontalidade, aquele trabalho em conjunto, ele dá uma dinâmica distinta, porém, ele não se dissocia de outras questões... Que são as políticas, sociais e também midiáticas, eu acho; lógico, tudo seria social, mas você entende que tem estratégias judiciais que elas não são politicamente hábeis e esse é um viés que você só pega ali naquela experiência do dia-dia e que você aprende com os movimentos sociais, os movimentos sociais vão dizer a você. Você não tem essa experiência de vida, você não tem compreensão. (E4, grifos nossos).
\end{abstract}

É apenas um projeto de extensão, porém, que coloca em xeque o paradigma dominante do direito, na medida em que provoca deslocamentos no direito - dimensão 
coletiva, produção de direito a partir das lutas, humanização dos processos, dos espaços do direito e de quem atua no âmbito do sistema de justiça. E rompe com o paradigma dominante de Universidade por meio da extensão popular - relações horizontais, criatividade, construções coletivas, conhecimento implicado com a realidade social e produzido a partir dela.

\begin{abstract}
Eu sempre apresento o Escritório Popular em texto, diante das pessoas, eu digo que é um projeto de extensão que tem como base a assessoria jurídica popular, no caso, assessoramento de movimentos sociais.. que tem como objetivo promover o acesso à justiça, a democratização do judiciário, desconstruir conceitos também dentro do judiciário, tipo o MST, a gente ta ali tentando desconstruir a visão proprietarista do poder judiciário. Se a gente ta ali defendendo a APAC, a gente ta querendo aproximar... ou o "Fora Mircala", a gente tá, de uma certa forma, provocando a aproximação do poder judiciário de uma realidade concreta, né? Então, eu acho que tem um pouco essa função de promover esse acesso à justiça, eu acho que ainda existe uma deficiência muito grande quanto ao acesso dos Movimentos Sociais, né? Esses obstáculos que a gente vê do básico que são as garantias processuais, eu acho que o Escritório Popular disputa isso. Ela disputa concepções conservadoras no direito, seja de propriedade, seja de Movimentos Sociais mesmo, seja de luta por direitos... da práxis políticas desses movimentos, das ocupações, das mobilizações na rua, né? Então, quando a gente entra, por exemplo, com uma ação para questionar a utilidade pública das obras de desapropriação aqui em Natal... cumpre meio esse papel, mesmo que... que o juiz, sei lá, nem leia aquelas 40 páginas que a gente fez de ação ordinária ou de MS mas que... meio que a gente tá questionando, né? De certa forma, mesmo que a gente não obtenha êxito, de certa forma, a gente tá escrevendo a história dentro desse círculo do judiciário, provocando questionamentos, quer dizer, por que não pode ser questionada a utilidade pública de um decreto de desapropriação? (E5, grifos nossos)
\end{abstract}

O EP contribui para democratizar a sociedade e a democracia. Democratiza, portanto, a Universidade, o Direito, o conhecimento e o perfil dos profissionais que passam pelo projeto.

$\mathrm{Na}$ medida em que a Universidade se coloca como estrutura de dominação, o projeto se contrapõe, resiste como uma possibilidade de prática emancipatória nesse cenário de uma estrutura de dominação e provoca a universidade, por sua práxis, a se pensar para quê e para quem ela existe (cf. RIBEIRO, 1982); provoca a extensão, ao disputar a concepção de extensão, questiona esse "não lugar" da extensão no curso de direito, no qual extensão vem sendo o que não é pesquisa e não é ensino; disputa e demarca, se contrapõe à hegemonia com uma concepção popular de extensão; materializa o princípio da indissociabilidade de ensino, pesquisa e extensão. 
Nesse sentido, E6 situa o EP em um contexto mais amplo de disputa do curso de direito:

\begin{abstract}
O Escritório Popular, eu acho que... Primeiro: é um projeto de disputa dentro do curso de direito... A princípio, né? Você discute uma concepção de direito que está ali, uma concepção de direitos humanos e de certa forma acaba formando profissionais de direito que tenham uma maior proximidade a movimentos sociais, então pra um curso que tem um perfil muito de classe média, muito de gente que saiu de escolas particulares - agora que mudou mais o perfil, mas, pelo menos na minha época era assim - tem um papel muito importante, de você colocar... De você aproximar estudantes a movimentos sociais e começar a modificar a concepção de mundo que essa pessoa, que esse povo tem, né? Que os estudantes têm. Mas ele também, o Escritório Popular também tem... Para os estudantes, tem esse papel e é importantíssimo porque você consegue levar esse... Sair da sala de aula pra ter uma compreensão mais do real, mais do que acontece de fato na sociedade. Mas eu acho também que tem uma dimensão muito importante pra os sujeitos que não são estudantes, os movimentos sociais, porque é um instrumento de suporte da luta. Porque há uma demanda real de técnicos do direito que permitam que a galera permaneça em luta, permaneçam em ocupações, ou impeçam grandes ações policiais, em atos, por exemplo, o que já foi atuação do Escritório. Tem essa dimensão de instrumento de suporte da luta, de permitir que se permita... Não tem nem que "permitir que se permita em luta", porque se não houvesse Escritório, a galera permaneceria em luta. Mas permitir uma outra trincheira de luta, um acesso à outra trincheira de luta que é no judiciário. (E6, grifos nossos)
\end{abstract}

Vale salientar, no entanto, que a democratização materializada nas práticas do Escritório Popular tem um limite interno que é imposto pelo próprio modo de funcionamento do capital e de suas instituições. Esse limite situa as práticas de extensão em um complexo campo de disputa de concepção e daí decorre o debate sobre a sua função social e o potencial que o EP carrega de resistência à concepção hegemônica de extensão. Nesse sentido, é elucidativa a oitava entrevista:

[...] o projeto, ele enquanto atividade acadêmica se enquadra perfeitamente como extensão. Me parece que é bem claro. Mas assim não inviabiliza, até porque por uma concepção que acho que é partilhada pelas pessoas que fazem o projeto lá na universidade, não inviabiliza a questão de ensino nem de pesquisa. Claro que o foco maior é a extensão, na perspectiva do papel institucional que têm que ter do contato e o que ela produz servir para sociedade. Isso é outra coisa muito interessante do projeto. Eu vejo como Assessoria Jurídica Popular da Universidade, mas num modelo que me parece diferenciado em relação a outras experiências como o NAJU/ $\mathrm{CAJU}^{1}$, que tem por aí. (E8)

A extensão universitária é situada, historicamente, em um lugar de saber no qual a dimensão pedagógica ocorre em uma via de mão dupla. Isto é, ao mesmo tempo em que tem o potencial de intervir na realidade social (seja para manutenção ou rompimento de valores e normas preestabelecidos), também contribui para a 
formação dos sujeitos (universitários) que estão fazendo determinada atuação, posto que estes se deparam com uma realidade com a qual não teriam contato se não fosse por meio da extensão universitária.

À primeira vista, essa dupla função se apresenta enquanto um aspecto positivo, especialmente no curso de Direito, que nos interessa. No entanto, ao analisarmos criticamente os elementos que subjazem essas experiências, vimos emergir algo revelador: se, por um lado, as práticas extensionistas em geral deveriam servir para fazer a universidade enxergar a realidade social e produzir a partir dela e com ela, construindo conhecimentos com o povo e para o povo; por outro, observamos que sua função social só se configura de tal maneira porque o povo não está na universidade. Isto é, a parede invisível que separa as instituições de produção de conhecimentos do restante da sociedade (de onde provêm as informações para produção de conhecimentos) produz a necessidade de um elo de ligação entre essas duas, e a extensão tem cumprido essa função.

Desta forma, percebemos o campo nebuloso no qual está localizada a extensão universitária que, ao que parece, tem conseguido romper os muros da universidade por uma só via: de fazer a universidade chegar ao povo, e não o inverso. No entanto, vale salientar que esse limite interno não é produto da forma de se fazer extensão em si, mas da macroestrutura social que localiza a universidade nesse lugar de segregação. Na verdade, ensino, pesquisa e extensão seguem indissociados na dimensão de seu alheamento à realidade social e de atuação em função da manutenção do status quo, não tratam dos temas, nem dos, nem com os sujeitos que deveriam tratar, então se contrapõe nessa medida em que constrói, a partir da extensão, ensino e pesquisa em diálogo com os sujeitos historicamente sem-direitos, dominados, a partir de suas demandas concretas, em relações horizontais, com 0 compromisso político de pensar os problemas sociais e a partir deles nos processos.

Por fim, o Escritório Popular aproxima-se da noção de assessoria jurídica universitária popular, que é uma experiência de extensão, cujos marcos são de atuação com educação em direitos humanos, com os sujeitos oprimidos, que são os sujeitos coletivos de direito, atuar com a perspectiva da advocacia popular, com essa dimensão política. Contudo, diferencia-se por seu "quefazer" que o coloca como ponte que rompe com concepção de ilhas isoladas e incomunicáveis de extensão e advocacia popular, constituindo-se como elemento de coesão entre ambos, de troca, de diálogo e de pertencimento a ambos os campos. 
Segundo E3, o EP constitui um instrumento a serviço dos movimentos sociais com os quais atua e, portanto, sua atuação é acessória, complementar e, consequentemente, não protagoniza os processos de luta.

\begin{abstract}
Outra concepção que eu tenho é que eu acho que nós somos acessórios. Nós não somos protagonistas dessas lutas dos movimentos que nós assessoramos. Nós somos uma pequena parte. Isso a gente faz sempre questão de, quando vai fazer uma fala pra explicar, uma decisão, principalmente quando a decisão é ruim [risos], essa clareza de que a luta existe independentemente do Escritório Popular. A luta existe independentemente dos processos correrem à revelia. Independentemente de alguém ir preso, de vez em quando; de ter despejo, de vez em quando, entendeu? (E3, grifos nossos).
\end{abstract}

Esse caráter de acessório, contudo, não significa que sua atuação é totalmente dispensável. Pelo contrário: a atuação acessória do EP em relação aos conflitos envolvendo movimentos sociais é percebida como emblemática para "facilitar" a luta por direitos e justiça. Ainda segundo E3:

[...] Mas nós somos um acessório que pode facilitar essa luta em alguns pontos, né. Pode evitar que uma liderança esteja presa ao invés de estar organizando. Pode evitar que um acampamento, que demorou muito pra ser mobilizado, se desfaça de um dia pro outro, né. As lutas não iam deixar de acontecer sem a gente, mas a gente é um acessório que facilita algumas coisas, ajuda em algumas coisas, destrava algumas coisas. Nesse sentido, né? Evita deles estarem perdendo tempo respondendo a processo, enfim, sendo preso, lidando com despejo violento. Que nem sempre a gente consegue evitar todas essas coisas, né. Que é mais uma prova de que é um acessório, né? [risos] Porque não é nem uma coisa garantida. Os protagonistas, isso eu espero que todo mundo do Escritório Popular tenha clareza, que nós não somos protagonistas dessas lutas. (E3).

Para compreendermos essa dimensão "acessória" e "de assessoria" caracterizadora da experiência extensionista do EP, analisaremos alguns aspectos da assessoria jurídica universitária popular.

\title{
3.2. Uma experiência de Assessoria Jurídica Universitária Popular
}

A essência do Escritório Popular foi a demanda do movimento social, especificamente o MST. Aí depois a gente ficou nisso. De acolher demandas dos movimentos sociais, entendeu? De entender o Escritório Popular como acolhedor, de fazer pactos políticos e disputar no poder Judiciário demandas dos movimentos sociais, entende? (E2) 
As assessorias jurídicas universitárias populares (AJUPs) nascem a partir da necessidade de compreender a realidade de dominação que subtrai os direitos e exclui, e, ao mesmo tempo, agir com o povo para transformá-la. Dessa maneira, a AJUP entende-se como popular, na medida em que enxerga o povo sendo constituído pelas classes dominadas (classe operária, industrial, camponesa, etc), mas, além disso, por outros grupos humanos oprimidos que não são classe dominante ou exercem práticas de classes esporadicamente (marginais, etnias, tribos, etc); é o povo como sujeito histórico da formação social, do país, da nação (DUSSEL apud ALFONSIN, 2009).

Para introduzir o debate sobre a caracterização do EP como uma experiência de assessoria jurídica popular, resgatamos pesquisas e estudos relacionados à Assessoria Jurídica Popular no Brasil que dialogam diretamente com o resgate da própria caminhada da experiência de AJP no país.

Na década de 1980 destacam-se as experiências e produções do Instituto de Apoio Jurídico Popular (IAJUP), no Estado do Rio de Janeiro; com Miguel Pressburger, Miguel Baldéz e o direito insurgente; e no DF, a experiência do Direito Achado na Rua (DANR), a partir da Nova Escola Jurídica Brasileira (NAIR) e das demandas de advogados e advogadas da Associação Nacional de Advogados das Lutas Populares (ANAP), antecedente da RENAP.

Na década de 1990, destaca-se o artigo de Celso Campilongo, com sua tipificação de serviços legais tradicionais e inovadores, bem como as publicações dos SAJUs ${ }^{105}$ mais antigos do Brasil, o Serviço de Assessoria Jurídica Universitária da Universidade Federal do Rio Grande do Sul (UFRGS) e o Serviço de Apoio Jurídico da Universidade Federal da Bahia (UFBA). Apesar de existirem desde as décadas de 1950 e de 1970, respectivamente, em seu surgimento tinham um caráter de assistência judiciária gratuita, uma vez que não existiam ainda os núcleos de prática jurídica. Somente na década de 1990 é que se deu o deslocamento político em que passaram a atuar e a se reconhecer como assessoria jurídica popular. É importante destacar, ainda nessa década, a criação das duas maiores e mais importantes redes de assessoria jurídica popular no Brasil até

105 Chamamos atenção para o fato de a mesma sigla "SAJU" ser utilizada para compreensões diferentes de serviços jurídicos: o de "assessoria jurídica universitária", na experiência da UFRGS, e o de "apoio jurídico", na UFBA. 
hoje, a RENAP, em 1995, e a Rede Nacional de Assessorias Jurídicas Universitárias (RENAJU), em 1996, 1997 ou $1998^{106}$.

Nos anos 2000 observamos o surgimento das primeiras monografias e dissertações sobre AJP, elaboradas por integrantes dos SAJUs, RENAJU e RENAP, ou seja, pelos sujeitos dessa práxis, e também destacamos as publicações das duas redes, os cadernos da RENAP e os da RENAJU.

Nos anos 2010 identificamos as primeiras teses sobre a temática, bem como, pesquisas realizadas por organizações de direitos humanos e que foram fomentadas por diferentes fontes. São exemplos: o "Estudo sobre advocacia popular" desenvolvido pelo Centro Brasileiro de Análise e Planejamento (CEBRAP, 2013) em parceria com o Centro de Estudos sobre o Sistema de Justiça (CEJUS), da Secretaria de Reforma do Judiciário do Ministério da Justiça (SRJ/MJ); a "Pesquisa Organismos Universitários de Direitos Humanos", que foi coordenada pelo professor Nelson Saule Junior com o apoio da Ford Foundation (SAULE JUNIOR et al, 2015); e os estudos promovidos pela organização não governamental "Terra de Direitos" (2010; 2011; 2015). ${ }^{107}$

Elaboramos um quadro sintetizando os principais marcos das AJPs no Brasil:
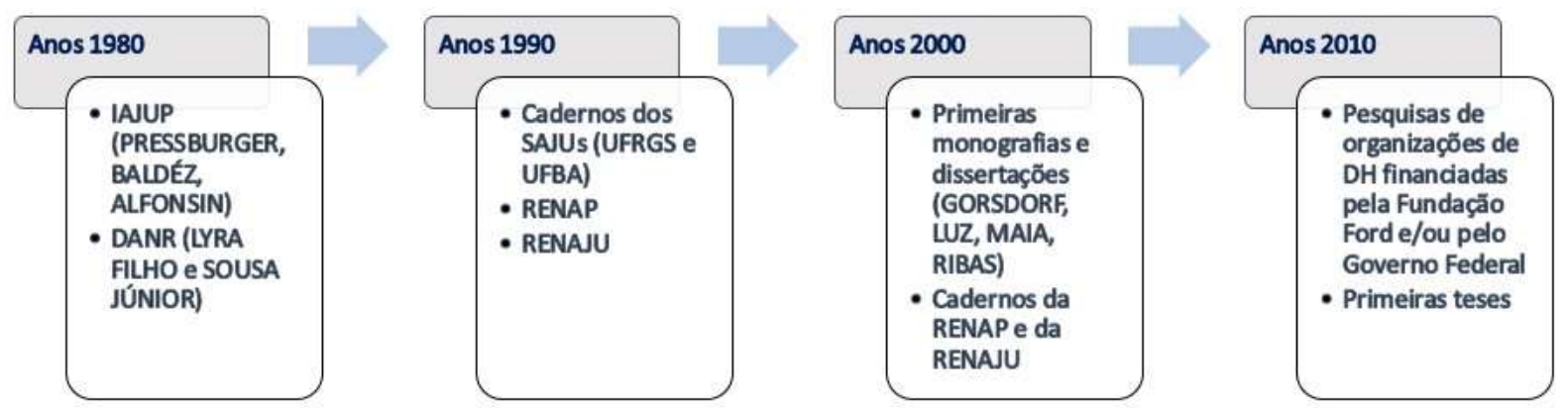

Figura 10: Principal produção sobre Assessoria Jurídica Popular no Brasil.

Fonte: elaboração da autora.

106 Sumaya Pereira e Assis de Oliveira $(2009$, p.3) em artigo dedicado à análise da história da RENAJU, identificam três datas diferentes apontadas como marcos do surgimento a RENAJU: 1996, 1997 e 1998. Para maiores detalhes sobre essa questão, conferir: PEREIRA; OLIVEIRA, 2009.

107 Consideramos ser relevante distinguir a experiência das clínicas de direitos humanos norte-americanas da de assessoria jurídica desenvolvida em contextos latino-americanos. As clínicas de direitos humanos são posteriores às experiências de AJUPs no Brasil, cujos primeiros SAJUs são datados da década de 1950, ou, minimamente, contemporânea às AJUPs (cuja articulação nacional e disseminação enquanto prática emancipatória no âmbito dos cursos de direito do Brasil se deu na década de 1990). Os pilares que a conceituam estão presentes nas práticas brasileiras, que são cronologicamente anteriores. Portanto, não faz sentido a submissão epistêmica à categoria norte-americana. Se essas práticas estadunidenses são posteriores às nossas da América Latina, por que não foram aquelas que se submeteram às nossas categorias, debates, teorizações e perspectivas? 
Carla Miranda (2010), em estudo sobre a práxis de AJUP, explica que:

No campo da extensão popular em Direito, há experiências que falam em
educação jurídica popular, educação popular em Direitos Humanos, prática
jurídica universitária emancipatória, dentre outras. Mas falamos aqui em
Assessoria Jurídica Universitária Popular, enquanto movimento crescente
nos cursos de Direito que por vezes englobam estas expressões, mas
trazem consigo uma história de referência nos movimentos teórico-
críticos do Direito da década de 1980, em especial a advocacia popular
aos movimentos sociais.
É desta referência um modo de fazer AJUP que tem como parceiro
fundamental os movimentos sociais ou grupos organizados em defesa de
Direitos Humanos, mas constituindo-se como extensão universitária tem
características das lutas desse seu local de origem. (MIRANDA, 2010, p.10,
grifo nosso)

Identificamos na pesquisa de campo que o EP apresenta essa característica de AJUP que é atribuída pela pesquisadora ao "modo de fazer AJUP" e que consiste em ter os movimentos sociais como parceiros. A persistência de adjetivações à atuação do EP tais como "acessório" e "não protagonista", e a percepção de que seu agir dá-se em diálogo e, principalmente, com os sujeitos coletivos de direito são alguns dos indicativos que revelaram essa caracterização.

Esses elementos não são unicamente tratados por Miranda (2010). Na revisão bibliográfica realizada sobre assessoria jurídica popular identificamos outros estudos dedicados à experiência extensionista e de AJUPs que corroboram essa compressão e trazem outras características reveladoras, tais como a auto-organização estudantil, a atuação junto a sujeitos subalternizados e o desenvolvimento no meio acadêmico. Nesse sentido, destacamos as pesquisas realizadas pelas professoras Ana Lia de Almeida (2015) e Fabiana Severi (2014):

Quanto ao segmento analisado aqui, marcado por um forte protagonismo estudantil, a assessoria jurídica universitária popular pode ser caracterizada como uma perspectiva ideológica ligada a certosgrupos estudantis do direito, que, de modo auto-organizado e geralmente ligados à extensão universitária, colocam-se ao lado dos trabalhadores e dos demais sujeitos subalternizados na sociedade de classes (ALMEIDA, 2015, p.77, grifo do original).

Quando a atividade é desenvolvida por profissionais junto a movimentos populares, sindicatos ou organizações não governamentais, o nome atribuído é Assessoria Jurídica Popular (AJP) ou Advocacia Popular (AP), como é conhecido no Brasil e na América Latina desde a segunda metade dos anos 19803. Se ela se desenvolve no meio acadêmico (em universidades, centros universitários ou faculdades), a designação mais utilizada é Assessoria Jurídica Universitária Popular (AJUP). (SEVERI, 2014, p.9). 
Assim caracterizada, identificamos como perspectiva que embasa a atuação das AJUPs a compreensão de que não há como prestar um serviço jurídico a um sujeito do povo sem uma profunda consciência do grau de injustiça sob o qual ele vive, sem um sentimento ético de indignação contra as causas desse mal, contra as irresponsabilidades que o criam e sem o domínio técnico dos remédios que a prevenção ou reparação da injustiça reclamam (ALFONSIN, 2009).

Entende-se, portanto, Assessoria Jurídica Universitária Popular (AJUP) como uma prática jurídica e educativa desenvolvida por estudantes de direito, e também de outros cursos, organizados em grupos de militância política estudantil na proposição e organização de projetos de extensão com comunidades de todo Brasil, a partir da década de 1990 (RIBAS, 2008). Cumpre perceber, então, que as AJUPs se apresentam como possibilidade de estratégia de democratização da justiça e, dentre seus elementos constituintes, a educação revela-se como um dos principais instrumentos de atuação, tanto pela perspectiva pedagógica do trabalho com as comunidades e movimentos com que atua, como pelo viés pedagógico na formação dos e das estudantes que a constituem.

As AJUPs, através da pesquisa-ação, buscam realizar a extensão universitária como comunicação (FREIRE, 1979): o processo de educação popular compreendido não como repasse mecanicista, dominador e antidialógico de conhecimentos, mas como coprodução de saber por sujeitos universitários e populares que o constroem na mesma medida em que constituem a si mesmos. Não se trata, pois, de a universidade educar ou conscientizar a comunidade, pois ninguém educa nem conscientiza ninguém; o processo é de conscientização conjunta (FREIRE, 2001), de educação que rompe com os muros universitários e se assume como prática de libertação na qual todos e todas são sujeitos criadores de conhecimento no bojo da luta por direitos.

\subsection{Direito e direitos humanos na fala e voz extensionista}

O campo permitiu a identificação de compreensões sobre direito e direitos humanos a partir das percepções das e dos extensionistas. A análise dos elementos constituintes dessas compreensões é relevante para o estudo da experiência do EP porquanto revela a sua prática em direito e direitos humanos. 
Conforme desenvolvemos nos capítulos iniciais, chamou a nossa atenção o destaque que as e os extensionistas deram ao "acordo político" ou "pacto" firmado entre - EP e os movimentos sociais, e a consequente diferenciação refletida na ação extensionista. Esse acordo/pacto guarda relação com os processos de luta que precisam ser travados pelos sem-direitos/oprimidos em busca do reconhecimento de seus direitos e de justiça em seus contextos, pois, de outro modo, a sistemática violação a que são submetidos restaria invisibilizada.

É no sentido de humanização, de genteficação que o EP atua e, para tanto, adota uma noção de direito e de direitos humanos que a sua prática, decorrente da realidade concreta, Ihe coloca. Para E2, a concepção de direitos humanos emergida da práxis do EP "[...] é a concepção de Direito ser construído, a mesma do Direito Achado na Rua, o Direito na História, o Direito como conquistas através de lutas no materialismo histórico-dialético." (E2).

Compreendemos essa referência ao DANR como movimento de demarcação política e pedagógica que encontra na ideia de deslocamento dos processos de lutas sociais para a centralidade da noção de direitos humanos o seu ponto de inflexão. Ao resgatarmos as noções de direitos humanos desenvolvidas por José Geraldo de Sousa Junior (2000) e Roberto Lyra Filho (1986), constatamos que, de fato, as compreensões expressas pelas e pelos extensionsistas dialogam e quase coincidem com as formulações teorizadas pelos autores.

\footnotetext{
Os direitos humanos são lutas sociais concretas da experiência de humanização. São, em síntese, o ensaio de positivação da liberdade conscientizada e conquistada no processo de criação das sociedades, na trajetória emancipatória do homem (SOUSA JUNIOR, 2000, p.183).

[direitos humanos são aqueles] conscientizados, reivindicados e exercidos pelos povos, classes, grupos e indivíduos em processo de libertação [...] vão surgindo no processo mesmo e que, só eles, podem validar derivações normativas, isto é, os incidentes de positivação, mediante os quais o Direito é formalizado. (LYRA FILHO, 1986, p.299).
}

Os elementos que emergem dessas definições e que as colocam dentro da teoria crítica dos direitos humanos são: conscientização, reivindicação, povo, libertação, humanização e lutas sociais concretas. Subjaz a ideia de que existe uma gama de sujeitos (o povo) cuja existência, em diferentes dimensões, é negada (fenômeno da opressão, da espoliação, da subalternização, da violação) e que a partir da tomada de consciência (a conscientização) e da organização de suas vindicações (as lutas sociais 
concretas), adquirem as condições mínimas necessárias (a constituição em sujeitos coletivos de direito) para atuar contra essa negação existencial (o movimento pela libertação) e serem reconhecidos enquanto sujeitos (é a dimensão da humanização).

As concepções indicadas nas entrevistas dão ênfase à dimensão de luta, de conquista por direitos, denotando que os direitos humanos não estão reduzidos ou limitados aos dispositivos arrolados em leis (positivados). Mas, ao contrário, são expressões em expansão e que decorrem de processos, de um vir-a-ser. Para E3:

Imagino que a concepção de direitos humanos com que o Escritório Popular atue seja aquela concepção de construção, de que direitos, aquela clássica né: direitos não são dádivas, são conquistas. Porque eu vejo isso muito quando a gente vai explicar uma decisão, vai conversar numa assembleia de acampados, sei lá, a conversa é nesse sentido, entendeu? Deixando claro que o judiciário não é parceiro, que as leis são feitas contra a gente, e que só na luta mesmo é que a gente vai conseguir o direito tal. Normalmente, pelos discursos que a gente tem com os nossos, como é que chama, nossos "assessorados", quando a gente vai explicar as coisas, eu acho até que isso deve até ser consensual. Essa concepção de que direito é luta. Pra ter acesso a direitos humanos, só com luta, porque não há nada que vão lhe dar de presente, que vai ser dado. Acho que é essa concepção, de luta. (E3, grifos nossos).

Essa compreensão, ao enfatizar o aspecto da "luta", desloca o protagonismo do Estado na titularidade, na produção e, principalmente, na legitimidade dos direitos humanos, e para o povo. Nesse movimento, o EP desloca a expressão dos direitos humanos do abstrato para o real. É o que explica E4:

Primeiro que a gente tem um risco de falar dos direitos humanos como gerais....você poderia dividir... usar aquela distinção de gerações só pra ter um recorte. A gente tem uma primazia pelos direitos sociais, direitos coletivos e direitos culturais, econômicos também, em detrimento do que seria aquela primeira parte do individual, do político, certo? Que também existe, que também é necessário, mas se fosse falar dos direitos humanos em si, você vai ter uma primazia de um determinado recorte, que pra mim seria esse...que seria o que significa: a necessidade de uma prestação do Estado, uma obrigação a ser cumprida por ele ou de respeitar algumas liberdades... essas liberdades seriam mais relacionadas ao dever de abstenção do Estado, por exemplo, inviolabilidade de domicílio... você nunca vê uma polícia chegando com um mandado... com a ordem do juiz dizendo ali que vai entrar na casa, que vai respeitar todo mundo, que vai ter...manter a dignidade de todo mundo ali. Não tem isso e aí é um recorte dos direitos humanos que a gente utilizaria em detrimento de outros direitos que poderão ser utilizados, tanto a nível conservador da realidade, como esses que são mais ligados a uma igualdade formal ou a uma liberdade formal, eu acho; tá mais associado a uma igualdade material, a um dever do Estado de cumprir, e que se trata da localidade, assim... a gente não se relaciona muito com o direito internacional, com os direitos humanos dos tratados e de convenções internacionais, eu acho que não é uma tradição do escritório popular, porém, seria um recurso cabível em algumas demandas coletivas, no sentido de que, esgotado o Estado, você poderia ir para a corte interamericana, mas se você não preparar a petição inicial, com aquilo, pra que seja pre-questionado, pra que tenha tudo discutido, nem você sobre pro STF nem pro STJ, nem você vai subir pra corte interamericana. (E4). 
Essa distinção se mostra presente no campo de formação prática previsto no curso de direito. Segundo E4 e E5, a noção de direitos humanos ensinada na graduação e, portanto, no ensino formal em direito, é limitada a teorias abstratas que guarda como características o academicismo, o formalismo, a ênfase na dimensão positivada das normas e o afastamento - para não dizer discrepância - em relação à realidade concreta:

Eu aprendi direitos humanos (risos) na constitu... na faculdade com um professor que me deu só as teorias de interpretação de direitos humanos; me deu 6 teorias e foi isso a gradu...o semestre todinho. Fora isso, direito internacional, eu li as convenções; mas foi muito mais importante o recorte quanto às cláusulas que não seriam aplicadas ao governo brasileiro...que o governo via o tratado e dizia: 'não, isso daqui eu me abstenho', por exemplo, do que o acesso às cortes internacionais, enfim, o acesso à justiça de modo geral que teria muita relevância porque já teve caso, no Brasil, que era de população carcerária, que foi pra lá 'o massacre da população carcerária', você tem o acesso à justiça, das famílias, que foi o caso do Gomes Lund do Araguaia, por exemplo; e esse enfoque mais prático, a gente nunca viu e agora a gente teve a federalização do conflito do Manoel Mattos, que é um ato exclusivo - foi o primeiro caso que a gente observou ser feito, daquele de federalizar o conflito e poderia ser muito aplicado aqui, ser demais. Então, tem utilidade, tem relevância prática, mas a gente nunca viu isso; o foco na graduação foi pela formalidade, aí a gente se preocupava mais com a incorporação do tratado internacional no sentido formal, ou seja, o processo legislativo que passava por ali, desde a assinatura do presidente, do poder executivo, até o processo no congresso; do que, de fato, observar como é que esse tratado, em caso de descumprimento, seria resolvido, ou seja, como lidar com aquilo ali....você não tem isso. A nossa graduação tem uma falha nisso que vai repercutir no momento que a gente vai discutir a demanda. [...] e eu nunca usei na minha vida as 7 teorias que eu aprendi na graduação. (risos) Enfoque prático é de eu saber, por exemplo, é...esse caso da federalização...eu deveria ter estudado ele porque era é uma efervescência na época da graduação, ele foi julgado agora, mas já era uma efervescência naquela época. Ele é muito antigo, na verdade. O caso do Araguaia eu não vi, e é um caso de acesso à justiça, acesso ao poder judiciário, acesso à corte internacional, ou seja, isso me permitiria observar melhor algumas demandas, que eu poderia olhar hoje, como eu disse, o advogado em si não sabe preparar uma peça pra ser discutida no STF, STJ, quanto mais pra ir pra uma corte internacional, certo? você não prepara desde o início ali dizendo 'ó, se você não for, certo?' você pode levar dali. (E4).

Não porque a visão que a gente tem de direitos humanos, pelo menos que eu tive do curso de direito na UFRN, é uma visão muito abstrata, né? Tipo assim, quando você vê lá, um estudante chega, tipo, um estudante lá, classe média, que só sabe a realidade de casa pra faculdade, do seu convívio social, no seu... Na sua classe social, olha assim, tipo, "ah, tá aqui, todo mundo ta dizendo que tem direito a saúde, tem direito a educação, tem direito a trabalho digno, salário mínimo, ta ra rá...". E aquilo é uma ficção jurídica, né? Porque quando a gente bebe da realidade a gente vê que direitos humanos não é aquilo que tá no papel. Porque se aquilo ali fosse suficiente, se aquilo que tivesse no papel fosse suficiente, meio que cria uma ilusão até no estudante de direito, uma ingenuidade de achar que a gente vai chegar lá, no judiciário, vai reivindicar o artigo $5^{\circ}$ e vai dar certo, né? Tem uma série de questões aí no meio, saber conjuntura mesmo, saber constituição de sociedade, das condicionantes, dos fatores históricos, isso o curso não dá, né? (E5, grifos nossos). 
Já a concepção de direitos humanos revelada pela práxis do EP seria diametralmente diferente daquela fórmula prevista e engessada pelo ensino formal e se aproximaria da conflituosidade vivenciada pelo povo na realidade concreta.

Eu acho que a concepção de direitos humanos que a gente tem é, eu acho que é de luta mesmo, né? É de direito que se constrói, que não se pede, que não se dá, mas que se conquista. Então, assim, eu pensei nisso, mas ao mesmo tempo eu fico pensando na, não deixa de ser, mas, no sistema carcerário, por exemplo, é difícil dizer isso, né? Porque os sujeitos estão muito mobilizados, mas de qualquer forma, a gente acredita muito, nos direitos humanos enquanto construção mesmo, enquanto luta, reivindicação dos protagonistas, e não assim, a gente se vale daquilo, tipo assim, direito à moradia, artigo $5^{\circ}$ e tal, se vale disso meio que pra, pra ser uma forma de... Um argumento, né? Mas no fundo, os direitos mesmo são construídos a partir das trincheiras mesmo. (E5).

Primeiro, de novo, o risco do uso do termo 'direitos humanos'...ele pode dar vazão a você manter as coisas como estão ou como buscar uma transformação... é...por exemplo, eu lembro na graduação (risos), eu usava muito 'direitos humanos' como 'direito ao desenvolvimento', que é uma perspectiva totalmente econômica, totalmente em detrimento de outras garantias...e isso é prejudicial, isso é uma argumentação, você tem esse risco da universalização do termo, a abrangência dele. Mas enfim, o escritório popular, na efetivação de direitos, ele não liga tanto, por exemplo, uma distinção fundamental... ou direitos humanos ou qual sua relação de tratados internacionais; ele pega mais os direitos, que eu entendo assim, fundamentais, sociais, ali, que tão na constituição, no ordenamento interno, propriamente dito e leva adiante, mas é uma concepção que já não é mantenedora, ela é pra transformação daquilo; ele observaria, por exemplo, a força normativa daquilo tudo e a necessidade de obediência das políticas pelo Estado, uma responsabilização do Estado diante da omissão, das ausências; e é uma concepção diferente da graduação, porque a graduação não tem enfoque prático, não tem enfoque transformador (E4).

As percepções obtidas em campo referente à noção de direito adotada pelo

EP seguem as mesmas especificações identificadas para direitos humanos. Como observa E7:

Eu acho que a concepção de Direito que o Escritório Popular adota é uma concepção que não existe na nossa grade curricular, na verdade ... [...] eu acho que é isso. Que tá ligado a concepção mais crítica, mais de um olhar mais voltado pra fora que é.... Crítica ao que tá, assim, por exemplo, crítica ao que tá, ao que prevalece no Direito. Que o que é que prevalece? Prevalece a manutenção de privilégios, a manutenção da propriedade, a manutenção, 0 encarceramento das pessoas pobres. É isso que prevalece, que a gente vê na prática e aí isso é decorrente de uma estrutura social e ai uma concepção mais crítica a isso. Crítica ao encarceramento dos pobres, crítica a o Direito à propriedade como um direito absoluto. Tudo isso. (E7).

Chegamos, assim, à matriz político-conceitual que marca essa experiência extensionista em contraste com a prática hegemônica no ensino do direito e na atuação do sistema de justiça, e contra as quais identificamos a possibilidade para 
uma pedagogia da justiça: o engajamento com uma perspectiva transformadora da realidade social.

E é justamente essa faceta de transformação social que se apresenta como maior desafio à prática jurídica popular e que é encampada como projeto de vida, de direitos humanos e de sociedade.

A respeito, destacamos a recente produção de José Geraldo de Sousa Junior e Antônio Escrivão Filho (2016), ao lançarem elementos para um debate teóricoconceitual e político sobre os direitos humanos. Os autores analisam e criticam fundamentadamente os elementos geracionalidade, indivisibilidade, interdependência e integralidade dos direitos humanos para, então, concluírem que:

[...] o debate conceitual dos direitos humanos encontra, como fundamento teórico, um caminho orientado pela ação humana organizada em processo de libertação. Assim, os direitos humanos voltam ao domínio do agir humano, de modo que se compreenda que eles são efetivamente construídos e desconstruídos, reconhecidos e negados, efetivados e violados na dialética da história. Perceba-se que, dessa forma, caem por terra alguns dos elementos definidores dos direitos humanos no âmbito das teorias abstratas, em especial, a sua condição absoluta e a sua validade universal. (ESCRIVÃO FILHO; SOUSA JUNIOR, 2016, p.31). 


\section{CONSIDERAÇÕES FINAIS}

Desenvolvemos a pesquisa acadêmica com objetivo de estudar a práxis do Escritório Popular (EP) do Programa Motyrum de Educação Popular em Direitos Humanos, ação extensionista desenvolvida na Universidade Federal do Rio Grande do Norte (UFRN) desde 2010.

Ao término das análises e redação da dissertação, consideramos que identificamos elementos que denotam a configuração do EP como ponte entre a assessoria jurídica universitária popular (AJUP) e a advocacia popular, e cujo "quefazer" adquire contornos democratizantes para a justiça.

A partir da realização de oito entrevistas com extensionistas do projeto, da condução de um grupo focal com os mesmos sujeitos, da revisão bibliográfica sobre o tema e da análise documental, conseguimos dados e informações relevantes para apresentarmos o programa de extensão universitária (Motyrum) em que se situa o projeto estudado e descrever o desenho organizativo e institucional do EP.

Os primeiros achados da pesquisa guardam relação com a identificação de uma rica trajetória de um projeto de extensão nordestino. Uma iniciativa protagonizada por estudantes do curso de direito de uma universidade pública federal localizada na região mais pobre do Brasil que de forma criativa e inovadora desafia os limites colocados pela institucionalização de uma educação bancária, tecnicista e elitizada, e engaja-se com conflitos populares em busca da transformação da realidade na qual está inserida.

Os segundos achados da pesquisa remetem às concepções de direito e de direitos humanos identificados na ação extensionista e que foram forjadas a partir da práxis junto a movimentos sociais populares no contexto potiguar. A realidade de sistemáticas violações a direitos e negações de justiça à que foram submetidos diferentes grupos sociais não foi suficiente para conter sua existência no contexto analisado e, principalmente, revelam um espaço de conflituosidade social da qual emergem importantes reivindicações populares que, por sua vez, revelam novas expressões de direito e de justiça que podem e são captadas pelo EP. Nesse sentido, o EP constitui-se uma experiência extensionista da qual emergem não só compreensões como, também, práticas contrahegemônicas no campo do direito e dos direitos humanos. 
Outra gama de achados que merecem ser mencionada diz respeito aos múltiplos vetores que identificamos na práxis extensionista e que, contrariando o tradicional padrão de atuação técnica-jurídica vigente no ordenamento jurídico e sistema de justiça brasileiro, desloca o protagonismo na resolução do conflito do bacharel em direito para o sujeito coletivo de direito. Foi particularmente relevante observar uma prática jurídica que coloca como protagonista os sem-direitos, os oprimidos e os grupos historicamente dominados, explorados e excluídos. Assim, o EP figura como experiência inovadora no campo do direito e dos direitos humanos que supera os estreitos limites colocados pela compreensão formal dos direitos humanos e passa à ação engajada para formulação dialógica e dialética de estratégias para a sua materialização cidadã.

Consideramos que esses múltiplos deslocamentos caracterizam o quefazer do projeto e viabilizam um ganho qualitativo no que se refere à sua atuação frente à justiça, em sentido amplo. São eles que permitem, na linha do que é desenvolvido por O Direito Achado na Rua, desde a década de 1980, uma transformação radical no campo do ensino universitário do direito e dos direitos humanos e, acima de tudo, propicia uma pedagogia da justiça voltada para o desvelamento da realidade a partir de novas leituras de mundo enxergadas com os olhos dos sujeitos coletivos de direito e partir de perspectivas localizadas no vértice dos espoliados e oprimidos. E é justamente aí que reside a atitude pedagógica do EP: sua prática democratizante da justiça é reveladora e potencialmente multiplicadora desses desvelamentos e transformação social da realidade. 


\section{REFERÊNCIAS}

ALTHUSSER, Louis. Aparelhos ideológicos de estado: nota sobre os aparelhos ideológicos de estado. 3. ed. Rio de Janeiro: Graal, 1985.

ANDRADE, Carlos Drummond. Nosso Tempo. In: A rosa do povo. 1945.

ARAÚJO, Thiago Matias de Sousa. A experiência educativa do Lições de Cidadania (2005-2013). 2014. Dissertação (Mestrado em Educação) - Universidade Federal do Rio Grande do Norte, Natal, 2014.

BARBOUR, Rosaline. Grupos focais. Porto Alegre: Artmed, 2009.

BEZERRA, Hélio Miguel Santos; BONAVIDES, Natália Bastos. A extensão universitária popular: a aproximação do curso de direito com a realidade. In: SEMINÁRIO DE PESQUISA DO CCSA - UFRN, 16, 2010, Natal. Anais .... Natal, online. Disponível em: $<$ http://docplayer.com.br/8356087-A-extensao-universitaria-popular-a-aproximacao-docurso-de-direito-com-a-realidade.html>. Acesso: 2 ago. 2016.

BOFF, Leonardo. Quarenta anos da teologia da libertação. Online, 9 ago. 2011. Disponível em: <https://leonardoboff.wordpress.com/2011/08/09/quarenta-anos-dateologia-da-libertacao/>. Acesso: 23 fev. 2016.

BRANDÃO, Carlos Rodrigues. O que é o método Paulo Freire. Brasiliense, 1981.

BRASIL. Constituição da República Federativa do Brasil, de 5 de outubro de 1988. Diário Oficial da União, Brasília, Poder Legislativo, p.1, anexo, 5 out. 1988. Disponível em: <http://www.planalto.gov.br/ccivil_03/Constituicao/Constituicao.htm>. Acesso: 13 abr. 2016.

CARLET, Flávia. Advocacia popular: práticas jurídicas e sociais no acesso ao direito e à justiça aos movimentos sociais de luta pela terra. 2010. Dissertação (Mestrado em Direito) - Faculdade de Direito, Universidade de Brasília, Brasília, 2010.

CHAUÍ, Marilena. O que é ideologia. 22. ed. São Paulo: Brasiliense, 1986. (Primeiros Passos, 13).

CAPPELLETTI, Mauro; GARTH, Bryant. Acesso à justiça. Trad. e rev. Ellen Gracie Northfleet. Porto Alegre: Sergio Antonio Fabris, 1988.

CASTRO, Fidel. A história me absolverá: discurso de Fidel Castro ante o Tribunal de Exceção de Santiago de Cuba, proferido em 16 de outubro de 1953. São Paulo: AlfaOmega, 1979.

CAVALCANTE, André Felipe Bandeira; CHACON, Eric Luiz Martins; MEDEIROS, Érika Lula de; GOMES, Maíra Mendonça; CHAVES, Raul Rocha. Assessoria Jurídica Popular no RN: A Prática do Escritório Popular na Defesa de Direitos. In: SEMINÁRIO DIREITOS PESQUISA E MOVIMENTOS SOCIAIS, 2, 2012, Goiás. Anais....Goiás, 2012. 
COMISSÃO PASTORAL DA TERRA (CPT). Conflitos no Campo: Brasil 2015. [Coordenação: Antônio Canuto, Cássia Regina da Silva Luz, Thiago Valentim Pinto Andrade - Goiânia]: CPT Nacional - Brasil, 2015. Disponível em: $<$ http://www.cptnacional.org.br/index.php/publicacoes/conflitos-no-campo-brasil>. Acesso: 27 abr. 2016.

COMISSÃO PASTORAL DA TERRA (CPT). Conflitos no Campo Brasil 2010. Antônio Canuto, Cássia Regina da Silva Luz, Isolete Wichinieski. Goiânia: CPT, 2011.

COSTA, Alexandre Bernardino (Org.). Direito vivo: leituras sobre constitucionalismo, construção social e educação a partir do direito achado na rua. Brasília: Ed. UnB, 2013. (Direito vivo, v.1).

DENZIN, Norman K.; LINCOLN, Yvonna S. O planejamento da pesquisa qualitativa: teorias e abordagens. 2. ed. Porto Alegre: Artmed, 2006.

DUSSEL, Enrique. Ética comunitária: liberta o pobre! Petrópolis: Vozes, 1986.

Hacia una filosofia política crítica. Bilbao: Desclée de Brouwer, 2001.

ESCRIVÃO FILHO, Antonio; SOUSA JUNIOR, José Geraldo de. Para um debate teóricoconceitual e político sobre os direitos humanos como um projeto de sociedade. In: PINTO, João Batista Moreira; SOUZA, Eron Geraldo de (orgs). Os direitos humanos como um projeto de sociedade: desafios para as dimensões políticas, socioeconômica, ética, cultural, jurídica e socioambiental. Rio de Janeiro: Lumen Juris, 2015. v. 1.

ESCRIVÃO FILHO, Antonio [et al.] Justiça e direitos humanos: perspectivas para a democratização da justiça. Curitiba: Terra de Direitos, 2015.

FARIA, Dóris Santos de (org). Construção conceitual da extensão universitária na América Latina. Brasília: Ed. UnB, 2001.

FERNANDES, Florestan. O destino das Universidades. Boletim Informativo da CAPES, no 75 , fevereiro, 1959, p. 1-2.

FONSECA, Lívia Gimenes Dias da; RAMPIN, Talita Tatiana Dias. As lutas populares por direitos e as (in)transições brasileiras no contexto latino-americano. In: SOUSA JUNIOR, José Geraldo de et al. (org.). O direito achado na rua: introdução crítica à justiça de transição na América Latina. 1. ed. Brasília: UnB, 2015. v.7.

FORPROEX. Política Nacional de Extensão. Online. 2012. Disponível em: $<$ http://www.renex.org.br/documentos/2012-07-13-Politica-Nacional-de Extensao.pdf>. Acesso: 25 fev.2016.

FORPROEX. Encontro Nacional do FORPROEX. Online. 2015. Disponível em $<$ http://www.renex.org.br/index.php?option=com_content\&view=article\&id=166:380encontro-nacional-do-forproex\&catid=1:noticias>. Acesso: 25 fev.2016. 
FREIRE, Ana Maria. Prefácio à nova edição. In: LIMA, Venício A. de. Comunicação e cultura: as ideias de Paulo Freire. 2.ed.rev. Brasília: Universidade de Brasília: Fundação Perseu Abramo, 2011.

FREIRE, Paulo. Extensão ou comunicação? 4. ed. Rio de Janeiro: Paz e Terra, 1979.

Conscientização: teoria e prática da libertação. Uma introdução ao pensamento de Paulo Freire. 3. ed. São Paulo: Centauro, 2001.

Pedagogia da autonomia: saberes necessários à prática educativa. 25. ed. São Paulo: Paz e Terra, 1996. (Coleção Leitura).

Pedagogia da indignação: cartas pedagógicas e outros escritos. São Paulo: UNESP, 2000.

Pedagogia do oprimido. Rio de Janeiro: Nova Fronteira, 2012.

Pedagogia da esperança: um reencontro com a pedagogia do oprimido / Paulo Freire. Rio de Janeiro: Paz e Terra, 1992.

FREIRE, Paulo; HORTON, Myles. O caminho se faz caminhando: conversas sobre educação e mudança social. 5. ed. Petrópolis: Vozes, 2009.

FRIGO, Darcy; ESCRIVÃO FILHO, Antônio Sérgio. Justiça e direitos humanos: experiências de assessoria jurídica popular. Curitiba: Terra de Direitos, 2010.

GADOTTI, Moacir. A voz do biógrafo brasileiro: A prática à altura do sonho. In: GADOTTI, Moacir (Org). Paulo Freire: uma bibliografia. São Paulo: Cortez, 1996. p.69-115.

A escola e o professor: Paulo Freire e a paixão de ensinar. 1. ed. São Paulo: Publisher Brasil, 2007.

GALLARDO, Helio. Teoría crítica: matriz y posibilidad de derechos humanos. Sevilla: David Sanchez Rubio, 2008.

GEDIEL, José Antônio Peres; GORSDORF, Leandro; ESCRIVÃO FILHO, Antonio (et al). Mapa territorial, temático e instrumental da assessoria jurídica e advocacia popular no Brasil. Belo Horizonte: Observatório da Justiça Brasileira; CES/AL, 2011.

GENTILI, Pablo. (Org.). Pedagogia da exclusão: crítica ao neoliberalismo em educação. Petrópolis: Vozes, 1995

GERHARDT, Heinz-Peter. Uma voz europeia: Arqueologia de um pensamento. In: GADOTTI, Moacir (Org). Paulo Freire: uma bibliografia. São Paulo: Cortez, 1996. p.149170.

GÓES JUNIOR, José Humberto de. "O que é Direito, para que se possa ensiná-lo?". As percepções dos sujeitos sobre o Direito, o "Ensino Jurídico" e os Direitos Humanos. 2015. Tese (Doutorado em Direito) - Faculdade de Direito, Universidade de Brasília, Brasília, 2015. 
GOHN, Maria da Glória. Novas teorias dos movimentos sociais. 5. ed. São Paulo: Loyola, 2014.

GONÇALVES, Nadia Gaiofatto; VIEIRA, Carina Silva. Extensão Universitária no período da ditadura: concepções e relações com a Doutrina de Segurança Nacional e Desenvolvimento. Antíteses, Londrina, v.8, n.15, p.269-291, jan./jun. 2015.

GORSDORF, Leandro Franklin. Advocacia popular na construção de um novo senso comum jurídico. 206 fl. 2004. Dissertação (Mestrado em Direito) - Universidade Federal do Paraná, Curitiba, 2014.

GRUPPI, Luciano. O conceito de hegemonia em Gramsci. Rio de Janeiro: Graal, 1978.

GUIMARAES, Antonio Sérgio Alfredo. A recepção de Fanon no Brasil e a identidade negra. Novos estudos CEBRAP, São Paulo, online, n. 81, p. 99-114, jul. 2008. Disponível em: <http://www.scielo.br/scielo.php?script=sci_arttext\&pid=S010133002008000200009\&lng=en\&nrm=iso >. Acesso: 5 maio 2016.

HERNANDEZ, A. R. C. Análise qualitativa usando o programa QDA Miner - Um exemplo aplicado de pesquisa: análise documental de textos de protesto. In Scarparo, H. (Org.), Psicologia e Pesquisa: perspectivas metodológicas. Porto Alegre: Sulina, 2008. p. 151-168.

HIDAKA, Renato Kendy. Paulo Freire, leitor de Marx: Nexos entre política, educação e emancipação. INTRATEXTOS, Rio de Janeiro, 4(1): 126-136, 2012.

HERRERA FLORES, Joaquín. A reinvenção dos direitos humanos. Trad. Carlos Roberto Diogo Garcia; Antônio Henrique Graciano Suxberger; Jefferson Aparecido Dias. Florianópolis: Ed. Fundação Boiteux, 2009.

Teoria crítica dos direitos humanos: os direitos humanos como produtos culturais. Trad. Luciana Caplan, Carlos Roberto Diogo Garcia, Antônio Henrique Graciano Suxberger e Jefferson Aparecido Dias. Rio de Janeiro: Lumen Juris, 2009.

HINKELAMMERT, Franz J. Hacia una crítica de la razón mítica: el laberinto de la modernidade - materiales para la discusión. San Jose: Arkelín, 2007.

JESUS, Antonio Tavares de. Educação e hegemonia no pensamento de Antonio Gramsci. São Paulo: Cortez; Campinas: Ed. Universidade de Campinas, 1989.

LENTZ, Rodrigo. A participação de setores da sociedade civil na Ditadura Civil-Militar brasileira. In: SOUSA JUNIOR, José Geraldo de et al. (org.). O direito achado na rua: Introdução crítica à justiça de transição na América Latina. 1.ed. Brasília: UnB, 2015. (O Direito Achado na Rua, 7). p.319-324.

LIMA, Venício A. Cultura do silêncio e democracia no Brasil: ensaios em defesa da liberdade de expressão (1980-2015). Brasília: Ed. UnB, 2015. 
LUDWIG, Celso Luiz. Para uma filosofia jurídica da libertação: paradigmas da filosofia, filosofia da libertação e direito alternativo. Florianópolis: Conceito, 2006.

LYRA FILHO, Roberto. O que é direito? Rio de Janeiro: Brasiliense, 2003.

Para um direito sem dogmas. Porto Alegre: Sergio Antonio Fabris, 1980.

O direito que se ensina errado: sobre a reforma do ensino Jurídico. Brasília: Centro Acadêmico de Direito da UnB, 1980.

Pesquisa em que Direito? Brasília: Nair Ltda, 1984.

LUZ, Vladmir de Carvalho. Assessoria jurídica popular no Brasil: marcos teóricos, formação histórica e perspectivas. Rio de Janeiro: Lumen Juris, 2014.

MACHADO, Antônio Alberto. Ensino jurídico e mudança social. 2. ed. São Paulo: Atlas, 2009.

MACHADO, Maria Salete Kern; SOUSA, Nair Bicalho de. Ceilândia: mapa da cidadania: em rede na defesa dos direitos humanos e na formação do novo profissional do direito. Brasília: UnB, Faculdade de Direito; Secretaria de Direitos Humanos/MJ, 1998.

MAIA, Christianny Diógenes. Assessoria jurídica popular: teoria e prática emancipatória. 2007. Dissertação (Mestrado em Direito). Universidade Federal do Ceará, Fortaleza, 2007.

MARX, Karl; ENGELS, Friedrich. A ideologia alemã seguido das teses sobre Feuerbach. Tradução Álvaro Pina. São Paulo: Moraes, 1984.

MELO NETO, João Cabral de. Morte e Vida Severina e Outros Poemas para Vozes. 4.ed. Rio de Janeiro: Nova Fronteira, 2000.

MELO NETO, José Francisco de. Extensão universitária: diálogos populares. João Pessoa: Editora da Universidade Federal da Paraíba, 2002.

MENDES, Alexandre. Joaquín Herrera Flores e a Dignidade da Luta. Lugar Comum Estudos de Mídia, Cultura e Democracia. Rio de Janeiro, v. 2, n. 1, pp. 19-36, 2011.

MÉSZÁROS, István. A educação para além do capital. 2.ed. São Paulo: Boitempo Editorial, 2008. Boitempo, 2004.

O poder da ideologia. Tradução de Paulo Cezar Castanheira. São Paulo:

MIGNOLO, Walter D. El pensamiento decolonial: desprendimiento y apertura. Un manifiesto. In: CASTRO-GÓMEZ, Santiago; GROSFOGUEL, Ramón. El giro decolonial: reflexiones para una diversidad epistémica más allá del capitalismo global. Bogotá: Siglo del Hombre Editores; Universidad Central, Instituto de Estudios Sociales Contemporáneos y Pontificia Universidad Javeriana, Instituto Pensar, 2007. p.25-46. 
Desobediencia epistémica: retórica de la modernidad, lógica de la colonialidad y gramática de la descolonialidad. Buenos Aires: Del Signo, 2010.

MINISTÉRIO DA EDUCAÇÃO (2006a). Relatório de gestão. Online. $<$ http://portal.mec.gov.br/index.php?option=com_docman\&view=download\&alias=20511sesu-relatorio-gestao-2006-pdf\&ltemid=30192>.

MINISTÉRIO DA EDUCAÇÃO. Secretaria de Educação Superior (SESu)/ Secretaria de Educação Continuada, Alfabetização e Diversidade (SECAD)/ Ministério da Justiça (MJ), Departamento Penitenciário Nacional (DEPEN). Edital no 4, de 21 de março de 2006. Convoca as Faculdades de Direito das Universidades públicas e privadas comunitárias a apresentarem Projetos na área de ensino, pesquisa e extensão universitária ao Programa Reconhecer - ressignificando o ensino de direito e construindo práticas emancipatórias, que contemplará a formação cidadã dos(as) profissionais e estudantes da área de Direito, orientada pela perspectiva dos direitos humanos e da emancipação social. O Programa tem como pressuposto a promoção do Direito como relevante instrumento de mudança, a partir do estímulo a uma nova cultura jurídica. D.O.U., Brasília, v. 143, n. 56, p. 43, 22 mar. 2006. Seção 3.

MINISTERIO DA EDUCAÇÃO (2006b). Notícias. Programa Reconhecer tem 44 projetos inscritos. Online, 29 de maio de 2006. Disponível em: $<$ http://portal.mec.gov.br/index.php?id=6366\&option=com_content\&task=view>. Acesso: 20 ago. 2015.

MINISTÉRIO DA JUSTIÇA. Portaria ํo 1.587, de 29 de agosto de 2008. Institui o Projeto "PACIFICAR: Fomento à Prática da Mediação nas Faculdades de Direito". Diário Oficial da União, Brasília, 1 set. 2008, n.168, Seção 2, p.33.

MOLINA, Mônica Castagna; SOUSA JÚNIOR, José Geraldo de; TOURINHO NETO, Fernando da Costa (orgs.). Introdução crítica ao direito agrário. Brasília: Ed. UnB; São Paulo: Imprensa Oficial, 2002. (O Direito Achado na Rua, v. 3).

MOTYRUM. Lista de candidatos com inscrição homologada para o "I Curso de Extensão - Universidade, movimentos sociais e educação popular". Online. Publicado aos 19 ago. 2011. Disponível em: <http://www.programamotyrum.blogspot.com.br/2011/08/ista-de-candidatos-cominscricao.html>. Acesso: 24 fev. 2016.

MOTYRUM. Escritório popular. Informação online. Disponível em: <http://programamotyrum.blogspot.com.br/p/escritorio-popular.html>. Acesso: 22 jun. 2015.

MOTYRUM. I ENEDEx - Manifesto Extensionista. 4/8/2010. Disponível: <http://programamotyrum.blogspot.com.br/2010/08/i-enedex-manifestoextensionista.html>. Acesso: 31 jan. 2016.

MOTYRUM. Edital do I Curso de Extensão - Universidade, movimentos sociais e educação popular. 08/08/2011. Disponível em: $<$ http://www.programamotyrum.blogspot.com.br/2011/08/edital-do-i-curso-deextensao.html>. Acesso 24 fev.2016. 
MOTYRUM. O que está sendo o Motyrum?. Disponível em: $<$ http://programamotyrum.blogspot.com.br/p/o-que-esta-sendo-o-licoes.html>. Acesso: 31 jan. 2016.

MOTYRUM. Formação-seleção do Programa Lições de Cidadania: fases e leituras. Online. 12/08/2010. Disponível em: <http://www.programamotyrum.blogspot.com.br/2010/08/formacao-selecao-do-programalicoes-de.html>. Acesso: 23 fev.2016.

MOTYRUM (2011). Horário das entrevistas atualizado. Online. 2011. Disponível em: <http://www.programamotyrum.blogspot.com.br/2011/10/horario-das-entrevistasatualizado.html>. Acesso: 24 fev.2016.

MPMG Ministério Público do Estado de Minas Gerais. Coordenadoria de Inclusão e Mobilização Sociais (CIMOS). Associações comunitárias: guia prático e dúvidas frequentes. [Belo Horizonte]: CIMOS, 2010. Disponível em: <wwwantigo.mpmg.mp.br/portal/public/interno/arquivo/id/17157 >. Acesso: 27 abr. 2016.

MLB Movimento de Luta nos Bairros, Vilas e Favelas. Quem somos. MLB, essa luta é pra valer! Online. Disponível em: <http://www.mlbbrasil.org/\#!our_team/cqn6>. Acesso: 13 abr. 2016.

MPA Movimento de Pequenos Agricultores. Online. Disponível em: <http://www.mpabrasil.org.br/>. Acesso: 13 abr. 2016.

MST Movimento Sem Terra. Quem somos. Online. Disponível em: <http://www.mst.org.br/quem-somos/>. Acesso: 13 abr. 2016.

OBIJUV Observatório da População Infanto-Juvenil em Contextos de Violência. Quem somos. Online. Disponível em: <http://www.cchla.ufrn.br/obijuv/quemSomos.php >. Acesso: 13 abr. 2016.

OLIVEIRA, Márcia Silva de; MAMERI, Silvana Ferracciú. Quando o Morro vira Parque: elementos para entendimento do cotidiano e da vida social nos bairros de Nova Descoberta e Mãe Luíza, em Natal/RN. In: PEIXOTO, Elane Ribeiro; DERNTL, Maria Fernanda; PALAZZO, Pedro Paulo; TREVISAN, Ricardo (Orgs.). Tempos e escalas da cidade e do urbanismo: Anais do XIII Seminário de História da Cidade e do Urbanismo. Brasília, DF: Universidade Brasília- Faculdade de Arquitetura e Urbanismo, 2014. Disponível em: <http://www.shcu2014.com.br/content/quando-morro-vira-parqueelementos-entendimento-do-cotidiano-e-da-vida-social-nos-bairros>.

PAIVA, Ilana Lemos de; SOUZA, Candida de; VALENÇA, Daniel Araújo; ARAÚJO, Annamaria (org.). Direitos humanos e práxis: experiências do $\mathrm{CRDH} / \mathrm{RN}$. Natal: EDUFRN, 2015.

PEREIRA, Sumaya Saady Mohry \& OLIVEIRA, Assis da Costa. Rede Nacional das Assessorias Jurídicas universitárias: história, teoria e desafios. In UFG. Revista da Faculdade de Direito da UFG. Goiania: KELPS, V.33, N.1, jan./jun. 2009, pp.152-166. 
PIRES JUNIOR, Paulo Abrão; TORELLY, Marcelo (orgs). Assessoria jurídica popular: leituras fundamentais e novos debates. Porto Alegre: EdiPUCRS, 2009.

QUIJANO, Aníbal. Dom Quixote e os moinhos de vento na América Latina. Revista de Cultura de la Biblioteca Nacional del Perú, Lima, n. 10, 2005.

Colonialidade do poder, eurocentrismo e América Latina. in: LANDER, Edgardo

(org.). A colonialidade do saber: eurocentrismo e ciências sociais. Perspectivas latinoamericanas. Ciudad Autónoma de Buenos Aires: CLACSO, 2005. p.227-278. (Colección Sur Sur).

REFORMA AGRÁRIA EM DADOS. Disponível em $<$ http://www.reformaagrariaemdados.org.br/realidade/i-estrutura-fundi\%C3\%A1ria>. Acesso: 30 abr.2016.

RENAP. Cadernos RENAP. Online, n.6, 2005. Disponível em <http://www.renap.org.br>. Acesso: 12 abr. 2016.

RIBAS, Luiz Otávio. Assessoria jurídica popular universitária e direitos humanos: o diálogo emancipatório entre estudantes e movimentos sociais (1988-2008). Monografia de Especialização na Universidade Federal do Rio Grande do Sul.

RIBEIRO, Issac. Reitor da UnB faz palestra na UFRN nesta sexta-feira. Notícias. 25 set. 2009. Online. Disponível em: < http://www.isaacribeiro.com.br/2009/09/25/reitor-daunb-faz-palestra-na-ufrn-nesta-sexta-feira/>. Acesso: 13 abr. 2016.

SÁ E SILVA, Fábio Costa Morais de. É possível, mas agora não: a democratização da justiça no cotidiano dos advogados populares. In: SÁ E SILVA, Fábio; LOPEZ, Felix Garcia; PIRES, Roberto Rocha C. Estado, instituições e democracia: democracia. Brasília: Instituto de Pesquisa Econômica Aplicada, 2010. (Série Eixos Estratégicos do Desenvolvimento Brasileiro; Fortalecimento do Estado, das Instituições e da Democracia; v. 2).

SÁ E SILVA, Fábio Costa Morais de. Ensino jurídico, um tesouro a descobrir: a construção de alternativas pedagógicas e metodológicas a partir da reforma do ensino jurídico (e jurídico-penal). 2007. 215 f. Dissertação (mestrado em Direito) - Faculdade de Direito, Universidade de Brasília, Brasília, 2007.

SÁ E SILVA, Fábio de. Uma escola cheia de vida. 19/10/2015. Disponível em $<$ http://odireitoachadonarua.blogspot.com.br/2015/10/uma-escola-cheia-de-vidafabio-desa-e.html>. Acesso: 23 jul. 2016.

SADEK, Maria Tereza. O sistema de justiça. In: SADEK, Maria Tereza et al. (org.). 0 sistema de justiça. Rio de Janeiro: Centro Edelstein de Pesquisas Sociais, 2010.

SÁNCHEZ VÁSQUEZ, Adolfo. Filosofia da práxis.Trad. María Encarnación Moya. 2. ed. Buenos Aires: Consejo Latinoamericano de Ciencias Sociales; São Paulo: Expressão Popular, 2011. (Pensamento Latino-Americano). 
SANT'ANNA, Alayde. Por uma teoria Jurídica da Libertação. In: SOUSA JUNIOR, José Geraldo (org). O direito achado na rua. Brasília: Ed. UnB, 1987. p.31-33. (O Direito Achado na Rua, v. 1).

SANTOS, Boaventura de Sousa. Crítica à razão indolente: contra o desperdício da experiência. São Paulo: Cortez, 2000.

(org.). Democratizar a democracia: os caminhos da democracia participativa. Rio de Janeiro: Civilização Brasileira, 2002.

Poderá o direito ser emancipatório? Revista Crítica de Ciências Sociais, Coimbra, n. 65, p. 35, maio, 2003.

Cortez, 2011.

Para uma revolução democrática da justiça. 3. ed. rev. e ampl. São Paulo:

Sociología jurídica crítica: para un nuevo sentido común em el derecho. Trad. Carlos Lema Añón. Madrid: Trotta; Bogotá: ILSA, 2009. (Estructuras y processos).

O direito dos oprimidos. Coimbra: Almedina, 2014.

Cortez, 2006

A gramática do tempo: para uma nova cultura política. 2. ed. São Paulo:

Sociologia na primeira pessoa: fazendo pesquisa nas favelas do Rio de Janeiro. Brasília: Revista da Ordem dos Advogados do Brasil, n. 49, p. 39-79, 1988.

SAULE JÚNIOR, Nelson et al. Pesquisa Organismos Universitários de Direitos Humanos. São Paulo, 2015.

SAVIANI, Dermeval; DUARTE, Newton (Orgs.). Pedagogia histórico-crítica e luta de classes na educação escolar. Campinas: Autores Associados, 2012.

SEGATO, Rita Laura. La nación y sus otros: raza, etnicidad y diversidad religiosa en tiempos de políticas de la identidad. Buenos Aires: Prometeo Libros, 2007.

Antropologia e Direitos Humanos: Alteridade e Ética no Movimento de Expansão dos Direitos Universais. Mana, 12, v.1,207-236.

Alteridades históricas/identidades políticas: uma crítica a las certezas del pluralismo global. Brasília: [Universidade de Brasília], 1998. (Antropologia, 234).

SERRANO, Rossana Maria Souto Maior. Conceitos de extensão universitária: um diálogo com Paulo Freire. 2011. Disponível em: <http://www.prac.ufpb.br/copac/extelar/atividades/discussao/artigos/conceitos_de_exten sao_universitaria.pdf>. Acesso: 28 jul. 2016.

SILVA, Ana Tereza Reis da (Org.). Leituras críticas em educação e direitos humanos. Brasília: Liber Livro, 2014. 
SILVA, Antônio Fernando Gouvêa da. A busca do tema gerador na práxis da educação popular: metodologia e sistematização de experiências coletivas populares. Curitiba: Gráfica Popular; Cefuria, 2005.

SOUSA JÚNIOR, José Geraldo de. Movimentos sociais - emergência de novos sujeitos: o sujeito coletivo de direito. In: SOUTO, Cláudio; FALCÃO, Joaquim (org.). Sociologia e direito. 2. ed. São Paulo: Pioneira, 1999.

Sociologia jurídica: condições sociais e possibilidades teóricas. Porto Alegre: Sergio Antonio Fabris, 2002.

; et al. Observar a justiça: pressupostos para a criação de um observatório da justiça brasileira. Brasília: Ministério da Justiça; PNUD, 2009 (Série Pensando o Direito, v. 15).

. Por uma concepção alargada de Acesso à Justiça. Revista Jurídica, Brasília, v. 10, n. 90, Edição Especial, abr.-/mai. 2008. Disponível em: <http://www.planalto.gov.br/ccivil_03/revista/Rev_90/Artigos/PDF/JoseGeraldo_Rev90.PD F>. Acesso: 23 jun. 2015.

Fabris, 2011.

. Direito como liberdade: O Direito Achado na Rua. Porto Alegre: Sergio Antonio

O Direito Achado na Rua: concepção e prática. Rio de Janeiro: Lumen Juris, 2015 (Direito Vivo, v. 2). Rua, v. 1).

(Org.) O Direito Achado na Rua. Brasília: Ed. UnB, 1987. (O Direito Achado na

; AGUIAR, Roberto (orgs.). Introdução crítica ao direito do trabalho. Brasília: Ed. UnB, 1993. (O Direito Achado na Rua, v. 2).

; APOSTOLOVA, Bistra; FONSECA, Lívia Gimenes Dias da (orgs.). Introdução crítica ao direito das mulheres. Brasília: CEAD/FUB, 2011. (O Direito Achado na Rua, v. 5).

; COSTA, Alexandre Bernardino; MAIA FILHO, Mamede Said (Org.). A prática jurídica na UnB: reconhecer para emancipar. Brasília: UnB, 2007. (Prática Jurídica, v. 1).

; COSTA, Alexandre Bernardino (org.). Direito à memória e à moradia: realização de direitos humanos pelo protagonismo social da comunidade do Acampamento Telebrasília. Brasília: Universidade de Brasília, [s/d].

; SOUSA, Nair Heloisa Bicalho de; SANT'ANNA, Alayde Avelar Freire; ROMÃO, José Eduardo Elias; SANTANA, Marilson dos Santos; CÔRTES, Sara da Nova Quadros. Educando para os direitos humanos: pautas pedagógicas para a cidadania na universidade. Porto Alegre: Síntese, 2004. 
SOUSA, Nair Heloisa Bicalho de; COSTA, Alexandre Bernardino; FONSECA, Lívia Gimenes da; BICALHO, Mariana de Faria. O Direito Achado na Rua: 25 anos de experiência de extensão universitária. Participação: Revista do Decanato de Extensão da Universidade de Brasília, Brasília, ano 10, n. 18, dez. 2010. p. 43-53.

SOUZA, João Rodrigo Costa de. A produção audiovisual do \#foramicarla: características da apropriação do vídeo nos movimentos sociais em rede. 122 fl. 2014. Dissertação (Mestrado em Comunicação Social) - Departamento de Comunicação Social, Universidade Federal do Rio Grande do Norte, Natal, 2014.

SUNG, Jung Mo. Prefácio. In: HINKELAMMERT, Franz. Mercado versus direitos humanos. São Paulo: Paulus, 2014. (Novos caminhos da teologia). p. 5-11.

TAVARES, Ana Cláudia Diogo. Os nós da Rede: Concepções e atuação do(a) advogado(a) popular sobre os conflitos sócio-jurídicos no estado do Rio de Janeiro. Dissertação de Mestrado. Niterói-RJ: UFF, 2007.

TONET, Ivo. Educação contra o capital. 2. ed. rev. São Paulo: Instituto Lukács, 2012.

TRINDADE, Hélgio. O discurso da crise e a reforma universitaria necessária da universidade brasileira. In: GENTILI, Pablo (Org.). Las universidades en América Latina: ¿reformadas o alteradas?. La cosmética del poder . Buenos Aires: CLACSO, 2003. p.161 a 180.

UNIVERSIDADE FEDERAL DO RIO GRANDE DO NORTE. Dispõe sobre as Normas que Regulamentam as Ações de Extensão Universitária na Universidade Federal do Rio Grande do Norte - UFRN. Resolução no 053/2008 - Conselho de Ensino, Pesquisa e Extensão - CONSEPE, de 15 de abril de 2008. Disponível em: http://www.proex.ufrn.br/documentos/documento?id=161847549. Acesso em 28 de janeiro de 2016.

WALSH, Catherine. Interculturalidad, plurinacionalidad y decolonialidad: las insurgências político-epistémicas de refundar el Estado. Tabula Rasa, Bogotá, n.9, p.131-152, jul./dez. 2008.

Interculturalidad y Colonialidad del Poder: un pensamiento y posicionamiento otro desde la diferencia colonial. CASTRO-GÓMEZ, Santiago; GROSFOGUEL, Ramón. El giro decolonial: reflexiones para una diversidad epistémica más allá del capitalismo global. Bogotá: Siglo del Hombre Editores; Universidad Central, Instituto de Estudios Sociales Contemporáneos y Pontificia Universidad Javeriana, Instituto Pensar, 2007. p.47-62.

WARAT, Luiz Alberto. Introdução Geral ao Direito. v. I: Interpretação da lei; temas para uma reformulação. Porto Alegre: Sergio Antonio Fabris, 1994.

WOLKMER, Antônio Carlos (org.). Direitos humanos e filosofia jurídica na américa latina. Rio de Janeiro: Lumen Juris, 2004. 


\section{ANEXO A - NOTA DO PROGRAMA MOTYRUM SOBRE A MUDANÇA DE NOME ${ }^{108}$}

"Não há paz, quebram até as flores." 109

"E de guerra em paz

De paz em guerra

Todo o povo dessa terra

Quando pode cantar

Canta de dor"

Os homens e as mulheres se fazem sujeitos ao pronunciar o mundo, essa pronúncia se dá através da palavra maciça que é práxis, e, por isso, transformadora. A existência humana não se faz no silêncio, ao contrário, se faz na palavra que pronuncia o mundo, e que, ao ser pronunciado, volta aos pronunciantes, dessa vez, problematizado e assim exige uma nova pronúncia. A palavra, portanto, não é só palavra. A palavra é ação, é reflexão. É pronunciando o mundo que o homem e a mulher se fazem históricos, vivem o mundo não como coisas, mas como sujeitos que transformam o mundo quando o problematizam e agem. Portanto, dizer o mundo, pronunciá-lo, não deve ser privilégio de alguns poucos, mas sim direito de toda a humanidade.

Desse modo, dar nome às coisas toma um significado ainda mais forte. Um nome não é apenas som ou grafia, ele carrega consigo concepções de mundo, opções políticas, traz cultura, identidade. Um nome nunca será capaz de indicar a essência da coisa e nem de dizer a coisa em abstrato, pois a coisa só tem sentido na proximidade com os homens e mulheres.

108 Texto publicado originalmente aos 13 de março de 2013 no blogue do Centro Acadêmico Amaro Cavalcanti, sub-intitulado "Recanto Virtual do CA de Direito da Universidade Federal do Rio Grande do Norte - Campus Natal”. Conferir: MOTYRUM. Nota do Programa Motyrum sobre a mudança de nome. [on-line]. Disponível em: <https://amarocavalcanti.wordpress.com/2013/03/13/nota-do-programa-motyrumsobre-a-mudanca-de-nome/>. Acesso: 22 ago. 2015.

109 Nota elaborada pela pesquisadora: no texto original, não são indicadas as autorias dos dois trechos que abrem o texto. Durante a pesquisa, e em diálogo com as e os integrantes do projeto, foram identificadas as referências originárias, que, nessa oportunidade, são reproduzidas. O primeiro trecho, "Não há paz, quebram até as flores", é uma citação utilizada como epígrafe na obra "Filosofia da Libertação", de Enrique Dussel. Segundo o filósofo argentino, radicado no México, trata-se de uma fala realizada por sua filha Suzana quando a criança tinha 9 anos (Conferir: DUSSEL, Enrique. Filosofia da libertação na América Latina. São Paulo: Loyola; Piracicaba: Unimep, [s.d]. p.5. Coleção Reflexão Latino-americana, 3 - I). Desta mesma epígrafe, é extraído o poema que encerra o manifesto das e dos estudantes. O segundo trecho foi extraído da canção "Canto Das Três Raças", composta por Mauro Duarte e Paulo César Pinheiro, e eternizada na voz e interpretação de Clara Nunes. A música é uma expressão musicada, em samba, sobre a mestiçagem na formação do Brasil e ganhou projeção com o álbum, de mesmo título, da cantora (Conferir: Clara Nunes. LP. Canto das três raças. 1976. ODEON. Brasil). 
Nomear um coletivo, portanto, não é mera exigência estética, está relacionado com a identidade do grupo, com a sua ação. Por isso, os homens e mulheres que vem construindo conjuntamente o Programa de Educação Popular em Direitos Humanos Lições de Cidadania sentiram a necessidade de dar uma nova pronúncia ao coletivo. "Lições de Cidadania" já não é o nome que identifica a nossa práxis e, por isso, não é suficiente para a construção de nossa identidade.

O nosso coletivo nasceu como um meio de combate às opressões no mundo, e tem o objetivo de transformar a universidade e o saber produzido por ela em um instrumento dos oprimidos e das oprimidas, pois fazemos a opção política pelos esfarrapados e esfarrapadas do mundo, que têm sua palavra silenciada.

Embora o termo cidadania possa ser ressignificado, como Augusto Boal busca fazer em suas obras, é preciso fazer um contorcionismo hermenêutico para justificar o "Lições" de Cidadania de uma maneira progressista e libertadora. O nome do programa vinha representando o aspecto mais tradicional do termo, trazendo a ideia bancária de que alguém ensina lições de como ser um bom cidadão ou como tornar-se um cidadão capacitado para outrem, diferente da construção coletiva de novos saberes que o programa entende como pressuposto fundamental para uma educação libertadora. A própria ideia de Lição de cidadania já remete que só é cidadão aquele que aprende a ser e que, portanto há cidadãos e não-cidadãos aqueles que não se adequaram às normas cívicas.

O Programa Lições de Cidadania tem avançado muito nos últimos anos: ampliou seus campos de atuação; conseguiu acolher estudantes e professores de diversos cursos; conta com a participação ativa de 6 advogados que passaram pela extensão popular; tem extensionistas ocupando diversos espaços críticos e atuando diretamente com os movimentos sociais. O programa mudou, avançou, cresceu em pensamento e atuação critica. Mas o nome continuava. O nome e o símbolo - uma família heterossexual, formada por pai, mãe e filho - reforçando ainda mais a descontextualização entre as ações que o programa vem desenvolvendo e o nome com o qual se apresentava.

Somos latino-americanas e latino-americanos e tivemos nosso direito de pronunciar o mundo negado por processos encobridores que remontam à invasão de nosso continente até aos regimes totalitários apoiados pelo imperialismo em nome da "Democracia". Somos ainda Carlos Marighella, Juliano Siqueira, Dermi Azevedo, Mailde Pinto, Hélio Vasconcelos, Gregório Bezerra, Maria Laly, Maria Diva, Nivaldo Monte, Frei 
Tito, Mery Medeiros, Sabino Gentilli, Clara Camarão, Marcos Guerra, Aton Fon, Zumbi, os heróis e heroínas potiguares de 23 de novembro de 1935, somos xs militantes por um mundo mais justo e xs oprimidxs que a história teve a ousadia de encobrir os nomes. Somos San Martí, Simon Bolivar, Tapuias, Potyguaras, Guaranis.

Por isso precisávamos de um nome, de uma identidade, de uma palavra popular, feminista, negra, indígena, da juventude, dos oprimidos, dos condenados da terra, condenados do mundo e da história, que indicasse nossa opção lúcida e consciente pelos explorados e exploradas, pela libertação das correntes opressoras. Assim, escolhemos um novo nome que simboliza o nosso comprometimento com a luta histórica dos povos que tiveram sua identidade roubada, assim como ainda ocorre hoje em todos os espaços em que atuamos. Favelas, Campos, Presídios, comunidades indígenas, etc. Escolhemos um nome que significa mais que a união de pessoas, mais que um simples multirão. Talvez ainda mais que um "tamo junto". Escolhemos um nome que simboliza a resistência, a luta e a revolução.

Desse modo:

"Aos Povos do Terceiro Mundo que vencem o fratricídio

À mulher camponesa e proletária que suporta o uxoricídio

À juventude

Do mundo inteiro que e rebela contra o filicídio

Aos Anciões

sepultados vivos nos asilos."110

Somos, a partir de agora, Programa Motyrum de Educação Popular em Direitos Humanos

\footnotetext{
110 Da mesma forma que as demais citações do manifesto, o poema que o encerra não está referenciado no texto original. Contudo, sua extração teve como base a obra de filosofia de Enrique Dussel. Conferir: DUSSEL, Enrique. Filosofia da libertação na América Latina. São Paulo: Loyola; Piracicaba: Unimep, [s.d]. p.5. (Coleção Reflexão Latino-americana, 3 - I).
} 


\section{ANEXO B - ROTEIRO DE PERGUNTAS UTILIZADO NAS ENTREVISTAS}

*Nome, estudante/adv, em que período participa ou participou (se como estudante ou advogado), em que semestre do curso estava/está

\section{A - Identificação do projeto/EP}

1) Qual é a sua relação com o projeto/EP?

i. Estudante; Advogado/a; Colaborador/a; Outro - especificar

ii. Como essa relação foi estabelecida

iii. Qual foi sua primeira experiência no projeto?

2) Como você identifica o projeto? Você sabe o que são projetos de assessoria jurídica popular? Você acha q o EP se enquadra nelas?

i. Escritório popular?

ii. Assessoria jurídica popular?

iii. Outra opção

iv. Explorar denominações e conceitos

v. Por que tem esse nome (o que caracteriza "um" escritório popular, etc)?

3) O que é o Escritório Popular?

i. Objetivos

ii. Funções

iii. Estrutura - identificar recursos humanos e materiais

iv. Organização - identificar frentes, rotinas e fluxos de trabalho (como chegam e são encaminhadas as demandas, etc)

v. Atendimentos - identificar o objeto trabalhado pelo EP

4) Como surgiu o Escritório Popular?

i. Fundação

ii. Justificativa

iii. Organização inicial e outras características consideradas relevantes

5) Como é a atuação do EP? (Como chegam as demandas, qual o fluxo, etc?)

i. É interdisciplinar? 
ii. Relações estabelecidas (Fluxo)

iii. Público-alvo (Quem são os sujeitos com que o EP atua?)

6) Você conhece outras experiências semelhantes ao EP?

i. Quais?

ii. Há diálogo do EP com elas?

iii. Há semelhanças e/ou diferenças entre as experiências de EP?

7) O EP se relaciona com alguma instituição? Se SIM, identificar quais:

i. UFRN e outras universidades

ii. Instituições do sistema de justiça - judiciário, ministério público, defensoria pública, advocacia

iii. Outras instituições - identificar quais

iv. Grupos, organizações, etc - identificar quais

8) Quem são os principais sujeitos com que o EP atua? (perguntar como é essa atuação)

9) O EP se relaciona com o NPJ da UFRN e/ou de outra universidade?

i. Identificar como essa relação é estabelecida

ii. Identificar o objetivo/função dessa relação

iii. Identificar elementos de avaliação dessa relação estabelecida

\section{B - Concepções do e no projeto/EP}

10)O EP possui alguma/s concepção de direito que norteia a sua atuação? Qual? (Como enxerga o direito, como a atuação prática traz isso?)

11)O EP possui alguma/s concepção de direitos humanos que norteia a sua atuação? Qual?

12)Qual é a relação entre essas concepções e a visão de direito e de direitos humanos da sua formação (curricular) na graduação?

13) Você considera que o EP desempenha alguma função para a sua formação? Se SIM, qual seria essa função?

14) Você considera que o EP desempenha alguma função para a justiça? Se SIM, qual seria essa função? E se não, pq?

15) Você avalia que o EP atua, de alguma forma, para a democratização da justiça?

i. Explorar o que é considerado como "democratização da justiça" 
ii. Identificar elementos que são considerados como "indicadores" da função "democratizadora da justiça"

16)Que experiências/casos de atuação do EP você destacaria como as mais bem-sucedidas em relação à democratização da justiça? (limitar a 2) Por quê?

17)Como você avalia a atuação do $E P$ em relação às demandas de acesso à justiça de Natal e do RN?

18)Quais têm sido as principais limitações e lacunas do EP?

19)Qual a importância do EP para a sua formação? (E para a UFRN? E para o curso de direito? Extensão?)

20)Quais os principais aprendizados nessa trajetória de EP?

21)Quais os principais desafios colocados hoje para a atuação do EP?

*O que mais você gostaria de dizer sobre o EP? 


\section{ANEXO C - ROTEIRO UTILIZADO PARA O GRUPO FOCAL}

( ${ }^{\star}$ Frases utilizadas como elementos disparadores, retiradas das falas dos próprios sujeitos nas entrevistas individuais)

1) "Se o Núcleo de Prática Jurídica funcionasse, não precisaria existir o Escritório Popular".

2) "O Escritório Popular atua para a democratização da justiça porque existe uma escolha política pelos sujeitos com quem se trabalha".

3) "Nossa atuação cumpre um papel de escancarar, ir nas entranhas, a sensação é de que está tudo muito calmo no sistema de justiça, de que se está cumprindo a lei, o direito, mas na verdade, na prática, está todo mundo descumprindo a lei e a Constituição.

O que a gente leva de demanda não é nada revolucionário, a gente cumpre esse papel de constranger e de escancarar algumas hipocrisias e mexer um pouco nessa estrutura muito acomodada".

4) "Nós democratizamos quando ajudamos a politizar, no sentido favorável à gente, o Poder Judiciário. A gente advoga contra o Poder Judiciário, contra o Ministério Público".

5) "Nossa estratégia, para além de levar a voz de grupos e segmentos invisibilizados, é de ocupar espaços (na OAB, em Conselhos, etc)"

6) Somos sujeitos coletivos da advocacia popular/assessoria jurídica popular atuando com sujeitos coletivos de direitos.

7) Tabela com número de integrantes do projeto no decorrer de sua trajetória (problematização sobre o declínio do número de estudantes da graduação e desarticulação no último período).

8) Quais as estratégias de atuação do EP no Fora Micarla? E na Copa?

9) As ações coletivas foram todas perdidas, no caso da Copa, e mesmo assim a experiência é elencada como bem-sucedida de democratização da justiça. Por quê?

*As perguntas 7 e 8 não foram realizadas, por falta de tempo hábil, ocasionado por problemas na realização do grupo. 


\section{ANEXO D - ESTATUTO DO LIÇÕES DE CIDADANIA}

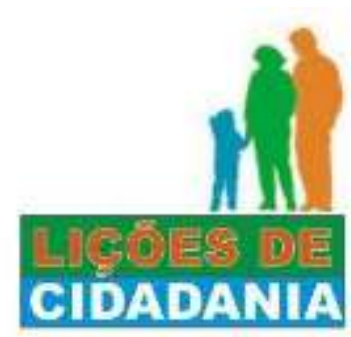

\section{UNIVERSIDADE FEDERAL DO RIO GRANDE DO NORTE CENTRO DE CIÊNCIAS SOCIAIS APLICADAS \\ Departamento de DiReito Público}

Projeto Lições de Cidadania

CoordenaçÃo-Geral

Ofício/Lições de Cidadania no

Natal, 29 de outubro de 2007

\section{ESTATUTO DO PROJETO DE EXTENSÃO LIÇÕES DE CIDADANIA}

Capítulo I

\section{DA CARACTERIZAÇÃO DA SEDE E FORO}

Art. 1ํ - O Projeto de Extensão Lições de Cidadania é uma sociedade civil, sem fins lucrativos e sem caráter político-partidário, direcionado para a construção de conhecimento, técnicas e extensão dentro da temática da educação jurídica popular, sob a orientação de professores de Direito da UFRN, congregando em seu quadro professores, pesquisadores, extensionistas e alunos da UFRN, acolhendo também outras pessoas interessadas em contribuir para a realização de seus objetivos.

Art. 2ํ - Para efeitos administrativos, o projeto "Lições de Cidadania" terá sua sede na sala localizado no Núcleo de Prática Jurídica da Universidade Federal do Rio Grande do Norte, em Natal-RN.

\section{Capítulo II}

\section{DAS FINALIDADES E OBJETIVOS}

Art. 3o - São finalidades e objetivos do projeto Lições de Cidadania:

a) levar a educação jurídica popular à comunidade como um veículo de transformação e de avanço sócio-político;

b) incentivar o estudo, o ensino, a pesquisa e a extensão no âmbito das áreas de Educação Jurídica Popular, na UFRN;

c) promover a divulgação e o intercâmbio de trabalhos científicos e sociais com outras áreas de Direito e de promoção social, no âmbito do estado do Rio Grande do Norte;

d) desenvolver o intercâmbio entre seus associados e pesquisadores filiados a outras sociedades científicas e sociais, nacionais e estrangeiras;

e) realizar reuniões periódicas, destinadas à atualização dos membros e à discussão de problemas de seus interesses; 
f) ressaltar a importância do compromisso social, buscando contribuir para que o conhecimento do curso de Direito ultrapasse a questão meramente técnica do aprendizado;

g) promover a cidadania e a educação jurídica popular em todos os âmbitos cabíveis.

Parágrafo Único. É vedado aos membros do projeto direcionar as atividades da entidade de forma a beneficiar partidos políticos ou grupos religiosos.

\section{Capítulo III}

\section{DOS MEMBROS \\ SEÇÃO I — CARACTERIZAÇÃO DOS MEMBROS}

Art. 4ํ- - Os membros do Projeto Lições de Cidadania estão distribuídos nas seguintes categorias:

a) alunos membros: Pesquisadores, Secretariado e Extensionistas.

b) professores membros - Orientadores;

c) membros honorários: os alunos e professores que já participaram em alguma edição anterior do projeto.

Art. 5 - Os alunos somente serão admitidos enquanto membros após seleção criteriosa, através de uma entrevista, promovida pelos secretariado do projeto, processo que deverá ocorrer anualmente.

$\S 1^{\circ}$ - A publicação de Edital para seleção deverá ser fixada no mínimo com uma semana antes da entrevista, em locais de domínio dos alunos.

$\S 2^{\circ}$ - Poderão ocorrer mais seleções, na medida das necessidades do projeto.

$\S 3^{\circ}$ - Os critérios serão decididos pelo secretariado de acordo com a necessidade do projeto.

Art. 6ำ - Os membros professores são admitidos em função de seu interesse e vontade de contribuir para com as finalidades do projeto.

\section{SEÇÃO II — DOS DIREITOS DOS MEMBROS}

Art. $7^{0}$ - São direitos do membro:

a) ter seu o mérito, dedicação e esforço no trabalho reconhecidos, bem como receber estímulo nesse sentido;

b) ser tratado com respeito e correção pelos demais membros, sendo respeitada sua integridade física e moral;

c) apresentar críticas e sugestões relativas ao projeto de pesquisa como um todo;

d) compartilhar o conhecimento, exercer a cidadania e atuar de forma responsável para a preservação do meio ambiente e para o crescimento econômico e social do país;

e) converter as discussões teóricas em práticas, na medida do possível;

f) ter acesso aos estatutos e regulamentos, bem como de todas as informações referentes os projeto Lições de Cidadania;

g) dispor do material e das instalações cedidas pelo projeto, devendo geri-las de modo a prosseguir o desenvolvimento das suas atividades;

h) ser informado com regularidade dos eventos e acontecimentos no âmbito do programa; 
i) participar de todos os programas do Lições de Cidadania para o qual foi selecionado;

j) direito de apoiar e ser apoiado em iniciativas dos membros que visem introduzir melhorias no funcionamento do projeto

I) ser recompensado, após a conclusão da sua pesquisa, com um certificado atestando todo o seu trabalho e valendo como horas a serem utilizadas no currículo.

\section{SEÇÃO III — DOS DEVERES DOS MEMBROS}

Art. 8 - - São deveres do membro:

a) respeitar, individual e coletivamente, este regulamento;

b) colaborar na gestão dos materiais e do convívio entre os membros;

c) conhecer o estatuto do projeto Lições de Cidadania;

d) zelar pelo bom nome e por divulgação do projeto;

e) buscar desenvolver uma forma de convívio harmoniosa, que auxilie no fortalecimento do grupo e na concretização dos objetivos;

f) empenhar-se ativamente na concretização das metas estabelecidas e no fortalecimento da Liga Jurídica;

g) ser assíduo e pontual nas reuniões do Projeto Lições de Cidadania, comparecendo às reuniões para as quais tenha sido devidamente convocado;

h) estimular o espírito democrático e pluralista, respeitador dos outros e das suas idéias, aberto ao diálogo e à livre troca de opiniões, julgando com espírito crítico e criativo o meio social em que se integram e de se empenhar na sua transformação progressiva;

i) justificar antecipadamente as faltas às reuniões do Projeto;

j) buscar estar informado, na medida do que for possível, acerca das iniciativas e das atividades desenvolvidas pela Liga Jurídica, como um todo;

k) contribuir para o crescimento do patrimônio material e moral do Projeto;

I) desempenhar as funções que the couberem junto ao Projeto, zelando pelo seu perfeito cumprimento;

m) fazer propostas de melhorias e trazer novas idéias que coadunem com as finalidades do projeto.

\section{SEÇÃO I V-DA PERDA DO TÍTULO DE MEMBRO}

Art. 9 - A perda do título de membro decorrerá:

a) da solicitação antecipada por parte do membro de seu desligamento, que deve ser apresentada por pedido escrito e justificada;

b) do não comparecimento às reuniões com o professor orientador ou com a coordenação por três vezes consecutivas, sem qualquer explicação por escrito ao grupo a qual faz parte;

c) por faltar mais de três a cada 10 reuniões;

d) por realizar ou omitir comportamento que contrarie os valores presentes no princípio da dignidade da pessoa humana, havendo a necessidade do aval da maioria absoluta dos membros do Projeto para o desligamento do membro;

e) desrespeitos às normas e aos princípios gerais deste estatuto. 
Capítulo IV

\section{DA ORGANIZAÇÃO}

Art. $10^{\circ}$ - O Projeto Lições de Cidadania tem sua gestão organizada em secretarias, as quais têm responsabilidades específicas, junto com a orientação do professor responsável pelo projeto.

Parágrafo Único - O organograma do Secretariado gestor tem fundamento na horizontalidade na disposição das inter-relações de suas unidades constitutivas, dos cargos, das funções e das atribuições de cada secretaria, formando um colegiado.

\section{Capítulo V}

\section{DAS COMPETÊNCIAS DO SECREATRIADO}

Art.11 - Compete aos secretários gerais:

a) Representar o projeto em todos os âmbitos, tanto na UFRN quanto fora;

b) Delegar funções e atividades;

c) Ser responsável pela organização e manutenção do projeto;

d) Promover a integração e cobrança da equipe

e) Promover a integração do projeto com o CAAC e com as pró-reitorias.

Art. 12 - Compete aos secretários administrativos:
a) Marcar as reuniões e organizar suas atas;
b) Procurar, preencher e conhecer os prazos dos editais;
c) Organizar o calendário;
d) Organizar os documentos e arquivos;
e) Preencher os editais lançados.

Art. 13 - Compete aos secretários acadêmicos:
a) Manter contato com os professores;
b) Promover os contatos institucionais do projeto;
c) Buscas de bibliografias e materiais científicos;
d) Prover as necessidades da pesquisa;
e) Ter o contato direto com as Pró-reitorias (extensão e pesquisa);
f) Preencher os editais lançados.

Art. 14 - Compete aos secretários financeiros:
a) Buscar financiamentos, patrocínios e editais;
b) Controlar o caixa;
c) Fazer compras;
d) Organizar os trâmites burocráticos de materiais;
e) Manter toda a logística necessária à pesquisa e principalmente à extensão.

Art. 15 - Compete aos secretários de comunicação:

a) Fazer a assessoria de imprensa do Projeto, mantendo contato com a imprensa escrita e mídia para divulgar as ações do projeto.

b) Responsáveis por toda a comunicação do projeto com participantes e demais alunos do curso de direito e outros cursos envolvidos; 
c) Atentar para sites, editais, congressos e atualizações pertinentes ao projeto.

d) Entrar em contato com instituições via e-mail;

e) Atualizar o site.

Art. 16 - Compete aos secretários da extensão:

a) Organizar a montagem de todo projeto de extensão;

b) Iniciar contato com as comunidades e fazer a ponte com a universidade;

c) Gerir a todos que irão participar da extensão;

d) Trabalhar em junto com os secretários financeiros, acadêmicos e gerais.

\section{Capítulo VII}

\section{DO PATRIMÔNIO}

Art. 17 - O patrimônio do projeto Lições de Cidadania será constituído pelos bens móveis e imóveis que o mesmo venha a possuir, e pelos recursos provenientes de:

a) taxas de cursos e outras promoções;

b) auxílios e subvenções;

c) legados transferidos da gestão anterior;

d) financiamentos;

e) outras fontes idôneas.

Art. 18 - Em caso de dissolução do Projeto, seu patrimônio reverterá em benefício a iniciativas do Curso de Direito da UFRN aos quais tenham finalidade compatível com do projeto Lições de Cidadania.

\section{Capítulo VIII}

\section{DAS DISPOSIÇÕES GERAIS}

Art. 19 - Este Estatuto poderá ser alterado por proposta do Secretariado ou de um grupo de membros, em Reunião Geral voltada para este fim.

Art. 20 - Os casos omissos neste Estatuto serão resolvidos pelo Secretariado do Projeto, através de reunião deliberativa.

Art. 21 - Os estudantes que participaram das antigas edições do Projeto Lições de Cidadania serão considerados membros honorários permanentes.

\section{DISPOSIÇÕES TRANSITÓRIAS}

Art. 22 - As disposições deste estatuto passarão a valer imediatamente após o aval da maioria dos membros do Projeto Lições de Cidadania. 